\title{
The years of alienation in Italy
}

DOI:

10.1007/978-3-030-15150-8

Link to publication record in Manchester Research Explorer

\section{Citation for published version (APA):}

Diazzi, A., \& Sforza Tarabochia, A. (Eds.) (2019). The years of alienation in Italy: factory and asylum between the economic miracle and the years of lead. Palgrave Macmillan Ltd. https://doi.org/10.1007/978-3-030-15150-8

\section{Citing this paper}

Please note that where the full-text provided on Manchester Research Explorer is the Author Accepted Manuscript or Proof version this may differ from the final Published version. If citing, it is advised that you check and use the publisher's definitive version.

\section{General rights}

Copyright and moral rights for the publications made accessible in the Research Explorer are retained by the authors and/or other copyright owners and it is a condition of accessing publications that users recognise and abide by the legal requirements associated with these rights.

\section{Takedown policy}

If you believe that this document breaches copyright please refer to the University of Manchester's Takedown Procedures [http://man.ac.uk/04Y6Bo] or contact uml.scholarlycommunications@manchester.ac.uk providing relevant details, so we can investigate your claim.

\section{OPEN ACCESS}




\section{The Years of Alienation in Italy}

Factory and Asylum Between the Economic Miracle and the Years of Lead

\section{Edited by Alessandra Diazzi Alvise Sforza Tarabochia}


The Years of Alienation in Italy 
Alessandra Diazzi • Alvise Sforza Tarabochia Editors

\section{The Years of \\ Alienation in Italy}

Factory and Asylum Between the Economic Miracle and the Years of Lead

palgrave
macmillan 


\section{Editors}

Alessandra Diazzi

School of Arts, Languages and

Cultures

University of Manchester

Manchester, UK

\author{
Alvise Sforza Tarabochia \\ Department of Modern Languages \\ School of European Culture and \\ Languages \\ University of Kent \\ Canterbury, UK
}

ISBN 978-3-030-15149-2
https://doi.org/10.1007/978-3-030-15150-8

(C) The Editor(s) (if applicable) and The Author(s) 2019

This work is subject to copyright. All rights are solely and exclusively licensed by the Publisher, whether the whole or part of the material is concerned, specifically the rights of translation, reprinting, reuse of illustrations, recitation, broadcasting, reproduction on microfilms or in any other physical way, and transmission or information storage and retrieval, electronic adaptation, computer software, or by similar or dissimilar methodology now known or hereafter developed.

The use of general descriptive names, registered names, trademarks, service marks, etc. in this publication does not imply, even in the absence of a specific statement, that such names are exempt from the relevant protective laws and regulations and therefore free for general use. The publisher, the authors and the editors are safe to assume that the advice and information in this book are believed to be true and accurate at the date of publication. Neither the publisher nor the authors or the editors give a warranty, express or implied, with respect to the material contained herein or for any errors or omissions that may have been made. The publisher remains neutral with regard to jurisdictional claims in published maps and institutional affiliations.

Cover illustration: estudio calamar

This Palgrave Macmillan imprint is published by the registered company Springer Nature Switzerland AG

The registered company address is: Gewerbestrasse 11, 6330 Cham, Switzerland 


\section{Preface}

The Years of Alienation in Italy project first took shape in 2014, when the editors of this volume began to discuss the possibility of organizing a conference on the cultural representations of the notion of alienation in Italy. The initial idea was to establish a dialogue among scholars who would explore, from an interdisciplinary perspective, the social and psychological implications of the concept in question. Our, and our speakers', goal was twofold: first, to tackle the notion of alienation in spatial terms, by examining the way in which literary and cinematic depictions of the factory and the asylum frequently blurred the dividing line between industrial alienation and clinical madness; secondly, to investigate the specificities of an Italian approach to alienation by interpreting the ubiquitous presence of the term in social and cultural discourses, in the light of the country's troubled history in the 1960s and 1970s.

The project took a more concrete form in 2015 when a two-day workshop was cohosted by the University of Kent (May 15, 2015) and the University of Cambridge (May 22, 2015).

The volume that we have the pleasure to introduce here is inspired by this exchange and discussion, the focus of which it maintains-and expands. While the contributions collected in this book still aim to investigate the factory and the asylum as the concrete, spatial embodiment of the two theoretical meanings of alienation, at the same time they explore these meanings further and consider how the term in question was used in Italy at the time under consideration. The book includes Adriano Olivetti's effort to challenge the equivalence between factory and alienation, and the reception of this industrial revolution in the literary work of writers 
such as Ottiero Ottieri and Paolo Volponi, who actively contributed to the project; the relevance this notion had in Italian psychoanalysis, in both its mental and social meaning; the transformation of the architecture of mental health institutions according to the ongoing psychiatric revolution, and the employment of the medium of photography to record this process of reform in psychiatric health care; the paradigm of the camp employed in literature to express the widespread feeling of estrangement and dehumanization stemming from biopolitical forms of control over social deviation; and the way in which cinema and literature strongly criticized, or alternatively praised, the institutions of asylum and factory as spaces embodying ideals of order, care, and health.

Through this wide-ranging approach, The Years of Alienation in Italy for the first time provides an interdisciplinary overview of the political and cultural meaning(s) that alienation has taken in Italy. The volume also looks at the national context as a paradigmatic case study, given Italy's pioneering role in the revolution of mental health care and factories. The volume can therefore be read as a theoretical reflection on the concept of alienation in the context of national culture, across fictional and non-fictional representations. At the same time, the notion of alienation acts as an interpretative lens that is employed to highlight unexplored aspects of two crucial decades in Italian history. Completed during the fortieth anniversary of Basaglia's Law, this book also tackles the long-lasting debate on Italian asylums from a novel perspective, proposing to read the revolution in the light of a broader social, cultural, and above all political debate on personal freedom and social control, one that cannot be confined to the psychiatric field.

We hope that the interdisciplinary nature of this volume, its coverage of a crucial time in Italian history through a selection of cinematic and literary case studies, and its organization in independent chapters, will mean it is a helpful didactic aid at different levels in higher education, as well as an essential contribution for scholars in the field of Italian studies, comparative literature, cultural history, and cinema and media studies.

The editors of this volume wish to thank the Kent Institute for Advanced Studies in the Humanities at the University of Kent, the Italianist committee, and the Italian Department of the University of Cambridge, which generously supported the workshops held in 2015 .

We are grateful to Krista Bonello Rutter Giappone for her help in rendering into English some idiomatic Italian sentences; Giovanni Fancello for his help with the history of the Italian Communist Party; Alex 
Marlow-Mann for his insights into the history of Italian cinema; and Nicolò Morelli who kindly provided essential bibliographical material. We would also like to thank Shaun Vigil and Glenn Ramirez, our editors at Palgrave, for following this project so closely and kindly.

Manchester, UK

Canterbury, UK
Alessandra Diazzi

Alvise Sforza Tarabochia 


\section{Contents}

1 Introduction: Social and Mental Alienation in Italy Between the Economic Miracle and the Years of Lead

Alessandra Diazzi and Alvise Sforza Tarabochia

Part I Spaces of Alienation

2 Into the De/Construction of the Psychiatric Space Emanuela Sorbo

3 Doctor in Slaughter: Emilio De Rossignoli's Dialectic of Enlightenment Fabio Camilletti

4 Volponi-Ottieri-Olivetti and the Ills of Homo industrialis: Returning to a "Civiltà della natura" as a Questionable Antidote to the Urban-Industrial Malaise David Albert Best 
5 "Sentirsi Scorticati Vivi." The Theme of Alienation in Ottiero Ottieri's Works

Fabrizio Di Maio

6 Paolo Volponi's Memoriale: Industry Between Alienation and Utopia

Tiziano Toracca

Part III Psychoanalysis and Alienation

7 Alienation and Psychoanalysis: Some Notes on Italy in the Years of the Economic Miracle Alessandra Diazzi

8 Psychoanalysis in Milan in the Age of Dis-alienation: The Case of Elvio Fachinelli

Pietro Barbetta

9 From the Factory to the Asylum... and Back: A Lacanian Perspective on the Cinematic Representation of Alienation in Elio Petri's La classe operaia va in paradiso 173 Luca Di Gregorio

Part IV The Asylum

10 Manicomiche: Madness, Language and the Dismantling of the Asylum in Gianni Celati's Comiche Michele Ronchi Stefanati

11 Mental Social, and Visual Alienation in D'Alessandro's Photography

Alvise Sforza Tarabochia 
12 "L'alienato nella cella è libero." Mario Tobino Between Le libere donne di Magliano and Per le antiche scale Wissia Fiorucci

Index 


\section{Notes on Contributors}

Pietro Barbetta is Director of the Milanese Centre for Family Therapy and Professor of Psycho-Dynamic Theories at the University of Bergamo, Italy. In 2012 he was Visiting Professor at the Institute of Social Medicine at the Rio de Janeiro State University. Pietro is a certified trainer of psychotherapy and psychoanalysis and works for institutes and universities from different countries, including Italy, Switzerland, Argentina, Brazil, Colombia, Chile, the United States, France, England, Spain, Portugal, and Mexico.

David Albert Best has lectured on Italian language/literature at the universities of Cork, Ireland, St Andrews, UK, and Trinity College Dublin, Ireland, and on English language/translation at Naples Eastern University, Italy. Since 2011 he has been Maitre de conférences at the Université Libre de Bruxelles, Belgium, where he teaches and develops materials/ methodology in English for legal purposes and also researches on European legal terminology and translation. His ongoing research in Italian Studies derives from a keen interest in twentieth- and twenty-first-century literary depictions of rural-urban geography, agrarian/economic history, and migration/work.

Fabio Camilletti is Reader at the School of Modern Languages and Cultures, University of Warwick, UK. His main specialism is Gothic and Romantic culture from a European perspective. In recent years, he has also extensively published on twentieth-century Italian literature, including contributions on authors such as Carlo Levi, Gianni Celati, and Giorgio 
Bassani, as well as a monograph on Italian occulture in the 1960s (Italia Lunare: Gli anni Sessanta e l'occulto, 2018).

Alessandra Diazzi is Lecturer in Italian Studies at the University of Manchester, UK. In 2015 she was awarded a PhD in Italian Studies from the University of Cambridge, with a dissertation on the reception of psychoanalysis in Italian literature and culture in post-World War II Italy. She has published on contemporary Italian literature-Italo Calvino, Alberto Moravia, Giorgio Manganelli, and Ottiero Ottieri among others-and cinema (Gianni Amelio). She works primarily on the controversial relationship between psychoanalysis and impegno in Italy. She is currently working on her first monograph, provisionally entitled Psychoanalysis, Ideology, and Commitment in Italy: Edoardo Sanguineti, Ottiero Ottieri, Andrea Zanzotto.

Wissia Fiorucci is Modern Languages Coordinator at the University of Kent, UK. Her research focuses on representations of gender in twentiethand twenty-first-century Italian literature, and on magical realism. Her most recent publications include the article “A Woman's Loss of Imagination: Paola Masino's Magical Realism in Nascita e morte della Massaia" (Italian Culture 36 (2), 2018) and the book chapter "Gender Activism in Contemporary Italy" in Women and the Public Sphere in Modern and Contemporary Italy (2017) edited by Simona Storchi et al.

Luca Di Gregorio teaches at the Universities of Winchester and Southampton, UK. He has previously taught Italian language, literature, and cinema at the School of European Culture and Languages (SECL) of the University of Kent, where he also completed his PhD and gained the HEA Fellowship. His research interests include aesthetics, psychoanalysis, film studies, continental philosophy, and critical theory. Currently, he is working on his first monograph, provisionally entitled Aesthetics of the Real: Lacanian Theory and New Realist Trends in Postmillennial Italy

Fabrizio Di Maio studied in Rome and Paris. In 2010 he was awarded a PhD in Italian Studies from University of Rome II, Italy, and he is currently completing a second $\mathrm{PhD}$ in Modern Languages at the University of Birmingham, UK. He has worked at the University of Gabès, Tunisia, Joseph Fourier University, France, and Stendhal University, France. Since 2015, he has been Teaching Fellow at the University of Birmingham, 
UK. He has published monographs and articles on twentieth- and twentyfirst-century Italian literature, with a focus on the relations between history and literature.

Michele Ronchi Stefanati has been Professor Eduardo Saccone PhD Scholar in Italian Studies at University College Cork, Ireland, since 2013. Ronchi Stefanati graduated in Medieval and Humanistic Philology from the University of Bologna, Italy, in 2010 and obtained his MA in Italian Studies from the same university, with a thesis on Ariosto's Furioso. Besides renaissance literature, his research now focuses on contemporary Italian literature and political commitment, with particular reference to the work of Gianni Celati. In 2016 he organized the international conference Gianni Celati: Tradition, Translation, Rewriting with the participation of Gianni Celati.

Alvise Sforza Tarabochia is Lecturer in Italian at the University of Kent, UK. He graduated in Philosophy at the University of Trieste, Italy, in 2006 and obtained his PhD in Italian at the University of Kent in 2011. His research interests and publications focus on Italian contemporary biopolitical thought, Lacanian psychoanalysis and especially Italian visual culture and psychiatry. He has published a monograph on the theoretical implications of Basaglia's thought (Psychiatry, Subjectivity, Community: Franco Basaglia and Biopolitics, 2013) and more recently an article on the photobook Morive di classe (Italianist 38 (1), 2018), among several other works.

Emanuela Sorbo is an architect and Associate Professor of Architectural Restoration at the IUAV University of Venice, Venice, Italy. She is a member of the Board of the Società Italiana per il Restauro dell'Architettura (SIRA). Her published work focuses on the forms and techniques of the restoration of ruins, with particular attention to post-war reconstruction (Liliana Grassi e il recupero creativo della memoria storica, 2004 with M.A. Crippa), to restoration in the Vesuvius archaeological area (Architetti, architettura e città del Mediterraneo Antico, 2007 with C.G. Malacrino; Tra materia e memoria: Ercolano 1711-1961, 2014) and to the conservation of forgotten heritage (La memoria dell'oblio: Ex ospedale psichiatrico di Rovigo, 2017).

Tiziano Toracca is a visiting professor at Ghent University and he is post-doc fellow at the University of Turin. He graduated in Law and in Italian Language and Literature and holds a joint $\mathrm{PhD}$ in Italian Studies, 
Comparative Literature and Literary Studies (Perugia/Ghent 2017). He coordinated a Jean Monnet Project (I work therefore I Am European) and he worked as Research Fellow at the University of Rijeka. His research focuses on Italian contemporary fiction, Modernism and Neomodernism, Labour, and Literature. He is a member of the Center for European Modernism Studies and he is editor of Allegoria and L'ospite ingrato. He has published several book chapters in collected volumes, and articles and reviews on literary criticism and film. 


\section{List OF CONTRibutors}

Pietro Barbetta University of Bergamo, Bergamo, Italy

David Albert Best Free University of Brussels, Brussels, Belgium

Fabio Camilletti University of Warwick, Coventry, UK

Alessandra Diazzi University of Manchester, Manchester, UK

Wissia Fiorucci University of Kent, Canterbury, UK

Luca Di Gregorio University of Winchester, Winchester, UK University of Southampton, Southampton, UK

Fabrizio Di Maio University of Birmingham, Birmingham, UK

Michele Ronchi Stefanati University College Cork, Cork, Ireland

Alvise Sforza Tarabochia University of Kent, Canterbury, UK

Emanuela Sorbo IUAV University of Venice, Venice, Italy

Tiziano Toracca Ghent University, Ghent, Belgium

Università degli Studi di Torino, Turin, Italy 


\section{Introduction: Social and Mental Alienation in Italy Between the Economic Miracle and the Years of Lead}

Alessandra Diazzi and Alvise Sforza Tarabochia

In 1964 Lacan (1998, p. 210) famously exclaimed: "One has to admit that there is a lot of this alienation about nowadays." Although not always explicitly in the spotlight of political and cultural discourses, alienation seems to have been a ubiquitous presence that haunted Western society in the 1960s and 1970s. The purpose of this book is to explore, from an interdisciplinary perspective, this notion's political meaning and cultural representation in Italy during two fundamental decades, which we reassess here as the country's "age of alienation" (Murchland 1971) par excellence. Although this is a time in which alienation seemed to be the malady

\section{A. Diazzi $(\bowtie)$}

School of Arts, Languages and Cultures, University of Manchester, Manchester, UK

e-mail: alessandra.diazzi@manchester.ac.uk

\section{A. S. Tarabochia $(\bowtie)$}

Department of Modern Languages, School of European Culture and Languages, University of Kent, Canterbury, UK

e-mail: A.Sforza-Tarabochia@kent.ac.uk

(C) The Author(s) 2019

A. Diazzi, A. S. Tarabochia (eds.), The Years of Alienation in Italy, https://doi.org/10.1007/978-3-030-15150-8_1 
that, broadly speaking, affected capitalist countries, Italy is a particularly significant case study for cultural, political, and social reasons that we will clarify here.

Alienation is a term of ambiguous vagueness, an "atrocious word" that perfectly fits the definition of "panchreston" (Hardins 1956), meaning everything and nothing (Johnson 1973). One of the most extensive studies on the slippery concept of alienation, Johnson's Alienation: Concept, Term, and Meanings (1973), begins by highlighting the difficulties inherent in theoretically pigeonholing the concept.

Though exploring a more limited field of inquiry, both geographically and chronologically, this volume is grounded in the same awareness of dealing with an all-encompassing word, an umbrella term that has multifarious meanings. At the same time, we aim to challenge the view of alienation as an undefinable and loose concept, contributing to the definition of the notion, its uses, and its representation in literature and the arts. This volume thus reappraises, from an Italian perspective, the different meanings that the notion of alienation took on: a social condition of estrangement and discomfort caused by the capitalist system, a pathological state of mind, and an ontological condition of subjectivity.

Traditionally stemming from Marxism, the concept of alienation in its sociopolitical sense had to be radically revised according to the transformations brought about by the rise of the post-Fordist, post-industrialized, and consumerist society over the two decades in question. At the same time, alienation understood as a synonym of mental disorder came under critical focus. On the one hand, movements critical of psychiatry questioned its medical nature and accused it of being a cause of social and mental alienation rather than the solution that it claimed to be. On the other hand, psychoanalysis started to investigate alienation as a constitutive characteristic of subjectivity rather than as an ailment to be cured. In the two decades under scrutiny, these two notions of alienation, arguably at the apex of two independent histories, began to overlap and cross-contaminations were explored: social alienation as a cause of mental disorders, and the continuity between the ontological alienation of the subject and the social alienation caused by the capitalist order, to name but two. The Italian context stands out as the most receptive soil for a variegated debate on alienation, and this has contributed to elucidating the several shades of meaning that the notion encompasses, and has even revolutionized the understanding of such an ideologically bound term. This book focuses on two physical and metaphorical spaces that we believe embody in the most telling way these takes 
on the notion of alienation: the factory and the asylum. They enable us to reveal the movements of "dis-alienation," for want of a better term, that emerged in the 1960s and 1970s in these spaces. Although in the factory social alienation came to the fore as much as mental alienation emerged more clearly in the asylum, this book explores potential overlaps, such as the factory as a cause of mental alienation and the asylum as an instrument of capitalist social control. Certainly, there are many more institutional contexts of alienation that could be explored, starting with schools, universities, and prisons. As we will show in this introduction, however, asylums and factories are at the center of the social upheavals and struggles of the two decades that are analyzed in this book, and as much as they are the physical spaces where the battles were waged, they were also elevated so that they became metaphorical spaces embodying all forms of institutional power and class struggle.

\subsection{Social Alienation}

Although the concept of alienation has a variety of meanings and uses in different disciplines, within the social sciences the Marxist definition is certainly the most popular.

According to Marx, the condition of alienation corresponds with a feeling of estrangement (Entfremdung) from one's humanity as a result of stratification into social classes. Belonging to a social class as a passive and mechanistic part of the system means that the individual is deprived of selfdetermination and free will. This is a consequence of the capitalist mode of production, which transforms the worker into an economic entity whose activity is fully controlled by the bourgeoisie, who own the means of production. As a result, although workers are self-realized subjects, within the logic of production they are tools from which owners aim to extract the maximum surplus value. At the same time, the working class is alienated from the product of their labor, which is taken from the control of workers and buyers, being determined by the capitalist class. In sum, in Marxian terms alienation is a "state produced by the ravages of a particular economic system - viz, capitalism - which separated the individual from the products of his labour, from the process of work, from the fellowship of his mankind, and, ultimately, from himself" (Johnson 1973, p. 15).

According to Eco, in 1962, such a state of alienation "costituisce per l'uomo moderno una condizione come la mancanza di gravità per il pilota spaziale" (Eco 1997, p. 256), a condition of abnormality that is, 
however, inescapable within a certain-transformed-environment: the neo-capitalist and newly industrialized Italy of the economic boom.

When Eco wrote these words, Italy was enjoying the miracolo economico (economic miracle), a time of sudden and unexpected growth that transformed the country from a backward and mostly rural nation to one of the strongest economic powers in Europe. ${ }^{1}$ This time of euphoria created by the rapid economic development coincided, however, with an increased feeling of discomfort and estrangement. This was provoked by a set of concurrent factors: the gradual disappearance of the countryside and the homogenization of the Italian landscape, which led to the loss of Italy's local diversity; the uncontrolled expansion of urban centers and the new life in chaotic metropoles and their peripheries, which meant that people lost the reassuring sense of community (Ginsborg 1990, p. 296); and exhausting work shifts in factories and a change in collective habits, which moved towards a gradual privatization of life.

Although "the state had played an important role in stimulating rapid economic development, $[\ldots]$ it then defaulted on governing the social consequences" (Ginsborg 1990, p. 240). As a result, the economic boom was not adequately followed by social reforms or by the long overdue renovation of public services. After the initial excitement about the new and unexpected opportunities, Italian people discovered the dark side of the miracle. "Fordism (the automated mass production of consumer goods) and consumerism," from being "the twin gods of the age" (Ginsborg 1990, p. 213), turned into alienating forces that were felt to be gradually dehumanizing public and private life.

Resistance to modernization and industrialization, which were seen as oppressive-rather than liberating-forces, emerged as soon as Italy began to develop. One of the most paradigmatic examples of this tendency is Pierpaolo Pasolini, who, looking retrospectively at the great changes that Italy underwent in the 1960s, saw in this transformation the main reason for the widespread diffusion of forms of social and cultural alienation. Whereas social alienation was due to the gradual disappearance of rural Italy, to be replaced by major urban centers, cultural alienation should be seen, according to Pasolini, as the gradual loss of the preconsumerist model of culture, not yet contaminated by popular products belonging to so-called low-brow culture. Although, in sum, Pasolini did not provide a systematic theory of alienation, the collective trauma to which he refers, a world from which fireflies gradually disappear (Pasolini 1975), certainly entails a view of the economic boom as an alienating process, which takes 
people away from their most authentic self and from the nation's shared past. Likewise, the concept of mutazione antropologica (1974) implies an idea of collective - and unredeemable-alienation, in that "come polli d'allevamento, gli italiani hanno indi accettato la nuova sacralità, non nominata, della merce e del suo consumo" (Pasolini 1999, p. 402).

Clearly, the resistance to modernity-conceived as an alienating condition-that can be found in the literature has political and ideological roots. From the early postwar years onward, Italian politics was undeniably affected by the Cold War. Although it was part of the Western bloc, and in spite of the influence the USA had on national economics, the Italian Communist Party (Partito Comunista Italiano, PCI) maintained primacy in several regional governments and local communities. As Stephen Gundle observes, "whereas most communist parties in Western Europe declined dramatically in the late 1940s and social democratic parties lost support in the 1950s, the PCI not only conserved a substantial membership but actually saw its electoral standing rise slowly yet continuously up until 1977" (Gundle 2000, p. 4). The PCI played the role of a sheer "cultural force" (Gundle 2000, p. 9), and it managed to impose its hegemony, disseminating throughout the country "the last great left-wing subculture in Western Europe" (Gundle 2000, p. 7).

Arguably, the PCI's cultural strength was a result of the long-term reaction to the 1956 crisis that, following Khrushchev's revelations and the repression of the Hungarian uprising, hit all European communist parties. In Italy the crisis served as an opportunity to promote Togliatti's "policentrism," the notion that every country should find its own way to socialism. The Italian way was to transform the PCI from a revolutionary to a mass party: a national-popular, Gramscian force, characterized by a leaning toward both intellectuals and social movements and investment in cultural policies, the intellettuale collettivo. This leaning, however, was felt to betray the original purpose of communism: to be a revolutionary doctrine of the working class. It attracted the dissent of, among others, Panzieri and Tronti, who founded the journal Quaderni Rossi, the cradle of operaismo, an autonomist Marxist theory focused on returning the working class to center stage, both from a practical and a theoretical standpoint. Operaismo and discontent about the PCI led to the creation of a strong, extrapolitical, and extraparliamentary left.

Consequently, Italian culture was split: on the one hand, it was in the mainstream largely affected by Americanization, and, on the other, it was shaped by a strong communist culture-both parliamentary and 
extraparliamentary—which, in different ways, resisted the "frivolous and fundamentally alienating capitalist culture" (Gundle 2000, p. 39) emanating from the USA.

This dysphoric reaction to the sudden process of modernization fed into the 1968 students' protests that raged in Italy and gave rise to the autunno caldo (hot autumn). In 1968 students from the main universities started to address their hatred of a society whose values were still heavily influenced by traditional and patriarchal culture. This movement marked the birth of a politicized youth, the protagonists of Italy's "ideological age," which was characterized by political struggle, social claims, activism of minority groups, and the demands of marginalized subjects. The students' protests for an extensive reform of education and, broadly speaking, the renovation of Italian society, influenced-and on some occasions directly triggered-a similar process of mobilization in the workplace. Workers joined the fight, calling for pay rises, more rights, and better conditions in factories, denouncing, in most cases, the rapid industrialization that led to appalling exploitation, especially for workers moving from the South to northern industries. Fueled by extraparliamentary left-wing groups born of operaismo (e.g. Lotta Continua, Potere Operaio), the public protests and revolts shaking Italy between 1968 and 1969 eventually celebrated, in 1970, one of the workers' greatest successes, the statuto dei lavoratori: "equal wage increases were to be granted to all, the forty-hour week was to be introduced in the course of the following three years, and special concessions were made to apprentices and worker-students. The trade unions also won the right to organize mass assemblies at the workplace" (Ginsborg 1990, p. 318). Despite such a significant victory, Italy's social unrest did not stop; conversely, it soon escalated into violence and outright acts of terrorism. Reactionary neo-fascist groups, allegedly steered by secret services and possibly in connection with the CIA (see Cento Bull 2007), deployed what The Observer called a "strategy of tension": subversive terrorist acts aimed at destabilizing the Italian government and ultimately prompting the return of an authoritarian, anti-Communist, regime. The first of such events orchestrated by the neo-fascists, the massacre of Piazza Fontana, inaugurated a season of unprecedented extreme left- and right-wing violence that shook the country until the early 1980s, the anni di piombo. 


\subsubsection{Alienation, Society, and Literature: Theoretical Perspectives}

A discussion of alienation as a direct consequence of the dramatic changes that Italy underwent between the 1960s and 1970s did not explicitly feature in the coeval political debate; nor was it a notion with which Italian Marxism engaged explicitly (Piccone 1983). However, the collective need to discuss, represent, and denounce alienation as a contemporary phenomenon found in literature the privileged site of elaboration. As Chirumbolo and Moroni (2010, p. 8) observe, "the dramatic metamorphosis of Italian society $[. .$.$] had such a remarkable impact on literature$ and the arts that the rise and success of new aesthetic phenomena [... have to be related to the renewal of Italian society in all its different facets." These "new aesthetic phenomena" included a notable interest in the notion of alienation, which turned into a literary theme and a stylistic device. Since the boom, in sum, alienation "has been a constant in Italian literature" (Peterson 2010, p. 5).

In the 1950s and 1960s, a well-defined literary trend-the letteratura del benessere (Pedullà 1968)—stemmed from the necessity to explore through narrative and storytelling the new age in which economic wealth and a contagious social discomfort went hand in hand. While Italians started enjoying an unexpected "easy life," writers engaged in a criticaland on some occasions overly polemical-representation of the boom, which was aimed at denouncing the alienating aspects of the alleged miracle. Such a sharp ideological stance against Italy's neo-capitalist society on the part of writers is a result of the specific features of the national "repubblica delle lettere." As Antonello observes, the literary dimension in Italy not only acts as a foundation of national identity but is also dominated by the paradigmatic figure of the "scrittore intellettuale," whose ubiquitous voice monopolizes the national cultural scene (Antonello 2012, p. 50). In the decades considered here, and in particular the 1960s, social and civil commitment in literature took the shape of an antimodern tendency expressed through representations of reality that portrayed the new lifestyle, urbanization, and industrialization as dehumanizing and estranging forces, rather than celebrating them as positive forms of progress. The attention that literature devoted to industrial society was fueled by the firsthand experience of the factory that many writers had-Fortini, Ottieri, Sinisgalli, and Volponi, to name but a few-being hired by the Italian entrepreneur Olivetti in his northern and southern factories. ${ }^{2}$ A visionary 
industrialist with a revolutionary view of the factory, Olivetti's greatest preoccupation was "evitare l'alienazione prodotta dalle fabbriche gigantesche, e dal distacco opprimente dalla natura" (Olivetti 1960, p. 108). In order to achieve this ideal, he believed the recruitment of intellectuals, artists, and writers- "non-industrial" figures-could help with revolutionary factory development. He believed that establishing a dialogue between engineers, technicians, and intellectuals would contribute to the development of an innovative understanding of the factory, transforming it into a "human space" and an inspiring community rather than an alienating institution. Such a close relationship between Italian writers and the industrial world in the 1950s certainly contributed to making 1960s Italian literature a site where this experience was elaborated upon. Literature, therefore, not only embodied the domain for a cultural reassessment of alienation, but also, and consequently, constituted a particularly appropriate lens through which to observe what alienazione meant in the Italian context.

In 1962 Moravia explicitly stated that alienation was a pervasive theme in coeval literature that writers could no longer ignore, being a widespread condition that was affecting Italian society as a whole:

Che cos'è l'alienazione? Secondo Marx, l'alienazione è il processo per cui l'uomo diventa estraneo a se stesso fino al punto di non riconoscere se stesso. L'operaio è alienato prima di tutto perché il prodotto del proprio lavoro non gli appartiene e poi perché egli non s'esprime attraverso quel lavoro in quanto il lavoro non lo riguarda in alcun modo. In termini più generali, diremmo che c'è alienazione ogni volta che l'uomo è adoperato come mezzo per raggiungere un fine che non è l'uomo stesso bensì qualche feticcio che può essere via via il denaro, il successo, il potere, l'efficienza, la produttività e via dicendo. [...] Stando così le cose, cioè essendo l'alienazione ossia la crisi del rapporto con la realtà, il fenomeno fondamentale del mondo moderno, non è affatto sorprendente che gli scrittori se ne occupino sia parlandone direttamente nei saggi, sia cercando di rappresentarlo nelle opere di narrativa. (Moravia 1964, pp. 377-379)

A cluster of writings dealing with the ideological implications of the notion, and offering a thorough examination of alienation as the novel "discontent" of Italian society, clearly demonstrates the impact of this concept on national literature. Turning literature into a tool capable of representing the feeling of alienation that dominated contemporary life was a priority in the theoretical debate on the direction that literatureand literary language-should take after the postwar neo-realist wave. 
In the early 1960s, the spreading "industrial disease" triggered an intense theoretical discussion about the most effective way(s) to convey the alienated state of the contemporary person and to denounce industry and industrialization as the main causes of this condition. Between 1961 and 1962, the literary review Il menabò and the magazine L'Espresso hosted a debate on literature and industrialization, which soon turned into a reflection on literature and alienation. ${ }^{3}$

The discussion began in 1961, when the fourth issue of Il menabò was devoted entirely to exploring the relationship between literature and industrial realities. More precisely, writers and intellectuals investigated the ways in which literature could (or could not) portray industry, asking themselves whether literary works might be capable of "redeeming the industrial world from its alien objectivity and help society as a whole formulate an emancipatory project that was rooted in the understanding of the present" (Bolongaro 2003, p. 40). As a result, the various contributions collected in Il menabò hypothesized if-and how-literature could give voice to the feeling of estrangement caused by the rapid and disturbing modernization of Italian society. One of the most interesting theses presented here is Vittorini's famous article "Industria e letteratura," in which he polemically addressed all the narratives that turned industrial society, and the factory itself, into fashionable topics, thereby limiting themselves to a realistic representation. For Vittorini, these works did not provide an effective portrayal of coeval social changes; nor were these texts able to shed light on the causes and consequences of the spreading of the "industrial illness." This could not be conveyed at the level of content, through naturalistic narrative techniques. On the contrary, Vittorini argued, only an alienated style, in terms of both language and storytelling, was a successful method for depicting the discomfort of the contemporary person:

Ad esempio i prodotti della cosiddetta école du regard, il cui contenuto sembra ignorare che esistano delle fabbriche, dei tecnici e degli operai, sono in effetti molto più a livello industriale, per il nuovo rapporto con la realtà che si configura nel loro linguaggio, di tutta la letteratura cosiddetta d'industria che prende le fabbriche per argomento. (Vittorini 1961, pp. 18-19)

In other words, according to Vittorini, the term "industry," in the phrase "literature and industry," should be replaced by the term "reality." The task of an effective "industrial literature" was to observe and depict con- 
temporary society as a whole, which constituted the only way to testify to the effects of industrialization and neo-capitalism in Italy. For Vittorini, alienation was a pervasive condition affecting any aspect of Italian life, and not a malady to be exclusively explored within the closed world of the factory. As a result, any literary approach that looked only at the factoryand the naturalistic approach in particular-would have coincided with a reactionary depiction of Italy's new alienating economic system, and therefore with its passive acceptance.

Gianni Scalia shared this conviction. Contributing to the debate on literature and industry, he wrote that the kind of literature that narrows its focus to the theme of factory and industrial work was doomed to describe, rather than challenge, the reality it portrays. As a result, for Scalia, industrial literature had to turn into a "literature of alienation" in order to effectively hold a cognitive and revolutionary power:

Il dato fondamentale del lavoro industriale è l'alienazione. Ed il tema dell'alienazione è alla base di ogni possibile attività letteraria conoscitiva (non rettorica $[$ sic $]$ e decorativa).

$[\ldots]$

L'alienazione assume aspetti sottili, complessi e difficili, di psicologia e di etica, che lo scrittore può contribuire a conoscere e a comunicare.

$[\ldots]$

Il compito di una letteratura contemporanea è, certo, quello di anticipare nella rappresentazione dell'alienazione industriale, il divenire della liberazione dall'alienazione industriale.

$[\ldots]$

La letteratura dell'industria non è un una letteratura 'industriale,' ma un compito conoscitivo e rappresentativo dell'alienazione industriale e della sua liberazione attraverso il legame con il comune potere di trasformare l'industria. (Scalia 1961, pp. 104-105, 108, 112)

Intervening in the debate, Eco seemed to agree with Scalia, in that he described alienation as the most visible effect of the transforming society of the boom and the natural condition of the contemporary person. In his own words:

Una condizione in cui imparare a muoversi e a individuare le nuove possibilità di autonomia, le direzioni di libertà possibile. Vivere nell'alienazione non vuol dire, peraltro, vivere accettando l'alienazione, ma vivere accettando una serie di rapporti che vengono tuttavia costantemente messi a fuoco da una 
intentio secunda che ci permette di vederli in trasparenza, di denunciarne le possibilità paralizzanti; rapporti da agire demistificandoli di continuo, senza che demistificarli voglia dire annullarli. (Eco 1997, p. 256)

At the same time, Eco pushed further, and somehow radicalized the view of how literature should approach the issue of alienation, proposing an experimental way in which to understand the pairing "literature and industrial society." According to Eco, writers and poets, through an estranging and novel use of language, had to develop new modes of expression that might be able to convey the condition of alienation that characterized industrial society. As Moroni observes, "for Eco [...] the task would be to denounce and demystify the consequences of alienation $[\ldots]$. In terms of artistic language, this task could be pursued by elaborating new formal structures that could respond actively to the alienating situation $[\ldots]$ provoking in the audience a sense of uneasiness with respect to the traditional view of the world" (Moroni et al. 2010, p. 80):

Accettate queste premesse si può allora iniziare un discorso sulla situazione di una letteratura che voglia rispondere all'esistenza di una società industriale, che si proponga di esprimere questa realtà, le sue possibilità e i suoi blocchi. Il poeta che, intravista la condizione di alienazione patita dall'uomo in una società tecnologica, tenta un discorso di descrizione e denuncia su questa situazione assumendo i modi di un linguaggio 'comune' ('comunicativo,' comprensibile a tutti) attraverso il quale espone il suo 'soggetto' (poniamo, il mondo operaio), pecca per generosità, ma commette in buona fede peccato di mistificazione. (Eco 1997, p. 270)

However, what Eco meant by "alienation" in his contribution was found to be problematic in a context in which the term was mostly intended with its ideologically acceptable meaning. The definition he provided for alienation was in fact broad and did not entail any explicit reference to a political understanding of the term: "Alienarsi-a-qualcosa vuole dire [...] rinunciare a se stesso per consegnarsi a un potere estraneo, farsi altro in qualcosa, e quindi non più agire nei confronti di qualcosa ma essere-agitoda qualcosa che non siamo più noi" (Eco 1997, p. 236). Without rejecting the Marxist meaning, Eco focused on the ontological and phenomenological aspects of alienation. For him, the term was to be understood in the Hegelian sense, as a state of perennial tension characterizing the relationship between the I and the world, the subject and the object: 
Questo tipo di alienazione $[\ldots]$ può essere indicato $[\ldots]$ come il problema che si pone al soggetto non appena esso produce un oggetto e gli si rivolge in un atto di intenzione per usarlo o semplicemente per considerarlo [...] il problema di qualsiasi essere umano col mondo delle cose che lo circonda. (Eco 1997, p. 241)

Intesa così, l'alienazione diventa però qualcosa che può essere risolta, e risolta attraverso una presa di coscienza e un'azione, ma mai risolta per sempre. Se un rapporto alienante è anche quello di due persone che si amano, ciascuna riducendosi alla rappresentazione che l'Altro ne dà, ed uniformandovisi, non si potrà più allora prevedere una civiltà in cui la messa in comune dei mezzi di produzione elimini completamente dalla dialettica della vita e dei rapporti umani il pericolo dell'alienazione. Chiaro che a questo punto la categoria dell'alienazione non definisce più soltanto una forma di relazione tra individui basata su una certa struttura della società, ma tutta una serie di rapporti intrattenuti tra uomo e uomo, uomo e oggetti, uomo e istituzioni, uomo e convenzioni sociali; uomo e universo mitico, uomo e linguaggio. (Eco 1997, pp. 242-243)

Eco therefore proposed a de-ideologization of the notion of alienation in the sense that, rather than focusing on it as a consequence of the capitalist mode of production, he mostly considered alienation as a form of dysfunctionality affecting people's relationships in contemporary society. This view of alienation-seemingly non-political-triggered Asor Rosa's polemical response. Eco's position was indeed read by the Italian critic as a passive acceptance of alienation and, consequently, of consumerist society, in which any attempt to resist this condition was perceived as absent:

[For Eco] l'alienazione diventa un fenomeno irrimediabile, permanente, ma al tempo stesso non tragico, anzi pressoché 'naturale,' e di conseguenza il modo di affrontarla si trasforma da un rovesciamento totale dell'essere sociale (rivoluzione) in una pratica delle condizioni possibili di liberazione parziale. Se ne può dedurre persino un mutamento nella figura professionale dello scrittore e dell'uomo di cultura: uno specialista dotato di particolari strumenti di conoscenza, la cui funzione, il cui 'mestiere' si esercita anche attraverso la rinuncia a cercare quelle risposte ultime che, proprio in quanto tali, sono paralizzanti $[\ldots]$ Un vento americano comincia a soffiare sulle patrie lettere. (Asor Rosa 1982, pp. 624-625)

Besides occupying center stage in the theoretical debate, alienation was at the same time a specter haunting literary works themselves, which became the laboratory to express and, on some occasions, try to overcome, the condition of alienation affecting contemporary society. 


\subsubsection{Industrial Literature and the New Avant-Garde}

The letteratura industriale or letteratura di fabbrica (industrial literature or literature of the factory) provided a particularly receptive soil in this respect. Although in its strictest sense the label encompasses a set of literary works revolving around factory work, industrial literature in Italy went well beyond thematic boundaries. Speaking of "literature and industry" in Italy does not exclusively mean referring to those literary works that revolved around the factory. On the contrary, the term "industry" in "literature and industry" is "something of a misnomer," as it refers to many different aspects of the new society of the miracle and especially to "modern capitalism and its consequences at an individual and social level, analysed in particular in terms of alienation" (Caesar 1996, p. 567).

Spreading in Italy since the late 1950s, when the economic miracle was peaking, this literary trend developed along two paths. Firstly, there is a set of narrative works that explicitly deal with factory-related themes and depict-through neo-realist and naturalistic modes of expression-the new urban reality. Second, poets tried to problematize this representation of industrial society, searching for an experimental style and innovative narrative techniques that could mimetically reproduce, on a formal level, the effects of industrialization and factory work on individuals.

The first trend gathers a set of "novels of the factory," which were meant to be read as sociological documents of the new industrial era. In order to do this, these narratives made blue-collar workers and exhausting shifts their privileged narrative themes, with the space of the factory suddenly taking center stage and becoming the ubiquitous protagonist. An early example of this thematic trend may be found as early as 1957, when Ottieri-one of its most prolific exponents-published Tempi stretti, which, as the title itself made abundantly clear, denounced the obsessions of industrial society: timed piecework, exhausting shifts, the inhumane pace of the factory, and the imperative of productivity. Marcovaldo Calvino's protagonist of the homonym book (1966) later regarded as a naive hero of children's literature, first appeared in L'Unità as the embodiment of the worker deprived of his identity and alienated by the new urban environment, which he regards as an unknown universe. ${ }^{4}$ Bianciardi also dealt with the themes of urbanization and industrialization in La vita agra (1962). Volponi pushed the representation of the estranging effects of industrial society on individuals even further, portraying in Memoriale (1962) the blurring line between the bluecollar worker's state of alienation in the factory and a condition of paranoia 
leading to clinical madness. As Guglielmi observed, as soon as the novel came out, "lo straordinario romanzo di Volponi si sviluppa secondo una doppia linea: per un verso, è la descrizione di un caso clinico, per un altro verso rappresenta la condizione dell'operaio nella fabbrica neocapitalistica. Alla reificazione industriale si sovrappone la paranoia" (Ferretti 1972, p. 44).

Published in the early years of the boom, these are just the most popular-and paradigmatic - examples of a new literary trend, although this list of "novels of industrialization" published in Italy in the 1960s is far from exhaustive. Levi, Sinisgalli, Mastronardi, Parise, Majorino, and many others also contributed to making the romanzo di fabbrica a popular genre on the editorial market, turning the new Italy of factories into a privileged narrative setting. ${ }^{5}$ Not surprisingly, several of these scrittori industriali were also those who, in the previous decade, had participated in Olivetti's project. What is potentially unexpected, however, is that their narratives bring to light the risks that are intrinsic to the process of de-alienation of the industrial dimension. The most exemplary cases in this respect are Ottieri and Volponi, who represent the "good factory" as an oppressive institution. Both Donnarumma all'assalto (1959) and the aforementioned Memoriale describe forms of global control on workers' lives through the company welfare system (welfare aziendale), which, while offering workers exceptional assistance and care, at the same time deprived them of the opportunity to protest against the industrial system, now seen as a source of wealth and health. In other words, Olivetti's utopia was affected by a more subtle and ambiguous form of alienation in that the "nanny factory" was perceived as a safe space, which impeded the development of political agency and class-consciousness.

The second literary trend that dealt extensively with alienation was Italy's new avant-garde poetry and, more precisely, the experimental production of I Novissimi and Il Gruppo 63. Compared to letteratura industriale in prose, the approach was, however, radically different: rejecting a content-related approach to the industrial world, poets were interested in seeking new forms to convey the estrangement of neo-capitalist society. Their aim was the creation of a revolution in style and language, capable of making the voice of the new alienated subject heard.

Alienation was already key in Sanguineti's Laborintus, which inaugurated, as early as 1956, the new avant-garde trend in poetry. Criticized by Zanzotto, who claimed the collection would have been of value only if it were considered a faithful record of an "esaurimento nervoso," Sanguineti 
replied that "effettivamente Laborintus si salvava nell'angolo indicato, ma con una non piccola correzione: e cioè che il cosiddetto 'esaurimento nervoso' che io tentavo di trascrivere sinceramente era poi un oggettivo 'esaurimento storico." Not just a simple literary dispute, Sanguineti's reply to Zanzotto provides a fundamental element to understand the relevance of alienation in Sanguineti's poetics. According to him, in fact, the "nervous breakdown" represented in the poem by means of language did not express a subjective neurosis but mirrored the alienating condition determined in the Western world by the capitalist economy and the bourgeois social system. The poet himself described his exordium as a descent into the "Palus Putredinis [...] dell'alienazione, con la speranza, che mi ostino a non ritenere illusoria, di uscirne poi veramente, attraversato il tutto, con le mani sporche, ma con il fango, anche, lasciato davvero alle spalle" (Balestrini et al. 2013, p. 545). Far from being an aspect of his first collection only, Sanguineti's early phase of production was characterized as a whole by the "intenzione poetica" of reproducing through language "uno stato 'oggettivo' di alienazione [...] uno straniamento sofferto con la coscienza dello straniamento" (Balestrini et al. 2013, p. 544). Alienation therefore took on, in Sanguineti's work and later on in the new avantgarde production, three different-but closely interwoven-meanings: a clinical one, referring to the nervous breakdown of the subject overwhelmed by life in neo-capitalist society; an ideological understanding of the term, intended in its Marxist sense; and the further meaning of alienation as estrangement, an aesthetic procedure designed to reproduce, through the distortion of language, the defamiliarized and uncanny perception of the world experienced by the alienated subject:

Perché quando nel Laborintus si parla, con preciso rigore, di 'alienazione,' si sommano insieme l'ovvio significato clinico [...] e quello diversamente tecnico, di Verfremdung, comprendente a sua volta sia il valore sociologicamente diagnostico del concetto marxista, sia quello derivatamente estetico ('straniamento') di marca brechtiana (mirabilmente ripreso, a non dire di altri, da Adorno). (Balestrini et al. 2013, pp. 543-544)

When in the early 1960s Giuliani gathered the five most promising poets of the new avant-garde in the collection I Novissimi (1961), he followed Sanguineti's path by explicitly situating the volume under the aegis of alienation. In the collection's introduction, which also reads as a manifesto, Giuliani clearly states that I Novissimi's main goal was to shape a 
new "lingua poetica" capable of "misurarsi con la vita contemporanea" (Giuliani 2003, p. 22). In order to do this, Giuliani argued, poets in their work enact what he explicitly defined as "dialettica dell'alienazione." This dialectic envisaged a conscious erasure (riduzione) of the subject, whose eclipse was seen as "l'ultima possibilità storica di esprimersi soggettivamente" (Giuliani 2003, p. 22). In the "years of alienation," in fact, the structured and unified lyrical I was no longer the carrier of a reliable worldview, given the condition of estrangement in which the self found itself immersed in contemporary society. The necessity of making the alienated subject the center of the poetical discourse therefore led to a "suspension of subjectivity - and of the 'subject' as a cognitive agency-in order to establish a more authentic approach to the world" (Chirumbolo and Moroni 2010, p. 9). A form of poetry that sided "dalla parte dell'oggetto" was in fact the only means that contemporary poets had to mimetically reproduce the subject's loss of freedom in capitalist society. However, it must be noted that the aim of this technique was not an idle representation of a state of alienation; rather, it ultimately tended towards the "recupero di quel medesimo io prima ridotto metodicamente" (Giuliani 2003, p. 22). Both Sanguineti and Giuliani therefore conceived literature as a crucial tool to critically portray the malady of modern society. At the same time, literature was seen as the instrument that, in artificially reproducing alienation, may have contributed to denouncing, and debunking, it.

At this stage, we can safely affirm that-during the 1960s and particularly in the early years of the boom-alienation as a style and a mode of expression gradually took the shape of an actual trend in Italian literature. Whereas literature was undeniably the artistic domain that, par excellence, was concerned with the issue of alienation and its representation, as Eugeni (2002, p. 49) rightly argues, "scarsa attenzione è venuta invece dal cinema." Indeed, Italy's most paradigmatic and widely known film of the boom, Risi's Il sorpasso (1962), focused mostly on the rising consumerist society and the "disease of desire" stemming from the new and unexpected wealthy life, rather than on the condition of alienation. Cortana, protagonist and victim of the miracle, is a slacker trickster travelling through Italy in his luxury car, rather than a worker alienated by urban life. Similarly, Gregoretti's Il pollo ruspante, one of the episodes of the collective film Ro.Go.Pa.G. (1963), represents the boom as a dangerous invasion of goods and commodities into the life of Italians, spoiled by rising Americanization. In this case as well, the urban and industrial dimension of the boom - with its alienating effects-is mostly neglected. 
It is worth mentioning, however, that although in the 1960s filmmakers did not concentrate on alienation as much as writers did, Antonioni's filmography constituted a notable exception. His trilogy of alienation, including L'avventura (1960), La notte (1961), and L'eclisse (1962), focused on the altered relationship between individuals and reality, and the I and the others, in contemporary society, with a particular focus on 'non-communicability' between subjects as an effect of the feeling of estrangement. Also in Deserto rosso (1964), Antonioni explored the malaise of contemporary society, portraying the condition of depression and post-natal alienation of a young mother, dealing with the lack of empathy and understanding of her husband, a rich industrialist.

However, the literary and cinematic panorama thus far described looked to have been totally transformed in the 1970s, when the tendency observed in the previous decade was subjected to a radical inversion. In the hot autumn of Italy, in fact, cinema turned into the privileged means to convey the diffused social discontent, whereas the attention that literature devoted to the themes of industrial work, the factory as a space of political struggle, and the new, alienating, urban life gradually diminished. Terrorism took center stage in literature (Ward 2017), while the struggle of workers and their sufferance seemed by then to be no longer perceived as a topical matter. A notable exception to this trend is Balestrini's Vogliamo tutto (1971), a late example of an industrial novel. The book revolves around the life of a southern worker hired at Fiat Mirafiori in Turin, who moves from passive acceptance of the factory's rules to violent rebellion against the industrial exploitation and the dehumanizing oppression of a capitalist economy. Although the industrial world is no longer the privileged topic of fictional narratives, it features extensively in the Feltrinelli series Franchi Narratori. Published between 1970 and 1983 and edited by Balestrini and Tagliaferri, "la collana dei Franchi Narratori raccoglie quei testi, 'irregolari' rispetto ai parametri sia della letteratura pura sia del semplice documentarismo, in cui si raccontano esperienze direttamente vissute dagli autori stessi, e che rappresentano 'spaccati' di problematiche profondamente vincolate alla realtà storico-sociale della situazione culturale di oggi." Although the series deals mostly with the psychological side of alienation, Di Ciaula's Tuta blu: Ire, ricordi e sogni di un operaio del Sud (1978) returns to the themes of industrial literature. However, the perspective is radically transformed: whereas in the 1960s writers and intellectuals entered the factory and denounced its discontents, it is now the worker himself that offers the first-person autobiographical account of the condition of alienation that he experienced in the "maledetta fabbrica" (Di Ciaula 1978, p. 52). 
In the 1970s it was cinema that continued to look at the condition of alienation and denounced it as the malady of the industrial world. The perspective was transformed, however. While in the years of the boom literature had entered the factory gate, exploring its space as an exotic and estranging dimension, the 1970s witnessed a clear shift in focus. In this decade, what interested film-makers the most was the struggle outside the factory, triggered by unacceptable working conditions, rather than work inside the industry. In other words, whereas in the 1960s literature portrayed the alienated condition of workers and the effects of the spreading "industrial disease" on society, cinema in the 1970s recounted the hot autumn as the workers' fight for liberation from the condition of alienation. The two most paradigmatic examples in this respect-La classe operaia va in paradiso (Petri 1971) and Trevico-Torino - Viaggio nel Fiat-Nam (Scola 1973) - portray the development of class-consciousness in workers, from being functioning tools at the service of the factory to gradually regaining psychological and political agency. Other interesting cases are Mimi metallurgico ferito nell'onore (Wertmüller 1972) and Romanzo popolare (Monicelli 1974). These films are concerned with a different, but equally disruptive, form of alienation: the feeling of estrangement of southern workers in northern cities, and the dramatic effects-as well as violent consequences - of this displacement, affecting private lives and family relationships.

Over the 1970s a novel understanding of alienation-that of low-grade, white-collar workers-started penetrating popular culture. In 1973 the concept album Storia di un impiegato by the Italian songwriter Fabrizio De Andrè was released. The storyline is based on a white-collar worker who, tired of his mind-numbing desk job, decides to join the 1968 protest, becoming a terrorist. Interestingly, the white-collar worker's feeling of alienation and impotence is directly linked to the choice to join the armed struggle, conceived as a way to escape the monotonous and depressing middle-class lifestyle. It is therefore the alienating and frustrating space of the office, with its bureaucratic order, that now turns into a dimension of alienation and, consequently, the cradle of political subversion.

"Middle-class" alienation is also central in Fantozzi, by Luciano Salce. Released in Italian cinemas in 1975, Fantozzi is a very popular cinematic saga (nine sequels in total) whose protagonist, the accountant Ugo Fantozzi, is a tragicomic character overwhelmed by both a harsh exploitation in the workplace and his dysfunctional family at home. Through the bitter-sweet tones of comedy, the Fantozzi series lucidly represents a clear 
shift in the spaces of alienation, from the factory of the boom to the Italian post-miracle corporate-the Megaditta (mega-company) portrayed as a total institution that controls and exploits Fantozzi, in both his professional and private life. As Ancione rightly observes, the alienation of the assembly line and its exhausting pace exceeded the dimension of the factory, now invading the domestic space: to get to work on time, "Fantozzi has organized his early morning actions around Taylor's scientific model: as a series of repetitive actions to be completed in a specific time" (Ancione 2017, par. 6). Popular cinema therefore captured a fundamental turning point in the understanding of alienation: from being represented as an exclusively industrial disease affecting the working class, from the mid1970s it turned into the malady of an oppressed and unhappy middle class.

\subsection{Mental Alienation and the Asylum}

Perhaps in different ways, but certainly with the same impetus, mental alienation was also at the center of debates and struggles during the 1960s and 1970s in Italy. While, on the one hand, Italian psychoanalysis explored this phenomenon, both within and outside the setting, on the other, and most famously, psychiatry was at the forefront of the struggle against alienation, understood in psychological but also, and perhaps especially, in social terms.

The use of the term alienation in reference to mental disorders is rather distant from its use in Marxist terms. It is documented as far back as Roman Hippocratic medicine, with the term alienatio mentis commonly referring to a variety of mental disorders (see Thumiger and Singer 2018). Mental alienation in this light comes to signify one's being other (alius) from oneself; being estranged from oneself. By the early nineteenth century, when psychiatry started to be defined as an independent medical discipline, the term "mental alienation" and its equivalents in the Romance languages (aliénation mentale in French, alienación mental in Spanish, alienazione mentale in Italian, for instance), were ubiquitous in medical treatises. The term was not used consistently by all authors, but the majority employed it as an umbrella notion to refer to all mental disorders, reserving different terms for the actual classification (e.g. in Italy: frenopatia, frenosi, psicosi, pazzia, follia) (see Salomone and Arnone 2009). In French, Spanish, and Portuguese the term came to define the very medical discipline devoted to the study, "treatment," and especially containment of madness, aliénisme/alienismo, and, wherever it was used, it defined the 
physician who worked with mental disorders in the institutional context of the asylum: alienist in English, aliéniste in French, and alienista in Italian.

This term was still commonly used in early 1960s Italy, when two anachronisms dominated mental health care. The first was the law that used to regulate psychiatric "health care" before 1978. Law 36 (Disposizioni sui manicomi e sugli alienati) dated back to 1904, and stated that those affected by "alienazione mentale" should be "custodite e curate nei manicomi" when they are "pericolose a se" o agli altri e riescano di pubblico scandalo" (Art. 1). The second article of the law highlighted that anyone could request someone's admission to the asylum "negli interessi degli infermi e della società," whereas Article 3 stated that discharge could be authorized only by the director of the asylum and the judge. The only additions to the law, which remained in force until as late as 1968, were applied during Fascism, in the infamous 1930 criminal code nicknamed "Codice Rocco." Articles 714 to 717 defined as crimes the following: not admitting an "alienato mentale" to the asylum or a private facility, not reporting the escape of someone interned in an asylum, and, finally, not reporting that someone was suffering from a dangerous mental illness. The respective code of criminal procedures, at Article 604, stated that involuntary hospitalization in an asylum was to be added to a criminal record, sealing an inevitable connection between social dangerousness, mental disorders, and criminality.

The second anachronism was that mainstream psychiatry resolutely rejected all possible alternatives to organicism, including advances in social psychiatry or psychoanalysis. This "narrow, materialistic, and anti-spiritual foundation" (Donnelly 1992, p. 28) is embodied in the official rejection of the term psichiatria, replaced by freniatria, which, according to Livi, cofounder in 1875 of the journal of the Società Italiana di Freniatria, the Rivista Sperimentale di Freniatria, "meglio d'ogni altra include il concetto della sede materiale organica in cui si elaborano" (Livi 1875, p. XXVII). This found a correspondence in the education of specialists as, since the Gentile reform in 1923, psychiatry and neurology were conflated in the same curriculum of "clinica delle malattie nervose e mentali." The exclusiveness of this approach was limited at best, as it had hardly any application to clinical practice. Psychiatric diagnosis by organic means (e.g. through biomarkers) was, and by and large still is, impossible (see Venkatasubramanian and Keshavan 2016), and until the appearance of the first effective antipsychotic drugs (in the mid-1950s), it was commonly accepted that "di terapeutico c'è poco da fare" (Colucci and Di Vittorio 
2001, p. 19) - raising doubts about the actual curability of mental disorders.

With some notable exceptions (such as the introduction of art therapy in the asylums of Imola and Verona, see Babini 2009, p. 163ff), this double anachronism painted the panorama of psychiatry in the 1950s: asylums that were overcrowded (approximately 90,000 beds for 160,000 in need, see Balduzzi and Balduzzi 1981) and understaffed ( 1 psychiatrist per 124 patients on national average, see Realmuto et al. 1962), where people were committed on judicial rather than medical grounds, because of their alleged dangerousness, and in which psychiatrists had virtually no effective tools to treat mental disorders. To all intents and purposes, asylums had become spaces of double alienation: not only were their inmates suffering from mental alienation, they were themselves alienated by, and from, society.

Against this double alienation and double anachronism, a war raged in 1960s and 1970s Italy with the aim of reforming psychiatric health care. The awareness that it was "enorme che un Cittadino, per il fatto di essersi ammalato, venga 'chiuso in un manicomio,' per essere trattato non più come un uomo ma come un alienato, privato di ogni libertà e di particolari diritti" (Trentanove 1966, p. 2) was becoming overwhelming. Winds of change blew in from different directions, "esperienze [...] eterogenee e asincrone, legate dal comune obiettivo del superamento del manicomi" (Babini 2009, p. 242): the inclusion of psychiatry in the university curriculum, independent from neurology (the first chair of psychiatry was Cazzullo in Milan in 1959); the application of rehabilitative aims to psychiatric hospitalization, and thus the education of social workers and teamwork (spearheaded, for instance, by psychiatrists Margherini, Zeloni, and Mori in the San Salvi asylum in Florence, and advertised in their journal Assistenza psichiatrica e vita sociale); experimentation with alternatives to purely biological and institutional psychiatry, such as interpersonal psychiatry, psychotherapies, and psychoanalysis (e.g. Gruppo milanese per lo sviluppo della psicoterapia), phenomenological psychiatry (e.g. Borgna in Novara, Cargnello in Brescia and Callieri in Rome), social psychiatry, and therapeutic community (e.g. Piro in Nocera Superiore); ample projects of reform, including adoption of the French model of "sector psychiatry" (e.g. Perugia, see Foot 2015, ch. 17); and even more limited and localized attempts at humanizing the asylum (e.g. Tobino in Lucca).

The most famous of these reformist psychiatrists, and certainly the most "radical," to borrow Foot's word (Foot 2015, ch. 2), was Franco Basaglia. Much has been written on Basaglia, ${ }^{6}$ and therefore a brief 
summary will suffice. After working in a university clinica di malattie nervose e mentali, Basaglia reached a dead end in his academic career, possibly because of his outspoken sympathies for phenomenological psychiatry within a particular context, namely, Belloni's clinic in Padua, which did not accept deviations from the standard organic approach of Italian freniatria. He was then appointed director of the asylum of Gorizia (1961-1969), Colorno (1970-1971), and finally Trieste (1971-1979). He is best remembered for a law that is erroneously named after him (see e.g. Foot 2015), Law 180 of 1978 (later embedded in Law 883, which regulated the public health care system), de facto abolishing all forms of public residential facility for psychiatric health care (including asylums, mental hospitals, and psychiatric wards in general hospitals) and more closely regulated involuntary hospitalization (under Law 36 involuntary hospitalization could last thirty days, after which it became open ended, while under Law 180 it can last up to seven days and has to be renewed every seven days thereafter).

While he was not the proponent of the reform, in principle the law conflated Basaglia's approach with that of other reformist psychiatrists, and with the urgency of reforming psychiatric health care tout court. From lagging behind all Western countries in terms of psychiatric legislation, Italy suddenly leaped into the lead, spearheading a radical process of deinstitutionalization that remains unrivalled today.

\subsubsection{Philosophical Coordinates: Subjective and Social Alienation}

This process stemmed initially from Basaglia's dissatisfaction with mainstream freniatria. During his years in the university clinic, Belloni famously nicknamed him 'il filosofo' because of his readings: Binswanger, Jaspers, and Minkowski, to name but the best known, were Basaglia's key references. All of them were practicing psychiatrists, but to the organicist eye they were little more than philosophers, since their clinical practice (and nosological work) was not grounded on the assumption that mental disorders have biological roots. Rather, disregarding the possible organic correlations of mental disorders, they focused on the manifestation of the disorder within the actual life that each individual was living; thus, despite their often profound differences, they were all grouped under the umbrella term "phenomenological psychiatrists." At the center of interest for the phenomenological psychiatrist is neither the disorder itself, as a clinical category, nor its possible 
organic aetiology, but the individual who is suffering - this, at least, is one of the most recurrent definitions of phenomenological psychiatry (see, for example, Colucci and Di Vittorio 2001). For Basaglia this was the central feature that such a "philosophical" stance could contribute to psychiatry: it placed the individual suffering subject at the center of its intervention.

Especially after the encounter with the reality of the asylum, however, such an approach proved insufficient to alter the discriminatory, unilateral, and alienating clinical relationship that a heavily institutionalized practice of psychiatry would impose. Between 1961 and 1978, Basaglia's contribution in practical terms was pivotal to the reform: he employed the therapeutic community; abolished physical restraints (e.g. straitjackets) and shock therapies, white coats and patients' uniforms; adopted open ward and open door policies; provided art and theatre therapy; arranged trips and holidays with the patients; coordinated protected communities outside the asylum; and also employed very effective media strategies with the intention of increasing the general population's awareness of mental health issues, especially of the inhuman conditions that patients suffered in asylums (see Pitrelli 2004). As Basaglia declared in his 1964 "manifesto" paper, he was "destroying the asylum," and he was doing it "from the inside," "negating" an institution-to borrow another motto of his, from his other manifesto publication, L'istituzione negata (1968)—while at the same time managing it. These clinical but also social and cultural experiments pioneered the reform of psychiatric health care.

There were, however, at least three rungs in Basaglia's ladder toward the radical de-institutionalization prompted by Law 180, and the jump between them is not insignificant: from applying an alternative psychiatric approach (i.e. phenomenological psychiatry) to reforming everyday lifeunderstood not only in clinical terms-in the mental hospital, and then from internal reform to the destruction of the psychiatric hospital tout court. Although urgent and necessary, alternative clinical approaches and internal reforms were insufficient insofar as they lacked "l'analisi di quanto costituisce e fonda il sociale cui si riferisc[ono]" (Basaglia 1970, p. 598). Internal reforms would just create a "gabbia d'oro" (Basaglia 1964, p. 267), a humanized instrument that society could continue to use to marginalize its deviants. The destruction of the psychiatric hospital was therefore the only "urgently necessary," if not plainly "obvious" (Basaglia 1964 , p. 263), action of radical de-institutionalization. 
From returning the attention to the suffering subject to embedding institutional criticism in psychiatric practice, Basaglia's work in the asylum(s) he directed and his writings effectively bridge the subjective dimension of the suffering individual with the wider sociopolitical context, involving in his analysis a phenomeno-existentialist reading of subjectivity, psychopharmacology, the impact of institutionalization on the inpatients, the clinical but also the sociopolitical role of psychiatrists, and the influence of the capitalist (and bourgeois) system on medicine and psychiatry, among others (see Sforza Tarabochia 2013, p. 187ff). To all intents and purposes, this bridges a phenomeno-existentialist stance with a Marxist one, an operation in which Basaglia was much indebted to the French philosopher Jean-Paul Sartre.

Unfailingly, scholars who write on Basaglia (e.g. Colucci and Di Vittorio 2001 ) note that 1961 was a crucial year in the history of Italian psychiatry. Basaglia took on the role of director in the asylum in Gorizia, while at the same time several works critical of traditional and institutional psychiatry were published: Foucault's (2006) History of Madness, Fanon's (2001) The Wretched of the Earth, and Goffman's Asylums (1961). Another crucial event took place, however. Sartre was invited to a conference at the Istituto Gramsci in Rome. In his paper, Sartre presented the issue of subjectivity in relation to Marxism, and in particular a possible way in which to reconsider subjectivity within Marxist theory. Sartre attempted to account for the individual as the center of experience and as an active, subjective, agent within economics at the same time. He also, and maybe especially, tried to relaunch and innovate Marxism. Phenomenology, existentialism, and Marxism converged into a study of the subject understood as alwaysalready "in situation," a situation that must be analyzed in social, historical, and political terms. While Sartre was not the first to argue for such a convergence (Vietnamese philosopher Tran-Duc-Thao had already established a potential dialogue between phenomenology and Marxism in 1951), his work was certainly the most influential on Basaglia.

Sartre's aim was to debunk Lukcás's Marxism insofar as it creates an “'idealist dialectics,' which in practice ignores the subject" (Sartre 2016, ch. 0 par. 1). In Lukcás's Marxism, Sartre opposed a conception of subjectivity "understood as perpetual projection, and to the extent that it is a mediation it can only be the projection of being within - en deça - onto being beyond" (Sartre 2016, ch. 9 par. 2). According to Jameson (2016, par. 2), Sartre's conference in Rome "betray[s] the continuity between Being and Nothingness and the Critique [of Dialectical Reason]" or, in 
other words, the continuity between a more markedly ontological and existential analysis of subjectivity and a social, political, and historical one. This also bridges an ontological, constitutive understanding of alienation with a Marxist one.

In Being and Nothingness (1953), Sartre affirms that the "very meaning of our free choice is to cause a situation to arise which expresses this choice, a situation the essential characteristic of which is to be alienated; that is, to exist as a form in itself for the Other. We cannot escape this alienation since it would be absurd even to think of existing otherwise than in situation" (Sartre 1978, p. 526). Alienation is thus a constitutive and fundamental part of our subjectivity, consisting of being always-already in situation, objectified by the Other, and objectifying the Other. In the Critique of Dialectical Reason alienation comes to assume a more markedly Marxian connotation. Individuals alienate themselves in the inertia of class practices. In other words, alienation means that free praxis coincides, inertially, with class practice, with the "crystallised practice of previous generations," whereby "individuals find an existence already sketched out for them at birth" (Sartre 2004, p. 232). Alienation "in a Marxist sense, begins with exploitation" (Sartre 2004, p. 227). This notion of alienation, however, does not replace the one Sartre developed in Being and Nothingness. According to Bell, the Critique "offers [...] an important distinction between kinds of alienation: fundamental alienation is distinguished explicitly from 'Marxist' alienation” (Bell 1979, p. 418).

This double acceptation of alienation is evident in Basaglia's work. There are three stages in his conceptualization of alienation. In the first, explicated mostly in "Corpo, sguardo, silenzio" (1965), alienation is regarded as a key part of becoming oneself. In encountering the other, the subject is objectified by his/her gaze. This makes the subject aware of his/ her "facticity," and in turn enables the subject to be the objectifying gaze of the other. When subjects are in a condition of what we could call "reciprocal alienation," a relationship of alterity is established. According to Basaglia, however, mental disorders disrupt this process, effectively "shrinking" to different extents and in different ways the "existential possibilities" of the subject. Regardless of the causes of this shrinking-as a phenomenologist Basaglia is interested in what can be seen in those suffering from a mental disorder, not its roots - the effect is that alterity cannot be established and the patient falls into a state of "alienity." Alienation, if not negotiated and reciprocal and leading to a relationship of alterity, can be pathological (a stance that brings Basaglia remarkably close to a thinker 
who would otherwise be very distant, Lacan-see Sforza Tarabochia 2014). In a second stage, according to Basaglia, institutional psychiatry latches onto this constitutive and potentially pathological alienation of the subject and redoubles it: inpatients are thrown into a state of promiscuity in which they cannot negotiate their alterity. Institutionalization consists of the ill effects of admitting someone who is suffering from a mental disorder in:

Un luogo paradossalmente costruito per il completo annientamento della sua individualità, come luogo della sua totale oggettivazione. Se la malattia mentale è, alla sua stessa origine, perdita dell'individualità, della libertà, nel manicomio il malato non trova altro che il luogo dove sarà definitivamente perduto, reso oggetto dalla malattia e dal ritmo dell'internamento. (Basaglia 1964, p. 262)

This forced alienation, however, is not simply the alienation of the inpatient. Basaglia concludes that alienation in the asylum is a reflection of social alienation, the reflection of a society estranged from itself, unable to harmonize those suffering from mental disorders and capable only of marginalizing them. Institutional psychiatry is therefore regarded as an instrument of social control. This is the third stage of the conceptualization of alienation: psychiatrists, nurses, and the staff themselves are alienated from their purpose of helping those suffering from a mental disorder, and become perpetrators of social control, "funzionari del consenso" (Basaglia 1974, p. 704).

\subsubsection{Mental Alienation Represented}

These considerations were far from being locked behind the walls of asylums, and the issue of psychiatric health care became, as much as the factory, a physical and symbolic battlefield on which social and political struggles were fought. As Pitrelli (2004) has shown, one of the central political strategies in the struggle against institutional psychiatry was a symbolic and metaphoric (ahead of physical) opening of the gates of the asylums. This created a two-way exchange.

On the one hand, slowly, over the course of a decade at least, inpatients were progressively let out of mental hospitals, something that took place also thanks to 1968's Law 431 (remembered as Legge stralcio Mariotti), which canceled the obligation to notify the criminal records office about 
involuntary hospitalization and introduced a voluntary form of hospitalization (Art. 4 left a loophole that allowed existing inpatients to convert their involuntary hospitalization to a voluntary stay). This took various forms, which were at times politicized in connection with the students' movements and social upheavals of the late 1960s, such as protests (e.g. the nurses' demonstration in Parma in the spring of 1968) and occupations (e.g. that of Colorno's asylum in Parma in early 1969). At times these events were independent from political aims, and their purpose was to involve inpatients in initiatives outside the asylum (e.g. the "Festa delle castagne" in Trieste in 1973, or the Alitalia flight with inpatients in 1975) or to make the general public aware of what was happening behind the locked doors of asylums, with large-scale marches and demonstrations (e.g. the Marco Cavallo march in Trieste in 1973).

On the other hand, the gates of the asylums were progressively opened to the general public, fostering a merger between two spaces, the city and the asylum, that had been divided and separated for decades. Initially this opening was not extensive: journalists, photo-reporters, and film directors were invited to bear witness to the abysmal conditions within asylums and/or the reforms that were taking place. The outputs of these invitations were numerous: magazine and newspaper articles (see Furlan 2016); photobooks (e.g. D'Alessandro's Gli esclusi, Cerati and Berengo Gardin's Morive di classe, both in 1969; Butturini's Tu interni, io libero in 1975); and documentaries for the big and the small screen (Napolitano's 1904 n.36, shot in the same asylum as D'Alessandro's Gli esclusi, in 1967; Zavoli's I giardini di Abele (1969), which aired on RAI 1; Agosti, Bellocchio, Petraglia, and Rulli's Matti da slegare (1975); and Dofles, Parascandolo, and Siniscalchi's Dietro l'alibi della follia (1976), shot for RAI 2 Cronache).

In the ten years between Law 431 of 1968 and Law 180 of 1978, the opening of the asylum to the general public became much more extensive, especially in Trieste, which under Basaglia's direction had become a World Health Organization "pilot area" for psychiatric health care in 1973 (see, for example, Foot 2015, ch. 22). Numerous public concerts were organized within the walls of the asylum, including appearances by Gino Paoli, Franco Battiato, and Moni Ovadia. In September 1977 around 4000 people attended the third meeting of the Réseau internazionale di alternativa alla psichiatria, organized within the asylum in Trieste. The third meeting included prominent guests such as Deleuze, Guattari, and Cooper, in addition to artists and musicians, among them Dario Fo. 
Perhaps surprisingly, despite the involvement of journalists, photographers, cinematographers, musicians, and actors, the struggle against alienation in the asylum is much less represented than it was in the factory. While indeed a wealth of non-fiction was produced (e.g. articles, photobooks, documentaries), literature and cinema featured more limited output.

The first literary voice from within the asylum emerged early, in 1953, and remained the only one for a long time, at least twenty years. Mario Tobino, writer and psychiatrist, director of the asylum in Maggiano, published in 1953 Le libere donne di Magliano, a distinctly autobiographical novel set in a fictional asylum (in Magliano-just one consonant away from his real asylum in Maggiano). He continued the story of Magliano (and his autobiographical narration) in 1972 with Per le antiche scale and, finally, in 1982 through Gli ultimi giorni di Magliano. Per le antiche scale was also adapted for the big screen by Bolognini in 1975 .

Mental disorder is at the center of the 1964 novel Il male oscuro, by Berto, in which the author narrates his life and mental disorder (depression and hypochondria) through a stream of consciousness. The protagonist (and author's alter ego) undergoes psychoanalysis, which partially solves his problems. Whereas Berto's novel revolves around neurosis, Ottieri's L'irrealtà quotidiana, published in 1966, is the book through which a psychological account of alienation became a literary topic in its own right. This text, combining a novelistic approach with the scientific nature of an essay, can be read as a transition from Ottieri's earlier literature of the factory-in which alienation is explored as a social phenomenon-and his later work, in which the alienated mental state takes the shape of a purely clinical matter examined through the lenses of psychoanalysis and psychiatry. This clear shift is highlighted at a lexical level. The replacement of the ideologically connoted term alienation with the word irrealtà (meaning a feeling of detachment from reality and a sense of depersonalization) signals Ottieri's will to break with an exclusively political take on the matter, as well as the author's challenge to the view of alienation as an industrial disease only. The set of texts witnessing this change of perspective-Campo di concentrazione (1972), Contessa (1976), and the collection of poems La corda corta (1978) - all explore the psychological feeling of alienation by recording the suffering of subjects confined within the space of the clinics. However, in these works Ottieri demonstrates that he is one of the most anti-Basaglian writers in Italian literature. Besides never mentioning the fight against asylums as Italian institutions, Ottieri praises a pharmaceu- 
tical and organic-based psychiatry, the only approach that, for him, can liberate the subject from mental disorders, which he explicitly compares to the prisoners' condition of physical confinement (Ottieri 1972, pp. 14 and 102). As a result, for Ottieri, it is the pathological condition-and not the loss of freedom experienced within the clinical space-that should be perceived as a metaphorical place of confinement. It is therefore not the mental health institution that should be compared to a prison but, rather, the lack of freedom and the loss of political agency that alienated states induce. According to the author, curing psychological disorders does not coincide with forcing subjects to accept social structures, suppressing their deviant-and therefore revolutionary-behavior. On the contrary, it is the medical approach-even if imposed upon the suffering subject-that restores the possibility for the patient to enjoy a public and social existence once more.

In 1968, Italian film director Nelo Risi brought to the big screen the book Journal d'une schizophrène, written by a French psychoanalyst, Sechehaye (1968), who pioneered the psychoanalytic treatment of schizophrenia and influenced anti-psychiatrist Laing. Risi's film, Diario di una schizofrenica, follows Anna's story from her commitment to a private psychiatric clinic to her therapeutic relationship with Bianca, a logopaedist. Interestingly, Sechehaye's book is also mentioned in Giuliani's preface to the anthology I Novissimi. The subversion of language that the new avantgarde movement performed seemed to reproduce the distortion of language provoked by schizophrenia. The challenge to a fixed understanding of reality that these poets perform is defined as a "visione schizomorfa" of reality (Giuliani 1965, p. 19), an idea that establishes a clear link between the revolutionary subject and the psychiatric patient.

A short, first-hand, literary account of life in an asylum came in 1970 with writer and painter Vigevani's short story "Diario da un manicomio," included in his debut collection Dalla pancia di un orso bianco. This story is based on Vigevani's work as a volunteer in the San Salvi asylum in Florence. The protagonist, an unnamed long-term inpatient in an unnamed asylum, witnesses through a stream of consciousness the years of "dis-alienation:" the first meetings with members of staff (therapeutic community), lectures on the "total institution," trips outside the asylum, "sociotherapy," and so on.

Gianni Celati's debut novel, Comiche (1971), is instead a second-hand narration, as it is based on the unpublished diaries of an inmate of the Pesaro mental asylum, written in the late nineteenth century. Celati, who 
was a good friend of Basaglia, used his comedic language to undermine institutional psychiatry.

In 1973, Feltrinelli published in its aforementioned series Franchi Narratori (which started in 1970 with the translation of Loyd and Williamson's Born to Trouble: Portrait of a Psychopath) Maria Luisa Marsigli's autobiographical account of her incarceration in a criminal mental asylum, entitled La marchesa e $i$ demoni. Her first-hand account, a unique text in the Italian literary panorama of the 1960s-1970s, was prefaced by Basaglia, according to whom "mette a nudo i meccanismi [...] e le contraddizioni dell'istituzione," showing how the aim of the asylum is the "totale annientamento dell'internato e la sua identificazione con l'immagine di se' che l'istituzione gli offre: quella del sotto-uomo" (Basaglia 1973, p. 690).

Berto returned to mental disorders in 1974 with Oh Serafina!, tellingly subtitled Fiaba di ecologia, di manicomio e d'amore. Augusto, the protagonist, is unable to manage the factory his dead father left him, because of his lack of managerial skills and his love of nature. His greedy wife has him committed to the asylum, where he meets Serafina, a "hippy," with whom he can develop a love story unbound by financial interests. Lattuada adapted Berto's novel to the big screen in 1976 as a comedy with the same title, featuring Renato Pozzetto.

One of the most famous Italian literary voices of life in the asylum, quite tellingly, did not emerge from within the asylum. Between 1962 and 1979, during her numerous hospitalizations for bipolar disorder in the Paolo Pini asylum in Milan, Alda Merini did not write. Her work saw the light of day only after 1979. L'altra verità: Diario di una diversa, her diary (and first work in prose) of the time she spent in the Paolo Pini, was published only in 1986.

Apart from the abovementioned documentaries and adaptations, cinema equally features a relative paucity of representations of alienation and asylums. Giannetti's debut film Giorno per giorno, disperatamente, released in 1961, tells the story of a man, Dario Dominici, from the Roman outskirts, who falls ill with a mental disorder. The life of the family is thrown into turmoil and Dario is committed to an asylum. His mother spends all their money trying to bribe the nurses to treat him well and then has him discharged to take him to Vienna for a 'miraculous cure' (could this be an allusion to psychoanalysis?). Dario has a final crisis, threatens his mother to death, and is interned in the asylum, this time for life. Giannetti's film is an exception in the Italian panorama, as most of the films featuring mental 
alienation or the asylum are centered around women suffering from mental disorders, including the abovementioned Deserto rosso, in which the protagonist, Giuliana, is tormented by a depression seemingly caused by the meaninglessness and emptiness of post-industrial modernity.

In 1971, Tosini directed La casa delle mele mature, a drama in which the two female protagonists, committed to an asylum, live the full extent of the "manicomio-lager" simile, with electroshock used as punishment, straitjackets, and the exposure and exploitation of female bodies, among other things.

The representation of mental alienation on the big screen, however, mostly consists of misrepresentation or outright exploitation of the theme of madness. A number of comedies revolve around women with mental disorders; for instance, 1954 Cose da pazzi by Pabst, which features a sane woman interned in an institution run by an insane psychiatrist, or 1964 episodic film Queste pazze pazze donne, by Girolami, in which a psychiatrist tells four stories of female madness with comic overtones. Finally, there are numerous horror films, B-movies, and exploitation films that, perhaps unsurprisingly, revolve around madness or are set in asylums, examples of the former being La lama nel corpo (De Felice 1966), La bestia uccide a sangue freddo (Di Leo 1971), and Il diavolo nel cervello (Sollima 1972); and of the latter Rivelazioni di uno psichiatra sul mondo perverso del sesso (Polselli 1973) and Emanuelle Nera 2 (Albertini 1976).

Popular culture also exploited the theme of mental alienation at a more innocent level: in 1964 Romano Scarpa, the Italian Disney illustrator, invented the character Sgrizzo Papero (translated into English as Kildare Koot, who appeared only twice: in 1964 in Topolino 465 and in the 1988 Paperolimpiadi saga, in Topolino 1705 to 1712). Sgrizzo Papero was replaced by Fethry Duck (in Italian Paperoga), designed in the USA by Hubbard and Kinney in the same year (1963). Unlike Fethry Duck, Sgrizzo Papero was declared insane (Scarpa himself describes him physiognomically in the first vignette of the 1964 comic: "Vedete? Ha la tipica espressione del matto!") and even spent time in some sort of clinical facility.

A diametrically opposed representation of mental disorders, and perhaps the most "Basaglian" depiction of mental and social alienation in popular culture, is found in music. In the 1971 song "Un matto (Dietro a ogni scemo c'è un villaggio)," Fabrizio De André plays on the expression "scemo del villaggio" (village idiot): behind every idiot there is a village, a community that rejected him. The protagonist of the song, un matto, hav- 
ing trouble expressing in words his "mondo nel cuore," tries to learn the encyclopedia by heart. ${ }^{7} \mathrm{He}$ is committed to the asylum upon getting to the letter M (Matto) and dies there, inventing words. However, De André seems to say that the joke is on the "village," which has to confront the emptiness left by madness, now safely locked away in the asylum: "la vita è rimasta nelle voci in sordina di chi ha perso lo scemo e lo piange in collina." In 1973, with the song "Dall'altra parte del cancello" from the album tellingly entitled Far finta di essere sani (pretending to be sane), Giorgio Gaber blurs the distinction between mental alienation and "normality." Behind the "sbarre sempre chiuse di un cancello" there is "un uomo matto," who is, in fact, just an abandoned, forsaken, and lonely man. On the other side of the gate there is "us:" "noi che siamo normali." Since we can "contare sul cervello," we express our "sentimenti così normali" with "gesti equilibrati" that "non danneggiano nessuno." We are thus free, have access to education, to a "buon lavoro," and an "esistenza piena di rapporti umani." Yet what distinguishes "us" from "them," and makes our fates so different, Gaber suggests, is entirely arbitrary: "noi fuori dal cancello $[\ldots]$ abbiamo la fortuna di esser sani," and nothing more.

\subsection{Summary OF Chapters}

Italian cultural production between the economic miracle and the years of lead is characterized, as we have seen, by an interest, at different levels and to different extents, in the notion of alienation. Whether it is understood in social terms, interpreted through a Marxist perspective, or in psychological terms, as mental alienation, the notion emerges at the level of representation in literature, cinema, photography, and the arts, including expressions of popular culture. At the same time, the sociopolitical sphere is moved by tendencies toward what we could call "dis-alienation." While alienation is recognized, attempts are made to reduce it; for instance, reforming the statute of workers and psychiatric health care, to name but the most prominent examples cited above.

The following chapters explore individual aspects of alienation or disalienation as they emerge in the different fields outlined in this introduction. The chapters are organized into four parts: "Spaces of Alienation," "Workers at Olivetti," "Psychoanalysis and Alienation," and, finally, "The Asylum."

In the first part, Emanuela Sorbo explores the deconstruction of the psychiatric space as a space of alienation by deploying Tafuri's Marxist and Foucauldian criticism of architecture. According to Sorbo, Italian 
psychiatric hospitals, built in the late nineteenth and early twentieth centuries with functional ideals in mind, conform to, and reiterate, institutional power. As they were abandoned, thanks to Law 180, they became paradoxical spaces of both forgetting and memory. Fabio Camilletti develops a metaphorical conception of the space of alienation by analyzing Emilio De Rossignoli's 1977 dystopian novel Lager dolce lager. Camilletti aims to reinstate De Rossignoli's work, which has so far received little scholarly attention, in the Italian literary canon of the 1970s. In Lager dolce lager Camilletti recognizes a trend, shared with Cavani's Il portieve di notte or Pasolini's Salo, for instance, according to which the camp, understood in broad terms, is presented as a space of alienation that enables the author to reflect on issues of social control, biopolitics, and deviance in other "total institutions," such as prisons, asylums, or even schools.

The second part is dedicated to social alienation, particularly as experienced and analyzed by worker-writers at Olivetti. David Albert Best analyzes works by Volponi and Ottieri, both workers at Olivetti, through Olivetti's own writings on the industrial "Copernican revolution" that he was implementing in his factory. Best identifies in all three authors an ambiguous relationship with the rural dimension, which is evoked as a "cure" for the ills of industrialization, but also as the "dark ages" of Italy. In doing so, Best addresses Italy's traumatic turn toward an alienating modernity and the loss of a relationship with nature. In the following chapter, Fabrizio Di Maio narrows the focus on Ottieri's oeuvre, examining how the notion of alienation is at the root of his poetics. While Best focuses specifically on Ottieri's production of letteratura di fabbrica, Di Maio analyzes the psychological implications of the notion of alienation, discussing Ottieri's description of clinical forms of alienation and their possible treatments through psychoanalysis and self-analysis. According to Di Maio, Ottieri's reading of alienation denounces the subjective and collective ill effects of the onset of consumerism in Italian society. Finally, Tiziano Toracca analyzes Memoriale, arguably one of the best-known works by another worker at Olivetti, Volponi. While Volponi experienced Olivetti's utopian approach to the factory, in his novel he seems to depict it as a "factory of pain." Toracca explains this apparent contradiction by challenging the view that the novel should be regarded as a text that reveals the evil dimension of factory work. According to Toracca, Memoriale instead shows that the pains of the protagonist are intrinsic to the human condition and, if anything, they provoke an existential crisis that can find help inside the factory. 
The third part of the book focuses on psychoanalysis in Italy and psychoanalytical readings of Italian works on alienation. Alessandra Diazzi opens the part by discussing, from a psychoanalytic perspective, the collective sentiment of alienation affecting Italians in the years of the economic miracle. By doing so, Diazzi discusses how Italian psychoanalysis dealt with the notion of alienation, explaining at the same time why the attention devoted to the theme reveals a peculiar "Italian way" of psychoanalysis, looking more at the social side of mental disorders than their psychological genesis. Pietro Barbetta turns his attention to the city of Milan, in particular to the psychoanalyst Fachinelli and his interpretation of Ferenczi's notion of "reciprocity." Barbetta claims that, thanks to Fachinelli and a number of his colleagues, in the 1970s Milan witnessed a radical reform of psychoanalysis, which brought it up to speed with the profound social changes that followed the upheavals of 1968. Luca Di Gregorio concludes the part by deploying a Lacanian psychoanalytic theoretical framework to advance a new reading of Petri's film La classe operaia va in paradiso. According to Di Gregorio, Lacanian theory, better than Freudianism or Marxism, allows a dual notion of alienation to emerge in the film: on the one hand, a sociohistorical manifestation of capitalism; and, on the other, a fundamental condition of human subjectivity.

The fourth and final part brings the reader into the asylum as a space of alienation. The part is opened by Michele Ronchi Stefanati, who analyzes Celati's debut novel Comiche through Basaglia's (a good friend of Celati's) work of reform in psychiatry. According to Ronchi Stefanati, by means of slapstick comedy and bagarre, Celati strongly criticizes the marginalization and institutionalization of irrationality, questioning at the same time the very possibility of representing madness in literature and the arts. Alvise Sforza Tarabochia focuses on the first of several photobooks that accompanied the work of reform of psychiatric health care in Italy, D'Alessandro's Gli esclusi. Sforza Tarabochia claims that the very conditions of readability of D'Alessandro's photographic work are defined by Basaglia's take on alienation, which he shared with the numerous "radical" psychiatrists who contributed to the reform, including Piro, who commissioned Gli esclusi while he was director of the Nocera Superiore asylum. In the last chapter of the book, Wissia Fiorucci analyzes Tobino's fictional works, set in an asylum and based on his experience as director of the asylum of Maggiano, Lucca. Contrary to what has been said so far by the majority of scholars, Fiorucci endorses Andreoli's (2008) claim that Tobino should be held responsible for the unprofessional and uncritical 
representation of institutional psychiatry, which, Fiorucci claims, is derived from his lack of institutional analysis and a romanticized and unscientific view of mental disorders.

\section{Notes}

1. For data on Italy's role in the European market see Ginsborg's chapter 'The Economic Miracle' (Ginsborg 1990, pp. 212-216).

2. For a complete overview of the relationship between Adriano Olivetti and Italian writers see La letteratura al tempo di Adriano Olivetti (Lupo 2016).

3. The debate included, among the others: Vittorini (1961), Scalia (1961), Eco (1962), Moravia (1962). Responses by Pier Paolo Pasolini and Enzo Siciliano followed on L'Espresso, June 3 1962. In this context, we will only focus on the articles that specifically discussed the issue of alienation and its literary representation.

4. The first ten short stories now collected in Marcovaldo were published on L'Unità between 1952 and 1956.

5. For an overview of Italy's letteratura industriale and its major exponents see Bigatti and Lupo (2013).

6. For instance: Foot (2015) develops a comprehensive historical study of Basaglia's work in Gorizia and other, contemporary "radical" experiences in psychiatry. Pivetta (2014) wrote Basaglia's biography. See Colucci and Di Vittorio (2001) and Sforza Tarabochia (2013) for studies on Basaglia's philosophy. See Donnelly (1992) and Babini (2009) for wide-ranging studies on the Italian reform in the context of the history of Italian psychiatry, and, finally, Crossley (2006) for a study of Basaglia's work in an international context.

7. Much like Frank Drummer from Masters's Spoon River Anthology, on which De Andrè based the entire album, and similarly to Sartre's Ogier P., the selftaught man of The Nausea.

\section{REFERENCES}

Ancione, Michele. 2017. The Best Intro I Ever Received on Class Struggle: Il primo tragico Fantozzi. https://www.michelelancione.eu/blog/2017/07/03/thebest-intro-i-ever-received-on-class-struggle-il-primo-tragico-fantozzi/. Accessed 28 Aug 2018.

Andreoli, Vittorino. 2008. Il matto di carta: La follia nella letteratura. Milan: Biblioteca Universale Rizzoli.

Antonello, Pierpaolo. 2012. Dimenticare Pasolini: Intellettuali e impegno nell'Italia contemporanea. Milan: Mimesis. 
Asor Rosa, Alberto. 1982. Lo stato democratico e i partiti politici. In Asor Rosa, Alberto. Letteratura italiana: Il letterato e le istituzioni, 549-543. Turin: Einaudi.

Babini, Valeria. 2009. Liberi tutti: Manicomi e psichiatri in Italia. Una storia del novecento. Bologna: Il Mulino.

Balduzzi, Edoardo, and Cesare Balduzzi. 1981. La loi psychiatrique du 13 mai 1978. Information Psychiatrique 57 (5): 643-646.

Balestrini, Nanni. 1971. Vogliamo tutto. Milan: Feltrinelli.

Balestrini, Nanni, et al. 2013. Gruppo 63: L'antologia, critica e teoria. Milan: Bompiani.

Basaglia, Franco. (1964) 2017. La distruzione dell'ospedale psichiatrico come luogo di istituzionalizzazione. In Basaglia, Franco. Scritti 1953-1980, 261-270. Milan: ilSaggiatore.

—. (1965) 2017. Corpo, sguardo e silenzio: L'enigma della soggettività in psichiatria. In Basaglia, Franco. Scritti 1953-1980, 301-314. Milan: ilSaggiatore.

-. (1970) 2017. Prefazione a Ideologia e pratica della psichiatria sociale. In Basaglia, Franco. Scritti 1953-1980, 595-612. Milan: ilSaggiatore.

-. (1973) 2017. Prefazione a La marchesa $e$ i demoni. In Basaglia, Franco. Scritti 1953-1980, 683-692. Milan: ilSaggiatore.

—. (1974) 2017. Psichiatria e giustizia: Appunti su psichiatria e criminalizzazione del bisogno. In Basaglia, Franco. Scritti 1953-1980, 693-706. Milan: ilSaggiatore.

Bell, Linda. 1979. Sartre: Alienation and Society. Philosophy and Social Criticism 6 (4): 408-422.

Berto, Giuseppe. (1964) 2016. Il male oscuro. Vicenza: Neri Pozza.

- 1974. Oh, Serafina! Fiaba di ecologia, di manicomio e d'amore. Milan: Rusconi.

Bianciardi, Luciano. 1962. La vita agra. Milan: Rizzoli.

Bigatti, Giorgio, and Giuseppe Lupo, eds. 2013. Fabbrica di carta: I libri che raccontano l'Italia industriale. Bari/Rome: Laterza.

Bolongaro, Eugenio. 2003. Italo Calvino and the Compass of Literature. Toronto: University of Toronto Press.

Butturini, Gian. 1975. Tu interni ... io libero: Dibattito fotografico assieme a Franco Basaglia e la sua équipe attraverso la distruzione dell'Ospedale Psichiatrico. Verona: Bellomi.

Caesar, Michael. 1996. The Late 1950s and the 1960s. In The Cambridge History of Italian Literature, ed. Peter Brand and Lino Pertile, 561-580. Cambridge: Cambridge University Press.

Calvino, Italo. 1966. Marcovaldo ovvero le stagioni in città. Turin: Einaudi.

Cerati, Carla, and Gianni Berengo Gardin. 1969. Morive di classe: La condizione manicomiale fotografata. Turin: Einaudi. 
Celati, Gianni. (1971) 2012. Comiche. Macerata: Quodlibet.

Cento Bull, Anna. 2007. Italian Neofascism, the Strategy of Tension and the Politics of Nonreconciliation. New York/Oxford: Berghahn Books.

Chirumbolo, Paolo, and Mario Moroni, eds. 2010. Neoavanguardia: Italian Experimental Literature and Arts in the 1960s. Toronto/Buffalo/London: University of Toronto Press Incorporated.

Colucci, Mario, and Pierangelo Di Vittorio. 2001. Franco Basaglia. Milan: Bruno Mondadori.

Crossley, Nick. 2006. Contesting Psychiatry: Social Movements in Mental Health. London/New York: Routledge.

D’Alessandro, Luciano. 1969. Gli esclusi: Fotoreportage da un'istituzione totale. Milan: Il Diaframma.

Di Ciaula, Tommaso. 1978. Tuta blu: Ire, ricordi e sogni di un operaio del sud. Milan: Feltrinelli.

Donnelly, Michael. 1992. The Politics of Mental Health in Italy. London/New York: Routledge.

Eco, Umberto. (1962) 1997. Del modo di formare come impegno sulla realtà. In Eco, Umberto. Opera aperta, 235-290. Milan: Bompiani.

Eugeni, Ruggero. 2002. La relazione d'incanto. Milan: Vita e Pensiero.

Fanon, Frantz. 2001. The Wretched of the Earth. Trans. Constance Farrington. London: Penguin.

Ferretti, Giancarlo. 1972. Paolo Volponi. Florence: La Nuova Italia.

Foot, John. 2015. The Man Who Closed the Asylums: Franco Basaglia and the Revolution in Mental Health Care. New York/London: Verso. Kindle.

Foucault, Michael. 2006. History of Madness. Trans. Jonathan Murphy and Jean Khalfa. London/New York: Routledge.

Furlan, Pier Maria. 2016. Sbatti il matto in prima pagina: I giornali italiani e la questione psichiatrica prima della legge Basaglia. Rome: Donzelli Editore.

Ginsborg, Paul. 1990. A History of Contemporary Italy: Society and Politics, 1943-1988. London: Penguin Books.

Giuliani, Alfredo, ed. (1961) 2003. I Novissimi: Poesie per agli anni Sessanta. Turin: Einaudi.

-. 1965. Introduzione. In Giuliani, Alfredo. I Novissimi, 15-32. Turin: Einaudi.

Goffman, Erving. 1961. Asylums: Essays on the Social Situation of Mental Patients and Other Inmates. New York: Anchor Books.

Gundle, Stephen. 2000. Between Hollywood and Moscow: The Italian Communists and the Challenge of Mass Culture, 1943-1991. Durham/London: Duke University Press.

Hardin, Garret. 1956. Meaninglessness of the Word Protoplasm. Scientific Monthly $82(3): 112-120$.

Jameson, Fredric. 2016. Afterword: Sartre's Actuality. In What Is Subjectivity? ed. Jean-Paul Sartre. New York/London: Verso. Kindle. 
Johnson, Frank. 1973. Alienation: Overview and Introduction. In Alienation: Concept, Term, and Meanings, Frank Johnson, 3-25. New York: Seminar Press. Lacan, Jacques. 1998. The Seminar of Jacques Lacan. Book XI: The Four Fundamental Concepts of Psychoanalysis. Trans. Alan Sheridan. New York/ London: W. W. Norton \& Co.

Livi, Carlo. 1875. Editoriale: Del metodo sperimentale in Freniatria e medicina legale. Rivista sperimentale di freniatria 1. http://www.rivistafreniatria.it/ VediMacro.phtml!IDMacro=1102\&sLang=IT. Accessed 9 Aug 2018.

Lupo, Giuseppe. 2016. La letteratura al tempo di Adriano Olivetti. Milan: Edizioni di Comunità.

Marsigli, Maria Luisa. 1973. La marchesa e $i$ demoni. Milan: Feltrinelli.

Merini, Alda. (1986) 2013. L'altra verità diario di una diversa. Milan: Rizzoli.

Moravia, Alberto. (1962) 1964. I miei problemi. In L'uomo come fine e altri saggi, ed. Alberto Moravia, 377-379. Milan: Bompiani.

Moroni, Mario, Luca Somigli, and Paolo Chirumbolo, eds. 2010. Neoavanguardia. Toronto: University of Toronto Press.

Murchland, Bernard. 1971. The Age of Alienation. New York: Random House.

Olivetti, Adriano. 1960. Città dell'uomo. Milan: Edizioni di Comunità.

Ottieri, Ottiero. 1957. Tempi stretti. Turin: Einaudi.

—. 1959. Donnarumma all'assalto. Milan: Bompiani.

- 1966. L'irrealtà quotidiana. Milan: Bompiani.

—. 1972. Campo di concentrazione. Milan: Bompiani.

-1976. Contessa. Milan: Bompiani.

. 1978. La corda corta. Milan: Bompiani.

Pasolini, Pier Paolo. (1975) 2013. L'articolo delle lucciole. In Scritti corsari, ed. Pier Paolo Pasolini, 2013. Milan: Garzanti.

-1999. Saggi sulla politica e sulla società. Milan: Arnoldo Mondadori Editore.

Pedullà, Walter, ed. 1968. La letteratura del benessere. Naples: Libreria Scientifica Editrice.

Peterson, Thomas. 2010. The Revolt of the Scribe in Modern Italian Literature. Toronto: University of Toronto Press.

Piccone, Paul. 1983. Italian Marxism. Berkeley: University of California Press.

Pitrelli, Nico. 2004. L'uomo che restitui la parola ai matti: Franco Basaglia, la comunicazione e la fine dei manicomi. Naples: Editori Riuniti.

Pivetta, Oreste. 2014. Franco Basaglia, il dottore dei matti: La biografia. Milan: Baldini e Castoldi.

Realmuto, E., M. Marletta, and M. Leoni. 1962. L'attuale situazione ospedaliera psichiatrica nel nostro paese. (Risultati di una rilevazione a carattere nazionale. Aspetti igienico-sanitari e psico-medico-sociali). Annali della Sanità Pubblica XXIII (6 suppl).

Salomone, Giuseppina, and Raffaele Arnone. 2009. La nosografia psichiatrica italiana prima di Kraepelin. Giornale italiano di psicopatologia 15: 75-88. 
Sanguineti, Edoardo. 1956. Laborintus: Laszo Verga, 27 poesie. Varese: Magenta. Sartre, Jean-Paul. 1978. Being and Nothingness. Trans. Hazel E. Barnes. New York: Pocket Books.

- 2004. Critique of Dialectical Reason. Volume 1. Trans. Alan SheridanSmith. New York/London: Verso.

- 2016. Marxism and Subjectivity. In What Is Subjectivity?, ed. Jean-Paul Sartre. Trans. David Broder and Trista Selous. New York/London: Verso. Kindle.

Scalia, Gianni. 1961. Dalla natura all'industria. Il Menabò 4: 95-114.

Sechehaye, Marguerite. (1968) 2003. Journal d'une schizophrène. Paris: Presses Universitaires de France.

Sforza Tarabochia, Alvise. 2013. Psychiatry, Subjectivity, Community: Franco Basaglia and Biopolitics. Bern/Oxford: Peter Lang.

- 2014. Lacking Subjects and the Subject of Lack: Basaglia and Lacan. In Lacan and Philosophy: The New Generation, ed. Lorenzo Chiesa, 221-238. Melbourne: Re.Press.

Thao, Trân Duc. 1951. Phenomenology and Dialectical Marxism. Trans. Daniel Herman and Donald Morano. Boston/Lancaster: D. Reidel Publishing.

Thumiger, Chiara, and Peter Singer. 2018. Introduction. Disease Classification and Mental Illness: Ancient and Modern Perspectives. In Mental Illness in Ancient Medicine: From Celsus to Paul of Aegina, ed. Chiara Thumiger and Peter Singer, 1-32. Boston/Leiden: Brill.

Tobino, Mario. (1953) 2016. Le libere donne di Magliano. Milan: Mondadori.

- 1972. Per le antiche scale. Milan: Mondadori.

- 1982. Gli ultimi giorni di Magliano, 2009. Milan: Mondadori.

Trentanove, Marcello. 1966. Editoriale. Assistenza psichiatrica e vita sociale 2: 4.

Venkatasubramanian, Ganesan, and Matcheri Keshavan. 2016. Bio markers in

Psychiatry-A Critique. Annals of Neurosciences 23 (1): 3-5.

Vigevani, Roberto. 1970. Dalla pancia di un orso bianco. Milan: Adelphi.

Vittorini, Elio. 1961. Industria e letteratura. Il Menabò 4: 13-20.

Volponi, Paolo. 1962. Memoriale. Milan: Garzanti.

Ward, David. 2017. Contemporary Italian Narrative and 1970s Terrorism: Stranger Than Fact. London/New York: Palgrave Macmillan.

\section{FilMOgRAPHY}

Albertini, Bitto, dir. 1976. Emanuelle nera 2. Rome: San Nicola Produzione Cinematografica.

Antonioni, Michelangelo, dir. 1960. L'avventura. Rome: Cino Del Duca Film.

_

— dir. 1962. L'eclisse. Rome: Cineriz.

— dir. 1964. Deserto rosso. Rome: Cineriz. 
Bellocchio, Marco et al., dir. 1975. Matti da slegare. Parma: 11 Marzo Cinematografica per l'Assessorato Provinciale Sanità di Parma e Regione Emilia-Romagna.

De Felice, Lionello, dir. 1966. La lama nel corpo. Rome/Paris: Ci.Ti. Cinematografica, Leone Film, Orphée production.

Di Leo, Fernando, dir. 1971. La bestia uccide a sangue freddo. Rome: Cineproduzioni Daunia 70.

Dorfles, Pietro, Renato Parascandolo, and Raffaele Siniscalchi, dir. (1976) 2007. Dietro l'alibi della follia. Rome: RAI Trade [DVD].

Giannetti, Alfredo, dir. (1961) 2017. Giorno per giorno disperatamente. Rome: RAI Cinema [DVD].

Girolami, Marino, dir. (1964) 2011. Queste pazze pazze donne. Rome: Medusa [DVD].

Lattuada, Alberto, dir. (1976) 2013. Oh Serafina! Florence: Cecchi Gori Home Video [DVD].

Monicelli, Mario, dir. 1974. Romanzo popolare. Rome: Capitolina Produzioni.

Napolitano, Riccardo, dir. 1967. 1904 n. 36. http://patrimonio.aamod.it/aamodweb/film/detail/IL8600001165/22/1904-n-36.html?startPage=0\&idFond $\mathrm{O}=$ \&multiSearch=true. Accessed 10 Aug 2018.

Pabst, George Wilhelm, dir. 1954. Cose da pazzi. Rome: Kronos.

Petri, Elio, dir. 1971. La classe operaia va in paradiso. Rome: Euro International Film.

Polselli, Renato, dir. 1973. Rivelazioni di uno psichiatra sul mondo perverso del sesso. Rome: G.R.P. Cinematografica.

Risi, Dino, dir. 1962. Il sorpasso. Rome: INCEI Film.

Risi, Nelo, dir. 1968. Diario di una schizofrenica. Rome: IDI Cinematografica.

Rossellini, Roberto et al., dir. 1962. Ro.Go.Pa.G. Rome/Paris: Arco Film, Cineriz, Lyre Film.

Salce, Luciano, dir. 1975. Fantozzi. Rome: Cineriz.

Scola, Ettore, dir. 1973. Trevico-Torino-Viaggio nel Fiat-Nam. Rome: Unitelefilm.

Sollima, Sergio, dir. 1972. Il diavolo nel cervello. Paris/Verona: Marianne Production, Universal Production and Verona Produzione.

Tosini, Pino, dir. 1971. La casa delle mele mature. Rome: Universalia Vision MPI.

Wertmüller, Lina, dir. 1972. Mimi metallurgico ferito nell'onore. Rome: Euro International Film.

Zavoli, Sergio, dir. 1969. Igiardini di Abele. Aired 3 January 1969, on RAI 1. 
Spaces of Alienation 


\title{
Into the De/Construction of the Psychiatric Space
}

\author{
Emanuela Sorbo
}

The notion of alienation as it is explored and unraveled in the Italian cultural context relates first and foremost to the role of the individual within the social system. In line with Foucault's (2006) study of the genesis of "madness" and its relation to marginalization (being outside society), in the 1960s and 1970s the space of alienation was interpreted as the architectural symptom of the State's inability, in terms of local policies, to manage social distress in ways that did not result in the forceful marginalization of the insane. This political answer engendered a debate on the architectural spaces that were planned and conceived as, simultaneously, therapeutic machines and spaces of isolation. The 1970s, then, witnessed the deconstruction of the psychiatric space, as a stepping stone towards the shattering of all institutional spaces that incarnate the thin line between social inclusion and exclusion.

According to Foucault, after the Middle Ages the insane could be regarded as those who prophetically described the world, in their being out of this world but also in it, as buffoons, bearers of truth through laughter. Madness almost reached the religious sphere, as the insane could

E. Sorbo $(\bowtie)$

IUAV University of Venice, Venice, Italy

e-mail: esorbo@iuav.it

(C) The Author(s) 2019

A. Diazzi, A. S. Tarabochia (eds.), The Years of Alienation in Italy, https://doi.org/10.1007/978-3-030-15150-8_2 
be regarded as unofficial prophets. Madness, in its exceptionality, was part of the world (see Foucault 2006).

During the seventeenth century, the codification of behaviors and the construction of a discourse on "society" defined (by subtraction) that which is other to society and rationality. What we could call the construction of a discourse on madness marks the beginning of imprisonment as expulsion from the social sphere.

Along with the Enlightenment and the birth of the "clinic" (Foucault 2003, first English edition 1965), in the eighteenth century the architecture for the insane tended to mimic psychiatric nosology, the classification of mental illnesses and disorders (see Scotti 1984). This culminated, in 1865 (four years after the unification of Italy), in a law that was passed to entrust provinces with the maintenance of the "mentecatti poveri."1

The positivist climate linked medical specialisms with dedicated hospitals and/or wards. The required hygienic rigor prompted the construction of spaces of isolation for mental disorders within the urban context, creating small parallel cities for the treatment of inpatients. As architecture gave visible structure to the ongoing social changes, in the "Novella Italia" the "asili per i maniaci poveri" became the expression of a new unified and social State (see Babini 2011; Crippa 2014; Lenza 2013).

At the beginning of the twentieth century, with Law 36/1904, the matter of a space for the insane (which Law 36 called the manicomio) returned with renewed urgency, since Law 36 allowed for the involuntary hospitalization of those suffering from a mental disorder. ${ }^{2}$ The framework established by Law 36 lasted until the 1970s, when the very notion of mental disorder was called into question from a social perspective. Central to this later revision was the translation of Goffman's work. In his 1961 book Asylums (Goffman 1961), Goffman questioned the actual therapeutic effectiveness of mental hospitals, defining them as places of isolation and marginalization of madness from society, similar to prisons. Goffman's book was translated into Italian by Franco Basaglia and his wife, Franca Ongaro (Goffman 1968; see also Basaglia 1968), who were also chiefly responsible for the founding of the Psichiatria Democratica movement and for the Italian reform of psychiatric health care in 1978-the world-famous Law 180 of May 13, 1978 ("Accertamenti e trattamenti sanitari volontari e obbligatori”). The law brought about the closure of psychiatric hospitals and the creation of the Servizi di Igiene Mentale.

Law 180 should be read in relation to the Italian sociocultural context, which at the time was experiencing a strong progressive push. The year 
1978 came after Pasolini's death (1975) and the social upheavals of 1968 and 1977; inherited their revolutionary aspirations; witnessed the overcoming of neo-realism; stood in the midst of the years of lead, which were wearing Italy down with stragismo, ${ }^{3}$ terrorism, and the kidnapping of Aldo Moro; and ended the long stream of changes brought about in the wake of the economic miracle. ${ }^{4}$ In these years, Basaglia was one of the most recognizable protagonists in Italian cultural life. The Psichiatria Democratica movement accepted the challenge of overcoming the 200 -year-old debate on the ideal place to treat madness, abolishing Law 36, and bringing about the closure of manicomi, thus making Italy the only country in the world to have followed Goffman's recommendations nearly to the letter.

There is a strong parallel between the changes in the therapeutic approach to mental disorders and the abolition of the architectural psychiatric space. There is, that is to say, a profound relationship between culture, social vision, and thought in architecture.

Discussing how Foucault has influenced architectural culture is crucial to developing a better understanding of Law 180 and the shattering of the space of the asylum in the context of Italian 1960s-1970s culture. In these years, as I will argue shortly, several Italian intellectuals, chief among them Manfredo Tafuri, pursued a novel system of interpretation of architectural culture by embracing the teachings of the main exponents of the multifaceted current of French post-structuralism. Beginning with the avant-garde shattering of classical architectural codes to bring about a rupture with post-Fascist history, the architectural project was radically reformed. The anti-classicist and post-avant-garde code found a point of reference in the criticism of Fascist architecture (architettura littoria) and, by extension, of institutional architectural language (architecture at the service of institutions) tout court. ${ }^{5}$

In this context, the role that Venetian culture played at a national level is particularly relevant for two reasons. The first is that there is a background of cultural references in the city of Venice, where Basaglia was born and died. Secondly, because Venice has a key role in the application of a poststructuralist critical method to architecture through one of its main proponents, Manfredo Tafuri. The book Il dispositivo Foucault, edited by Massimo Cacciari, Franco Rella, Manfredo Tafuri, and George Teyssot (Cacciari et al. 1977), paints a picture of possible cultural connections among philosophers and historians of architecture, active in the IUAV in Venice (then the Istituto Universitario di Architettura di Venezia), as they unravel the connectioncentral to the shattering of the psychiatric space-between the interpretation of social history and its effects on the architectural dimension. 
In 1973, Tafuri published Progetto e Utopia, in which he developed the themes he had outlined in the article "Per la critica di una ideologia architettonica," published in Contropiano in 1969 (Tafuri 1969). In 1980, two years after Law 180 had passed, Tafuri published La sfera e il labirinto. Both texts found immediate international resonance and established a new methodology in the historical study of architecture. ${ }^{6}$

In the book Progetto e Utopia, Tafuri defines architecture as the "riorganizzazione pianificata della produzione edilizia e della città come organismo produttivo" (Tafuri 1973, p. 92). Architecture is therefore the instrument that the intellectual can use to get to the heart of urban realities, when these are considered as social realities. This is the extent of Tafuri's originality and political activism. As an instrument, architecture is split and falls into a crisis. The split is between, on the one hand, the piano (the project) - the planning that has to conform to laws, regulations, and ultimately, in Foucauldian terms, to institutional power; and on the other hand, the utopia - architecture's urge to contribute to the drive towards social change that was rife in the decades under scrutiny. Utopia consists of those social values that should correct the piano (that is to say, institutional power). The friction between the institutional plan and the political utopia forms the basis of Tafuri's criticism. The crisis of modern architecture is traditionally attributed to the totalitarianisms of the 1930s (Fascism, Nazism, Stalinism). Tafuri, instead, starts by considering architecture as a system of social production and organization, and thence explicitly links the crisis of architecture to the "riorganizzazione internazionale del capitale, l'affermazione dei sistemi di pianificazione anticiclica e la realizzazione del primo piano quinquennale sovietico" (Tafuri 1973, p. 124). Architecture, in attempting to reorganize these systems of production, clashes with its inability to entirely absorb reality. For this reason, the piano, from being a project, becomes a vision that translates itself into pure utopia: "l'architettura come ideologia del Piano è travolta dalla realtà del Piano, una volta che questo superato il livello dell'utopia sia divenuto meccanismo operante" (Tafuri 1973, p. 125).

The terms piano and utopia incarnate the contradictions in the ideological processes of social and architectural actions. Since, on the one hand, architecture is unable to become an operative reality and, on the other, the architect is unable to become an intellectual, architecture remains split between diving into reality and observing it from the outside. No solution to this crisis is available, other than incorporating the values 
of capitalism as architectural values and to initiating a process of commodification of architecture that ultimately makes it an object rather than an instrument.

For Tafuri, the only way out of this impasse is a Marxist critique of architectural and urban ideology, which entails the application of a Foucauldian rupture of discourse to architecture. Tafuri develops his method in La sfera e il labirinto, where he draws more explicitly upon French post-structuralism. "Il progetto storico," the first chapter of the book, discusses in particular his intention of deconstructing reality. History as a critical discussion of contemporary or past reality loses the sense of causal or finalistic mechanisms that characterized classic historiography. Traces of history are deconstructed in a series of fragments that become meaningful when they are read together from a new perspective. In this critical method of investigating reality, which we may call writing by differences, any connection between the elements of the discourse is mobile and aims to reveal the deeper link between what Foucault calls "things." In other words, it is an investigation of the underlying strategy of ideology or supremacy of the period in question; an attempt to overcome the "veil of Maya" ${ }^{7}$ of artistic phenomena to investigate the inner laws of reality and to define meaning through a phenomenological approach.

Tafuri's method draws upon Foucault's "Discourse on Language" in the Archaeology of Knowledge, in which Foucault, amongst other key developments, distinguishes between discourses that are "uttered" and those that are "spoken" (Foucault 1972, first edition 1971). Tafuri's "writing by differences" amounts to a method that enables us to reflect on the word and the thing as isolated monads, to find a new, previously undiscovered, truth. This emerges as a rupture in the discourse.

A telling demonstration of how Foucault's rupture of meaning translates into Tafuri's reading of the architectural space is to be found in Tafuri's analysis of Le carceri d'invenzione by Piranesi, ${ }^{8}$ which opens a chapter entitled "L'architetto scellerato: G. B. Piranesi, l'eterotopia e il viaggio" in La sfera e il labirinto. For Tafuri, Piranesi's Carceri represent what Foucault calls "heterotopia." According to Foucault (2005, p. XIV),

Heterotopias are disturbing, probably because they secretly undermine language, because they make it impossible to name this and that, because they shatter or tangle common names, because they destroy 'syntax' in advance, and not only the syntax with which we construct sentences but also that less 
apparent syntax which causes words and things (next to and also opposite one another) to 'hold together.' This is why utopias permit fables and discourse: they run with the very grain of language and are part of the fundamental dimension of the fabula; heterotopias (such as those to be found so often in Borges) desiccate speech, stop words in their tracks, contest the very possibility of grammar at its source; they dissolve our myths and sterilize the lyricism of our sentence.

In Tafuri's words, to describe Piranesi’s Carceri we could indeed

Invocare per tale ossessiva tecnica dell'assemblaggio, la definizione data da Foucault dell'eterotopia: là dove l'utopia consola - osserva Foucault coprendo 'città dai vasti viali,' l'eterotopia inquieta, minando segretamente il linguaggio, 'devastando anzi tempo la sintassi, e non soltanto quella che costruisce le frasi, ma anche quella meno manifesta, che fa tenere insieme (a fianco e di fronte le une alle altre) le parole e le cose.' Ma tale eterotopia non è anche quella delle ricostruzioni di una Venezia inesistente da parte di Canaletto? (Tafuri 1980, p. 56)

For Tafuri, Piranesi's Carceri link architectural and Foucauldian readings of space. The Carceri are claustrophobic and panoptic and represent the perfect metaphor for the psychiatric space which must be shattered. In "Lettura del testo e pratiche discorsive," published in Il dispositivo Foucault, Tafuri writes:

Nella Storia della follia Foucault dimostra chiaramente come il problema della reclusione del folle non fosse, nel tardo medioevo e fino al '600 circa, una pratica; che non esisteva una 'messa in discorso' della follia. Il linguaggio del folle veniva considerato sotto due angoli visuali completamente differenti: o come discorso irragionevole da censurare o come verità estrema alla quale chiedere profezie. Quindi il folle poteva circolare nella società. Dal momento in cui si va costituendo un linguaggio per la follia, questa 'costruzione' implica la messa sotto osservazione del folle, e, di conseguenza, la sua 'reclusione.' (Tafuri 1977, p. 38)

However, from a material point of view, a "language of madness" did translate into the shaping of the psychiatric space and, better still, into the elaboration of architectural prototypes that could answer the demand for marginalization advanced by society (or the institution). What distinguishes the approach of the 1970s from the thought inherited from the eighteenth and nineteenth centuries is the attempt to distinguish clearly 
the notion of cura from that of custodia. The psychiatric space is the place where the boundary between cura and custodia plays out.

The relationship between mental disorder and architecture in Italy was influenced by the French example from as far back as the Napoleonic era. The main point of reference was the psychiatrist Philippe Pinel, who was among the first to explore the possibility of treating mental disorders through a therapeutic approach that regarded the insane as patients to be healed rather than humans to be incarcerated (Pinel 1809).

Philippe Pinel's son, Scipion Pinel, envisaged, in 1836, a type of "therapeutic place" that could foster patients' mental health by means of contact with nature and farm work in the countryside, a strategy that could also be used as a form of social rehabilitation (Pinel 1836; see also Esquirol 1835). Twenty years later, in 1856, John Conolly developed in Britain the theory and practice of "no-restraint" asylums, abandoning mechanical forms of coercion such as chains and handcuffs. He also advocated for asylums to be immersed in nature, and built according to "open-door" layouts, in contrast to traditional locked-down ones. The typological reference was the "small village type" with separate wards close to each other, following the model of a large farm, where patients could work in the fields (Conolly 1856).

This architectural model was thought to play a therapeutic role by simulating a condition of freedom and normality through agricultural work. The layout was arranged in wards, with a clear separation between patients (according to gender, diagnoses, etc.) and an immersion in nature, so that inpatients could walk-in open-air spaces, as if they were in the countryside. Additionally, these spaces were grouped around a central area that could function as the administrative center but also as a space of control (at times visual) over inpatients and wards, possibly favoring a panoptic arrangement of buildings. ${ }^{9}$

Mental institutions were not to be planned as prisons or convents, but had, nevertheless, to be isolated, as convents were, and had to accommodate mechanisms of control, just as prisons did, while at the same time simulating freedom of movement in the belief that this could be beneficial to inpatients (see e.g. Tamburini et al. 1918). As Fabbrichesi (1926, p. 687) put it, “'cossichè [sic] se le costruzioni di un ospedale e di un manicomio, considerate da un punto di vista superficiale ed esterno, sembrano pressoché identiche in quanto si riferisce ai finimenti interni, e specialmente di certe parti, il manicomio presenta però sempre qualche affinità con le costruzioni carcerarie." 
To this extent, we can affirm that the manicomi are the concrete expression of a type of architecture thought as "programmazione, riorganizzazione pianificata e della città come organismo produttivo" (Tafuri 1973, p. 92). Mental institutions became the new paradigm of this architectural project, as they included from the outset the construction of public buildings of a functional but also social nature (for example, they were initially placed extra-moenia, outside the city walls, for both hygienic and social purposes). An example of this is the asylum of Santa Maria della Pietà in Sant'Onofrio, which Tamburini regarded as the perfect architectural incarnation of Law 36 (see Neri 2014). These formed part of an urban context but as small independent cities, completely self-sufficient, without any relationship with their wider surroundings. As such, they set the scene for a simulation of freedom (Fabbrichesi 1926, p. 672), ${ }^{10}$ highlighted by boulevards with trees, gardens, farmland, and the arrangement of wards. ${ }^{11}$ They were, in summary, independent of each other, to ensure light, air, and privacy (Tamburini et al. 1918, p. 549), inspired by the criteria of "semplicità" and "igiene" (Pagliani 1905). ${ }^{12}$

These architectural elements simulate objects from "everyday life," but they were metaphors for a society that is considered "other" from the common one. In this context, those instruments of the architectural language become, in a Foucaldian way, a practice of power. As Tafuri (1977, p. 37) put it,

Per Foucault, la pratica discorsiva significa la 'messa in discorso,' la messa in linguaggio, la costruzione del linguaggio come opposizione binaria, linguaggio ragionevole/linguaggio irragionevole. Quindi il linguaggio del sano e il linguaggio del folle come vanno analizzati? Appunto, come una pratica di potere. Pratica di potere che passa attraverso che cosa? Attraverso 'rotture.'

The "rottura," the rupture to which Tafuri refers in his understanding of the psychiatric space, is its isolation from the city-the way in which it is severed from the urban space to become a container of social marginalization.

The rural aesthetic condition and the institution's functionality also had to take into account the needs of medical staff, who needed to live close to the city. For this reason, asylums were built near city centers or to main routes (close to train stations, for instance), whilst maintaining the necessary distance to ensure isolation from the urban context. ${ }^{13}$ As Fabbrichesi (1926, p. 672) put it, 
Anzitutto l'appezzamento non dovrà essere troppo discosto da una grande città: però sempre sufficientemente lontano, così da impedire che i rumori della vita cittadina possano essere uditi nell'istituto di cura [...] Mancando una comoda comunicazione ferroviaria non si dovrebbero mai oltrepassare i tre chilometri, perché altrimenti diverrebbe troppo dispendioso procurare il bisognevole per l'istituto, e troppo gravoso, per gli impiegati e per i familiari pervenirvi dalla città e a questa ritornare. Quando invece i mezzi di comunicazione siano comodi e rapidi, allora la distanza potrà essere aumentata senza danno fino a 5 o 6 chilometri. Veramente deplorevole è il criterio seguito da alcuni, soprattutto nei passati tempi, di costruire manicomi all'interno della città, o nella sua periferia.

Asylums were also built close to cities to guarantee prompt hospitalization, as mental patients had to be carried to the asylum in ambulances, not by train or public carriage. The ideal distance was "un'ora di cammino" (Tamburini et al. 1918, p. 548). The result was an architectural project of isolation that envisioned a paradoxical participation of the asylum in the city, in conjunction with an active "forgetting" of its presence-the perpetuation of a condition of forgetting and alienation.

An urban asylum is an unacknowledged place, a negative utopia, outside the temporal and social dimension, and constrained in a dimension of suspended time. This is a time of waiting: a heterotopia to use Foucault's term. As Foucault (Foucault 1984, conference 1967) put it:

First there are the utopias. Utopias are sites with no real place. They are sites that have a general relation of direct or inverted analogy with the real space of Society. They present society itself in a perfected form, or else society turned upside down, but in any case these utopias are fundamentally unreal spaces. There are also, probably in every culture, in every civilization, real places - places that do exist and that are formed in the very founding of society - which are something like counter-sites, a kind of effectively enacted utopia in which the real sites, all the other real sites that can be found within the culture, are simultaneously represented, contested, and inverted. Places of this kind are outside of all places, even though it may be possible to indicate their location in reality. Because these places are absolutely different from all the sites that they reflect and speak about, I shall call them, by way of contrast to utopias, heterotopias.

Understood as heterotopias, urban asylums are places in which freedom exists, but only insofar it is isolated in a dedicated space where it is simulated, along with nature. Urban asylums are places in which the complexi- 
ties of a productive city are recreated without the negative aspects of real systems of production. They perpetuate a vision of altered and alienated normality, with the purpose of creating an artificial structure of suspension in order to treat mental disorders. Urban asylums are other places in which to relax the mind outside the real social context, recreating conflicts that are managed without individual responsibility, this being transferred to the director of the asylum.

The project was seemingly born out of a utopian dimension that, having clashed with a different human reality, becomes a place of "discontinuità nel tempo', interruzione di un certo ordine, brusca rottura all'interno dell'ordinamento del 'sapere', e - allo stesso tempo - luogo eterogeneo che si ritaglia, che si dispone sullo sfondo del continuum spaziale" (Teyssot 1977, p. 25). Heterotopia thus acquires a double-temporal and spatial-meaning.

Architecture becomes the instrument for the construction of an other urban space, where mental disorder is confined and isolated, and in which therapy has the double significance of exclusion and protection from and of society.

Yet from another point of view, the proximity of psychiatric hospitals to the city means that forgetting their existence is not entirely possible. It becomes a process of psychological repression, an experience of collective amnesia in relation to the individual inmate, but also in relation to mental disorder as an element of the social. Asylums are therefore urban spaces, created to confine a physical element of the city itself in a space of repression: they are architectural generators of forgetting, structures that produce alienation - the social estrangement of individuals that recognize themselves as other from themselves.

To fight this architectural space means therefore to fight a social reality. Within this framework, the "Basaglia law" can be understood as a cultural turning point, where a social urge, embodied in architecture, shifts in the 1970s to become the urge for an epistemological shattering of the architectural discourse itself as institutional experience.

The incarnation of the institution within the institutional place (as Goffman had already noted with regard to the specificity of the psychiatric space) creates a parallel between sociopolitical reflection (such as French post-structuralism) and architectural reflection (Tafuri), because it moves from the premise that politics shapes architectural language, and leads us to consider how the latter may in its turn influence politics. Apart from the psychiatric context, we could for instance think about the 
extent to which architectural institutionalization translated Nazism and Fascism into visual terms, but also about the experiences of American neo-Palladianism. In this link between politics and architecture, the fragmentation of knowledge-much like the fragmentation of the institution that was pursued in Italy and France-means also the destruction and fragmentation of the architectural space qua expression of a political and social language.

The application of Law 180 was ultimately delegated to the individual regions, creating diversity across Italy - to the point that the final abandonment of asylums followed different chronologies depending on the area. ${ }^{14}$ The process can be regarded as being completed in 1994, when the state imposed on regions the task of closing the last remaining Ospedali psichiatrici provinciali by the end of the year. ${ }^{15}$ The landscape that these projects and laws engendered is diverse (see Luciani 1999; Gruppo di coordinamento del Progetto Nazionale 'Carte da legare' 2010; Airoldi et al. 2013).

After Law 180 was passed, total institutions became fragments, "ruptures in the discourse" that mark the suspension of time (Foucault 1972, first edition 1971, p. 5). They became part of a process of collective amnesia that enveloped mental disorder as a subjective fact, and were a symptom of an inability to respond to mental disorder as a social fact. Forty years on from the passing of Law 180, these tales are now embodied in physical objects; they have become lacerated matter ${ }^{16}$ recalling the artifice of sublime urban ruins, ${ }^{17}$ but also offering a clear historiographical representation of culture in the 1970s.

The explosion and condemnation of the space has engendered today a condition of simultaneous oblivion and memory (Sorbo 2017). The relationship between memory and forgetting testifies to the evolution of civil society in abandoning psychiatric hospitals as an expression of totalizing institutions of social control. According to Nietzsche, forgetting is a necessary operation only when we assume that "the unhistorical and the historical are necessary in equal measure for the health of an individual, of a people and of a culture" (Nietzsche 1997, p. 63). "It is altogether impossible to live at all without forgetting," Nietzsche (1997, p. 62) concludes. Yerushalmi, following Nietzsche, speaks of a collective forgetting, in parallel to collective memory, as a process connected to generational transmission; that is, to the ability of each generation to be in their time, with the added awareness of being in the process of transmitting thought and social culture. As Yerushalmi (1996, p. 108) put it, 
When we say that a people 'remembers' we are really saying that a past has been actively transmitted to the present generation and that this past has been accepted as meaningful. Conversely, a people 'forgets' when the generation that now possesses the past does not convey it to the next, or when the latter rejects what it receives and does not pass it onward, which is to say the same thing. The break in transmission can occur abruptly or by a process of erosion. But the principle remains. A people can never 'forget' what it has never received in the first place.

With the historical detachment that comes with the passing of forty years, we can affirm that the decommissioning of psychiatric hospitals has engendered a rupture in this possibility of transmission, because the long and strenuous process of de-institutionalization has de facto stopped with the matter of things (i.e. architecture), without proceeding to an elaboration of the immaterial elements that are connected to collective awareness (e.g. the role of mental disorders, the histories of patients, the archives, the medical records, the lived lives). It stopped with the elements that embodied in architecture the discontent that stemmed from this failure of generational transmission, defining places and spaces (formerly) of madness as mutilated and silent spaces of alienation and forgetting. This entailed forgetting the inability to craft a social response to marginalization (an issue that is sadly contemporary) with solutions other than institutionalization. This forgetting might have also, in turn, engendered the absence of an alternative to family or private responses to madness.

The pervasive condition of physical and intellectual estrangement that surrounds this issue- even as it is embodied in the matter of things-has become memory. Spaces have become untimely memories of forgetting, they participate in the spirit of the place, they are the petites madeleines of a voluntary memory of things and of an involuntary memory of collective events and experiences. ${ }^{18}$

The place in which the relationship between memory and forgetting takes place is this physical and cultural encounter. The erasing of these places gives rise to an epiphany, to the very experience of amnesia. In this experience, there dwells the retrieved memory of the "rupture of discourse" of the revolutionary Italian identity of the 1960s and 1970s.

The post-structuralist deconstruction of the language of the institution has brought about the fragmentation of the psychiatric space in Italy, because this has become, in an unrepeatable historical moment of revolution, the symbol of exile, of social separation, of the alienation of individuals 
into what is other than the self. One of the slogans of the movement of Italian anti-psychiatry was "abbattere i muri:" walls are architectural elements; walls define the inside and the outside. In 1989 the Berlin Wall fell. Walls are the instruments of alienation, and to shatter walls is the revolutionary action par excellence of the past century.

Translated from the Italian by Alvise Sforza Tarabochia

\section{Notes}

1. Legge n.248 del 20 Marzo 1865 per l'unificazione amministrativa del Regno d'Italia. Allegato A. Legge "Comunale e Provinciale," art. 174, c. 10. See also Scartabellati (2001, p. 196).

2. Legge 14 febbraio $1904, n .36$, Disposizioni sui manicomi e sugli alienati: Custodia e cura degli alienati. Art. 1: "Debbono essere custodite e curate nei manicomi le persone affette per qualunque causa da alienazione mentale, quando siano pericolose a sé o agli altri e riescano di pubblico scandalo."

3. "Stragismo" is a particular period in Italy, between the 70s and 80 s of the twentieth century during which the uses of acts of terrorism aimed to cause instability in public opinion.

4. One of the best visual portraits of the Italian cultural context can be found in Marco Tullio Giordana's 2003 film La meglio gioventù.

5. The historian of architecture Bruno Zevi (1973) was the main voice of this critical approach.

6. For a more recent reading of Tafuri's historical method see Biraghi (2005) and Di Marino (2009).

7. "Veil of Maya" is referred to the theory of the philosopher Schopenhauer as a metaphor of subjectivity of the truth.

8. Giovanni Battista Piranesi's (1720-1778) Carceri d'invenzione are a series of sixteen engravings made between 1745 and 1750 .

9. See Bentham (1791). Panopticon here refers chiefly to the way the space was arranged rather than literally referring to Bentham's Panopticon, since according to this all inmates' cells should be built around a central tower from which everything was visible-an inspection house. Within the psychiatric space the use of dormitories served the same purpose. The similarity with prisons derives from the overlap of the role of surveillance in the psychiatric hospital with the punitive role of the prison space. This overlap corresponds with the ambiguity of roles between prison and asylum, and the ambiguity between surveillance and punishment-to put it in Foucauldian terms. From an ethical perspective, this ambiguity derives from considering madness as a form of divine punishment and thus the 
insane as sinners - an implicit assumption that pervades the conception of mental disorders well into the eighteenth century.

10. As Fabbrichesi (1926, p. 672) put it, "l'area deve essere sufficientemente grande, sia perché nell'indirizzo moderno prevale il criterio di costruzione del manicomio del tipo a villaggio con fabbricati sparsi: sia perché largo posto debbono trovare i giardini ed i cortili esterni frammisti ai fabbricati, per occupare gli alienati in libertà." See also Morachiello (1982) and Doti (2013).

11. Examples of ward-type institutions on the Italian territory are numerous; suffice it to mention the S. Onofrio in Rome, San Lazzaro asylum in Reggio Emilia, the Paolo Pini asylum in Milan, the Cogoleto psychiatric hospital in Genoa, the Bianchi psychiatric hospital in Naples, and the psychiatric hospital in Rovigo. For a comprehensive catalogue of the main former mental asylums in Italy see Airoldi et al. (2013) and also Fabbrichesi (1926, especially pp. 734-735) with the "Tabella XXVI. Specchio con le caratteristiche essenziali di alcuni tra i più importanti e più recenti manicomi provinciali italiani."

12. The ideology of simplicity and hygiene was brought to Italy by the program of hygienic reclamation of historical city centers promoted by the Agostino de Pretis government after the cholera epidemics in Naples in 1885. See Morachiello (1982) and Pagliani (1913).

13. For an overarching view and a systematic study of Italian asylums see Airoldi et al. (2013).

14. The 1998 "Relazione sullo stato di attuazione del processo di superamento degli ospedali psichiatrici e sulla tubazione del progetto-obiettivo tutela della Salute Mentale 1994-1996" reveals that by March 31. 1998 only six out of seventy-five psychiatric hospitals had been completely closed. In 1999, the text of the approval of the "progetto-obiettivo" Tutela della salute mentale, 1998-2000, reveals that "il processo di superamento degli ospedali psichiatrici, pubblici e privati convenzionati, fortemente sollecitato dalle ultime leggi finanziarie, può ritenersi avviato a conclusione, anche se con tempi e modalità differenti da regione e regione." See Luciani (1999).

15. Legge 23 dicembre 1994, n. 724, art. 3, c. 5 "Misure di razionalizzazione della finanza pubblica." Regions were required to decommission the former psychiatric hospitals by December 31, 1996, repurposing the buildings and facilities for the production of revenue to be invested towards the implementation of the "progetto-obiettivo" Tutela della salute mentale 1994-1996. This envisioned a vast plan for the creation of territorial structures for mental health: the Centro di Salute Mentale, the Servizio Psichiatrico di Diagnosi e Cura, the semi-residential facilities (psychiatric day hospitals and day centers), and finally the residential ones. Legge 23 dicembre 2000 n. 388 , art. 98, c.3 repeats that "'beni mobili e immobili 
degli ex OP già assegnati, o da assegnare alle aziende sanitarie locali o alle aziende ospedaliere destinate alla produzione di reddito, attraverso la vendita anche parziale degli stessi, con diritto di prelazione per gli enti pubblici, o la locazione" are to be invested in the "realizzazione di strutture territoriali in particolare residenziali, nonché di centri diurni con attività riabilitative destinate ai malati mentali in attuazione degli interventi previsti dal piano sanitario nazionale," also specifying that "qualora risultino disponibili ulteriori somme, dopo l'attuazione di quanto previsto dal terzo periodo del presente comma, le aziende sanitarie potranno utilizzarle per altre attività di carattere sanitario."

16. "lacerated matter" is a way to define the fragmentation of the objects and spaces in the psychiatric architecture following the abandonment of those places subsequent to the application of the Basaglia law in Italy.

17. One of these sublime urban ruins is the former Ospedale psichiatrico di Rovigo, built in 1906 in response to Law 36 and finally abandoned in 1997 (Sorbo 2017).

18. As Nora $(1989$, p. 15) put it, at the end of the last century, when the final blow to traditional balances was felt in particular in the disintegration of the rural world, memory appeared, with Bergson, at the center of philosophical thought; with Freud, at the core of the psychological personality; and with Proust, at the heart of literary autobiography. We owe to Freud and to Proust those two intimate and yet universal sites of memory, the primal scene and the celebrated petite madeleine. The transformation of memory implies a decisive shift from the historical to the psychological, from the social to the individual, from the objective message to its subjective reception, from repetition to rememoration. The total psychologization of contemporary memory entails a completely new economy of the identity of the self, the mechanics of memory, and the relevance of the past.

\section{REFERENCES}

Airoldi, Cesare, et al., eds. 2013. I complessi manicomiali in Italia tra Otto e Novecento. Milan: Electa.

Babini, Valeria. 2011. Curare la mente: Dall'universo manicomiale al "paese di Basaglia". In Storia d'Italia. Annali. 26: Scienza e cultura dell'Italia unita, ed. Francesco Cassata and Claudio Pogliano, 623-651. Turin: Einaudi.

Basaglia, Franco. 1968. L'istituzione negata. Turin: Einaudi.

Bentham, John. 1791. Panopticon or the Inspection-House. London: T. Payne.

Biraghi, Marco. 2005. Il progetto di crisi: Manfredo Tafuri e l'architettura contemporanea. Milan: Editore Marinotti.

Cacciari, Massimo, et al. 1977. Il dispositivo Foucault. Venice: Cluva Libreria Editrice. 
Conolly, John. 1856. The Treatment of the Insane Without Mechanical Restraints. London: Smith Elder \& Co.

Crippa, Maria Antonietta. 2014. Storiografia e nuovi usi per gli ex ospedali psichiatrici in Italia. La rassegna degli archivi di Stato n. s., a. X: 51-59.

Di Marino, Orlando, ed. 2009. Manfredo Tafuri: Oltre la Storia. Naples: Clean.

Doti, Gerardo. 2013. Il manicomio, la città, il territorio: Un capo di relazioni transitorie. In I complessi manicomiali in Italia tra Otto e Novecento, ed. Cesare Ajroldi et al., 29-38. Milan: Electa.

Esquirol, Jeanne Étienne Dominique. 1835. Mémoire historique et statistique de la Maison Royale de Charenton. Paris: Chez Paul Renouard.

Fabbrichesi, Renato. 1926. Stabilimenti sanitari. II. Manicomi. In Manuale dell'architetto per cura dell'architetto ing. Daniele Donghi, vol. II, La composizione architettonica. Parte prima. Distribuzione. Sezione terza, ed. Daniele Donghi, 667-746. Turin: Utet.

Foucault, Michael. 1972. The Discourse on Language. In The Archaeology of Knowledge. Trans. Alan Sheridan, 215-237. New York: Pantheon.

- 1984. Des espaces autres, Conference at Cercle d'études architecturales, 14 Mars 1967. Architecture, Mouvement, Continuité 5: 46-49.

- 2003. The Birth of the Clinic: An Archaeology of Medical Perception. Trans. Alan Sheridan. London/New York: Routledge.

- 2005. Order of Things: An Archaeology of Human Sciences. London/New York: Routledge.

- 2006. History of Madness. Trans. Johnathan Murphy and Jean Khalfa. London/New York: Routledge.

Goffman, Erving. 1961. Asylums: Essays on the Social Situation of Mental Patients and Other Inmates. New York: Anchor Books.

- 1968. L'istituzione totale: Meccanismi dell'esclusione e della violenza. Trans. Franca Ongaro Basaglia. Turin: Einaudi.

Gruppo di coordinamento del Progetto Nazionale 'Carte da legare.' 2010. Primo rapporto sugli archivi degli ex ospedali: Ministero per $i$ beni e le attività culturali. Direzione generale per gli archivi. Servizio II-Archivi non statali. Salerno: Gaia.

Lenza, Cettina. 2013. Il manicomio Italiano nell'Europa dell'Ottocento: Gli esordi del dibattito e la questione di modelli. In I complessi manicomiali in Italia tra Otto e Novecento, ed. Cesare Ajroldi et al., 15-38. Milan: Electa.

Luciani, Domenico, ed. 1999. Per un atlante degli ospedali psichiatrici pubblici in Italia: Censimento geografico, cronologico e tipologico degli 'asili' pubblici italiani al 31 dicembre 1996, con aggiornamento al 31 ottobre 1998. Treviso: Fondazione Benetton Studi Ricerche.

Morachiello, Paolo. 1982. I congegni delle istituzioni: Ospedali, manicomi e carceri. In Italia Moderna: Immagini e storia di una identità nazionale, I. Dalla Unità al nuovo secolo: 1860-1900, ed. Oscar Calabrese, 169-193. Milan: Electa.

Neri, Maria Luisa. 2014. Storia, tutela, valorizzazione dei complessi manicomiali nei territori centro-italiani. La rassegna degli archivi di Stato n. s., a. X: 29-41. 
Nietzsche, Friedrich. 1997. Untimely Meditations. Trans. Reginald John Hollingdale. Cambridge: Cambridge University Press.

Nora, Pierre. 1989. Between Memory and History: Les Lieux de Mémoire. Representations (26): 7-24.

Pagliani, Luigi. 1905. Trattato di igiene e di sanità pubblica: Colle applicazioni alla ingegneria e alla vigilanza sanitaria. Vol. 1, Dei terreni e delle acque in rapporto colla igiene e colla sanità pubblica. Milan: Francesco Vallardi.

- 1913. Trattato di igiene e di sanità pubblica: Colle applicazioni alla ingegneria e alla vigilanza sanitaria. Vol. 2, Degli ambienti liberi e confinati in rapporto colla igiene e colla sanità pubblica. Milan: Francesco Vallardi.

Pinel, Pinel. 1809. Traité médico-philosophique sur l'aliénation mentale ou la manie. Paris: Imprimerie de Feugueray.

Pinel, Scipion. 1836. Traité complet du régime des aliénés, ou manuel des établissemens qui leur sont consacrés: Avec des Planches explicatives. Paris: Mauprivez éditeur.

Scartabellati, Andrea. 2001. L'umanità inutile: La questione follia in Italia tra fine Ottocento e inizio Novecento e il caso del manicomio provinciale di Cremona. Milan: Franco Angeli.

Scotti, Aurora. 1984. Malati e strutture ospedaliere dall'età dei Lumi all'Unità. In Storia d'Italia. Annali 7: Malattia e medicina, ed. Franco Della Peruta, 233-296. Turin: Einaudi.

Sorbo, Emanuela. 2017. La memoria dell'oblio: Ex Ospedale Psichiatrico di Rovigo. Venice: Marsilio.

Tafuri, Manfredo. 1969. Per la critica di una ideologia architettonica. Contropiano 1: 31-79.

-1973. Progetto e utopia: Architettura e sviluppo capitalistico. Bari: Laterza. - 1977. Lettura del testo e pratiche discorsive. In Il dispositivo Foucault, ed. Massimo Cacciari et al., 37-45. Venice: Cluva Libreria Editrice.

- 1980. La sfera e il labirinto: Avanguardie e architettura da Piranesi agli anni '70. Turin: Einaudi.

Tamburini, Augusto, Giulio Cesare Ferrari, and Giuseppe Antonini. 1918. L'assistenza degli alienati in Italia e in varie nazioni. Turin: Utet.

Teyssot, Georges. 1977. Eterotopie e storia degli spazi. In Il dispositivo Foucault, ed. Massimo Cacciari et al., 23-36. Venice: Cluva Libreria Editrice.

Yerushalmi, Yosef Hayim. 1996. Jewish History and Jewish Memory. Washington, DC: University of Washington Press.

Zevi, Bruno. 1973. Il linguaggio moderno dell'architettura. Turin: Einaudi. 


\title{
Doctor in Slaughter: Emilio De Rossignoli's Dialectic of Enlightenment
}

\author{
Fabio Camilletti
}

In the 1970s, and particularly in Italy, reflection on concentration camps moved from the sphere of historical testimony to that of biopolitics in the contemporary age. That is to say, alongside viewing concentration camps as historically determined experiences, and belonging to specific regimesprincipally that of Nazi Germany-camps were regarded as paradigms, albeit extreme ones, of the governance of bodies in technicized societies. ${ }^{1}$ Consequently, other structures of power and confinement-prisons, asylums, factories, but also schools, hospitals, and barracks - started being compared to the camp, in that it came to embody a state of exception and arbitrary power. In particular, it deliberately employed alienating strategies in order to induce depersonalization and prevent dissent, to the point of making it unthinkable. In this chapter I will focus on Lager dolce lager (henceforth Lager), a dystopian novel published in 1977 and set in an undetermined future that is dominated by a dictatorial regime. The author of Lager was Emilio De Rossignoli, an Istrian journalist who, after the war and the Istrian-Dalmatian exodus, moved to Milan, where he led a parallel life as an editor for ladies' magazines and as a crime fiction

\footnotetext{
F. Camilletti $(\bowtie)$

University of Warwick, Coventry, UK

e-mail: F.Camilletti@warwick.ac.uk
}

(C) The Author(s) 2019

A. Diazzi, A. S. Tarabochia (eds.), The Years of Alienation in Italy, https://doi.org/10.1007/978-3-030-15150-8_3 
writer under a pseudonym (Boschini et al. 2018). By reconstructing the troubled editorial history of De Rossignoli's novel, I will show how it crosses crucial moments and strains of 1960s and 1970s Italian culture: the debate on the "banality of evil" as the long-term aftermath of Hannah Arendt's essay of 1963; the aforementioned biopolitical take on camps; the presence of Nazi camps in late-1970s Italian cinema, following the popularity of Liliana Cavani's Il portiere di notte (1974) and Pier Paolo Pasolini's Salo, o le 120 giornate di Sodoma (1975); and the inquiry into power, control, and repression in the years of lead. Initially titled Dottore in strage, De Rossignoli's novel preceded the films of both Cavani and Pasolini, in a sense heralding their powerful reframing of problematic notions such as free will, responsibility, the relationship between power and violence, and evil. After being refused by mainstream publishers, Lager appeared in 1977 in a minor science fiction series, which severely prevented it from making an impact on Italy's broader audience: it remains, however, a largely original and telling work, which needs to be reinstated in the debate of that time.

In particular, I will focus on the way in which De Rossignoli's novel narrativizes the metamorphosis from victim to executioner as a process of progressive descent into alienation. Physical seclusion, the meticulous segmentation of the hours of the day, and, at the same time, the loss of coordinates for calculating the passing of time, the self-referentiality of camp tasks, its jargon, and ultimately its very existence, are all factors contributing to the protagonist's breakdown, at the same time offering a powerful allegory of why reason is not an antidote to the barbarism of camps, but rather its condition of possibility. Therefore, intentionally echoing the title of Max Horkheimer's and Theodor W. Adorno's ground-breaking study of 1944, I will speak of De Rossignoli's dialectic of enlightenment: a cultivated man, a "doctor" (as other characters often call him), the protagonist of Lager falls, precisely because of his commitment to resist the alienating experience of the camp, literally becoming a "doctor in slaughter" and ultimately loving the lager and the shelter it offers from the traumatic experience of the real.

Lager was published in Milan by Ennio Ciscato in 1977. The aim of the title was evidently to capitalize on the so-called Nazisploitation aesthetics, that is, the reemergence of Nazi-related imaginary in popular films after the mid-1970s, following the success of Cavani's Il portiere di notte and Pasolini's Salò (Whitechapel 2003; Magilow et al. 2011). At the same time, published as the eighteenth volume of the series 
"Gamma: I capolavori della fantascienza," and complemented by a cover picture in an allegorical style that was completely unrelated to its content, the novel was explicitly labeled science fiction. ${ }^{2}$ The back cover reinforced this aspect, mentioning De Rossignoli's science fiction novel of 1965 h come Milano: "Nella fantascienza si è cimentato con $H$ come Milano (Longanesi), tradotto in diverse lingue e particolarmente apprezzato dalla critica francese che ha paragonato il libro a L'isola del dottor Moreau di Wells e l'autore a Ray Bradbury (L'Express)." ${ }^{3}$ In the introduction, the series editor, Valentino De Carlo (in De Rossignoli 1977, p. 3), tried to create a link between these two aspects, locating the novelty of De Rossignoli's work in its bridging of Nazisploitation aesthetics and the potential of social critique that is peculiar to the science fiction genre: "Nonostante l'inconsueta ambientazione (un lager nazistico, ma non nazista...) [...] è un perfetto e tecnicamente nuovo romanzo di fantascienza. Sempre che per fantascienza non si voglia intendere i soliti omini verdi a esclusione di ogni altra speculazione narrativa nella mente e nel futuro dell'uomo."

Arguably, however, Lager dolce lager was neither initially thought of as science fiction, nor bore such a title during its gestation. An exchange of letters now held in the archive of Erich Linder's literary agency shows how De Rossignoli had since 1974 tried to allocate a manuscript with the working title of Dottore in strage (Preianò 2014a), which can plausibly be identified with an early version of Lager dolce lager (Camilletti 2014). On July 7, 1974, Linder had offered the book to Mario Spagnol, who at the time was head of the book division of publisher Rizzoli. Spagnol had asked literary critic Sergio Pautasso for a review, and Pautasso had contacted Linder on December 12, sending the manuscript back and saying: "La prossima settimana gliene parlerò, anche se non Le nascondo che sono un po' imbarazzato"' (quoted in Preianò 2014a). What was embarrassing about such a novel? As Linder summarized to De Rossignoli himself, in a letter of December 16:

La Rizzoli, dopo molte tergiversazioni e molte lentezze, ha risposto di no a DOTTORE IN STRAGE, - risposta che, in verità, mi pare sia dovuta non tanto alla bizzarria del libro, e quindi alle perplessità sulla sua validità, quanto ai timori e alle esitazioni di fronte ad un romanzo in cui appare il Signor Indro Biagi che, nella sua duplice reale personalità, è troppo importante per la casa Rizzoli perché questa pensi di poter mettere a repentaglio il proprio successo editoriale attraverso un personaggio di immaginazione che irriterebbe i due personaggi reali. (Preianò 2014a) 
In its original version, therefore, De Rossignoli's novel satirized two of the most famous journalists of the time, Indro Montanelli and Enzo Biagi, who were both Rizzoli authors: this was evidently enough to discourage the publisher, which incidentally was also De Rossignoli's employer; at the time, he worked as an editor of Rizzoli's periodicals for women.

Still, although minimized by Linder, it is highly probable that the novel's "oddity" had at least played some part in the publisher's refusal. Submitted only three months after the release of Cavani's film (April 11, 1974), and a year and a half before that of Pasolini's Salo (January 10, 1976), Dottore in strage could easily be perceived as an untimely and outlandish literary object, which was unrelated to the surrounding literary and cinematographic scene. Not incidentally, at the time of welcoming it into his science fiction series, De Carlo needed to point out how the book had been written before the release of Il portiere di notte, lest anyone should blame De Rossignoli for being a mere follower of the Nazisploitation vogue: "A proposito della Cavani, devo testimoniare che, rispetto a De Rossignoli, non ha avuto, come sembrerebbe, neppure il merito della priorità. La prima stesura di Lager, dolce lager l'ho letta circa sei anni fa e la seconda, nata da alcune schermaglie a fioretto tra me e l'autore, ha riposato per quattro anni nel mio cassetto di pigro ex editore di fs" (quoted in De Rossignoli 1977, p. 5). It seems, therefore, that the book was born for a quite different audience than the "Gamma" series; and that, once refused by mainstream publishers such as Rizzoli, De Rossignoli finally agreed to have it appear in a collection that was largely distant from his original interests, moreover, with a title echoing the B-movies of those years (e.g. Lorenzo Gicca Palli's Liebes Lager, 1976; Sergio Garrone's SS Lager 5-L'inferno delle donne, 1976; and Luigi Batzella's Kaput Lager-Gli ultimi giorni delle SS, 1977).

Dottore in strage/Lager dolce lager can succinctly be labeled dystopian fiction. The epigraph specifies that "Questa sembra una storia di ieri, ma è una storia di domani": unlike many of its most obvious antecedents, however-primarily George Orwell's 1984 (1949) and Ray Bradbury's Fabrenheit 451 (1953)-De Rossignoli does not go into detail about the fictional universe in which the novel is set, instead adopting an intentional ambiguity in relation to all elements that are extraneous to the camp and its life. We ignore the country in which events take place, and which kind of dictatorial regime rules it; even its political orientation remains uncertain, although it definitely comes close to Fascism. ${ }^{4}$ As readers, we only have 
feeble glimpses of an external world in which the least manifestation of independence of thought is rapidly and inexorably punished:

Penso che una settimana fa era diverso: mi credevo importante. Avevo mangiato bene, ero sazio, soddisfatto, arrogante. Il portafoglio gonfio, le risate degli amici, l'atmosfera ovattata del locale, quasi fuori del tempo e della realtà.

'Lasciatemelo dire. La gabbia aperta non è un favore al canarino, ma al gatto. Bisogna prima di tutto essere furbi e forti per meritare la libertà.'

Ecco, questo ho detto. E poco alla volta, nella nebbiolina dorata che il vino ha rappreso intorno a me, mi sono reso conto che gli amici erano muti, innaturali.

L'ultima risata era ormai spenta e non portava echi.

Qualcuno si alzò in fretta, rovesciando una sedia. Allora vidi i due signori vestiti di nero, col distintivo d'argento sulle cravatte.

Si sono accostati e mi hanno messo le mani sulle spalle. ...

Dissero: 'Andiamo,' e basta.

Mi hanno portato al centro politico. (De Rossignoli 1977, pp. 7-8)

The entire novel is subject to a systematic strategy of defamiliarization, by which only the camp exists, with its monotonous rituals and its internal liturgies. The camp itself has no name, only a number ("Sull'insegna logora [...] si legge: Campo 17," De Rossignoli 1977, p. 7), and its internal topography is also defined through abstract toponyms and numbers, so as to intensify the impersonality and estrangement of the setting ("Nido numero 3," p. 10; “baracca 25," p. 16). Characters bear no identity: to camp authorities, they are known only by a serial number. Moreover, the protagonist/narrator, who also remains unnamed throughout the entire novel, and is only called "dottore," sometimes and ironically, by camp authorities, calls them by the nicknames that form the Lagersprache: Snoopy, Frate Tacchino, Lucignolo, il Piccolo Tamburino Romagnolo, Profumo ("nel lager," the narrator comments, "tutti devono avere un soprannome. I nomi si sentono e si dimenticano; quanto ai numeri, ripugna usarli. Così nascono con facilità i nomignoli, alcuni naturali, facilmente comprensibili, altri più contorti; altri ancora di difficile interpretazione, nati da chissà quali deformazioni astruse del pensiero," p. 51). Time is also expressed through the camp's internal and progressively uncertain chronology: chapters are numbered following the narrator's presence in the camp ("Un giorno," "Due giorni," "Tre giorni," "Una settimana," "Due settimane," "Un mese," "Sei mesi," "Un anno," "Un giorno 
ancora"), mirroring the slow dissolution of time coordinates within the estranging everyday life of the lager. By so doing, the reader is systematically deprived of every handhold that might be external to the totalizing context of the camp, undergoing a process of alienation that mirrors the narrator's own descent into folly and alienation.

This strategy was plausibly inspired by some antecedent, and most notably "a (now largely forgotten) French novel on the Nazi camps, Charles Rohmer's L'autre (1951), which had been translated by Einaudi in 1954 and published in the series I gettoni" (Gordon 2012, p. 135). As Gordon notes, Elio Vittorini's cover notes put precisely the novel's intentional vagueness in the spotlight, somewhat "anticipat[ing] the 1960s debate over Arendt's phrase the 'banality of evil' and the role of bureaucracy in the genocide." As a consequence, Rohmer's books mark a "shift in the status of the Holocaust and the camps from subject of first-person testimony to a flexible analogy, a tool and a test case for any understanding we might aspire to history and of the present" (pp. 135-136). Rohmer's L'autre is, in Vittorini's words, a "calm and mathematical" book: "Rohmer does not give us personal experience: the protagonist of his story does not even have a name, he is 'a man' [...] Through the eyes of this passive witness, this stranger, this 'other man,' we see the world and life of the executioners from top to bottom: a world - and this is the key of the book - that is monstrously similar to our own" (quoted in Gordon 2012, p. 136).

In other words, unlike, for example, what happens with Primo Levi's $\mathrm{Se}$ questo è un nomo (1946), the purpose of Rohmer or De Rossignoli (who, nonetheless, had been a prisoner in a German war camp) is not to give testimony of a historical tragedy, but rather to use the lager as a paradigm and a litmus test of human nature. ${ }^{5}$ De Carlo perfectly understands this aspect, when writing that Lager "non vuole essere un documento a posteriori ma una pre-denuncia, non [...] per questo meno sconvolgente per il suo richiamarci alla verità: i lager sono dentro l'uomo, non fuori [...]. La passività dell'uomo ai suoi molteplici 'mali oscuri' è tale che non puoi sapere fino a dove è vittima consenziente o carnefice involontario" (De Rossignoli 1977, p. 4). By portraying a cultivated, enlightened man who vainly tries to remain sane and to resist the alienating experience of the camp, Lager depicts an experience of alienation that goes beyond the sphere of concentration camps, extending to social structures as a whole.

De Rossignoli's protagonist is characterized by remarkable confidence in his own rationality: a few times, other characters call him "dottore," which is plausibly the reason behind the original title Dottore in strage. 
From the beginning, he swears not to be changed by the camp's monotony, and later makes a bombastic claim parodying the rhetoric of antiFascism. When another prisoner, Dente, asks why the camp authorities have it in for him, he replies:

'Perché sono un uomo libero e non riescono a piegarmi [...]. Perché la dittatura ha più paura delle teste che delle armi.'

Alza le spalle annoiato.

'Le teste si tagliano in fretta e gli uomini liberi diventano schiavi in poche sedute, se togli loro il pane, la mortadella, la ciccia. Forse basta anche di meno: la ragazza, la partita, il deodorante. Tu non conti niente e la spavalderia ti muore dentro, come un lumino senz'olio: la devi rimpiazzare con l'umiltà se ti preme la pelle.' (pp. 72-73)

Consequently, unlike Dente and the other prisoners, who submit to the camp's rules, by keeping their own mental sanity in exchange, ${ }^{6}$ the protagonist's rational mind is precisely the cause of his own breakdown. From this viewpoint, the novel can be understood as an allegorical dialectic of Enlightenment, showing how totalitarianism is not the product of irrationalist drives, but rather the accomplishment of the Western cult of reason. Slowly, albeit inexorably, the protagonist interiorizes the camp's rules and rituals, to the point of inverting the polarity between freedom and imprisonment. Such reflection (doubtlessly indebted to Orwell's notion of "newspeak" from 1984) is presented through a character named Spinato, a twelve-year-old boy who was born in the camp and has never known the external world. Spinato heralds a new kind of human for whom freedom is not only a chimera but has even become unthinkable:

Il mondo che egli descrive è, a tratti, peggiore di quello in cui viviamo o cerchiamo di vivere, ma ha sprazzi sublimi. È ancora un lager, ma in una dimensione diversa, una specie di paradiso dei lager, dove si può mangiare a sazietà la sbobba di sempre, sentire la musica e accarezzare un pigro cane fedele. Nei sogni di Spinato ci sono molte cose viste e sentite, però mai le cose astratte come la gioia e la libertà perché nessuno è riuscito a spiegargliele. Per lui la libertà è un pensiero proibito, un peccato oscuro da schiacciare ai confini della coscienza, una malattia vergognosa di cui gli altri soffrono ma che non si nomina. [...] Neanche il sole è libero perché tramonta ogni sera nella stessa buca della terra, con scarlatti conati agonizzanti. [...] La libertà è la prigione vasta e orribile che circonda il lager e ne spia il quieto respiro programmato. [...] È l'esca che attira la volpe fuori dal rifugio 
dove non è sicura né protetta. Nei sogni di Spinato il pericolo è sempre oltre il reticolato. Povero Cappuccetto Rosso che vive sempre tra i lupi e ha terrore della nonna, là fuori. Per la sua giovane età, Spinato ha il permesso di entrare e di uscire dal cancello d'ingresso senza che una guardia l'accompagni; non va mai più lontano dell'infermeria. (pp. 151-152)

Spinato's fantasies herald the inversion of values experienced by the protagonist at the end of the novel. The regime has fallen; guardians are being executed, while the protagonist's companions leave the camp one by one; the "patrioti" who have dethroned the previous regime are about to vacate the camp for imprisoning their own opponents ("rizzano le forche senza accorgersi che non ce n'è bisogno: bastano quelle di prima per continuare a impiccare. La guardia è cambiata, ma non il carcere"' p. 221). The protagonist, however, tries desperately to remain:

Li vedo soltanto quando mi sono intorno, con le loro divise verdi, ancora incomplete, ma prossima alla perfezione liturgica. I distintivi sono mutati, ma restano d'argento.

'Sbrigati. Non ci sei che tu qui, ormai.'

Non rispondo, non li guardo nemmeno, chiuso nella preghiera.

'Deve essere rimbambito dalla fame. Portiamolo via.'

[...] Mi sbattono oltre il cancello, che si chiude implacabile dietro di me. Aggrappato al filo spinato, senza badare agli aculei che mi straziano la carne, grido: 'Mentite! Non lo distruggerete mai. Avete ancora bisogno del lager.'

Non voglio andare via. Scuoto il reticolato, frenetico. Il sangue mi cola dalle dita lacerate; le spine segnano di un rosso diadema la mia fronte.

Domando singhiozzando ai volti irridenti dei farisei che mi circondano: 'Maledetti, che cosa mi offrite in cambio?' (p. 222)

It is certainly possible (and Mario Spagnol must have read it this way) to define such a conclusion through the label of qualunquismo: the liberating army no different from its opponent except for its badges, and all political regimes need camps. ${ }^{7}$ It is more productive, however, to read Lager within the context of the broader reflection on alienation, confinement, and exclusion that was pursued in 1960s and 1970s Italy. As Gordon points out, two works of the early 1960s-Volponi's Memoriale (1962) and Calvino's La giornata di uno scrutatore (1963)—exploited the Nazi camp as an extreme paradigm of social structures of repression and control, whereas Volponi's novel focused on a worker's descent into paranoia within an "alienating factory setting" (Gordon 2012, p. 134), Calvino 
explored the setting of the Cottolengo hospital in Turin as a way of interrogating the relationship between norm, deviance, and social exclusion. De Rossignoli's h come Milano came out only two years after Calvino's novel, employing the state of exception created by an atomic explosion as the presupposition for challenging the resistance of social boundaries:

In $H$ come Milano un uomo senza nome [...] si muove tra le macerie di una Milano distrutta dalla bomba atomica. Non importa chi l'abbia sganciata o perché: ciò che importa è sopravvivere, in un mondo in cui i superstiti sono regrediti a uno stadio di barbarie, dandosi al saccheggio e al cannibalismo. La bomba ha sovvertito le gerarchie sociali: gli immigrati meridionali che abitano le periferie si sono organizzati in bande, i travestiti uccidono le donne per fare parrucche dei loro scalpi. In questo mondo alla rovescia, nessuno è salvo: nemmeno il narratore, che pure ha cercato fino all'ultimo di mantenere saldo il proprio raziocinio, e che forse proprio per questo finisce per divorare una ragazza, sopraffatto dalla follia che l'ha fatto regredire a uno stadio primitivo, autenticamente vampiresco. I milanesi ammazzano al sabato, diceva Scerbanenco: ma cosa accade quando uno stato d'eccezione come la bomba $[\ldots]$ trasforma ogni giorno in un sabato, un carnevale esasperato in cui ogni cosa diventa possibile? (Camilletti 2018, pp. 62-63)

Lager takes these same concerns to a further level, through the adoption of similar textual strategies (first and foremost the first-person mode, enabling a defamiliarizing identification between reader and narrator). At the same time, it comes close to the "neo-Enlightenment enquiry" into structures of oppression that pervades Italian culture from the mid-1970s onwards, including the anti-psychiatric movement of Franco Basaglia, the "genealogy of the oppression of women" reconstructed by Giuliana Morandini, Carlo Ginzburg's studies on the persecution of heretics, witches, and Jews, and most of all Leonardo Sciascia's reflection on Alessandro Manzoni's Storia della colonna infame (Gordon 2012, pp. 134-135). Although De Rossignoli did not personally share the ideological premises of such a broad movement of emancipation-in his article in the magazine Settimo giorno he praised life in the army, ${ }^{8}$ and a passage in his 1981 novel Concerto per una bambola openly ironizes on the Basaglia law, which had been approved three years earlier-his reflection comes particularly close to that of Sciascia, ${ }^{9}$ particularly because the latter "brings into focus the functioning of official, bureaucratic process; its power to silence and distort victims leading to hideous suffering; and its application by 'ordinary', upstanding citizens, who as individuals allow themselves to 
torture, corrupt and execute innocents, in some sense knowingly" (Gordon 2012, p. 135). Like $h$ come Milano, mirroring the slow metamorphosis of an enlightened, cultivated, and rational man into a cannibal, who kills and eats a girl for his survival, Lager shows the slow process by which a victim may become an executioner in his turn, precisely in that he relies on reason as the dividing line that keeps the individual away from barbarism.

Moreover, like Sciascia, De Rossignoli moves from Manzoni in order to articulate his own critique of social structures. The intertextual memory of Manzoni deeply pervades his oeuvre, from $h$ come Milano (in which the bomb makes the city sink into a state of exception in which social norms are subverted, as the plague did in I promessi sposi and Storia della colonna infame), to Concerto per una bambola, explicitly a romance novel "for ladies" that, however, surreptitiously conjures Manzoni's work to crafty readers: in driving near the Vetra square, in the centre of Milan, the "severa mole di San Lorenzo Maggiore" brings back to a character's mind "terribili storie di delitti e di esecuzioni” (De Rossignoli 1981, p. 56).

In Lager, the memory of Manzoni resurfaces in the camp's legends. The camp has a library made up of confiscated books; still, before making them available to prisoners, censors mutilate them heavily. Censorship "non toglie di circolazione i libri, ma li mutila fino all'irriconoscibile, lasciando frontespizio e indice, oltre qualche brano superstite, simile a un rottame galleggiante dopo il naufragio" (De Rossignoli 1977, p. 95). The same process takes place in the mind of prisoners, who are unable to perceive the intertextual - that is, literary-echo of what they imagine takes place at night, while they are intent upon saying the rosary:

Snoopy interrompe il birignao. 'Sentite la carretta?'

Tutti tacciono di colpo, tesi e spauriti, mentre Dio svanisce. È la radice di un'altra leggenda (loro non sanno quanto autentica) che narra di una carrozza nera la quale attraversa il lager nella notte per prelevare a domicilio un predestinato. Qualcuno afferma di averla vista. A cassetta, il Postiglione è avvolto in un tabarro sfrangiato che ricorda le ali chiuse di un pipistrello. Dicono che sia un internato, salvato tanti anni fa dalla cenere per diventare l'Olandese Volante dei forni.

Ascolto con gli altri l'eco delle ruote che vibra, si attenua e scompare.

'Per questa volta si fermerà altrove,' dice Snoopy.

Il cocchiere con la falce ha scelto una baracca diversa per invitare qualcuno alla festa di mezzanotte. (pp. 164-165) 
The legend is born out of the impossibility of voicing the truth-namely, that there are prisoners who actively collaborate with the camp's authorities in betraying their fellows and eliminating them (and the narrator knows that it builds on truth in that he is one of them). ${ }^{10}$ Consequently, prisoners create a legendary reality, bearing, however, interesting features of proximity with the fantasies created by the people of Milan in the worst days of the plague:

Tra le storie che quel delirio dell'unzioni fece immaginare, una merita che se ne faccia menzione, per il credito che acquistò, e per il giro che fece. Si raccontava, non da tutti nell'istessa maniera (che sarebbe un troppo singolar privilegio delle favole), ma a un di presso, che un tale, il tal giorno, aveva visto arrivar sulla piazza del duomo un tiro a sei, e dentro, con altri, un gran personaggio, con una faccia fosca e infocata, con gli occhi accesi, coi capelli ritti, e il labbro atteggiato di minaccia. Mentre quel tale stava intento a guardare, la carrozza s'era fermata; e il cocchiere l'aveva invitato a salirvi; e lui non aveva saputo dir di no. Dopo diversi rigiri, erano smontati alla porta d'un tal palazzo, dove entrato anche lui, con la compagnia, aveva trovato amenità e orrori, deserti e giardini, caverne e sale; e in esse, fantasime sedute a consiglio. Finalmente, gli erano state fatte vedere gran casse di danaro, e detto che ne prendesse quanto gli fosse piaciuto, con questo però, che accettasse un vasetto d'unguento, e andasse con esso ungendo per la città. Ma non avendo voluto acconsentire, s'era trovato, in un batter d'occhio, nel medesimo luogo dove era stato preso. (Manzoni 1840, pp. 618-619)

Supernatural imaginary - the coachman, inasmuch as the "Postiglione" of Lager is clearly the devil-poses the question of free will and responsibility in a state of emergency: ${ }^{11}$ can the prospect of individual benefit (the riches presented to the man from Milan by the devil; the advantages enjoyed by informers and Kapo in the camp's life) mean that one voluntarily harms one's fellow creatures? Nazi camps indeed proved that this is the case, as did the experience of the plague of 1630 in Manzoni's novel: not in the shape imagined by the people (the infamous untori, namely, those who intentionally spread the infection for a diabolic people), but in the safety measures and structures of exclusion by which political power-with the help of willing executioners-scapegoats and persecutes minorities in order to preserve consent. 
As previously discussed, Lager was largely ignored when it was published, and even later historians of Italian science fiction only cursorily mention it and $h$ come Milano as pioneering works that had no impact on the development of the genre. ${ }^{12}$ It seems, however, that-if a context for the production of the novel must be sought-it should rather be the progressive development of biopolitical consciousness that was deeply influenced in Italy by Marxism and by Marxist interpretation of social structures. Chronologically close to experiences such as the antipsychiatric movement, the debate on societal control, and Italo Mereu's work on inquisitorial trials, undertaken as a "contrappunto ideologico alla legislazione sull'emergenza degli anni di piombo" (Mereu 1988, p. vii), De Rossignoli's oeuvre, and Lager in particular, contribute to the dissemination of biopolitics-related themes among the broad audience of science and pulp fiction readers: the idea of camps extended beyond their historical existence, and were promoted as a paradigm for understanding the microphysical dimension of power; alienation as a characterizing feature of modernity; and the understanding of reason less as a rampart against barbarism and more as the condition of possibility for barbarism to reemerge. From this viewpoint, both $h$ come Milano and Lager need to be fully reinstated in the Italian canon as early examples of biopolitical novels, employing Manzoni's model in order to articulate a broader reflection on bare life and sovereign power, and, consequently, as a peripheral, albeit telling, example of the pervasiveness of biopolitical themes as a specific trait of Italian thought and culture (Esposito 2010).

\section{Notes}

1. This environment, among other consequences, paves the way to Giorgio Agamben's famous statement that "today is not the city but rather the camp that is the fundamental biopolitical paradigm of the West" (Agamben 1998, p. 181).

2. The series was published between 1976 and 1977, and featured works such as Robert A. Heinlein's Gulf (translated in 1976 as Vortice nero) and Isaac Asimov's The Naked Sun (Il sole nudo 1976). Iannuzzi (2014, pp. 17-18) makes clear how science fiction, for Italian readers, has historically been a question of paratext, so that science fiction is primarily what is labeled as such through specific editorial policies. 
3. I come Milano had been translated into French in 1967, as part of the prestigious Denoël science fiction series "Présence du futur," and was the first Italian novel to appear in it.

4. There are some clues that make us incline toward a right-wing, supremacist dictatorship. At the camp's entrance, we find a label expressing the same concept of the Nazi Arbeit macht frei at Auschwitz: "Il lavoro rende l'uomo libero" (De Rossignoli 1977, p. 7). In the chapter "Quattro giorni" (pp. 49-67) we find a succinct summary of the regime's policies: "i giovani che il regime ama e protegge devono professare l'ottimismo virile, frequentare le sezioni del partito, cantare alle adunate, dividere il tempo libero, dopo la scuola, l'officina e i campi, tra i passatempi leciti d'una sana ricreazione, come lo sport e, $[\mathrm{sic}]$ ancora meglio il tifo sportivo, il cinema ristretto al monopolio nazionale, la televisione di Stato, la pratica religiosa che permette di assorbire insieme precetti cristiani e comandamenti politici, trasformando il 'crescete e moltiplicatevi' in 'il numero è potenza'. [...] La famiglia e la stirpe si salvano col doppio matrimonio religioso e civile, con l'indissolubilità, con i premi di natalità e l'esenzione dalle tasse per chi ha più di cinque figli, perché la Nazione ha bisogno di tanti fieri soldatini da macellare in caso di santo conflitto. Non è ammesso il divorzio, sono vietati gli anti-fecondativi, tranne agli appartenenti alle razze inferiori che invece ne devono fare uso quotidiano. [...] Non si possono sposare, se non fra loro, negri, gialli, ebrei, zingari, pellerossa, esquimesi. Gli ebrei portano tatuata al polso la stella di Davide. [...] Dopo la pena di morte per colpe politiche, è stata ripristinata anche quella per i delitti comuni. Ai ladri recidivi viene mozzata la mano destra" (pp. 49-51).

5. In the camp of Libenau. As De Carlo writes, "il lager di De Rossignoli non è mediato, nasce da una esperienza ben altrimenti dolorosa, personale" (De Carlo quoted in De Rossignoli 1977, p. 4).

6. "Devi farti piccolo, scomparire, cercare che ti dimentichino. E quando ti cercheranno ancora, strisciare, supplicare, chiedere perdono, leccare tutti i piedi e tutti i sederi affinché rimandino l'impiccagione in programma, la tua. [...] Senti, siamo schiavi tutti, anche quando comandiamo, finché teniamo alla vita. Puoi sfidarli, batterli, umiliarli soltanto se non ti importa di morire. Ma per questo bisogna essere giovani [...] o vecchi saggi. Tu e io non siamo cosi”" (De Rossignoli 1977, p. 73).

7. It should, however, be noted that De Rossignoli was born in 1920 on an island in the Kvarner Gulf, today in Croatia: consequently, he had personally experienced the transition from the Fascist regime to the Yugoslavian one. His works testify to various degrees to his conservative and anti-Communist (but also anti-Fascist) views, which certainly did not contribute to his popularity in 1960s and 1970s Italy (Camilletti 2018, pp. 48-59). 
8. "Sono andato al C.A.R. di Casale Monferrato col proposito di vivere una giornata in caserma. Questa non era una novità per me; sono pochi gli italiani di quarant'anni che non hanno una esperienza militare e io non faccio eccezione alla regola. Ho prestato servizio di leva in un brutto periodo, durante la guerra. Per questo, quando sento parlare o leggo dei disagi e delle torture morali dei soldati d'oggi penso che chi parla o scrive sia in malafede. Non c’è niente di drammatico nella vita di caserma [...]. La caserma è una città, e neanche tanto piccola. Ha i suoi servizi, le sue scuole, i suoi laboratori, persino i suoi divertimenti. Nel suo genere, è una città modello, perché abolisce i privilegi fra i suoi abitanti e aiuta tutti, anche i meno dotati $[. .$.$] la caserma li aiuta con corsi d'istruzione obbligatori,$ tenuti da insegnanti borghesi. Molti soldati si trovano, così, a sedere per la prima volta sui banchi di scuola. In sei mesi non si possono fare miracoli, ma intanto imparano a leggere e a scrivere quel tanto che basta per tracciare la propria firma e per mandare due righe a casa. E le insegne dei negozi, i manifesti del cinema cessano di essere per loro un'accozzaglia di segni privi di senso" (quoted in Preianò 2014b). The article had been published in the magazine Settimo giorno on April 11, 1961.

9. "Con le nostre leggi, tutti i pazzi sono in libertà" (De Rossignoli 1981, p. 28).

10. "Voi potete trascinare al rogo milioni di eretici per difendere i dogmi della vostra fede invasata, ma prima o dopo, tra un minuto o tra un secolo, la pioggia di fuoco scenderà anche per voi. Forse, in qualche istituto chimico statale, stanno già riempiendo di cianuro la tua bombola, Gasista.' 'Sarà un gran bel giorno quando mi aiuterai, umile e zelante, a gasare i tuoi amichetti,' ribatte pacato. 'E accadrà'” (De Rossignoli 1977, p. 134).

11. De Rossignoli, the author of Io credo nei vampiri (1961), could also spot another possible incarnation of the coachman: the one driving Jonathan Harker to Dracula's castle in Bram Stoker's novel of 1897, witnessing a powerful cinematographic incarnation in Friedrich Wilhelm Murnau's Nosferatu (1922). In Murnau's film, the coach is the vehicle bridging civilization and barbarism, the natural and the supernatural, the domain of men and that of vampires, which is highlighted by the experimental use of special effects in portraying the ride. Renato Giovannoli (2008, pp. 44-48) has compared this scene from I promessi sposi to the figure of Dracula, thereby concretizing what remains only alluded in De Rossignoli's works.

12. Iannuzzi (2014) ignores De Rossignoli; his role, however, has repeatedly been reasserted, among others, by Vittorio Curtoni, Danilo Arona, and Giuseppe Lippi. 


\section{REFERENCES}

Agamben, Giorgio. 1998. Homo Sacer: Sovereign Power and Bare Life. Trans. Daniel Heller-Roazen. Stanford: Stanford University Press.

Boschini, Massimiliano, Fabio Camilletti, and Anna Preianò. 2018. L'uomo che credeva nei vampiri. Rome: Profondo Rosso.

Camilletti, Fabio. 2014. The Purloined De Rossignoli. Mattatoio n. 5. https:// www.mattatoio5.com/attualita/item/64-the-purloined-de-rossignoli. Accessed 19 Aug 2018.

-2018. Italia lunare: Gli anni Sessanta e l'occulto. Bern/Oxford: Peter Lang. De Rossignoli, Emilio. 1961. Io credo nei vampiri. Milan: Luciano Ferriani.

- 1965. h come Milano. Milan: Longanesi.

1977. Lager dolce lager. Milan: Ennio Ciscato Editore.

- 1981. Concerto per una bambola. Florence: Sonzogno.

Esposito, Roberto. 2010. Pensiero vivente: Origine e attualità della filosofia italiana. Turin: Einaudi.

Giovannoli, Renato. 2008. Il vampiro innominato: Il 'caso Manzoni-Dracula'e altri casi di vampirismo letterario. Milan: Medusa.

Gordon, Robert. 2012. The Holocaust in Italian Culture, 1944-2010. Stanford: Stanford University Press.

Iannuzzi, Giulia. 2014. Fantascienza italiana: Riviste, autori, dibattiti dagli anni Cinquanta agli anni Settanta. Milan: Mimesis.

Magilow, Daniel, Elizabeth Bridges, and Kristin T. Vander Lugt. 2011. Nazisploitation! The Nazi Image in Low-Brow Cinema and Culture. London: Continuum.

Manzoni, Alessandro. 1840. I promessi sposi: Storia milanese del secolo XVII scoperta e rifatta da Alessandro Manzoni. Storia della colonna infame. Milan: Guglielmini e Redaelli.

Mereu, Italo. 1988. Storia dell'intolleranza in Europa. Milan: Bompiani.

Preianò, Anna. 2014a. Dottore in strage: Il manoscritto perduto di Emilio De Rossignoli. Mattatoio n. 5, April 4. https://www.mattatoio5.com/attualita/ item/42-dottore-in-strage-il-manoscritto-perduto-di-emilio-de-rossignoli. Accessed 19 Aug 2018.

— 2014b. La libertà è un bene per vecchi: De' Rossignoli giornalista—prima parte. Mattatoio n. 5, August 31. https://www.mattatoio5.com/attualita/ item/59-la-liberta-e-un-bene-per-vecchi-de-rossignoli-giornalista-primaparte. Accessed 19 Aug 2018.

Whitechapel, Simon. 2003. Kamp Kulture: A History of Nazi Exploitation. London: Creation Books. 


\section{Workers at Olivetti}




\title{
Volponi-Ottieri-Olivetti and the Ills of Homo industrialis: Returning to a "Civiltà della natura" as a Questionable Antidote to the Urban-Industrial Malaise
}

\author{
David Albert Best
}

This chapter outlines how Adriano Olivetti's vision of progress was intertwined with his ideas for improving life among rural and agrarian societies, especially in southern Italy. Olivetti recognized the potential for cheap labor coming from the Mezzogiorno in the 1950s, but he was not insensitive to the causes of this explosion in out-migration from long-exploited farming regions, which risked much in gambling away their vital human resources to the industrialized North. In parallel to the exploration of Olivetti's writings on this theme, this chapter focuses on selected texts by two-time Strega winner Paolo Volponi, who nearly always set his work against a backdrop that was essentially rural or-explicitly or implicitlyeither the field of implementation of the Olivettian Comunità projects or the Olivettian factory. Hailed by critics as an "industrial writer" but equally poeta-contadino, Volponi never abandons the rural dimension in his

D. A. Best $(\bowtie)$

Free University of Brussels, Brussels, Belgium

e-mail: davibest@ulb.ac.be

(C) The Author(s) 2019

A. Diazzi, A. S. Tarabochia (eds.), The Years of Alienation in Italy, https://doi.org/10.1007/978-3-030-15150-8_4 
writing, even when his characters occupy the most urban and industrialized of spaces and livelihoods. Volponi could be said to represent the "other" side of industrial development looming in the shadows of the gleaming factory, the version less read, more painful and awkward to take in. The chapter will therefore look at some of this author's less-studied commentaries, together with his famous first two novels, alongside recently republished material by Olivetti that has not often been examined in a literary light. Thus another perspective is unveiled, reinforcing the view that though many plans have been made, projects launched, and foundations laid, it is arguable that no resolution has ever been found for the rural/urban dilemma that tore up much of the socioeconomic fabric of southern and rural Italy from the time of the economic miracle onwards.

The first fifteen years of Paolo Volponi's career, extending from the winter of 1949-1950 to 1965, comprised three indelible episodes in the writer's development: the beginning of his professional relationship with Adriano Olivetti; his initial fuga from the narrow vistas of Urbino, via Rome, to spend four years moving around the Abruzzi, Sicily, Calabria, and Basilicata; and his encounter here with the questione del Mezzogiorno and its meridionalisti. The period closes in a double climax with his debut novel Memoriale (Volponi 1962/1991), followed by the first of his two Strega-winners: the work that best embodies his manifesto for "industrialized" rurality, La macchina mondiale (Volponi 1965; Zinato 2002, p. LI). ${ }^{1}$

This period also encompassed the most intense transitional phase for the Olivetti enterprise on the world stage: healthy growth in Europe, North and South America, and South Africa was accompanied by a dramatic rise in productivity, exports, and employee numbers in manufacturing plants across Italy. By the end of the 1960s, Olivetti had eleven domestic industrial plants and ten abroad, and "[f]rom 1950 to 1961, Olivetti's export of typewriters grew seven times and export of calculating machines grew an amazing twenty-three times" (Onida et al. 2013, pp. 425-426, 434-435). In this context, the decade-and-a-half in question embraced a steep learning curve for the young and thus far inexperienced lawyer-author. Starting out as a factfinder-sociologist[-poet], he would soon become manager[-novelist] (Olivetti), and-later-consultant (Agnelli), parliamentarian (PCI; Rifondazione Comunista; Independent), then senator, not to mention his lifelong pursuit as an art collector.

Not born into a family of letters by any stretch, but of farming and artisan stock and the first in his family schooled beyond elementary level, 
Volponi did not go unappreciated by Olivetti. He had an authentic familiarity with the world of work, having observed it close at hand from his earliest years: "Vedevo nella mia città cosa facevano gli artigiani [...]. Vedevo immediatamente sotto le mura di Urbino $[\ldots]$ che cosa facevano $i$ contadini. Io avevo un'idea del lavoro e questo sorprese Adriano" (Zinato 2002 , p. XLIII). Neither pupil nor master would take their eyes off the role and values of contadini in an evolving society that only in part was advancing towards industrialized status. Both shared a sense of mission regarding sustainable approaches to the well-being of industrial workers who, in their droves, were leaving behind a "rural civilization" (Zagrebelsky 2014 , p. 26; Ochetto 2014a, pp. 11-13). As such, at the age of twentysix, Volponi was appointed the task of documenting "la realtà sociale del Paese" (Pistilli 2014, p. 17) and, later, of improving workplace conditions for Olivetti's manual workers (Pistilli 2014, p. 20).

For millions of Italians, the period 1950-1965 covered the most feverish and calamitous chapter in the miracolo economico, commonly understood to have peaked around 1958-1963. The political atmosphere was imbued with the notion that at last "l'Italia repubblicana si [era] lasciata alle spalle la nozione di paese contadino" (Lupo 2013, p. 9). This interval in Volponi's life featured some of his most profound experiences when-at Olivetti's behest-he was plunged into the socioeconomic fabric of remote, depressed, and historically repressed regions that were not only recovering from the destruction and hardship of World War II but also, more pertinently, from centuries of economic and socio-anthropological stagnation rooted in archaic labor and landholding patterns, subordination to rural landlords, "medieval" farming practices, and chronically substandard housing. It was a critical turning point when the immensity of hope for change seemed to fuel a heaving surge towards modernity, the scale of which had rarely been seen in Italian history. Corrado Stajano, soured by hindsight, describes a kind of stillbirth of the modern Italian nation, characterizing the period as "anni di speranza, nel nome di un'Italia che doveva nascere e non nacque, a partire proprio dal Mezzogiorno con il suo carico di dolore e di morte" (Stajano 2014, p. 20).

For Volponi, the rural sphere was indeed characterized by "una forte condizione di dolore, $[\ldots]$ molto più dura che non la cosiddetta alienazione del mondo industriale" (Volponi 1980, p. 132). But what was behind this pessimistic reading of "pain and death"? Olivetti's interventionist endeavors in rural southern Italy came at a time when the Mezzogiorno narrative portrayed a scenario of bloody, bottom-up attempts at agrarian 
reform. The chronic disparities between, in Olivetti's words, "un Nord industrialmente progredito e un Sud straordinariamente povero e depresso" were no longer tenable (Olivetti 2013a, p. 27). Yet the push for justice on the land, despite mutterings of endorsement across governing parties, involved hundreds of thousands of farmers campaigning in isolation: mere words of encouragement coming out of Rome without serious political backing. ${ }^{2}$ Sicily, Calabria, Basilicata, and the Abruzzi witnessed strikes, land occupations, and "work-ins," which provoked reprisals from estate holders and their armed guards or carabinieri, resulting in injury, arrest, and prison for not a few peasant protesters, and a number of fatalities: deaths by gunshot in Calabria (Melissa, October 1949) and Basilicata (Montescaglioso, December 1949); violent clashes across much of Sicily from January to March 1950 (Enna, Caltanisetta, Agrigento, Palermo, Messina); and in the Abruzzi (Fucino basin) in February 1950 (Ginsborg 1990, pp. 124-129).

Notwithstanding a vocal call from most quarters to break the status quo in southern Italy and a strong mandate to implement agrarian reform, together with unambiguous condemnation of absentee landlordism and the latifundia system, De Gasperi's administration achieved little against the obstructionism of land-owning elements within government: "in the eighteen months between their electoral victory of April 1948 and the killings at Melissa of October 1949 the DC had done absolutely nothing" (Ginsborg 1990, p. 129). But under mounting pressure from other parties, as well as the US Secretary of State, and wishing to avert the risk of further land-based violence on a national scale, reform-albeit piecemeal, region-based, and mostly signifying the expropriation of "unimproved" farmland-was eventually implemented. The amount handed over was chronically insufficient and usually involved the poorest and least workable land, while holdings were small, ranging from 3 to 30 hectares. The latter were split into inconvenient parcels distant from each other and were so fragmented that farming on this scale could never be viable. The release of land between 1948 and 1952 also led to a "land rush" among the southern Italian peasantry and a paradoxical hike in land prices (Ginsborg 1990, pp. 127-133). Clearly, it was too little too late to counter the hemorrhaging of unskilled labor towards the North.

Southern Italy experienced its "greatest ferment in the winter of 1949-1950" (Ginsborg 1990, p. 129), and it was precisely at this time and into the four regions listed above that Olivetti- on the United Nations Relief and Rehabilitation Administration-Comitato Amministrativo 
Soccorso ai Senzatetto, UNRRA-CASAS board of directors-sent Volponi on his first mission. Coming from a very different situation in Urbino and Montefeltro, whose relatively better-off rural populations knew little of the scale of destitution in southern Italy, Volponi's mandate concerned the study of the socioeconomic milieu, demography and human geography, the potential for labor supply and productivity, and the needs and wants of southern communities. Olivetti would bring his ideas for Comunità into this context in early 1950, especially in the form of an experimental agrarian settlement, Borgo La Martella, located in the plains just to the north of Matera. La Martella was developed to accommodate several hundred farming families extracted from 2472 of the most insalubrious Matera Sassi "cave dwellings" (by a De Gasperi government decree), ${ }^{3}$ and to decentralize some of the administrative functions of this regional capital (Pistilli 2014, p. 43).

\subsection{Matera: “Capitale del mondo contadino”}

When Volponi first set foot in Matera something like 50 percent of the population lived in the Sassi; the bulk of farm laborers walked tens of kilometers before dawn each day to reach their fields; and child mortality was soaring at around two in five. Crudely dubbed the "capitale simbolica del mondo contadino," Matera was garnering interest on the international scene, especially among American and German social anthropologists, in large part because of the attention it had received from Olivetti and from meridionalisti-cultural figures such as Carlo Levi and Rocco Scotellaro (Ochetto 2009, pp. 185-187). ${ }^{4}$ The UNRRA-CASAS mission from 1944 onwards was charged not only with rebuilding damaged and unsafe housing but also with supporting vulnerable sectors of society through initiatives to enhance productivity in agriculture and industry. Volponi explains Olivetti's interest in sustaining southern Italy, his “idea di un'Italia nuova, che partisse anche dal Mezzogiorno, dal suo carico di dolente storia e realtà" (as cited by Zinato 2002, p. XLVI):

Il progetto di Olivetti mirava alla ricostruzione non solo delle case, ma anche di un tessuto sociale ed economico (piccole cooperative agricole, botteghe artigiane, iniziative turistiche) per dare a quei luoghi, storicamente depressi e privi ormai di una loro cultura, una possibilità di autonomia. Per far ciò cercava qualcuno che studiasse questi territori e individuasse le loro capacità di sviluppo. (Volponi 1985, pp. 139-140) 
The "qualcuno" cited here would be Volponi, whose rural affinitiesApennine poet and voice of the Montefeltro peasants-are now well known. One might venture that his rural vocation (professional and poetic) took hold at Matera: primed by his ancestry in the Urbino hinterland which, at the time of his birth was "fatta interamente di mezzadri" (Zinato 2002, p. XXXIII), the roots were set for an evolving manifesto rurale that would accompany every step of his managerial, literary, and political maturation.

Olivetti laid the foundations for the development of farming communities adjacent to their fields in a valley within sight of Matera, an early "Comunità" based on the integrated projects already functioning in the Canavese where, according to the industrialist, "[a]bbiamo portato nuove fonti di lavoro in paesi di montagna, ridando nuova vita a villaggi impoveriti e sfiduciati, abbiamo incoraggiato in molteplici forme dirette e indirette il sorgere di numerose cooperative di agricoltori, abbiamo portato nuovi stabilimenti là dove la crisi è più dolorosa" (Olivetti 2013a, p. 44). As a field-based settlement of between two and three hundred farming families (now saved hours-long daily treks), La Martella was an attempt to convert the expropriated latifundia into sustainable cooperatives supported by essential services, including a library and a theatre, fostering conditions that would allow for industrial-style production systems. Manuela Pistilli documents Volponi's involvement in this post-World War II “incubator" for transforming southern Italian agriculture:

L'obiettivo - con l'apporto di urbanisti, sociologi, economisti, ecc. - era quello di dare ai contadini del luogo centri abitati completi di tutto e non solo: biblioteca, chiesa, centro sociale, cooperative, macchine agricole e nuovi programmi di coltura. [...]. In quel periodo della sua vita lo scrittore partecipò a quel progetto di riforma agraria, uno dei primi importanti del Mezzogiorno che seguì molto da vicino, realizzando insieme ad altri gli studi su Matera come presupposto all'abbandono dei Sassi. (Pistilli 2014, p. 45)

For Volponi, the Matera initiatives were genuine attempts to put a sustainable development plan in place in southern Italy, "territoriale, urbanistico che fosse anche insieme un programma di sviluppo economico, di ripresa culturale e rilancio di tutta una società" (Pistilli 2014, p. 44). Set against the cultural backdrop of Levi's Cristo si è fermato a Eboli, La Martella became "il simbolo delle ingiuste condizioni di vita dei contadini meridi- 
onali a cui occorreva dare una risposta" (Fabbri et al. 1994, p. 75). It was also an effort to set a bulwark against the inexorable tug of northern factories, which was sapping the southern Italian economy of its most vital resource, a youthful labor force.

However, it did not quite function as foreseen: one of the key players in the Martella project, Ludovico Quaroni (architect and urban planner), concedes that " $[\mathrm{n}]$ on abbiamo compreso che, una volta sradicati dai Sassi, gli abitanti non avrebbero resistito al richiamo della grande fabbrica del nord, l'avrebbero preferita alla cooperativa contadina o alla piccola industria locale che d'altra parte tardavano a venire" (Ochetto 2009, p. 197). Indeed, not only were the UNRRA-CASAS programs for southern Italy poorly implemented by Rome, they also suffered from localized corruption and cronyism. Volponi would subsequently complain that beyond the immediate need for homes, "nessuno in sede politica ha mai considerato [...] [i] discorsi anche sulle risorse, sulle qualità, sulle tendenze, sulle possibilità di quelle zone" (Ochetto 2014b; Pistilli 2014, p. 130). What is more, the attraction of ready money, hence a liberation from centuries-old cycles of adversity and conservatism; the emancipatory status of a factory job; and the chance to share in the gains produced by capitalist growth were reasons too strong and numerous for a population that had struggled through centuries of indigence and toil to hang on for yet more utopian promises from well-meaning intellectuals and meridionalisti. Valerio Ochetto sums up:

Il silenzio è caduto sulla Martella non perché l'ipotesi comunitaria fosse debole culturalmente, ma perché è stata battuta da una volontà politica egemone e antagonista. Era possibile salvare la specificità del mondo contadino, attuare una industrializzazione regolata, oppure il fenomeno della corsa al nord era storicamente scontato, come scontata l'industrializzazione disorganica e distruttiva del tessuto sociale del Meridione? (Ochetto 2009, p. 197)

Olivetti was profoundly disappointed by his project's failure, attributing it to the stalling tactics of the State, where the truths revealed were simply too compromising: "l'incomprensione ufficiale, o forse la paura, del valore dimostrativo che questo sperimento avrebbe avuto, si risolse in un vero e proprio ostruzionismo burocratico" (Ochetto 2009, p. 197). Volponi shared this disillusionment, laying the blame at the feet of the "poteri clientelari del Sud o comunque, governativi, pubblici, politici, anche accademici" (Ochetto 2014b, p. 128). Was it a grand intellectual illusion to 
aspire to keep the southern peasants on the land, based on American sociological concepts and the utopian thinking of Italian progressives who were, in any case, out of touch with the local reality? Olivetti was scathing against what he termed the "pseudointellettuali," whose pens had not yet spared "un solo uomo all'indigenza e alla tragica inquietudine di una vita senza lavoro" (Olivetti 2013a, p. 44).

Later critics, especially in Volponi's home region, echoed Olivetti's indictment: at a public hearing on the planned modernization of agriculture held at Isola del Piano (Pesaro-Urbino), rural activist Fausto Belfiori would rail against the "intellectual," "establishment" conception of progress: "Gli intellettuali, quali suggerimenti possono dare, loro che non hanno saputo far altro che oltraggiare, svilire, scardinare?" (Belfiori 1980, p. 109). This critic's diatribe scorned the received dogma of an "extinct" civiltà rurale, with its "epoca oscurantista sicuramente tramontata e un progresso definitivamente assicurato" (Belfiori 1980, p. 110). Recoiling at such fuzzy utopianism, he described the gulf separating "intellectuals" from the hard truth of rurality: "Né l'utopia né l'ideologia assicurano un domani al mondo contadino che deve respingere le subdole tecniche della propaganda $[. .$.$] . La realtà contadina, la civiltà contadina non è una fase$ superata dall'evoluzione sociale" (Belfiori 1980, p. 112). Volponi was also present at this debate and, always sensitive to the fate of "contadini," took the opportunity to extend his vision for Italian rurality. While admitting to being "mosso soprattutto da un senso di affetto," he asserted that his ambition was not so much to fix the status quo but, rather, to make a drive towards "un diverso modo di organizzare e di condurre le nostre campagne e la nostra agricoltura, nel momento in cui il nostro Paese si accorge che in questi trent'anni di sviluppo ha dimenticato l'agricoltura." The "progettista-visionario" Volponi, like a real-life Anteo or Gigler, denouncing agricultural policies that had been implemented with a "visione tecnica $[\ldots]$ vecchia di cento anni," would sketch out a future in which "l'agricoltura italiana possa tornare ad essere una protagonista forte della vita economica, sociale, culturale e anche politica del paese" (Volponi 1980, pp. 129-130). In opposition to Belfiori's entrenched stance, Volponi was an unswerving exponent of modern agricultural systems, generating capital and nurturing innovation, not the sort dictated by a ruling political elite but cultivated from within rural communities, among its own protagonists: illuminated figures like his progenies-of-art, the rustic thinker-inventors of his fiction. ${ }^{6}$ 
Volponi spoke out against the collective amnesia related to centuries of rural hardship in which "[1] a civiltà contadina o il mondo contadino era per molti aspetti anche poco civile, era pieno di dolore e di fatiche mostruose di analfabetismo di solitudine." Regarding the "extinction of the peasantry," he surpassed Belfiori's seemingly provincial pride to measure it in ideological terms as yet another manner in which the people of rural Italy had been subjugated by class-based self-interest: "La condizione del contadino non è una condizione naturale $[\ldots]$, ma è una condizione voluta da un certo tipo di organizzazione, dalla proprietà delle terre e di una società che su queste proprietà costituiva la sua forza e i suoi poteri: organizzandosi come società agraria conservatrice, opprimente, bloccata" (Volponi 1980, pp. 131-132). Insisting on the gains offered by technology, industry, machines, and now "intellettuali veri dell'economia e dell'agricoltura," Volponi put forward his project for revitalizing the countryside through mechanized farming and a cooperative political framework:

Bisogna organizzare le nostre terre in modo nuovo attraverso grossi e forti investimenti $[\ldots]$, per avviare la trasformazione della nostra agricoltura condurla in senso industriale pianificando sapendo cosa coltivare nelle zone secondo i consigli tecnici (degli intellettuali) e insieme dei contadini. [...]. [Le] macchine rendono oggi il lavoro meno faticoso ed è una fortuna che ci siano, ma è che quelle macchine devono diventare uno strumento più attivo di un rapporto che ci liberi anche dal potere che su quelle macchine hanno altri. (Volponi 1980, p. 133)

Not only do Volponi's comments appear to echo Anteo's project for La macchina mondiale, they also call to mind another of Volponi's protagonists, less known but as much a visionary, that is Gigler, hero of the short story "L'Acqua e il motore," Umbrian travelling salesman and jack-of-alltrades, kinsman to the marchigiano Anteo in his "passione per i motori e per la meccanica." What is more, Gigler "parla di progresso e della scienza che cambierà il mondo insieme con gli uomini” (Volponi 1981, p. 14). Penned as a film script (though never produced), the tale is set in the early 1900s in an impoverished hamlet, home to a handful of peasant families and located in the barren upper Tiber valley in the most northerly corner of Umbria. Gigler, whose practical nature and political intuition tell him what these isolated communities most need, concocts a motorized water pump. Conflict, protest, and struggle ensue, involving landowners, peas- 
ants from neighboring hills, and Gubbio townspeople. Guido Santato compares Gigler to Anteo: "Questo personaggio [che] 'parla di progresso e della scienza [...];' è dunque un antenato di Anteo [...], che progetta una trasformazione dei sistemi di produzione e dell'intera organizzazione sociale da attuarsi attraverso una sistematica applicazione della scienza, con particolare riguardo alla meccanizzazione dell'agricoltura." For both "progressive rebels," "[l]a fede nella scienza e nel progresso conferisce però una forte connotazione politica al personaggio: nel corso della vicenda l'ambulante-meccanico Gigler diviene un agitatore rivoluzionario," while Anteo declares an instinctive Marxist revolutionary affiliation (Santato 1998, p. 6).

Are these prototypical politics of rural development not analogous to the Olivettian notion of Comunità exported into the rural context, yet now no longer modeled on the factory but on farmland worked by machines and contadini-operai; mechanized, "industrialized" agriculture; "la fabbrica" in its ideal setting? Alessandro Moscè defines it as "[1]a macchina al servizio dell'uomo per un futuro tecnologico armonioso, $[\ldots]$, la provocazione di un profeta che intende rendere docile l'industrializzazione del paese, accertata la sua convenienza" (Moscè 2004, p. 53). Volponi[/ Anteo/Gigler] thus believes not only "nelle macchine e nel loro avvento," but also in "[l'] operosità dell'uomo e l'automaticità delle macchine per innalzare la qualità della vita” (p. 52). Olivetti’s words would also resonate with Volponi's Marxist vision of the "liberazione collettiva" depicted in his protagonists' struggles:

$[\mathrm{L}] \mathrm{a}$ moltiplicazione di sempre più complessi ed esatti apparati di automazione, sta avviando l'uomo verso una nuova condizione di libertà e di conquiste. [...]. [T]occa una meta in cui direttamente si invera quello che penso sia l'inalienabile, più alto fine che un'industria deve porsi di operare, cioè, non soltanto per l'affermazione del proprio nome e del proprio lavoro, ma per il progresso comune - economico, sociale, etico - della intera collettività. (Olivetti 2013b, pp. 121-122)

Olivetti-with strains of Marxism-would tackle the question of farm machinery, too, which was conceived, he believed, "per servire l'uomo, per liberarlo, col frutto della sua stessa fatica, dall'antica fatica di alcune più dure e inerti prove, per dargli altro campo d'affermare la sua vocazione di costruttore" (pp. 121-122). Are we not under the spell of Anteo's “world machine" treatise, Volponi's rural manifesto? At Isola del Piano, the writer 
underscored the detrimental falsity of conservative nostalgia, not without a healthy dose of self-irony, insisting on his outline for a "new rurality":

Una ripresa viva e vera del mondo contadino e non soltanto per le nostalgie $[\ldots]$ che in fondo santificano i contadini nella loro fatica, lasciamoli per sempre nella loro posizione come oggetti da museo, ma anche nella loro condizione disumana di fatica, di espropriazione di emarginazione. Fissi al loro posto; che socialmente è una condanna, mentre l'intellettuale che li ha ammirati e cantati, per qualche giorno, può passare altrove e manovrare le sue iniziative per esprimere e cantare, per fare i suoi libri e le sue ricerche. (Volponi 1980, p. 133)

It is thus a much embittered Volponi who later elucidates the sorry fate of Olivetti's Martella:

Si trattava di far cessare la dipendenza secolare dei contadini dal grande centro urbano da cui partivano all'alba, per andare a lavorare un pezzo di terra, lontano, nella pianura sterminata, secca, priva di alberi, desolata da anni, e a cui tornavano alla sera per abitare in case malsane, insieme al mulo, alle galline, al porco. Si volle tentare con l'apporto di urbanisti, sociologi, economisti, di appoderare la campagna, di portare i contadini in centri progettati completamente ex novo da architetti, completi di tutto, dalla biblioteca, alla chiesa, al centro sociale, alla cooperativa, con macchine agricole, nuove sementi e nuovi programmi di coltura. [...]. Ma niente di tutto questo si riuscí $[s i c]$ a realizzare perché sapeva di socialismo, di kolchoz, di cooperativa rossa. (Volponi 1985, pp. 139-140)

No matter how alienating the northern factories might subsequently become for workers of peasant origin, such a life would be deemed a lesser evil to the daily struggle of laborers up and down the length of Italy. Luciano Gallino explains:

Il fatto che dalle valli canavesane le persone premessero da ogni dove per venire assunte alla Olivetti, pur possedendo dei terreni, oltre a delle case in condizioni migliori rispetto ad altre parti d'Italia - penso alle povere case dei contadini delle valli cuneesi, o del delta padano, o di Matera - è di per sé una prova che quel lavoro alle presse conteneva certo componenti di faticosità $\mathrm{e}$ di alienazioni rilevanti, ma era 'meno peggio' del lavoro che si lasciava alle spalle. (Gallino 2001, pp. 50-51) 
It is among Volponi's less prominent writings that the abandonment of these types of landscapes in the marginal upper Marches is most excruciatingly depicted. His study of peasant habitations in the Mercatello (PU) area, "Per Case dell'alta valle del Metauro," bears testament to the utter squalor and hopelessness of rural place and society in this era of "progress":

$[\mathrm{N}]$ ere nella miseria e nel dolore di una grande ingiustizia, sono le case delle frazioni contadine [...], crudeli campi montani, percorsi di fatica, solitudine, aridità e gelo. I contadini abitavano queste case dalle $[s i c]$ metà del millennio e anche prima, al riparo come belve: senz'acqua, senza luce, senza fuoco, con pochi attrezzi, senza mobili, senza stoviglie né corredi. (Volponi 1997, pp. 2-3)

Other examples can be found in "L'acqua e il motore:" "Le case del nostro racconto sono fra le più lontane cadenti e povere; i poderi tra i più alti e scoscesi sono faticosi e rendono poco [...]. Le famiglie sono poverissime e attonite $[\ldots]$, si raccolgono al tramonto dentro i tuguri scuri affumicati e percossi da tutti i venti. Gli arredi sono miserrimi e scarsi" (Volponi 1981, p. 11). Pistilli concludes that the acceptance of factory life could only be "meno peggio" in comparison:

[S]i trattava di contadini legati a un'economia che imponeva loro 'fatiche gravose' per lavorare i campi sprovvisti di adeguate attrezzature meccaniche. Quindi risulta evidente come per la popolazione contadina la fabbrica rappresentasse indubbiamente nell'immaginario collettivo una panacea: un lavoro sicuro e ben retribuito. Questo è anche ciò che nella finzione accade al personaggio di Memoriale, Albino Saluggia, il contadino reduce dalla guerra e dalla prigionia, che lascia il suo paese natio Candia per andare a lavorare in una grande fabbrica del nord, convinto del fatto che questa sia una buona opportunità offertagli dal destino. (Pistilli 2014, pp. 97-98)

\subsection{Alienation in Industry ANd the Factory: Not Only an URban Ill}

Not only was the rural sphere integral to Olivetti's vision of progress in the districts close to his home in the Canavese but also in [rural] southern Italy. It was both the source of raw labor and a place of pain connected, at first, with centuries of exploitation and manipulation and, then, veritable wound bleeding its youth and vitality in a one-way flow, first to North and South America, as well as to Australia, Belgium, France, Switzerland, and 
West Germany (Ginsborg 1990, p. 211), and then towards the northern Italian cities and their hinterlands: industry, "growth," "modernity," "emancipation." Today, in Italian rural communities, the scars are tender where the wounds are not still festering. ${ }^{7}$ Such is the sociohistoric context and perennial backdrop to Volponi's writing: despite being deemed an 'industrial writer' (though he disdained the epithet pinned on him by Vittorini and Calvino), his characters and scenes are seldom without their rural dimension. Indeed, this component constitutes the inglorious reverse side of industrial development.

Moving towards a conclusion, an image from a Volponi masterpiece, Memoriale, serves to crystallize the problematic notion of "returning to a peasant way of life" presented in the title. Olivetti and the "intellettualiartigiani industriali" in his employ, particularly Volponi and Ottieri, persistently echo a tradition going back to Virgil where they contemplate a return to "la civiltà della natura" as a palliative cure for the malaise brought on by the urban-industrial transformation of societies, and the work patterns, habitats, and lifestyles to which such change led. But this "remedy," a tragic and ironic panacea, is simultaneously shown up as being neither a happy nor timely one: instead, it reveals the poignancy of failure, the crushing sense of loss, forever, of that apparently simple [but misremembered] bucolic world of pastoral values; in its place lies a terrible void. The factory and the modern city, Volponi and Ottieri tell us, will never accept and allow the peasant way of life to perpetuate or evolve in its own way, but will irrevocably distort the peasant, along with his/her values and memories.

The epitomizing scene from Memoriale (set out below) emphasizes Volponi's “industry:" alienation, work, and society as being inseparable from considerations of the rurality that imbue his protagonists' daily lives and psyches with a deep-seated regret and sadness. The same can be perceived in Olivetti's writing: 'Ai lavoratori' (Olivetti 2012), addressed to Pozzuoli workers and artfully cited by Ottieri to illustrate the gulf between peasants and the industrial era in his Donnarumma all'assalto (Ottieri 2004, pp. 116-118), painfully testifies a recognition of the brusque "evolution" of industrial work patterns for those wrenched from their "ruralnatural" origins and the subsequent hemorrhaging effect inflicted on those places: "L'uomo, strappato alla terra e alla natura dalla civiltà delle macchine, ha sofferto nel profondo del suo animo e non sappiamo nemmeno quante e profonde incisioni, quante dolorose ferite, quanti irreparabili danni siano occorsi nel segreto del suo inconscio" (Olivetti 2013b, 
pp. 102-103). The idea is reinforced in Ottieri's frequent descriptions of displaced characters, ill at ease in and around the city and its factories, better placed in dilapidated or half-built peripheries, within sight, smell, sound, and touch of the earthier perimeter of Milan, especially through the eyes of the protagonist, Emma, in Tempi stretti (Ottieri 2013; Lupo 2013, pp. 17-18; Di Maio 2014, p. 26).

In this conclusive scene from Memoriale, Albino laments the passing of his peasant heritage and the soulless factory life that has taken its place. Most of all, he muses on what could have been had he remained a "contadino":

Se avessi fatto il contadino e fossi rimasto a Candia, pensavo, non mi sarei ammalato. Avrei potuto comperare altra terra, prendere un trattore e mettere su una stalla. Avrei potuto vivere per conto mio e decidere ogni giorno il mio lavoro libero per i campi. Le stelle segnano le stagioni e si sa quando seminare, rivoltare la terra, mietere e tagliare i fieni. Le piogge gonfiano i semi e aprono i solchetti al sole che viene dopo. Avrei potuto cambiar strada dietro una lepre o risalire i fossi del confine. Scuotere gli alberi da frutta o sedermi a dare una voce a quelli degli altri campi. Fare un lavoro mio, completamente; risparmiare, scegliere le scorte, la legna, i mangimi. Lasciare le cose per l'inverno; usare poco i soldi. Invece ho accettato il lavoro in fabbrica. [...]. Lavorare a ore, un minuto dietro l'altro, una mano dietro l'altra, una schiena dietro l'altra, nelle grandi officine. Dipendere da altri, senza nemmeno conoscerli ed essere confuso tra tutti gli altri. Tutti i conforti della fabbrica diventano alla fine, [...], dei motivi di pena. (Volponi 1962/1991, pp. 152-153)

His soliloquy epitomizes the dilemma faced by all those who leave their place of origin and by society (today's no less so) in dealing with this multifaceted question.

Olivetti's attempts to implement his conception of community came during a phase of industrialization that was dominated by centre-left governments but characterized by "una sorta di 'supplenza' di un'azienda privata alla carenza pubblica in un territorio montano e agricolo come Ivrea, dove l'industrializzazione è avvenuta miracolosamente senza sradicare i contadini dal loro orto" (Zinato 2002, p. XLIX). It defined Olivetti's role as "engaged" industrialist, concrete and not utopian, "autentico riformatore, per temperamento e per intima convinzione, intellettuale e morale" (Ferrarotti 2013, p. 18). But not everywhere was like Ivrea, with its ethics of work, collaboration, and solidarity, and blessed by the atten- 
tions of one of its most progressive citizens. Hence, while Olivetti's "communities" filled lacunae in state-sponsored development plans and appear to have met with success in specific areas, little was achieved in southern Italy but further fragmentation of society, not only owing to the pull and push factors determining out-migration (Ginsborg 1990, pp. 210-253), but also to other more primal influences aptly depicted by the psychologist in charge of hiring new workers in Ottieri's Donnarumma all'assalto:

L'industrializzazione del mezzogiorno come fatto della questione meridionale, cioè della questione loro, li lascia indifferenti; li insospettisce. Per i nobili è una cafoneria. Per i contadini, i quali verso notte s'aggirano scalzi intorno alla casa fra le viti, lungo la campagna arida a terrazze, per i sentieri segnati dai fichidindia, o si rinchiudono nelle grandi case rettangolari sulla Statale, essa non è che un grande pranzo, di cui prendere qualche briciola [...]. In questa zona industriale, l'industria vive arroccata, goccia nel mare o nella sabbia di una civiltà di pescatori senza barca e di contadini senza terra. (Ottieri 2004, pp. 150-151)

In what seems like a losing battle, Volponi makes his bid to industrialize agriculture and rurality, ${ }^{8}$ even going so far as to assert the need for a revolutionary Faculty of Agrarian Studies in Urbino to breathe life into rural communities and economies, to stay the outflow (Volponi 1995, pp. 90-92).

But to this "ruralism," industrialists (and politics) juxtaposed the northern factory. What were unskilled peasants to do? Olivetti's speeches of the time dovetail with Volponi's two novels from his Ivrea period, Memoriale and La macchina mondiale, and with Ottieri's Tempi stretti and Donnarumma all'assalto. Each illustrate core Olivettian concerns-shared by each protagonist-particularly on the nature of interaction between workers, the factory, and the city, played out as reflections on the troubled city-periphery spaces occupied by some of those displaced "former peasants." In a candid letter to Pasolini, dated November 9, 1956, on a dark theme later elaborated in Le mosche del capitale (Volponi 1989), Volponi decried his own condition alongside those working in the factory: "Intanto lavoro dentro un ufficio di vetro, tra piante insipide che sembrano vivere di corrente elettrica; tutta la stanza vibra tesa, percorsa da sottili e insistenti messaggi, da colori e nichel come un'anticamera della sedia elettrica" (Volponi 2009, p. 43). It is another jarring portrait of the industrial worker who has lost all sense of mission, ranging from the lowest to the highest 
echelons of factory life. It would be witnessed by Ottieri, too, in Pozzuoli, yet this writer rhetorically tempered his colleague's observation by noting, in a statement made in 1966, the worse fate befalling those who remained as peasants: "Chi è convinto che gli uomini odierni siano pazzi per gli uffici di vetro e i tubi di distillazione, fa male a credere che si stia meglio in campagna" (Fontana 2013, p. 373).

Volponi's observations on the rural sphere throughout his literary, political, and professional career do more than enough to strengthen Ottieri's point. His antiheroes, Albino and Anteo-unreliable narrators perhaps, or just perennially hypersensitive and at risk of delusional burn out-contribute amply to troubling the issue. Volponi's seemingly bucolic bid to salve the malaise of the factory "nella fuga verso un improbabile ritorno alla civiltà della natura" (Lupo 2013, p. 14) fails to deliver any definitive solution to the ills wrought by northern factory-bound emigration, but instead gives us a glaring insight into the socio-anthropological crisis that leaders of the time should have addressed by heeding and investing in the Olivetti initiatives.

\section{Notes}

1. Volponi won the Strega a second time with La strada per Roma (Volponi 1991).

2. Volponi's sustained attack on Rome's "establishment" approach to La questione meridionale can be witnessed in his speech to the Italian Senate on November 6, 1984), "Per una civile unità nazionale: La questione meridionale," delivered in reaction to the enactment of draft legislation, "Conversione in legge del decreto-legge 18 settembre 1984, n. 581, recante norme urgenti per la prosecuzione dell'intervento straordinario nel Mezzogiorno" (Volponi 2013, pp. 37-48).

3. Legge "Risanamento del rione Sassi nell'ambito del Comune di Matera" n. 619 del 17 maggio 1952.

4. Matera's "peasant capital" title was purportedly documented first by University of Arkansas scholar, F. G. Friedmann (Ochetto 2009, pp. 185-187).

5. Respectively, protagonist of the novel La macchina mondiale (Volponi 1965 ) and hero in the short story "L'acqua e il motore" (Volponi 1981), taken up in subsequent paragraphs.

6. "Farei torto alla mia cultura, prima ancora che alla cultura meridionale," states Volponi to the Italian Senate on November 6, 1984, "se pensassi che 
qualcuno di Roma sia in grado di risolvere i problemi dei siciliani o dei napoletani” (Volponi 2013, p. 48).

7. Contemporary novelist and reportage writer, Angelo Ferracuti (Fermo 1960) and poet-novelist, Francesco Genitoni (Cola 1952) both provide more recent amplifications on this theme.

8. On the politics of rurality, see Roberto Esposti and Franco Sotte (1999, pp. 29-55).

\section{REFERENCES}

Belfiori, Fausto. 1980. Untitled Presentation. In Intellettuali e realtà contadina: Studi e ricerche per una nuova società, 1973-1980, ed. Gino Girolomoni, 109-113. Isola del Piano/Urbania: Comunità Montana del Medio Metauro/ Provincia di Pesaro e Urbino.

Di Maio, Fabrizio. 2014. Ottiero Ottieri: Un caso letterario. Rome: Carocci.

Esposti, Roberto, and Franco Sotte, eds. 1999. Sviluppo rurale e occupazione. Milan: FrancoAngeli.

Fabbri, Marcello, Laura Muratori Fabbri, Leonardo Sacco, and Luigi Za, eds. 1994. Dall'utopia alla politica: Autonomia locale e rinnovamento della politica meridionale nell'esperimento comunitario. Rome: Fondazione Adriano Olivetti.

Ferrarotti, Franco. 2013. La concreta utopia di Adriano Olivetti. Bologna: Edizioni Dehoniane.

Fontana, Mattia. 2013. La fabbrica d'irrealtà. In Ottieri, O. Tempi stretti, 361-386. Matelica: Hacca.

Gallino, Luciano. 2001. L'impresa responsabile: Un'intervista su Adriano Olivetti. Turin: Comunità.

Ginsborg, Paul. 1990. A History of Contemporary Italy: Society and Politics, 1943-1988. London: Penguin.

Lupo, Giuseppe. 2013. La fabbrica triste di Ottiero Ottieri. In Ottieri, O. Tempi stretti, 9-18. Matelica: Hacca.

Moscè, Alessandro. 2004. Luoghi del Novecento: Studi critici su autori italiani; C. Pavese, P. Volponi, T. Guerra, A. Bevilacqua, U. Piersanti. Venice: Marsilio.

Ochetto, Valerio. 2009. Adriano Olivetti. Venice: Marsilio.

- 2014a. Introduzione. In Paolo Volponi: Uno scrittore dirigente alla Olivetti di Ivrea, ed. Manuela Pistilli, 11-13. Fano: Aras.

- 2014b. Intervista a Paolo Volponi su Adriano Olivetti (1983). In Paolo Volponi: Uno scrittore dirigente alla Olivetti, ed. Manuela Pistilli, 121-137. Fano: Aras.

Olivetti, Adriano. (1954-1955) 2012. Ai Lavoratori: Discorsi agli operai di Pozzuoli e Ivrea. Rome/Ivrea: Comunità.

—. (1959) 2013a. Il cammino della Comunità. Rome/Ivrea: Comunità. 
(1959) 2013b. In Il mondo che nasce: Dieci scritti per la cultura, la politica, la società, ed. Alberto Saibene. Rome/Ivrea: Comunità.

Onida, Fabrizio, Giuseppe Berta, and Mario Perugini. 2013. Old and New Italian Manufacturing Multinational Firms. In The Oxford Handbook of the Italian Economy since Unification, ed. Gianni Toniolo, 417-454. Oxford: Oxford University Press.

Ottieri, Ottiero. (1959) 2004. Donnarumma all'assalto. Milan: Garzanti.

_. (1957) 2013. Tempi stretti. Matelica: Hacca.

Pistilli, Manuela. 2014. Paolo Volponi: Uno scrittore dirigente alla Olivetti di Ivrea. Fano: Aras.

Santato, Guido. 1998. Foreword. In Volponi, P. 'L'acqua e il motore: Film sull'Umbria', Studi novecenteschi 55 (XXV): 5-27.

Stajano, Corrado. 2014. Destini: Testimonianze di un mondo perduto. Milan: Archinto.

Volponi, Paolo. (1962) 1991. Memoriale. Turin: Einaudi.

- (1965) 1975. La macchina mondiale. Turin: Einaudi.

1980. Untitled Presentation. In Intellettuali e realtà contadina: Studi e ricerche per una nuova società rurale, 1973-1980, ed. Gino Girolomoni, 129-133. Isola del Piano/Urbania: Comunità Montana del Medio Metauro/ Provincia di Pesaro e Urbino.

—. (1981) 1998. L'acqua e il motore: Film sull'Umbria. Studi novecenteschi 55 (XXV): 5-27.

- 1985. Vi racconto una storia. Scuola e territorio 20: 139-140.

. 1989. Le mosche del capitale. Turin: Einaudi.

- 1991. La strada per Roma. Turin: Einaudi.

—. 1997. Per Case dell'alta valle del Metauro. l'immaginazione 143: 2-5.

- 2009. In Scrivo a te come guardandomi allo specchio: Lettere a Pasolini (1954-1975), ed. Daniele Fioretti. Florence: Polistampa.

- 2013. In Discorsi parlamentari: 1984-1992, ed. Paolo Giannotti and Laura Ercolani. Manni: San Cesario di Lecce.

Zagrebelsky, Gustavo. 2014. Introduction. In Olivetti, A. Le fabbriche di bene, 11-33. Rome/Ivrea: Comunità.

Zinato, Emanuele. 2002. Cronologia. In Volponi, P. Romanzi e prose II, ed. Emanuele Zinato, XXXIII-XXXLXV. Turin: Einaudi. 


\title{
"Sentirsi Scorticati Vivi." The Theme of Alienation in Ottiero Ottieri's Works
}

\author{
Fabrizio Di Maio
}

This chapter sets out to examine how Ottiero Ottieri (1924-2002) has represented alienation in his works. Considering that Ottieri suffered from a persistent depressive disorder, ${ }^{1}$ I will read his works in an autobiographical key, focusing especially on the mental aspects of alienation. Ottieri describes the symptoms of his chronic depression with the expression "feeling of unreality," which we can consider, I claim, a state of alienation or, more specifically, mental alienation. In particular, I will analyze how Ottieri has transposed elements from a medical or psychiatric context into a literary framework, giving alienation a central place in many of his autobiographical novels and poems. I will also examine three main recurrent features of alienation in Ottieri's works: depersonalization, dysmorphophobia, and distorted time.

As my analysis will be mostly based on autobiography, it is worth mentioning the critics who have highlighted the autobiographical aspect of Ottieri's writing. Giuseppe Pedriali defines Ottieri's writing as expression of “autobiografismo" (Pedriali 1995), while Paolo Milano draws attention to the mixture of "autobiografia e cronaca" (Milano 1962). I would suggest that we can also define his works as "trasposizione autobiografica"

F. Di Maio $(\bowtie)$

University of Birmingham, Birmingham, UK

e-mail: F.dimaio@bham.ac.uk

(C) The Author(s) 2019

A. Diazzi, A. S. Tarabochia (eds.), The Years of Alienation in Italy, https://doi.org/10.1007/978-3-030-15150-8_5 
and "bio-letteratura" (Di Maio 2014, p. 15) or, using Ottieri's own words "letteratura autocentrica."

Gaccione: 'Come definirebbe la sua letteratura?'.

Ottieri: 'Beh, per non dire autobiografica, che è un termine troppo usato, direi autocentrica. In fondo parlo sempre di me e delle persone che mi sono state vicine; c'è sempre un rapporto molto legato alla mia vita.' (Gaccione 2000 , p. 21)

Emphasizing the strong relationship between himself and his work, Ottieri constantly reflects on his role as a writer when he recounts his own life in the first person or through alter egos.

Before I embark on my analysis, I offer a brief introduction to how the term alienation has been used over the years, with varied and sometimes contradictory meanings. Alienation comes from the Latin alienus, belonging to someone else, to another person, place, or object, alien, foreign, which in turn came from alius, "other" or "another." It can relate both to a personal psychological state and to a type of social relationship. The concept of alienation is closely connected with sociological, economic, psychological, and political contexts. The notion of alienation has multifaceted meanings: from the condition of estranged existence of the soul imprisoned in the body (Plato, Aristotle) to the progressive corruption caused by social evolution from a primitive state of nature (Rousseau); from the dialectical mechanism whereby being is externalized from itself (Hegel) to a religious concept (Feuerbach) or to a materialistic and economic notion (Marx); from the condition of the modern human being in a capitalistic society (Marcuse) to the negation of the world (Heidegger) or to the absurdity of life (Sartre).

Alienation is a theme at the roots of Ottieri's poetics. Throughout his career, Ottieri focused his attention on the theme of alienation from two main perspectives: first, alienation as the condition of workers who become detached from themselves and deprived of awareness in a world dominated by objects; secondly, alienation is presented as a "feeling of unreality," "sentimento di irrealtà" (Ottieri 2004, p. 40), an umbrella term that Ottieri uses to cover a wide range of mental disorders such as depression, schizophrenia, neurosis, and nervous breakdowns. All these disorders share a similar feature: the sensation of being detached from reality.

The first perspective (industrial alienation) is at the core of Ottieri's four industrial works Tempi stretti (1957), Donnarumma all'assalto (1959), I venditori di Milano (1960), and La linea gotica (1962). ${ }^{2}$ At the 
beginning of the 1960s, however, Ottieri feels that he has arrived at a turning point in his life. He decides to quit his job as a recruiter at the Olivetti factory ${ }^{3}$ in order to devote himself entirely to literature. He also decides to abandon his previous narrative themes, which focused mainly on the working conditions inside Italian factories during the reconstruction that followed World War II. As Carlo Salinari highlighted in his article "L'industria divorzia dalla letteratura" (1964), this is a decisive moment for Ottieri (man and writer), who decides that the "marriage" between literature and industry is over. Indeed, in all of his subsequent works, from the publication of L'impagliatore di sedie (1964) to his last novel Una irata sensazione di peggioramento (2002), Ottieri focuses on his mental illness. Through mental alienation, his second take on alienation, Ottieri depicts the daily life of autobiographical characters suffering from psychiatric disorders. These characters, all of whom are projections of Ottieri's alter egos, have low self-esteem and an overall feeling of inadequacy toward the outside world. Ottieri describes these feelings in different forms, focusing on how they significantly interfere with any daily activities. Persistent depressive disorder symptoms can be summarized as a feeling of unreality, and, in its final stages, mental alienation.

It is worth considering that some of these interpretations on the theme of alienation are present in Ottieri's works and were analyzed by Ottieri himself in the first chapters of L'irrealtà quotidiana. In this oeuvre, "un saggio romanzato" (Pampaloni 1966), which has been considered a turning point in Ottieri's career, Ottieri sheds light on what would become the content of his forthcoming works. Through the adventures of his alter ego Vittorio Lucioli, Ottieri tries to explain his own poetics. He is a writer employed in a factory who at the same time attends psychoanalytic sessions to treat his mental disorders. In this work, Ottieri clarifies the nature of his future literary texts: they are intended as a tool to investigate his own mind and to understand his illness in conjunction with the ways in which this illness can influence his writing.

In L'irrealtà quotidiana, Ottieri focuses on both the Hegelian and Marxist analysis of alienation. Ottieri is interested in Hegel's claim that alienation is the inversion of the relationship between the human-social praxis and the institutions created by individuals. Hegel claims that as the subject develops, through its own activity, it creates something that is also its opposite and that becomes an external force, which stands in contrast to the subject itself. A finite mind (the subject) produces things to express itself in objects and, most importantly, to objectify itself in social institutions 
and cultural products. Nonetheless, every objectification is an instance of alienation, and therefore the produced objects become alien to the producer.

The materialistic aspect of alienation comes from Marx's adaptation of the Hegelian dialectic model to the theory of historical materialism, which refers to the process of economic and social alienation in which workers are disconnected from what they produce. Briefly, according to Marx, ${ }^{4}$ workers are alienated because, in industrial production under capitalism, they inevitably lose control of their work and thus, ultimately, of their lives and selves.

In L'irrealtà quotidiana, Ottieri believes that it is necessary, overall, to clarify the meaning of the term alienation in order to understand the different connotations associated with the various forms that this phenomenon takes. Variability is indeed the most significant trait of alienation since it can be observed on economic, sociological, political, and religious levels. Therefore, care must be taken to avoid confusion and misunderstandings. Referring to the German word Entfremdung, "alienation," Ottieri notes that Freud and Marx used the term in different domains "senza contare che l'Entfremdung di Marx è già la derivazione materialistica di un'altra Entfremdung, quella idealistica di Hegel" (Ottieri 2004, p. 52). According to Ottieri, the distinction begins with the German word Entfremdung, literally "being alienated-to-something," a passive forfeiting of the self to an external power that fits perfectly with the man who suffers "the feeling of unreality." Ottieri argues that this interpretation must be distinguished from both Verfremdung, "alienation-from-something" that is an active estrangement, and from Entäusserung, "objectivation." It is also necessary to differentiate it from Verdingung, "reification," in which alienation transforms itself in total loss of the world, leading to psychotic phenomena such as schizophrenia or the feeling of becoming another thing: "Non c'è fretta. È sentirsi buttati fuori dal mondo, girare così svelti che ... esco fuori dalla realtà, ci monto sopra, sulla realtà" (Ottieri 1964, p. 188).

Because of its polysemous essence, according to Ottieri a clear distinction should be made, otherwise a semantic overload of this term could render the word useless: by signifying too much, alienation could, in the end, not mean anything at all. Ottieri argues that when the term appears in different spheres such as philosophy, economy, politics, and psychology, it should not be confused with what he calls alienazione unica. For Ottieri, the "feeling of unreality" helps to build a bridge between psychological 
alienation and sociological alienation. In this way, this "feeling" promotes cooperation between different domains. By avoiding the risk of an alienazione unica, the "feeling of unreality" is rather the attempt to establish a dialogue between Marx and Freud, without reducing one to the other.

Riflettere poco sulla differenza fra alienazione psicologica e alienazione sociologica, e infischiarsi del loro rapporto, ha portato l'alienazionismo in salotto. Al contrario c'è l'obbligo di chiarire alienazione psicologica e psichiatrica rispetto ad alienazione filosofica, politica ed economica, oggi che la malattia mentale è vicina alla cultura e reciprocamente; e che mai l'alienazione più celebre, quella dell'operaio, si è tanto allargata all'universo. [...] Ovvie distinzioni vanno ricordate quando corre troppo l'abitudine di mescolare alienazione filosofica, economica, politica e psicologica in base a certe loro somiglianze e di pasticciare con una Alienazione Unica Confusa. (Ottieri 2004 , pp. 53, 76)

In L'irrealtà quotidiana, Ottieri examines the concept of alienation through his alter ego, the main character Vittorio Lucioli, who suffers from this "feeling of unreality." According to Ottieri, the most important feature of this kind of alienation is that it defines the condition of individuals in industrial and capitalistic societies where they are detached from themselves, deprived of their consciousness, and immersed in a world dominated by objects.

Ottieri was aware of the contemporary debates on this subject, highlighting the fact that individuals living in the neo-capitalistic world appear lifeless, disheartened, devitalized, and neurotic as they are reduced to objects similar to the objects they want to possess. In the sixth chapter of the first part of L'irrealtà quotidiana (significantly entitled L'operaio pazzo), Ottieri identifies three essential topics in his poetics: the joint presence of psychoanalysis (Freud) and materialism (Marx); mental illness; and the alienation suffered by workers inside industrial society. Ottieri pays attention to modern alienation, emphasizing that not only factory workers, but also the wealthy bourgeois, who naively consider themselves independent consumers of goods, suffer from states of alienation:

La scoperta sociologica più inflazionata negli ultimi anni non è stata la diagnosi di alienato al povero uomo che sembrava scegliesse di più, a colui che ingenuamente si credeva un libero, capriccioso consumatore di beni di consumo? È stato l'ultimo pilone per completare il Ponte dell'Alienazione che ora scavalca tutta l'umanità e non si vede su quale disalienazione si appoggi. 
(L'ultimo pilone è subdolo: interessatamente l'hanno infitto i persuasori occulti, spostando il baricentro del neocapitalismo da monte a valle, dalla fabbricazione alla distribuzione, per la maggior gloria del consumismo imperante). (Ottieri 2004, p. 54)

In L'irrealtà quotidiana, Ottieri also argues that the more consumer goods we are surrounded by, the more desperate we will feel and the stronger the harrowing emptiness will be inside us. Eventually, we will learn that in prosperity there is only the non-entity that is the fetishism of profit. Beneath the glittering magnificence of that new world, there are dark emotions such as boredom, repugnance, powerlessness, and unreality that bring humankind towards its lowest stage: absolute nothingness or alienation.

As previously stated, in L'irrealtà the notion of alienation holds an explicitly political and ideological meaning. Many of the same ideas reemerge, albeit within a different framework, in Ottieri's subsequent works, including, for example, in the poem Il palazzo e il pazzo: "La depressione pubblica/e quella privata si intrecciano./Non te lo dice un ideologo,/ma uno scorticato vivo, scarsamente/abbiente" (Ottieri 1993 , p. 33).

Ottieri maintains that, in a psychiatric environment, the term alienation is commonly linked to the adjective "mental." Besides the generic meaning of "madness," in order to clarify certain aspects of alienation Ottieri focuses on two examples of alienation used in psychiatry: obsessive disorder and schizophrenia (Ottieri 2004, p. 50). In obsessive disorder, the subject attempts to repress his or her own emotions and experiences them as extraneous strengths. In schizophrenia, some organs and corporal areas or the whole body are alienated and thus perceived as if they did not belong to the person, or as if they were different from what they really are.

In addition, Ottieri sheds light on the relationship between the "feeling of unreality" suffered by his alter ego and the general phenomenon of alienation, or with particular forms of this. Because this is exquisitely a solipsistic feeling that is extraneous to any collective experience, the "feeling of unreality" - as an alienated condition-denies reality and at the same time rules out any incongruity.

Al primo colpo d'occhio il sentimento d'irrealtà sembra la rete di confine fra alienazione in sede psicologica, che spesso ne è invasa, e alienazione sociologica dove l'infiltrazione del sentimento d'irrealtà sarebbe respinta da una superficie liscia e oggettiva come la pietra. (Ottieri 2004, p. 54) 
Through these reflections, Ottieri comes to define the "feeling of unreality" in a theoretical way. In his view, it is the outcome of psychiatric alienation; that is to say, it amounts to depersonalization read as a psychological process in which the individual does not perceive him/herself as present in daily life and interacting with others. Such depersonalization can be, according to Ottieri, autopsichica, when personal identity is perceived as changed, extraneous, unreal; somatopsichica, which concerns the body; allopsichica, which corresponds to Entfremdung in which the external world appears unreal. Depersonalizzazione allopsichica, characterized by emotional emptiness and apathy, is associated with derealization, the progressive loss of the feeling that reality is real, as it were. The "feeling of unreality" can be interpreted as a daily, continuous annihilation of existence.

Le soste, i ripensamenti, favoriscono l'irrealtà, che però non è semplicemente la solitudine e nemmeno, come hanno sospettato alcuni, l'astrazione dei filosofi, per lo stesso motivo per cui non è la coscienza, bensì è attigua alla coscienza. [...] È un incrocio-ingorgo fra la perdita dell'ovvietà quotidiana concepita come verità e la medesima perdita concepita come catastrofe, da parte di uno il cui amore per il mondo è disfatto. [...] È un intero sussulto agghiacciante dell'esistenza. [...] Come direbbe Sartre, uno spasmo dell'Io. [...] L'irrealtà quotidiana è per l'appunto il contrario dell'ovvietà quotidiana, è la perdita di essa e dell'ovvio calore dell'esserci.' (Ottieri 2004, pp. $25,26,59)$

Ottieri carries all these aspects of alienation into a literary context. At this point, some methodological issues arise in Ottieri's considerations: where is reality in the "feeling of unreality"? Is it possible to concretely represent the abstract phenomenon of alienation related to this feeling? If it is possible, what kind of literature can arise from this peculiar illness that affects all perceptions? How much can Ottieri freely write about his illness if the essential element of his life is the illness in itself?

Ottieri thinks that it is necessary to envision the feeling of unreality as something that is very concrete. The act of writing could enable him to express alienation in a more tangible way. For that reason, in one section of L'irrealtà quotidiana Ottieri analyses three contemporary novels (Moravia's La Noia, Volponi's Memoriale, and Berto's Il male oscuro) where alienation is represented in a narrative way. Ottieri highlights how, through their works, these writers have depicted alienation as both a psychological phenomenon regarding the individual, and as a process typical of the modern age that causes lack of self-recognition and identification. 
In the attempt to describe alienation, Ottieri recognizes that, above all, he should render an abstract feeling concrete. Psychoanalysis and autoanalysis can help Ottieri to achieve this goal, first by analyzing his own anguish and then by describing it in a literary manner.

Il freudismo intende spiegare anche la scelta di se stesso. Analizzerà il mio arrivo alla psicoanalisi nel lontano 1940, tramite un amico. Quale amico? Perché le sue parole mi impressionarono? La psicoanalisi rincorre il suo a priori. (Ottieri 2004, p. 183)

Il lavoro di analisi è un buco che si fa nel profondo, buco che viene continuamente ricoperto da detriti, che sono i sintomi. [...] Ho cominciato presto a leggere Freud e ho avuto i primi contatti con un analista nel '46, appena finita la guerra. Sono stato fra i primi in Italia. (Ottieri 1972, pp. 18, 91)

The principal aim is to plumb the depths of the disease and dive into the dangerous zones of the human mind where even merely hoping for a normal life seems unachievable. His illness (chronic depression that leads to an alienated condition) becomes an instrument that enables Ottieri to analyze himself and reality. Ottieri's works represent a ruthless and, at the same time, grotesque examination of the absurdity of everyday life in a meaningless world. In the mental hospitals where Ottieri spent most of his life to treat his depression, ${ }^{5}$ he uses the act of writing as a tool to better comprehend (and at the same time describe) his mental conditions.

As previously stated, Ottieri's main intention is to describe what cannot be easily represented, such as the abyss of mental illness that forms a central theme in his writing. From this perspective, literature means salvation. In a circular way, Ottieri tries to seek safety in writing about the illness that brought him close to suicide. He often explains that he needs to write about his mental disease (although it is nothingness full of despair) to be alive. In short, his agonizing illness makes the writer unravel, leading him to breakdowns, distress, anxiety, fear, and alienation.

Sommandosi i giorni, arrivai all'idea del suicidio. [...] Avrei voluto suicidarmi, ma sopravvivere al suicidio, e certamente tale contraddizione mi indeboliva. Mi occupai della scelta del mezzo con cui darmi la morte. [...] Ho la mania... la mania di morire... di suicidarmi. [...] Intanto io già pensavo alla logica del suicidio. Consisteva nella sicurezza-finta—che ormai il suicidio non fosse una decisione disperata, ma l'unica soluzione corretta della mia esistenza. [...] Per liberarmi dalla malinconia, dalla depressione, ho pensato 
che ci fosse un mezzo unico... lei, dottore, ha già capito, un mezzo che non è davvero nuovo... anzi, è notissimo... lei saprà... il suicidio. [...] Il suicidio è diventato la mia idea fissa. [...] Provavo nostalgia del suicidio poiché la disperazione che vi porta per la prima volta, veduta da un'isola, è un elemento mosso e attraente, una tempesta luccicante. (Ottieri 1967, pp. 97, $105,142,143,147,157)$

As alienation is a complex condition, involving both sociological and psychological factors, Ottieri goes beyond the generic use of the term, looking for a clear definition that is able to properly describe his own psychological disorders. In his works set in psychiatric hospitals, ${ }^{6}$ Ottieri focuses on the sense of estrangement felt towards the external world. Mental alienation indeed emerges when his autobiographical characters withdraw or become isolated from their environment or from other people. Ottieri's protagonists often show symptoms of alienation by rejecting loved ones or society, and also show feelings of distance and estrangement, including from their own emotions. In a world felt as empty or meaningless, the characters separate themselves from everyone else, and have feelings of hopelessness and isolation alongside a sense of loneliness or exclusion.

La malattia, superata o tamponata è diventata una vita. [...] La depressione è tutto il dolore possibile riunitosi in una pianura unica dove non sorgono alberi. Stasera non mi sento depresso per la clinica ma per la vita. Questo non è un episodio dell'esistenza, ma questa è l'esistenza. (Ottieri 1972, pp. 53, 216)

Svegliandosi nel pomeriggio ebbe di nuovo l'ora agonica. Nella depressione endogena, l'ora agonica al risveglio è naturale. Bisogna lasciarla sciogliere per superare, con dolorosissima incertezza, il crinale dalla parte della morte, e iniziare il declivio dalla parte della vita, movendosi piano piano a passettini con il massimo dell'ansia. (Ottieri 1976, p. 24)

From these perceptions of strangeness and absurdity towards reality, the feeling of alienation can induce an awareness of no longer having relationships with other people or everyday objects. Coercive and irrational tendencies then push Ottieri's autobiographical characters to exhibit many strange behaviors that they fully understand to be useless. However, if they do not accomplish these acts, anguish immediately emerges-showing clearly the obsessive nature of their neuroses. 
The disease suffered by the author in his own body and mind condemns him to an endless crisis in which normal contact with reality is irreparably lost. Therefore, his bewilderment in the face of life involves sensations of alienation and a feeling that the whole world is ending. When depression and his alienated states of mind decrease in intensity, he can eventually write about alienation. To sum up, his salvation (writing about his illness) is fed by the illness itself, which breaks the writer down:

Scrivo unicamente per sopravvivere, scrivo per scrivere, per gettare un ponticello sopra l'abisso, per essere nella realtà e nello stesso tempo per estrarmi dalla realtà. $[\ldots]$ Quello che sto scrivendo non posso fare a meno di scriverlo. Devo fissare questo nulla. Nelle prime tre settimane il nulla era troppo pieno di disperazione. Diminuita la disperazione, prende forza il lavoro. Non ho altro lavoro che scrivere, scrivere anche del non scrivere. (Ottieri 1972, pp. 20,69)

Ottieri represents alienation in a literary way by depicting it as a psychological condition of dissatisfaction, apathy, emptiness, and reluctance to take action. This painful state that is narrated in the texts epitomizes characters' experiences. Other symptoms also become frequent topics of his works, such as the inadequacy of actions, the inappropriateness of choices, and the deficiencies of a reality that is no longer comprehensible. One of the consequences of this state is that the autobiographical characters feel themselves to be alienated from reality. It is almost impossible to live in such an alienated condition, whilst the act of writing reflects a painful state in which writing nourishes itself through the disease.

In order to describe the disease suffered by both his body and mind, Ottieri switches continually between narrative and poetry. ${ }^{7}$ For him, narrative describes too much and too slowly. On the contrary, poetry can provide a more accurate and immediate depiction. Ottieri defines his poetry as a rhythmic prose or a narration in verse, arguing that with verse he can go straight to the heart of the matter:

La poesia è un'irruzione irrazionale, nasce senza che io lo premediti. Sono un narratore, tutti i miei libri di poesie nascono come per miracolo. $\mathrm{O}$ forse nascono da un fenomeno di estenuazione della prosa. (Vergine 1990, p. 117)

Non sopporto più le descrizioni, le lentezze della narrazione in prosa. Coi versi posso andare dritto al centro del problema e poi, altro vantaggio, la poesia è più vicina al procedimento mentale psicanalitico, quello che in 
linguaggio chic si chiama associazione involontaria e che detto terra terra suona: andar di palo in frasca. (Ottieri 2005, p. 181)

His verses reproduce mental distress, such as the disintegration of thoughts that leads to a fragmentation of reality. Technically, he cuts his lines into fragments that are precariously linked through enjambment to reproduce this distress (Ottieri 1986, pp. 10, 11, 14).

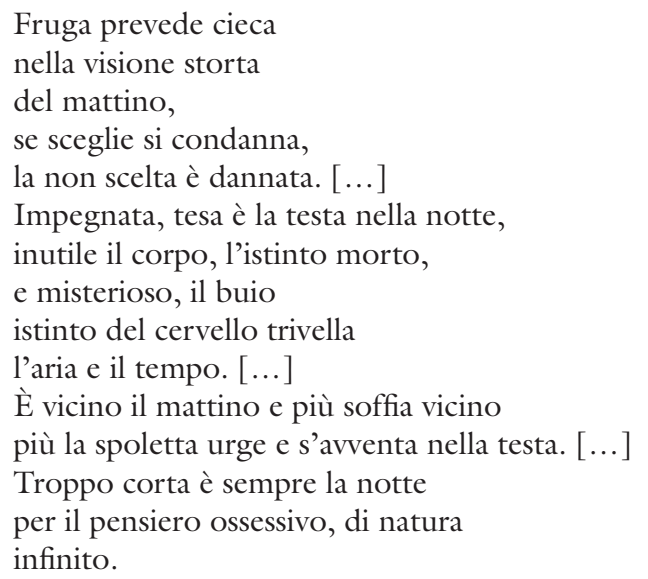

In his first poetry collection, Il pensiero perverso, Ottieri narrates his alienated states as victim of his illness and as witness of his inhuman condition. The author here chooses the third person, giving the narration a more objective point of view. He seems detached from what he is recounting, and at the same time he declares a sort of neutrality about a matter that can be described but not easily expressed (Ottieri 1986, pp. 38, 40). ${ }^{8}$

Dalla sua gelatina ora non filtra che un sentimento perso.

Il pensiero perverso sostituì l'irrealtà:

passò il dereismo attraverso il vuoto

prima di approdare all'odierno perverso,

graticcio che copre il buco del vuoto,

occupazione, spirale. [...]

Non ride né

gli riesce la permanenza devalorizzante:

avida di valore la vita. Aspetta che passi la

colata di piombo

nel cervello. 
Among a large number of manifestations through which alienation can be represented, Ottieri focuses on three recurrent features that are depersonalization, dysmorphophobia, and a distorted perception of time. Ottieri epitomizes mental alienation through depersonalization (or selfestrangement), which is the experience of feeling unreal, detached, estranged from one's self, and unable to feel emotion. Ottieri describes depersonalization as a disorder marked by periods of feeling disconnected from one's own body and thoughts. Sometimes it seems that the writer is observing himself from outside his body. This dissociative disorder involves disruptions of memory, consciousness, identity, and perception. Usually these symptoms interfere significantly with the characters' general ability to function, including social and work activities, and relationships.

Per me vivere o morire è la stessa cosa... Non trovo le parole per esprimermi, per dire se è che non esisto... Per me non c'è più niente e non sono, io, più niente... Sono incosciente, ho perso coscienza... È impossibile descrivere questi stati. È abominevole e nello stesso tempo incomunicabile, ci vorrebbe un linguaggio speciale. Ł̀ qualcosa di ordine cosmico, sarebbe necessario avere un linguaggio che corrisponda a un linguaggio di quest'ordine... Io sono il vuoto, sono l'inferno, non esisto... Sono morto... $\mathrm{Si}$ è tuttavia esseri umani, il mio universo è il vuoto... Ci sono e insieme non ci sono... Non abbiamo che il vuoto... Sono la morte, essere la morte è un modo d'essere immortali. (Ottieri 2004, p. 34)

One of the common symptoms related to depersonalization syndrome is a distorted perception of the body. Ottieri describes a type of somatoform disorder (Body Dysmorphic Disorder, also known as dysmorphophobia, or the fear of having a deformity) through which he has a preoccupation with an imagined defect that causes clinically significant distress or impairment in social, occupational, or other important areas of life. ${ }^{9}$

L'orrore del proprio fisico. L'ossessione della pancia. [...] Mi sono ingrassato e invecchiato, fisicamente mi odio. [...] Odio per il proprio fisico, una irreparabilità tragica, una inimicizia contro se stessi. (Ottieri 1972, p. 15)

When observing his own body, Ottieri is constantly obsessed by it, even if no actual defect can be identified. As a result, because he sees himself as ugly, he and his characters often avoid social exposure because their appearance seems so shameful and distressing. Dysmorphophobia can be a chronic long-term disorder, and it affected Ottieri from his teens to his adult life. 
Time is another significant element that epitomizes states of alienation. Time is represented in relation to two essential features: it does not exist (as it passes too slowly) and it simultaneously oppresses the patient. It is an eternal suffering without past or future. Time in Ottieri's works emerges in an oxymoronic way: the eternal present is a "timeless" time. Nevertheless, it seems to be the most compelling example of the condition lived (or rather not lived) by the writer (Ottieri 1986, pp. 11, 14, 15):

Il passo della realtà, del tempo, non lo tengo, lo scavalco, perché è troppo lento... Oppure vado io più lenta. Il tempo è una cosa strana, estranea... troppo... densa. (Ottieri 1964, p. 188)

Troppo corta è sempre la notte per il pensiero ossessivo, di natura infinito. [...]

Inganno che il dubbio ossessivo si calmi la notte.

Dorme sì qualche volta. [...]

Evita il risveglio, prolunga il sonno come un elastico. [...]

Progredisce nel tempo il pomeriggio

doloroso e noioso come pura

consunzione del tempo. [...]

Il tempo medica il dubbio. Ma il dubbio rinasce dal tempo.

In this context of endless time that only brings on more suffering, Ottieri experiences a sort of living death. He can barely accomplish the elementary steps of a normal daily life such as sleeping, eating, washing, and dressing himself. He is distraught and petrified while his thoughts are close to suicide, which seems to be the only escape from such an ill-fated condition:

Il tempo si rischiara, la grande depressione si solleva lentamente a decimi di millimetro. Si sta attaccati alle più scarne origini, dormire, mangiare, lavarsi, vestirsi. Si sta a un centimetro dal suicidio. [...] Mi sento strano sconvolto irreale. [...] Il mondo mi ruota intorno alla testa. [...] Ho terrore. Tramortito, allucinato, rivoltato come una fodera. Mi rifugio nel letto. [...] Per quanto tempo sarà così? Per mesi? Anni? Ho terrore. (Ottieri 1972, pp. 25, 45) 
Feeling alienated can lead to many different social problems. One of the complications experienced by Ottieri's autobiographical characters is alcohol abuse. Ottieri's characters drink to reduce their symptoms through a self-medicating therapy. The downside of this approach is that, in the long term, alcohol makes these disorders worse as it interferes with the chemical balance in the brain.

Non avevo forse il diritto di profumarmi? Ne bevvi tre grandi sorsate. Mi sentì [sic] subito meglio anche se la colonia non è propriamente gentile al palato, alla gola. Raschia. [...] Niente di strano. Un depresso ha crisi depressive, si dà all'alcol, sfiora il suicidio o si suicida. [...] Non sono matto perché sono alcolizzato. Curo la follia con l'alcol. È a nasconderlo che mi vergogno. (Ottieri 1999, pp. 21, 98, 117)

Drinking plays an essential part in the daily lives of Ottieri's characters. They find it almost impossible to enjoy themselves or relax without having a drink, as they have become addicted to alcohol: "Si pensa che mi interessi tanto/di suicidio e rivoluzione/non per via di attualismo/ma di birra" (Ottieri 1993, p. 36). Ottieri also draws particular attention to symptoms related to addiction such as sweating, shaking, and nausea. When addiction sets in, alcohol takes over the central role in someone's life, and Ottieri's characters usually end up giving up important activities and relationships because of their drinking. Among the warning signs and symptoms experienced are waking up and drinking or feeling the need to have a drink in the early hours of the morning (Ottieri 1993, pp. 41, 60):

\footnotetext{
La mattina presto l'alcole ha doppia euforia e onnipotenza, presto diventa un massacro.

Ne chiedo un'altra. [...]

Mi svegliai prestissimo, corsi

al baretto delle corriere.

Alle 7 bevvi tre birre.
}

Because it is impossible to overcome his alienated states either through psychotherapy or the abuse of alcohol, Ottieri eventually decides to accept his condition and therefore to experience it with irony and sarcasm. He uses literature to portray a specific character in a life-long performance, playing the part of the suffering protagonist (the writer himself) that is always defeated and never on the way to recovery. His only salvation is 
going from one clinic to the other; a process that it is called "clinichismo" by Ottieri, that is the long period of his life spent in therapy and in hospitals without any recovery:

Io sono legato al primato della sofferenza. Io batto tutti. [...] Io conosco tutte le cliniche d'Europa, sono stato ricoverato ovunque, potrei scrivere una guida come quella dell'Espresso per i ristoranti. (Zoli and Cassano 2006, pp. 424-430)

Although his works about mental illness recount a miserable life of suffering, an underlying irony emerges from the pages. Sometimes his works seem like a grotesque-picaresque report of a "hero" who fights against the disease. As Ottieri is not able to defeat or even alleviate it, he is sarcastic about himself and the illness, depicting his terrible condition with a great amount of irony. This is one of the most significant features of his works: irony as self-defense against illness. Very often, the rooms or wards of his hospitalizations become a stage where he can play the role of a "clever" patient (Ottieri 1991, pp. 28, 54, 66):

Scrivere è blobbare, acchiappare tutto con ironia, l'altra faccia della malinconia. (Ottieri 2005, p. 188)

Forse egli era uno degli inventori della ironia, ma era anche così autoriflesso che se ne rideva della ironia stessa. Faceva, coattamente, ironia della ironia. (Ottieri 2002, p. 100)

'Lei è un istrione' sorride Perugi

'assai bellino. Ha recitato

per tant'anni l'Amleto, ora tocca a Re Lear.

Vorrebbe che noi fossimo

spettatori plaudenti.

Siamo medici che curano.' $[\ldots]$

Facevamo intellettuale teatro. [...]

Per i chirurghi il vecchio

recitava una parte.

Lo chiamavano l'habitué.

In conclusion, in his works and through the guise of many autobiographical characters, Ottieri analyzes his own life, eager to understand the causes of neurosis, depression, and mental illness that characterize his perception of the world. Through psychoanalysis, Ottieri needs in fact to redeem 
himself from his own anguish. To accomplish this, he is driven to analyze the (personal and collective) illness of his own time: alienation, investigated through its materialistic and psychological aspects. Therefore, this analysis, balanced between the individual and the collective, becomes gradually an inquiry into the world-weariness that the whole of humankind has in common. In an attempt to heal himself from this alienated condition, Ottieri starts a conflicting relationship with the therapies and the doctors that treat him.

The writer wants to achieve autonomy for the benefit of his work, but freedom of expression is curbed by misleading medical diagnoses. $\mathrm{He}$ must admit, however, that the various treatments he undergoes are at the same time healing processes and instruments of torture; they both allow him to develop intellectually and also increase his agony.

\section{Notes}

1. "Non sono un malato ma un policlinico... Un congresso medico da solo. [...] Modestamente la mia vita è stata un calvario. [...] Quanto all'esperienza del male, io ho sempre avuto una sintomatologia molto violenta: non è che io fossi solo depresso, ma depresso agitato. [...] Poi non mi sono limitato alla depressione, io. Conosco gli attacchi di panico, il DOC. [...] Avuto anche quello. Alla fine, dopo essere arrivato completamente astemio fino ai quaranta, pure l'alcolismo" (Zoli and Cassano 2006, pp. 424-430).

2. Interest in the industrial world began to develop in Ottieri at the end of the 1940s, when he read Marx's and Weil's works. The years that follow the end of World War II, labeled as the "Italian economic miracle," are known to be a crucial turning point for Italy as it changed from a mostly rural and traditional country to a modern, rich, consumer society. Ottieri realized that, in order to better understand the working-class condition in this period of sustained economic development, it was necessary to be employed in a factory. Only in this way did he think he could see with his own eyes the relationship between workers and both the machines and employers. That is why he moved from Rome to Milan in 1947. He thought that it was easier to find a job in a factory in Milan, the economic capital, rather than in Rome, where he could only find a job as a journalist or a translator in a publishing house. In the works mentioned above, Ottieri describes the dark side of the "Economic Boom" and the estrangement from a society that was changing in a negative way.

3. Ottieri worked as selezionatore del personale at the Olivetti factories in Ivrea, Pozzuoli, and then Milan from 1953 to 1964. "L'altro mio padre che mi ha salvato la vita/e l'arte,/è stato l'ingegnere Adriano Olivetti. [...] Egli non 
era un mecenate, $/ \mathrm{ma}$ un intellettuale, come quelli che amava e molto pagava" (Ottieri 1993, p. 68).

4. See Marx (1994).

5. To mention but a few: Klinik am Zürichberg (Zurich), Casa di cura San Rossore (Pisa), Casa di Cura Le Betulle (Como), and Hôpital de Cery (Lausanne).

6. See in particular Il campo di concentrazione (1972), Contessa (1976), L'infermiera di Pisa (1991), Il diario del seduttore passivo (1995), Cery (1999), Una irata sensazione di peggioramento (2002).

7. Along with his novels, starting from Il pensiero perverso (1971) Ottieri published several other works of poetry: La corda corta (1978), L'estinzione dello stato (1982), Versi adolescenziali (1986), Vi amo (1988), Il padre (1990), L'infermiera di Pisa (1991), La questione meridionale (1992), Storia del PSI (1992), Il palazzo e il pazzo (1993), Le guardie del corpo (1994), Il diario del seduttore passivo (1995).

8. As Pasolini highlighted: "Ottieri ha fatto oggetto della propria poesia qualcosa che per definizione può essere forse descritto, ma certo non espresso. [...] La poesia, a meno a dedurlo dal libro di Ottieri, può esprimere meglio della scienza, da una parte, e naturalmente peggio, dall'altra, gli stessi fatti, lasciandoli alla loro sostanziale inesprimibilità" (Pasolini 1999, p. 2568).

9. See Di Maio (2011, pp. 389-398).

\section{REFERENCES}

Di Maio, Fabrizio. 2011. Ottiero Ottieri e la dismorfofobia letteraria. In Attorno a questo mio corpo: Ritratti e autoritratti degli scrittori della letteratura italiana, ed. Fabio Pierangeli, Laura Pacelli, and Maria Francesca Papi, 389-398. Rome: Edizioni Hacca.

- 2014. Ottiero Ottieri: Un caso letterario. Rome: Carocci.

Gaccione, Angelo. 2000. Intervista ad Ottiero Ottieri. Milano metropoli 3: 21.

Marx, Karl. 1994. In Selected Writings, ed. Lawrence H. Simon. Indianapolis: Hackett Publishing Company.

Milano, Paolo. 1962. L'autobiografia e la cronaca. L'Espresso, December 21.

Ottieri, Ottiero. 1964. L'impagliatore di sedie. Milan: Bompiani.

—_. (1954) 1967. Memorie dell'incoscienza. Milan: Bompiani.

- 1972. Il campo di concentrazione. Milan: Bompiani.

- 1976. Contessa. Milan: Bompiani.

_. (1971) 1986. Il pensiero perverso. In Ottieri, Ottiero. Tutte le poesie. Venice: Marsilio.

- 1991. L'infermiera di Pisa. Milan: Garzanti.

- 1993. Il palazzo e il pazzo. Milan: Garzanti.

- 1999. Cery. Parma: Guanda. 
- 2002. Una irata sensazione di peggioramento. Parma: Guanda.

-. (1964) 2004. L'irrealtà quotidiana. Parma: Guanda.

- 2005. Cronache dell'al di qua. Cava de' Tirreni: Avagliano.

Pampaloni, Geno. 1966. L'irrealtà quotidiana. Il Resto del Carlino, July 9.

Pasolini, Pier Paolo. 1999. Satura, Il pensiero perverso, La beltà. In Pasolini, Pier Paolo. Saggi sulla letteratura e sull'arte, 2568. Milan: Mondadori.

Pedriali, Giuseppe. 1995. Cantare il male dell'anima. Il Libro della settimanaItalia Oggi, April 8.

Salinari, Carlo. 1964. L'industria divorzia dalla letteratura. Vie Nuove, August 6.

Vergine, Lea. 1990. Gli ultimi eccentrici. Milan: Rizzoli.

Zoli, Serena, and Giovan Battista Cassano. 2006. E liberaci dal male oscuro: Che cos'è la depressione e come se ne esce. Milan: Longanesi. 


\title{
CHAPTER 6
}

\section{Paolo Volponi's Memoriale: Industry Between Alienation and Utopia}

\author{
Tiziano Toracca
}

Ed anche a tanti anni di distanza, dopo tanti anni durante $i$ quali vi ho lavorato, non so dire se la fabbrica sia bella o brutta [...]. Oggi posso dire che la fabbrica è sempre stata in un ordine perfetto [...] sempre pulita e sempre sconosciuta. Questo vuol forse dire che la fabbrica è bella; ma io non posso dire che la fabbrica sia bella [...]. Nel corso di tanti anni, qualche volta mi è sembrata bellissima; ma ero io a giudicarla dentro di me quasi senza vederla.

P. Volponi, Memoriale, pp. 14-15

\subsection{INTRODUCTION}

Memoriale was published by Garzanti in March 1962 and was immediately considered one of the most relevant works of industrial literature (Volponi 1964; 2002, pp. 1089-1104). In Italy, in the years when Memoriale was conceived, there was an increasing debate as to how literature should represent the paradigm of industrial labor in order to shape the "trasformazione

T. Toracca $(\bowtie)$

Ghent University, Ghent, Belgium

Università degli Studi di Torino, Turin, Italy

e-mail: tiziano.toracca@ugent.be; tiziano.toracca@unito.it

(C) The Author(s) 2019

A. Diazzi, A. S. Tarabochia (eds.), The Years of Alienation in Italy, https://doi.org/10.1007/978-3-030-15150-8_6 
grandiosa e terribile" that occurred during that period (Vittorini 2008). ${ }^{1}$ The debate on literature and industry runs parallel to the economic growth of the country and therefore to the rapid and traumatic process of modernization from which the postmodern era originates (Ceserani 1997; Donnarumma 2014; Toracca 2017). Within this framework, Memoriale represents the "failed meeting between the long, sublime, provincial, chaotic Italian past and modern industrial rationality" (Berardinelli 1997, p. 18; my translation). ${ }^{2}$

In this chapter I am going to challenge the idea that Memoriale represents and criticizes the alienation caused by industrial work. In particular I want to challenge the idea that Memoriale represents the alienation caused by a model of industry that appears "humane" (because it offers rights, services, and assistance to its workers) whilst also being, in fact, dehumanizing (Fioretti 2017).

Volponi chose to tell the story from the point of view of a paranoid worker because only this estranged perspective could reveal the dystopian essence of a seemingly utopian factory $[\ldots]$ where workers could rely on free medical assistance [...]. Only a 'madman' like Albino can see beyond the appearance, showing how this 'humane' industry dehumanizes the worker. (Fioretti 2017, pp. 162-163)

To all intents and purposes, the most important relation that Albino has with the factory is with the health care system that the factory sets up in order to reintegrate him. When he is not on the train or on the bus for his regular journey between his house and his workplace (Scrivano 2000; Bagorda 2015), Albino spends most of his time in the infirmary or in the personnel office of the factory, or at home, sick, resting, or convalescing, with his mother, surrounded by doctors, priests, police officers, magicians. He even writes most of his memoire during his years in a sanatorium, which is paid for by the employer. He spends most of his time in health care. Even sleeping, walking, and watching the snow fall become therapeutic ingredients of his life. The most important relation between Albino and the factory appears to be therefore a sort of therapeutic relation.

If we consider the factory as a disciplinary system in Foucault's terms, Albino appears as an "unclassifiable subject," a "residual," "irreducible" subject who must but cannot be assimilated.

In short, disciplinary power has this double property of being 'anonymizing,' that is to say, always discarding certain individuals, bringing anomie, 
the irreducible, to light, and of always being normalizing, that is to say, inventing ever new recovery systems, always reestablishing the rule. What characterizes disciplinary systems is the never-ending work of the norm in the anomic. I think all this can be summarized by saying that the major effect of disciplinary power is what could be called the reorganization in depth of the relations between somatic singularity, the subject, and the individual. (Foucault 2008, p. 54; see also Illich 1976)

We could summarize Memoriale as the story of the failed attempt made by the factory to cure Albino in order to integrate and assimilate him into the disciplinary order of the industrial organization.

By taking care of Albino, the factory (similarly to other collectivistic institutions such as the asylum or the barracks) attempts to transform him into a "docile body," and the failure of this attempt of "subjectification" brings about Albino's loneliness and his exclusion (Foucault 1995; Basaglia 1981). ${ }^{3}$ Albino's dismissal at the end of the book-when he decides to participate in the strike-is the consequence of his "attentato al sistema" (Ferretti 1966, p. 236): it reveals that the factory was ready to help him as long as he proved to be willing to be integrated in the system. Insurgency is not tolerated and is punished.

The interpretation summarized above seems correct to me (Fioretti 2013 , pp. 121-134). However, in Albino's memoire the factory is not only depicted as a form of disciplinary power; its representation is more ambivalent than this.

Albino is a paranoid subject, the only protagonist of the story and its only (homodiegetic) narrator. Because of these formal aspects of the novel, and in particular because of Albino's mania of persecution, we can interpret him as an unreliable narrator. Albino represents the alienation of the industrial system and the inhumane face of the disciplinary power of the factory through his peculiar, hypersubjective, point of view. We are presented with a sort of transference: the insanity of Albino is transferred onto the factory. The insanity of the character draws attention towards the insanity of the system. "Volponi si serve della 'particella stramba' rappresentata dal protagonista per mettere in evidenza l'essenza patologica dell'industria neocapitalistica" (Fioretti 2013, p. 132). It is a recurrent strategy in Volponi's novels: mental illness is adopted as a specific cognitive instrument, as a special lens to get a better understanding of the world. We could say that in Volponi's narrative mental illness has a function analogous to that of the modernist epiphany: it allows us to transcend reality 
and to reveal new, different, meanings (Debenedetti 1971). We have to go beyond the meaning of Albino's discourse to grasp the alienated experience embodied in such a discourse (Foucault 2006, pp. 541-549).

It is by considering the "different" point of view of Albino that we see something more ambivalent than the disciplinary power of the factory. ${ }^{4}$ If we trust Albino we do not only see a real persecution, where there is actually a delusion of persecution, but we also see a utopian will of regeneration, where there is actually a spasmodic and unreasonable need to understand the factory and the work.

Albino Saluggia asks the factory to save him, to give him a brand-new form of life capable of prevailing over his previous diseases. Albino's wish to restart his life by working in the factory encourages us to reconsider the factory for what it abstractly could be and not only for what it turns out to be at the end of the story. Albino's imagination - even his naivety-provides us with a utopian way of thinking about the potentiality that the industrial system has to renovate the human condition.

From the estranged and distorting perspective of the character, the offers of help made by the factory appear definitively negative and oppressive. Nevertheless, Albino's paranoid rejection of the help coming from the factory also reveals a profound cry for help. Albino refuses the assistance coming from all the components of the factory (from workers, doctors, and the president alike) because he perceives that these offers are part of an impenetrable and hostile system wherein he is a sort of prisoner. At the same time, however, he continues to request the factory to help him and in particular, even when he is ill, he demands to work in order to be finally considered healthy. The offers of help and assistance made by the factory to Albino correspond with a request for help made by Albino to the factory and this mutual relation is very ambivalent. Albino's estranged and paranoid perception reveals simultaneously a fear of being defeated and a desire to be saved. Albino's suffering is independent in many respects: it does not start and it does not end in the factory when the factory tries to help him. The industrial capitalist system destroys Albino as a human being, but as a human being Albino expects the system to be different, healthy, and wholesome.

In the antinaturalistic, estranged, neo-modernist form of the novel (Toracca 2018) a utopian image of the factory also hides. Along with the radical criticism against the industrial machinery (and this is certainly one of the most powerful leitmotifs of the novel; see Ferretti 1966, pp. 228-241; Volponi 1995, pp. 79-87), Albino's interior, delirious voice 
brings out "the dream of an orderly industry" (Volponi and Leonetti 1994, p. 29, my translation). In Albino's memoire there is not only the complaint about the alienation generated by the industrial system: his final total rejection of the factory (which also means the rejection of the traditional, progressive, instruments to fight labor exploitation in order to achieve social welfare) betrays an opposite desire, a desire of regeneration. The factory model represented in Memoriale is rejected by Albino not only because it creates alienation but also because it creates alienation while it should lead to safety. The factory is, at the beginning of Albino's experience and in general in his imaginary, a possibility. Albino asks of industry something different from what the other workers ask, from what Pinna, Grosset, Gualatrone-or the strikers in the conclusion of the novel-aim to obtain. He asks for salvation and regeneration. This metaphysical request makes us figure a different, utopian, way to operate the factory.

\subsection{Volponi, Olivetti, and the Dream OF AN ORDERLY INDUSTRY}

We cannot interpret Memoriale just by using the author's biography, but we also cannot overlook the strong and persistent link between Volponi's understanding of the political role of industry and his poetics. When Volponi wrote Memoriale he was directing the social services division at Ivrea (he had been in this role since October 1956 and had been hired by Olivetti in 1950). Some years later, in 1966, he would become head of human resources in this factory (Pistilli 2014). Volponi's industrial culture-a progressive, illuminated, and democratic culture-takes shape through his experience at Olivetti thanks to Olivetti's magistero. The attention devoted to the anthropology of labor-the figure of the worker, the social services related to the working place and the working activities, the relationship between labor and health, beauty, territory, productiondefine Olivetti's as an extraordinary experience (Pampaloni 1980; Gallino 2001; Sapelli and Cadeddu 2007; Ochetto 2009; Bricco 2009; Ferrarotti 2013; Volponi 2003, pp. 645-648). Volponi owes his progressive industrial culture to "il substrato utopico olivettiano, agganciato alla dimensione umanitaria del lavoro e della fabbrica, al suo umanesimo industriale, alla capacità di sintesi fra spirito e materia" (Masi 2016, pp. 87-88; Semplici 2001; Best 2015). Volponi believes in industry and in the political, democratic management of industrial power. The last novel published by Volponi, Le mosche del capitale (1989), is a fierce and grotesque attack 
on the subjects (represented by the flies) who "suck" and "dishonor" industry by treating it as a mere instrument of profit (Toracca 2015), and it is not by chance that Volponi dedicated Le mosche to Olivetti-who is considered a "maestro dell'industria mondiale" (master of world industry).

Even if at the beginning of Memoriale we read that the industrial city of the novel has no identity because the author wants to refer to the industrial system as a whole ("I personaggi e i fatti di questo romanzo sono immaginari; i luoghi e i paesi esistono. La 'città industriale' non ha identità, anche perché l'autore non vuole che, con la pretesa di riconoscere una città $o$ una fabbrica, si giunga ad attribuire soltanto a questa le cose narrate," Volponi 2002, p. 4), it is clear (Wells 1997) that there is a strong link with his personal experience at Olivetti.

The years between the mid-1950s and the beginning of the 1960s were nevertheless also years of alienation at Olivetti. The production of the new electro-mechanical calculators (the well-known C24) in fact "accentuated dramatically the division between neuropsychic irrationality and business rationality" (Zinato 2002, p. 1074; Friedmann and Sheppard 1955; Friedmann 1992). Volponi observes these processes very closely. In particular, he sees the efforts taken and the strategies employed by the factory to prevent the pathologies caused by the new productive rationalization. In their collective work that focuses on the psychology of labor at Olivetti, Musatti, Baussano, Novara, and Rozzi write:

La razionalizzazione e parcellizzazione del lavoro andava comportando rischi di precoce deterioramento psicofisico anche per i nuovi assunti. Il criterio per destinarli ai lavori più razionalizzati come le linee di montaggio non poteva consistere tanto in una specifica idoneità attitudinale $[\ldots]$ quanto nella capacità di sopportare lo stress prolungato di detti lavori [...].Questi fenomeni non solo hanno determinato il lavoro degli psicologi, ma hanno costituito problemi per i capi diretti e per i servizi del personale, e hanno inoltre vivamente influenzato l'atmosfera culturale dell'azienda: il Memoriale scritto da Paolo Volponi in quegli anni, ne è testimone. (Musatti et al. 1980)

The fabula of the novel lies in a letter that a worker suffering from tuberculosis sent to Adriano Olivetti (Volponi, 1977), and like Olivetti the industry of Memoriale tries to take care of Albino (Vazzoler 2004-2005).

The strength of Volponi's writing originates in the coexistence and the fusion between social analysis and poetic, expressionist, perceivable visions 
(Santato 1986, 1998). According to Volponi, the factory constitutes, at least in theory, the most effective instrument to achieve freedom and democracy and could be a source of public wealth: this belief is explicit in many pronouncements by the author (Volponi 1967; Ferretti 1972, pp. 1-7; Volponi 1973, pp. 123-143; 1974a; Marongiu 2003) and it nourishes the peculiar dialectic between apocalypse and utopia that characterizes most of his literary works (Forti 1989). It is very constructive to compare what Albino Saluggia says about industry in some of the most significant pages of Memoriale with what Volponi declared in 1962 on the same issue. Saluggia:

L'importante è che le fabbriche, così come sono fatte oggi, annullano piano piano per tutti quelli che vi sono il sentimento di essere su questa terra $[\ldots]$. Addirittura ci si può spingere a pensare $[\ldots]$ che gli uomini possono arrivare ad essere diversi persino nelle loro storie e nei loro sentimenti [...]. Posso io dire, a questo punto $[\ldots]$ che il problema è quello dell'industria in generale, tutta, dalle sue città e quartieri ai treni e ai pullman che la servono $[\ldots]$. Tutta l'industria, cioè, deve essere controllata, o invece di essere un mezzo per stare bene su questa terra, potrà essere il fine di starci male o il mezzo di uscirne. (Volponi 2002, p. 133)

Paolo Volponi:

Io sono convinto che il progresso tecnico e tutte le sue applicazioni volgari, come gli elettrodomestici, le automobili, la televisione, le autostrade, i supermarkets, aggiungerei le medicine, le case, gli abiti, i giornali, sono cose tutte utili all'uomo e alla sua vita. Sono convinto che non sono colpe del progresso, e di questi suoi buoni frutti, la standardizzazione del gusto, il conformismo, l'alienazione della civiltà di massa [...]. Il problema quindi va visto, come sempre, dalla parte dell'uomo: o l'uomo controlla il progresso tecnico, l'industrializzazione $\mathrm{e}$ la scienza $[\ldots]$ oppure egli dovrà pagare tutto lo scotto che il progresso tecnico, l'industrializzazione e la scienza richiederanno $[\ldots]$ per procedere $[\ldots]$ a conquistare la faccia della terra secondo quella auto-generazione che è tipica del monopolio industriale. (Volponi 1962 , p. 46)

In a thought-provoking interview with Giancarlo Ferretti some years later, in 1966, Volponi declares:

L'industria non va vista come strumento di alienazione, come catena di prodotti, 'società dei consumi,' eccetera, ma come forza liberatrice dal bisogno, dalla fatica, dalle malattie. (Volponi 1966, p. 8) 


\subsection{Beyond Industrial Alienation}

There are two aspects of the text that demonstrate Memoriale is not a novel dedicated only to industrial alienation: there are passages concerning Albino's pain and there are passages concerning his relationship with the factory.

As far as the former is concerned, I would distinguish three main features. First, Albino's discomfort concerns each of his relationships. No-one is a real friend of Albino's (even his mother constitutes an ambiguous, hostile, and horrible presence), either in the factory or outside it, and all objects are or could become negative epiphanies. Albino is not only afraid of women (I refer in particular to the French cousin, and to Giuliana, Marina, Vera, and Eufemia), but he is afraid of everyone. He is really a kind of "leper" (Tchehoff 2015; Chirumbolo 2009, pp. 49-58). Pinna, Grosset, and Gualtrone, the people he associates with most often, remain deeply distant: Albino does not stop feeling suspicious and he maintains prejudices against them. The scene of the "killer pike" in Lake Candia expresses very well the negative and threatening power of the world surrounding Albino, who in all circumstances experiences pain, distress, fear, and suffering (Gigliozzi 1996; Fabrizi 1998). Outside the factory the world is neither warm, nor welcoming, nor inviting, and all of Albino's experiences demonstrate its ontological negativity. "Io sono una goccia/la prima o l'ultima di un acquazzone/caduta dalla grondaia/quando nell'aria/non s'aspettava pioggia,/nemmeno quella goccia." In the final part of the book Albino writes some poems that testify to his discomfort and his loneliness (Santato 1998; Masi 2015).

Secondly, we have no reason to suspect that Albino's pain is already present before he enters the factory. The narrative construction of Memoriale is quite schematic: each of the nine chapters (with the exception of the eighth) contains the story of an entire year, and this structure is a sort of guarantee that Albino is trying to reconstruct and to tell the truth (one of the models of Memoriale is certainly La coscienza di Zeno by Svevo: Guidotti 1998; Spignoli 2012). The war, captivity in Germany, the death of his father, the problematic relation with his mother, the college board, tuberculosis, the paranoid and obsessive tendencies, the superstition and loneliness - all precede Albino's arrival at the factory. At the beginning of the novel, when Albino tells his mother about his pain, she suggests that he pray, go to the doctor, sleep after eating, and finally find 
a job. His mother suggests all those things to protect him. Moreover, her suggestion to find a job could help overcome a previous painful situation.

Thirdly, Albino writes his memoirs at the end of his sad story; that is, when he is aware that nobody can help him. But during his story (which lasts ten years) Albino's behavior changes: he wants to alleviate his pain and the factory represents his last chance; it is the hypostasis of his desire of integration in the society. The night before the first day at the factory, Albino brings his bed to the barn and he spends the night there. He starts to reconstruct the origin and the sequence of his pain and finally he claims: "Io sto per diventare un altro e quindi dovete abbandonarmi [...] Quindi dovete lasciarmi, ritirarvi da qualche parte e magari aspettare di giudicare la mia seconda vita $[\ldots]$. Io saprò scrollarvi dal mio corpo e già domani starò bene, sarò pronto al lavoro" (Volponi 2002, p. 27).

Albino's idea to start a new life is almost a refrain. During their last medical examination of Albino, Tortora and Bompiero are assisted by the chief of medicine of Turin, Dr. Pietra, and by the director of a sanatorium in Saronno, Dr. Ghirardi. This examination might establish the condition of Albino's health "una volta per tutte" (p. 210). It is very significant that the expression "una volta per tutte" (once and for all) is the only expression that appears in italics in the novel. It also appears twice. "Una volta per tutte" Albino is declared tubercular and in need of care. He will leave the factory and he will spend two years in a sanatorium. Albino's "defeat" corresponds here to the impossibility of overcoming his pain by working in the factory. The sanatorium is a space of alienation, but at the same time Albino imagines that only through labor could he change his condition ("Avevo voglia di tornare presto in fabbrica, di riprendere il lavoro e finalmente incontrare la prova delle mie forze," p. 65).

The most important relationship between Albino and the factory concerns health care. As noted by many literary scholars, and most recently in particular by Fioretti (2013), Albino is not a typical worker. Even if it is true that industry irrupts traumatically in the countryside and its rituals, Albino is not a farmer. "Se avessi fatto il contadino e fossi rimasto a Candia, pensavo, non mi sarei ammalato" (Volponi 2002, p. 165). "Tornato a casa dissi a mia madre che sarebbe stato meglio se avessi fatto il contadino" (p. 167). There are many passages in the novel in which Albino describes his alienation at work, but there are also many passages in which Albino considers the factory as an instrument of regeneration and as a source of wealth. In particular, and this is one of the most relevant leitmotifs of the novel, labor is depicted as the best way to fight the illness. The extraordinary 
description of the factory made by Albino only after a few days of work should not be underestimated. His enthusiasm leads him to imagine industry as a place where workers feel safe and protected:

I primi giorni di lavoro non furono brutti giorni; anzi molte cose mi piacevano e mi confortavano: così la mensa, gli spogliatoi, le docce, i grandi corridoi, le luci al neon dentro e fuori, il veder passare alti e silenziosi tanti ingegneri e dirigenti che mi facevano sentire al sicuro, in una fabbrica ben governata. Pensavo con piacere $[\ldots]$ di far parte di un'industria così forte e bella e che la sua forza e la sua bellezza fossero in parte mie e pronte ad aiutarmi, così come la fabbrica mi scaldava e mi dava luce. Amavo a poco a poco la fabbrica $[\ldots]$. Mi sembrava che tutti gli operai avessero poco a che fare con la fabbrica $[\ldots]$ che non si rendessero conto della sua sovrumana bellezza e che proprio per questo, lavorando con più fracasso del necessario, parlando e ridendo, la offendessero deliberatamente. La fabbrica mi appariva sempre più bella e mi sembrava che si rivolgesse a me, come se fossi l'unico o uno dei pochi in grado e ben disposto a capirla. (p. 48)

The description of the factory here-empty, immaculate, great, well ruled-deals with the unexpressed makings of a utopia. The workers-the people who suffer the alienation caused by the factory-are the ones who do not understand its utopian potential. They violate such a project. The empty space of the factory (with all its perfect services and its organization) is opposed by Albino to alienation. The factory annihilates but at the same time, as an empty space, it represents and creates a range of possibilities.

When Albino becomes aware that his work is not useful to himself, he also understands that the factory is more interesting and fascinating when it is empty, which is a symptom of the crucial role of the human management of the factory. The factory is "bella $[\ldots]$ con i suoi vetri e metalli, con le grandi arcate azzurre e tutte le macchine in fila [...] deserta," when "sembra che tutti gli uomini che lavorano a quei posti puliti, vicino ai banchi e alle manopole, debbano essere sinceri e coraggiosi" (p. 50). When Albino starts to hate and to refuse his job because he sees the terrible effects of repetition- "La fabbrica non dava distrazioni a tale pensiero: un albero, un uccello, una parola, un passante" (p. 124) -he says that only at the end of the working hours could he see real human beings: "Soltanto dopo l'uscita sembrava di vedere nella fabbrica finalmente degli uomini" (p. 124). As Albino highlights, the factory does not allow for any lack of concentration during the working hours because it is an introverted, 
exclusive, system. But he does not reject work at all. When he contrasts the repetitive work in the factory with the process of socialization that also happens there, Albino is fostering a utopian imagination.

\subsection{Inside Albino Saluggia’s Memoriale}

Since its publication, Memoriale has been analyzed in two major ways: on the one hand as a romanzo di fabbrica by focusing mainly on its content (in December 1962, for example, the journal of the Communist Party founded in 1944 by Togliatti, Rinascita, dedicated an article to Memoriale in which Volponi was called upon to answer the questions of industry workers and employees (No author 1962; Camon 1969; Spingola 1997) or, on the other hand, as a romanzo livico, by focusing mainly on its form (Pasolini 1999; Calvino 1995, pp. 1765-1769; Giudici 1962; Bonsi 2015). In my opinion, industry and lyricism conflate because Memoriale questions the factory through the mimesis of the inner world of its character.

As noted by some theorists of the "Neoavanguardia" such as Barilli (1962) and Guglielmi (1968, pp. 105-111), the uniqueness of Memoriale comes from its style. The novel depicts the factory by adopting a very distinctive perspective in which the ego and its voice are crucial (Dal Bon 1998). The public sphere is narrated from a private perspective. But if this perspective allows Albino to take control of the facts and to handle his memories (Baldacci 1962) - the most important model for Volponi here is Rousseau (Volponi 1984) — what really counts is the mimesis of Albino's interior world through Volponi's expressionist and poetic language. The lyricism of Albino's voice originates from the combination of two stylistic registers (Pasolini 1999): one of a sick and simple man (Albino), the other of a refined poet (Volponi). As Pasolini (1999, p. 2370) wrote, "l'alienazione di cui si parla è [...] l'alienazione di un alienato. Perciò tutto si moltiplica e [...] si evidenzia." But the stylistic inspiration of Memoriale does not only go in the direction suggested by Pasolini. If Albino's obsessive voice is a special and powerful key to representing the sociological problems concerning the dimension of the factory, it is also, however, a powerful key to suggesting the liberating energy of industry. The intensity of the anti-naturalistic perspective used by Volponi also deals with the ambivalence of the ideology of his character. Thanks to the two stylistic registers he uses, Albino could be in favor of and against industry, and the factory could be depicted as a kind of potential and magnificent essence, threatening but also hopeful. The memoir is impressive because Albino is 
(and wishes to be) adopted by the factory, and at the same time he is (and fears to be) rejected by it. For that reason, he wants and at the same time he does not want the help and the care of the factory. The double, "schizophrenic," movement of Albino's thought (Mastropasqua 1995) leads Volponi to represent the ambivalence of the industrial paradigm (social integration versus social disintegration), that is "la natura dialettica del lavoro umano" (Zinato 2015, p. 72).

L'animazione destruente del reale, di matrice psicotica, del protagonista, l'operaio-contadino folle e visionario Albino Saluggia, rinvia sempre al suo contrario, alla possibilità utopica di redenzione, di conciliazione dell'uomo con gli oggetti, grazie al lavoro liberato [...] la scrittura con cui Volponi racconta la modernizzazione italiana è poetico-romanzesca, data dall'immissione di fitte colate di poesia entro l'universo narrativo. In Volponi, l'attività lavorativa - grazie a questa trasfigurazione poetica—è colta nella sua duplicità dialettica. (p. 74)

Albino is searching for something more than a job: he is searching for a new healthy vision of the world. The utopian horizon of industry deals with the challenging request that a very special subject addresses to the factory.

If it is true, as Luperini (1981, p. 813) writes, that Albino's devious mind (his "irrazionale razionalita”"), illuminates the pathology of the system (its "razionale irrazionalità"), it is also true that Albino's pathology challenges us to consider a radical new industrial model. As we read before, industry provokes alienation but, as Albino adds, industry has to be controlled, otherwise it will not be the instrument to realize real welfare but it will instead be the way to eliminate humankind. Even if industries provoke alienation and even if they could lead to the extinction of humankind, they can be changed. The awareness of alienation tends to be intertwined with the utopia of an absolute new model of industry.

Albino does not accept any compromise as, on the contrary, the human resources office, the department head, the trade union, and the social assistant do. Albino's extremism deals with a utopia. If the others fight against alienation in order to achieve better conditions, he in fact fights against injustice and thus on behalf of an imaginary model. From that perspective, the strike in which Albino participates in the final part of the novel has a double meaning. On the one hand, the strike is a political and collective act and is thus a reaction against the alienating working 
conditions (this is the "truth" that Albino discovers in the flyer written by the trade union). On the other hand, the strike is a metaphor of self-sacrifice. Albino is not only a victim of the factory (his participation in the strike implies his dismissal), but through his "suicide" he projects into the future the utopia of an opposite model of industry.

\subsection{Concluding Remarks}

The reason that drives Albino to write his memoire is not a wish to denounce the factory where he worked. He writes it to alleviate his pain. The whole novel is constructed around this choice: does Albino's pain coincide with the alienation he feels in the factory? Is that pain a metaphor of the alienation? As I wrote earlier, I think that Albino's pain functions as a lens that provides a better understanding of alienation in the factory but at the same time leads beyond the suffering in the factory. Albino suffers in and out of industry, everywhere. Albino's estranged and delirious voice allows us to better observe the rational/irrational mechanism of the factory but for the same reasons (the power of the mimesis of the inner world, the power of this estranged voice) we perceive the character's will to work as a real possibility to believe in industry and in labor as antidotes to suffering. We perceive Volponi's and Olivetti's utopian idea of industry. Nobody can really help Albino. Is it possible to think of a factory that can help Albino and can thus defeat diseases, discomfort and alienation? Extremely alone and sick, Albino hopes and desires not to be identified with his pain but to be relieved from it. Memoriale invites us to reflect not only on the (real) exploitation and alienation produced by the capitalist industrial system but also on the (utopian) nourishment and familiarity produced by a different industrial system.

Through the story of Albino Saluggia, Volponi invites us also to comprehend the industrial system by going beyond the ordinary model in order to imagine a more human project:

Molta parte della contestazione al sistema e all'industria è stata fatta da posizioni regressive, non di superamento culturale, bensì di nostalgia rurale, di insufficiente coscienza democratica, di mancanza effettiva di cultura e di senso di responsabilità. [...] Il binomio neocapitalismo-industria può essere spezzato perché il neocapitalismo è frutto proprio dell'insufficienza culturale di un certo tipo di organizzazione politica di un vecchio Stato burocratico che non ha capito l'industria. (Volponi 1974b, p. 259) 


\section{Notes}

1. It is useful to note the negative opinion expressed by Vittorini about Memoriale: "uno struggente canto mammista, ben più di Tozzi e Di Giacomo messi insieme." See Nicoletti (2010) and Cavalli (2017).

2. Berardinelli recalls Calvino's judgment: " $\mathrm{Ci}$ rendiamo conto allora di come la tensione lirico-trasfigurativa di Volponi sia la più adatta a esprimere la contraddittoria realtà attuale: tra tecniche industriali avanzate e situazione social-antropologica arretrata, tra fabbriche tutte vetri e acciaio human relations e un'Italia oscuramente biologica" (Calvino 1995, pp. 1277-1278).

3. According to Franco Basaglia (1981), the industrial system (as the power of each "organizzazione di carattere collettivistico") does not cancel the "individual project' as the power of the institution does" (Basaglia 1981, pp. 250-251). See also Rose (2007).

4. Fioretti recognizes the presence of another meaning through an allegorical interpretation of a scene of the novel: "La visione del lavoro industriale in Volponi non è però caratterizzata da una negatività assoluta, ma sembra aprirsi al presagio (o almeno alla possibilità) di una industria non alienata [...] le due scavatrici che si aiutano l'un l'altra nel romanzo sembrano appunto rappresentare questa alternativa possibile" (Fioretti 2013, p. 133).

5. In Musatti et al. (1980). See also Gruppo di prevenzione e igiene ambientale-Cdf Montedison Castellanza (1974), in particular the contributions by Biagioni, Puccetti, Ferrajoli, Pirella, and Basaglia.

\section{REFERENCES}

Bagorda, Anna. 2015. L'alienazione come cura e ricerca nel Memoriale di Paolo Volponi. In Volponi estremo, ed. Salvatore Ritrovato, Tiziano Toracca, and Emiliano Alessandroni, 35-51. Pesaro: Metauro.

Baldacci, Luigi. 1962. Memoriale. Letteratura XXVI (56-57): 135-137.

Barilli, Renato. 1962. Le tentazioni della letteratura industriale. Il Mulino 9: 947-954.

Basaglia, Franco. 1981. La distruzione dell'ospedale psichiatrico come luogo di istituzionalizzazione: Mortificazione e libertà dello "spazio chiuso". Considerazioni sul sistema "open door". In Basaglia, Franco Scritti. I. 1953-1968: Dalla psichiatria fenomenologia all'esperienza di Gorizia, 249-258. Turin: Einaudi.

Berardinelli, Alfonso. 1997. Volponi, uno scrittore diverso. In Paolo Volponi: Il coraggio dell'utopia, Atti del Convegno di Studi, Urbino, 24 maggio 1996Istituto Gramsci Marche and Centro culturale 'La città futura', ed. Massimo Raffaeli, 11-18. Ancona: Transeuropa. 
Best, David Albert. 2015. Volponi-Olivetti e la difesa della civiltà contadina: La macchina mondiale tra ruralismo e cultura industriale. In Volponi estremo, ed. Salvatore Ritrovato, Tiziano Toracca, and Emiliano Alessandroni, 53-73. Pesaro: Metauro.

Bonsi, Claudia. 2015. La fabbrica dei dolori e Il castello di vetro: Volponi e Ottieri allo specchio (ustorio) dell'industria. In Volponi estremo, ed. Salvatore Ritrovato, Tiziano Toracca, and Emiliano Alessandroni, 75-90. Pesaro: Metauro.

Bricco, Paolo. 2009. Olivetti prima e dopo Adriano: Industria, cultura, estetica. Ancona: Ancora del Mediterraneo.

Calvino, Italo. 1995. Memoriale di Paolo Volponi. In Saggi, ed. Mario Barenghi, vol. I, 1273-1279. Milan: Mondadori.

Camon, Ferdinando. 1969. Lettura del Memoriale di Volponi. In Umanesimo e tecnica, ed. Margherita Piva et al., 41-48. Padua: Liviana.

Cavalli, Silvia. 2017. Progetto 'menabò' (1959-1967). Venice: Marsilio.

Ceserani, Remo. 1997. Raccontare il postmoderno. Turin: Bollati Boringhieri.

Chirumbolo, Paolo. 2009. Tra coscienza e autocoscienza: Saggi sulla narrativa degli anni Sessanta. Volponi-Calvino-Sanguineti. Soveria Mannelli: Rubbettino.

Dal Bon, Piero. 1998. Memoriale tra lingua e stile. Studi novecenteschi 55: 95-134.

Debenedetti, Giacomo. 1971. Il romanzo del Novecento. Milan: Garzanti.

Donnarumma, Raffaele. 2014. Ipermodernità. Bologna: Il Mulino.

Fabrizi, Massimo. 1998. Il primo romanzo di Paolo Volponi. Edipo-Narciso e lo "Specchio" della materia: Un memoriale tra Freud e Marx. Rivista di Letteratura Italiana XVI (1-3): 417-437.

Ferrarotti, Franco. 2013. La concreta utopia di Adriano Olivetti. Bologna: Edb.

Ferretti, Gian Carlo. 1966. La letteratura del rifiuto e altri scritti sulla crisi e sulla trasformazione dei ruoli intellettuali. Milan: Mursia.

- 1972. Volponi. Florence: La Nuova Italia.

Fioretti, Daniele. 2013. Carte di fabbrica: La narrativa industriale in Italia (1934-1989). Pescara: Tracce.

- 2017. Utopia and Dystopia in Postwar Italian Literature: Pasolini, Calvino, Sanguineti, Volponi. London/New York: Palgrave.

Forti, Marco. 1989. Volponi romanziere: Cultura e potere industriale, allegoria, poesia. Nuova Antologia CXXIV (2172): 273-302.

Foucault, Michel. 1995. Discipline and Punish: The Birth of the Prison. Trans. Alan Sheridan. New York: Vintage Anchor Publishing.

- 2006. History of Madness. Trans. Johnathan Murphy and Jean Khalfa. London/New York: Routledge.

- 2008. Psychiatric Power: Lectures at the Collège de France, 1973-1974. Trans. Graham Burchell. New York: Picador.

Friedmann, Georges. 1992. The Anatomy of Work: Labor, Leisure, and the Implications of Automation. New Brunswick/London: Transaction Publisher. 
Friedmann, Georges, and Harold L. Sheppard. 1955. Industrial Society: The Emergence of Human Problems of Automation. New York: Free Press of Glencoe.

Gallino, Luciano. 2001. L'impresa responsabile. Turin: Einaudi.

Gigliozzi, Giuseppe. 1996. Memoriale di Paolo Volponi. In Letteratura italiana: Le opere, Il Novecento: La ricerca letteraria, ed. A. Asor Rosa, vol. IV/2, 729-769. Turin: Einaudi.

Giudici, Giovanni. 1962. Il "Memoriale” di Volponi. Comunità XVI (99): 86-89.

Gruppo di prevenzione e igiene ambientale-Cdf Montedison Castellanza, ed. 1974. La salute in fabbrica: Per una linea di gestione della salute nei posti di lavoro e nei quartieri. Rome: Savelli.

Guglielmi, Angelo. 1968. Vero e falso. Milan: Feltrinelli.

Guidotti, Angela. 1998. Lettura di Memoriale. Studi novecenteschi 55: 67-94.

Illich, Ivan. 1976. Medical Nemesis: The Exploration of Health. New York: Pantheon.

Luperini, Romano. 1981. Il Novecento. Turin: Loescher.

Marongiu, Elena. 2003. Intervista a Paolo Volponi. Milan: Archinto.

Masi, Maurizio. 2015. Le poesie di Albino. In Volponi estremo, ed. Salvatore Ritrovato, Tiziano Toracca, and Emiliano Alessandroni, 231-243. Pesaro: Metauro.

- 2016. Il carisma delle idee: Adriano Olivetti ed Anteo Crocioni, per un confronto. Esperienze letterarie 4: 87-118.

Mastropasqua, Aldo. 1995. Una poetica in chiave di utopia. In Paolo Volponi: Scrittura come contraddizione, ed. Gruppo Laboratorio, 13-23. Milan: Angeli.

Musatti, Cesare, et al. 1980. Psicologi in fabbrica: La psicologia del lavoro negli stabilimenti Olivetti. Turin: Einaudi.

Nicoletti, Giuseppe. 2010. Una premessa quasi necessaria: Volponi e il romanzo industriale. Narrativa 31-32: 25-38.

No author. 1962. Otto giudizi sul "Memoriale" e un commento di Volponi. Rinascita, December 8, pp. 25-28.

Ochetto, Valerio. 2009. Adriano Olivetti. Venice: Marsilio.

Pampaloni, Geno. 1980. Adriano Olivetti: Un'idea di democrazia. Milan: Edizioni di Comunità.

Pasolini, Pier Paolo. 1999. Il mostro e la fabbrica. In Saggi sulla letteratura e sull'arte, ed. Walter Siti and Silvia De Laude, vol. II, 2366-2372. Milan: Mondadori.

Pistilli, Manuela. 2014. Paolo Volponi: Uno scrittore dirigente alla Olivetti di Ivrea. Fano: Aras.

Rose, Nikolas. 2007. The Politics of Life Itself: Biomedicine, Power, and Subjectivity in the Twenty-First Century. Princeton/Oxford: Princeton University Press.

Santato, Guido. 1986. Il linguaggio di Volponi tra poesia e romanzo. Paragone XXXVII (442): 8-29.

- 1998. Follia e utopia, poesia e pittura nella narrativa di Volponi. Studi novecenteschi XXV (55): 29-66. 
Sapelli, Giulio, and Davide Cadeddu. 2007. Adriano Olivetti: Lo spirito nell'impresa. Trento: Il margine.

Scrivano, Fabrizio. 2000. Individuo, società e territorio nei romanzi di Paolo Volponi: Le soluzioni narrative di Memoriale e La strada per Roma. Esperienze letterarie 1: 88-104.

Semplici, Stefano, ed. 2001. Un'azienda e un'utopia: Adriano Olivetti 1945-1960. Bologna: Il Mulino.

Spignoli, Teresa. 2012. Tra Freud e Leopardi: Modelli intertestuali nell'opera di Italo Svevo e Paolo Volponi. In Italo Svevo and His Legacy for the Third Millennium, ed. Giuseppe Stellardi and Emanuela Tandello, 1252-1254. Leicester: Troubador.

Spingola, Cinzia. 1997. Paolo Volponi nella scuola: Una promozione marginale. L'immaginazione 143: 34-36.

Tchehoff, Igor. 2015. Memoriale Volponi e Il lebbroso di De Maistre. In Volponi estremo, ed. Salvatore Ritrovato, Tiziano Toracca, and Emiliano Alessandroni, 357-372. Pesaro: Metauro.

Toracca, Tiziano. 2015. Unico protagonista è il potere: Allegorie, personaggi e straniamento nelle Mosche del capitale di Paolo Volponi. Allegoria 71-72: 250-283.

2017. Labour Between Law and Literature: Historical Similarities and Critical Propositions on the Present. Polemos 11 (2): 361-377.

- 2018. Il neomodernismo italiano. In Il modernismo italiano, ed. Massimiliano Tortora. Rome: Carocci.

Vazzoler, Franco. 2004-2005. La fabbrica dei dolori: Albino e Volponi, il memoriale e il romanzo. Istmi 15-16: 83-123.

Vittorini, Elio. 2008. Industria e letteratura. In Letteratura arte società: Articoli e interventi 1938-1965, ed. Raffaella Rodondi, 955-962. Turin: Einaudi.

Volponi, Paolo. 1962. Un unico rimedio: Diffondere la cultura, in Come auspica la civiltà del futuro. L'Illustrazione italiana $\operatorname{LXXX~(6):~45-46.~}$

—. 1964. My Troubles Began. Trans. Belén Sevareid. New York: Grossman.

- 1966. Il movimento operaio ha creato un uomo nuovo. L'Unità, May 31.

- 1967. Non ci credo ma lo farò: Conversation with Manlio Cancogni. La Fiera letteraria, September 21, pp. 5-7.

- 1973. Conversazione critica con Paolo Volponi. In Il mestiere di scrittore, ed. Ferdinando Camon, 123-143. Milan: Garzanti.

— 1974a. A colloquio con Paolo Volponi: Lo scrittore e l'industria. La fiera letteraria, January 20, pp. 10-11.

1974b. Incontro con Paolo Volponi. Il ragguaglio librario, July-August, pp. $258-261$.

. 1977. La letteratura in fabbrica negli anni Cinquanta. In Gli intellettuali in trincea: Politica e cultura nell'Italia del dopoguerra, ed. Saveria Chemotti, 31-40. Padua: Cleup. 
- 1984. Interview with Paolo Volponi. Italian Quarterly XXV (96): 75-89.

. 1995. Per una letteratura di liberazione e di conflitto: Colloquio con Paolo Volponi. Critica marxista 4-5: 79-87.

- 2002. Memoriale. In Volponi, Paolo. Romanzi e prose, ed. Emanuele Zinato, vol. I, 3-232. Turin: Einaudi.

- 2003. Adriano, eretico del capitalismo. In Volponi, Paolo. Romanzi e prose, ed. Emanuele Zinato, vol. II, 645-648. Turin: Einaudi.

Volponi, Paolo, and Francesco Leonetti. 1994. Il leone e la volpe. Turin: Einaudi.

Wells, Maria Xenia. 1997. Memoriale di Paolo Volponi: L'uomo e la fabbrica, esame delle varianti nel manoscritto. In Letteratura e industria, ed. Giorgio Barberi Squarotti and Carlo Ossola, 977-985. Florence: Olschki.

Zinato, Emanuele. 2002. Commenti e apparati. In Volponi, Paolo. Romanzi e prose, ed. Emanuele Zinato, vol. I, 1071-1172. Turin: Einaudi.

. 2015. Il lavoro non è (solo) un tema letterario: La letteratura come antropologia economica. In Zinato, Emanuele, Letteratura come storiografia: Mappe e figure della mutazione italiana, 55-78. Macerata: Quodlibet. 


\section{Psychoanalysis and Alienation}




\title{
Alienation and Psychoanalysis: Some Notes on Italy in the Years of the Economic Miracle
}

\author{
Alessandra Diazzi
}

Although, as Sergio Benvenuto states, "Italy has not produced as many famous 'masters' in this field [of psychoanalysis] as has Austria, Germany, Switzerland, France, Great Britain, the US, and other countries" (Benvenuto 1997, par. 1), in the 1960s the practice of analysis in Italy followed an original path of development, at the same time enjoying great attention in cultural and intellectual circles. The reasons why the couch was put in the spotlight during this decade are related to Italy's sociopolitical situation, which, as we will see, strongly influenced the shape that the discipline took in the country.

This chapter sets out to investigate, first, how Italian psychoanalysis, at the peak of its rebirth, dealt with the notion of alienation, investigating in particular the way in which psychoanalysts established a privileged relationship with factory workers. By doing so, I will also explore the risks intrinsic to the entrance of psychoanalysis into the factory, an aspect that literature has also addressed. Second, this contribution will explain why Italian psychoanalysis had a uniquely committed character, which meant

\section{A. Diazzi $(\bowtie)$}

School of Arts, Languages and Cultures, University of Manchester, Manchester, UK e-mail: alessandra.diazzi@manchester.ac.uk

(C) The Author(s) 2019

A. Diazzi, A. S. Tarabochia (eds.), The Years of Alienation in Italy, https://doi.org/10.1007/978-3-030-15150-8_7 
that, from the 1960s onwards, particular attention was devoted to the social and collective sphere.

Mostly understood in a sociological and ideological sense, and debated extensively in the history of philosophy (Geyer and Schweitzer 1976), the term alienation is not traditionally part of the psychoanalytic vocabulary. Although the word has largely been used in psychiatry to identify states of psychological disturbance, "alienation does not constitute part of Freud's theoretical vocabulary" (Evans 2006, p. 9). It is undeniable that the founder of psychoanalysis explored "civilization and its discontents" (Freud 1930), and subsequently psychoanalytic literature extensively addressed the pathological feeling of detachment from reality and split identity. However, the term alienation has never gained a systematic theorization in psychoanalysis and is consequently rarely employed to pigeonhole psychological disturbances in analytical theory and practice. ${ }^{1}$

A notable exception to this absence appears in the work of Jacques Lacan, in whose oeuvre the notion of alienation recurs. In particular, Chapter 16 of The Four Fundamental Concepts of Psychoanalysis is entirely devoted to a discussion of the concept, which relates to the subject as the subject of desire. Specifically, the term is used to describe the construction of the ego, which, in its early phase, implies an unavoidable state of alienation: "The initial synthesis of the ego is essentially an alter ego, it is alienated" (Lacan 1955-56, p. 39). For Lacan, alienation is an essential condition that necessarily characterizes the imaginary order: "Alienation is constitutive of the imaginary order. Alienation is the imaginary as such" (Lacan 1955-56, p. 146). The alienated state may develop into a psychotic state when the subject's development is disrupted for some reason. However, in Lacanian psychoanalysis alienation in itself does not constitute a pathological condition.

Certainly, psychoanalysis has variously dealt with phenomena that psychiatry usually puts under the umbrella term of alienation, and the word occasionally appears in psychoanalytic literature. However, one can safely state that the notion does not belong to the analytical tradition, and also that the term has not undergone any extensive systematization within the field of psychoanalysis. Undoubtedly, this is not just a matter of terminology; rather, it is a "field demarcation" carried out on the part of psychoanalysis, a spurious knowledge whose epistemological status has always been the object of heated discussion (see Eagle 1989). The lack of a psychoanalytic theory of alienation marks a clear dividing line with Marxism, the historical enemy of the talking cure (see Miklitsch 1998; Conrotto 2006). Moreover, 
the non-inclusion of the term in the psychoanalytic vocabulary means that the discipline set itself apart from both philosophy and psychiatry, a particularly important point when establishing its autonomous status as a theory and a therapeutic technique. Psychiatry and philosophy are, in fact, two fields of knowledge with which psychoanalysis has frequently been assimilated, in an attempt to delegitimize it as an independent discipline.

\subsection{Psychoanalysis, Ideology, and Politics in Italy: An Overview}

In the 1960s Italian psychoanalysis dealt extensively with alienation, seemingly contradicting its previous lack of psychoanalytic systematization. In order to fully understand the reasons for this phenomenon, it is necessary to look back at the controversial history of the discipline in Italy. In particular, it is crucial to clarify the problematic relationship between psychoanalysis, ideology, and politics within the national context.

In 1923 Freud shared with Edoardo Weiss a reflection on Italy and the development of psychoanalysis there. In a letter to his friend and colleague about the country he knew well and deeply loved, he claimed: "I have no doubt that there is a future for psychoanalysis in Italy too. You only have to wait for a suitable time" (quoted in Conci 2008, p. 65).

Written just one year after Fascism seized power in the peninsula, Freud's thought foresees quite lucidly the situation in Italy over the following decades. Whether or not he was consciously referring to the totalitarian regime that had just subjugated the country, the negative impact of Fascism on the development of psychoanalysis in Italy is undeniable. Although the regime never officially suppressed the Italian psychoanalytic institute (SPI), Fascist leaders could not but look suspiciously at Freudian theories. Psychoanalysis had a revolutionary potential, being able to reveal the state of alienation-intended as the total loss of agency of the individual, manipulated as a mere object by the leader-imposed by the regime on the people. As David (1970, p. 47) notes, "il dittatore, cinico e consapevole della base irrazionale su cui poggia la sua forza, difficilmente può ammettere che gruppi intellettuali smascherino pubblicamente le sue nascoste ragioni: la folla manipolata da lui e identificantesi nascisisticamente con lui, non deve poter prendere coscienza di questa alienazione." Furthermore, psychoanalysis was conceived as a luxury for bourgeois, neurotic, souls, as well as a decadent and dangerous cure that 
had been imported from northern Europe. The talking cure was seen, on the one hand, as a fashionable treatment for hysterical crisis-women (donne-crisi), as opposed to the balanced, "floridly robust and tranquil" model of the donna-madre (Chang 2015); and on the other hand, it clashed with the idea of the new Fascist man, Mussolini's idea of masculinity characterized by a solid and strong virility. The regime's hero therefore had no interest in his inner life and psyche. An inward and introverted attitude was perceived as a form of feminine weakness, which had the potential to threaten the ideal of a brave soldier entirely devoted to the patria. Moreover, psychoanalysis was-and was regarded as-stemming from a Jewish background, and the majority of psychoanalysts working in Italy were indeed of Jewish origin. As a result, with the implementation of racial laws in 1938, analysts were forced to abandon their profession and the SPI to stop its activities.

It is therefore clear that since the early phase of dissemination in the twentieth century the diffusion of psychoanalysis in Italy was jeopardized and, later on, completely blocked for political reasons. The fall of Fascism and the end of World War II in 1945 paved the way for the return of psychoanalysis to the country and for the reconstruction of the SPI. In 1946 the Italian pioneers of psychoanalysis-Cesare Musatti, Nicola Perrotti, and Emilio Servadio-returned to the clinical setting. Communication and exchanges between such notable Freudian scholars could start again. 1946 also witnessed the three aforementioned father-founders reestablishing the SPI in Rome, again founding an officially Italian Freudian school. The first national congress of the SPI was held in Rome in the same year, formally celebrating the rebirth of psychoanalysis on the peninsula.

Although at this stage Italy seemed to provide fertile soil for a widespread dissemination of the discipline, the return of the couch in the postwar years was far from being unproblematic. Once again, resistance to the diffusion of psychoanalysis in the country had ideological roots.

As mentioned in the introduction to this volume, in the postwar years the Partito Comunista Italiano (PCI, Italian Communist Party) managed to conquer and maintain a large consensus, although it never won elections. As such, it profoundly influenced Italian culture, to the extent that we can speak of a Communist and Marxist intellectual hegemony dominating the country up to the late 1970s (see Gundle 2000).

This situation created an unfavorable climate for psychoanalysis, since leftist intellectuals - especially those anchored to more radical positionsdid not appreciate it. For them, in fact, its inward look and focus on the 
private sphere clashed with the extroverted attitude and public engagement they promoted - that is to say, the impegno they considered a moral imperative. Providing an overview of the reception of psychoanalysis in Italy, David (1970, p. 72) notes this resistance coming from the Italian left: "Gli intellettuali comunisti erano stati in grandissima parte dei gentiliani e dei crociani, e questa formazione filosofica li portava, oltre che a una generale diffidenza verso la psicanalisi, a un modo astratto di aggredire i problemi che non fossero strettamente politici." As a result, Communist thinkers considered the practice of analysis to be:

Un'ideologia conservatrice, mistificatrice, oscurantista, irrazionale $[\ldots]$ una scienza solo in apparenza, una mitologia senza nessun apporto positivo; uno strumento di intervento politico; un mezzo paralizzante per ogni progresso sociale, il quale placa le malattie borghesi e incretinisce le masse; una tecnica di evasione e perversione che purtroppo è penetrata in tutti i rami del sapere. (David 1970, p. 74)

If the long-lasting dispute between psychoanalysis and Marxism is a broader phenomenon that exceeds Italian boundaries, what is peculiar about the national case is the character of resilience that psychoanalysis demonstrated in order to survive the unfavorable climate.

When, in 1948, one of the first postwar psychoanalytic reviewsPsiche-began publication, its founder, Nicola Perrotti, made clear that psychoanalysis was not a purely private matter but, rather, an interpretative framework that could be applied to the public and social sphere:

Ma è lecita la domanda: se il popolo italiano, malgrado questi tentativi di auto guarigione, dà l'impressione di essere affetto da una nevrosi collettiva, che cosa si può fare per cercare di guarirlo? Anche in questo caso l'analogia con la nevrosi individuale è perfetta. (Perrotti 1948, p. 17)

Far from being an isolated case, limited to Psiche's approach to psychoanalysis, this opening of the discipline to the collective domain was a welldefined trend that characterized Italian psychoanalysis in the postwar years and, in particular, in the 1960s.

This phenomenon is lucidly addressed by the Italian psychoanalyst and psychiatrist Giovanni Jervis, who, in 1964, wrote the introduction to the Einaudi edition of the American volume Social Class and Mental Illness (1958). If Einaudi's decision to publish a book that "si propone 
di stabilire in che maniera fattori storici, economici e culturali influenzano l'insorgere e l'evolversi delle malattie psichiatriche" (Einaudi's bibliographical presentation sheet, no page number) is significant in itself, the introductory chapter is even more significant in terms of understanding the direction that Italian psychoanalysis had taken by then. Here, Jervis criticizes Freud in that "il parere sostanzialmente pessimista espresso da Freud sul malessere psichico imposto dal progresso e dall'ordine societario non assunse mai il carattere di un giudizio storico [...] per aggirarsi invece nell'ambito di un discorso antropologico e filosofico generale" (Jervis 1965, p. xxii). Instead, Jervis stresses the importance of applying social and historical correctives to Freudian theories, which tended "a dissolvere i problemi storici, la storicità stessa dell'uomo in una tematica universale" (Jervis 1965, pp. xxvi-xxvii). It is fundamental for him to consider "l'ipotesi che fattori sociologici legati alla vita moderna possano essere causa di un disagio soggettivo (la nevrastenia) psichiatricamente definito" (Jervis 1965, p. xxii).

In order to be integrated within the coeval cultural context, psychoanalysis in Italy, from being a treatment exclusively for the neuroses of the individual, became-as Fachinelli would claim later on-more and more "socializzata nei fini" (Fachinelli 1970, p. 17). It thus became an interpretative framework through which to examine, and possibly cure, society and its discontents.

\subsection{Alienation in the Years of the Miracle}

While in the immediate postwar years, psychoanalysis found a political use as an interpretative framework for understanding the reasons why Italy had been subjugated by Fascism (see David 1970, pp. 33-46), in the 1960s the "collective neurosis" affecting the country radically mutated. Over this decade, and between 1958 and 1963 in particular, Italy experienced a time of dramatic and unexpected economic growth, which corresponded with exceptional changes at all social levels.

On the one hand, this sudden economic wealth triggered a shared sentiment of optimism, and feelings of excitement and euphoria. On the other hand, the Italian boom was not a balanced and homogeneous progress: the North-South divide got worse; the phenomenon of uncontrolled immigration began, with southern workers finding themselves living in peripheral areas of large and estranging northern cities; and, to complicate the 
situation further, the Italian government revealed itself unable to control the country's new life, or to guide or balance such unparalleled growth.

The economic boom was, therefore, not only a miracle. Italians' enthusiasm went hand in hand with feelings of estrangement. On the one hand, a sentiment of alienation affected workers moving from the South, who found themselves living in low-income blocks of flats built on the outskirts of industrial cities, not only detached from their home towns and families but also "exiled" within immigrant communities (see Ginsborg 1990, pp. 217-229). On the other hand, the nation as a whole was overwhelmed by the dramatic changes that radically transformed the country's morphology and geography. Non-places, such as autogrill (motorway service areas) and superstores, which became ubiquitous throughout the peninsula, gradually erased the "old Italy," provoking a feeling of estrangement in people, who suddenly felt like foreigners in their own country. Furthermore, "Italy's experience with modernity has transpired in the 'all'italiana mode," which has corresponded with a widespread psychological rejection of the process of industrialization and transformation of the country (Di Renzo and Warshay 1991, p. 161). Undeniably, the neo-capitalist society was perceived as a miracle concealing "un volto bifronte: concede benessere ma sottrae libertà, si prende cura della vita dei suoi dipendenti, però nel contempo elegge a codice etico la mistificazione dei rapporti, il confondere obiettivi e promesse, il seguire una logica spesso erronea" (Lupo 2016, p. 36). As a result, as soon as Italy turned into a neo-capitalist power, the country also became fertile ground for a collective state of alienation, whose effects were even more devastating because of the sudden and unexpected nature of the boom. The miracle corresponded with "l'iniziazione della società italiana $[\ldots]$ ai riti alienanti della società dei consumi" (Saibene n.d.). Although this period of Italian history is mostly described by scholarship as a time of optimism and euphoria (see, for instance, Mafai 1997; Castronovo 2010), alienation was spreading as the malady of the new, modernized, Italy across all social classes. Alienation affected both those who were the protagonists of the boom, overwhelmed by the "dictatorship" of consumerism and neo-capitalism, and those who, instead, were exploited by the boom, subjugated by the exhausting industrial pace and living in precarious conditions. Despite the exceptional growth that the country enjoyed, in sum the economic boom certainly inaugurated "the years of alienation." 


\subsection{Psychoanalysis and the ECONOMic BoOM: Depersonalization and Industrial Alienation}

Despite the resistance that psychoanalysis triggered on its reappearance in the country after the war, in the 1960s the situation was, at least partially, transformed. First of all, after the initial difficulties in the immediate postwar years owing to unfavorable socioeconomic conditions (see Ginsborg 1990, pp. 210-211), psychoanalysis:

Trovò uno spazio sempre più ampio nella società e nella cultura italiana degli anni ' 60 , grazie non tanto ai risultati conseguiti nei pochi centri universitari di ricerca allora esistenti, ma al dibattito che si accese in relazione a temi di interesse più generale, che attenevano sia alla cura dell'anima individuale che a problemi di natura sociale e politica. (Mecacci 2012, p. 733)

The increased economic wealth and, concurrently, the trauma caused by the boom, led Italians - especially middle-class people - to find in psychoanalysis the aid to cope with the ongoing transformation. In the years of the miracle, psychoanalysis turned, for those who could afford such an expensive cure, into a way "[per] dare voce al disagio psicologico e al malessere sociale che accompagnavano il boom economico, l'industrializzazione e i sempre più rapidi cambiamenti di costume" (Muzzarelli 2014, p. 82). This "boom" is not surprising, if one observes with Parker that "psychoanalysis came into being as a psychological practice to address the particular forms of alienation that capitalism produced; psychoanalysis and capitalism are twins, even if one can be used to highlight contradictions in the other" (Parker 2007, p. 178).

The success that psychoanalysis enjoyed during the boom was not, however, exclusively due to the psychological needs triggered by the socioeconomic situation or, in other words, to an increase in demand. During this delicate time for the nation, psychoanalysis also turned its attention to society. The twenty-first Congresso di psicoanalisti di lingue romanze is a paradigmatic example in this respect. In 1960, at the peak of the boom, this was held in Rome. The theme of the congress, which Italian and international psychoanalysts gathered to discuss, was depersonalization (depersonalizzazione or spersonalizzazione in Italian), a psychological disorder that also has social implications. 
Clinically, the terms "depersonalization" and "alienation" are certainly not interchangeable. However, the two notions have a certain kinship. Some of the symptoms that patients affected by depersonalization describe-feeling that the external world and the subject's identity are transforming; a sense of estrangement and split self; an impression of detachment toward an unrecognizable reality (de Mijolla 2005, p. 393) are also those that characterize states of mental alienation. Not by chance, in The First Dictionary of Psychoanalysis (Sterba 2013) the English word "depersonalization" is one of the terms that translates the German heading Entfremdung, which also means "alienation." The proximity of the two notions is further confirmed by the fact that "the term depersonalization has also been used to refer to social alienation resulting from the loss of individuation in the workplace and the community" (Sofroniou 2015, p. 142). Depersonalization is therefore a notion that, although it mostly concerns subjectivity, at the same time implies references to the individual's relationship with the public sphere and his/her role in society.

These very basic coordinates on the idea of depersonalization suffice to clarify the reason why the theme of the congress has fundamental relevance in this context. For psychoanalysts, debating depersonalization meant exploring the clinical manifestations of alienation, at the same time engaging with a concept that-differently from alienation-frequently recurs in Freud's work (de Mijolla 2005, p. 393).

This focus enables clinicians to, first, tackle the phenomenon of alienation from an analytical perspective, without engaging directly with a concept overly defined in a Marxian sense. For psychoanalysis, avoiding intrusion into the Marxist field and marking a definite dividing line between the two disciplines was in fact a fundamental point in the dispute with Marxism, and crucial to maintaining the credibility and legitimacy of the practice of analysis for leftist culture. Musatti, in fact, believed that "non era possibile una conciliazione tra la psicoanalisi e il marxismo, trattandosi di due concezioni dell'uomo diverse rispetto alla retrostante tradizione filosofica" (Mecacci 2012, p. 734).

Secondly, dealing with depersonalization meant treating the private sphere and the individual domain of psychopathology without losing sight of the social sphere. In the years of the boom, a mental disorder based on the impression that the world had become different and extraneous (de Mijolla 2005, p. 393) was not exclusively a subjective matter. On the contrary, for a country in the middle of such a radical transformation, the feeling that reality had turned into an unrecognizable universe could 
easily be translated on a collective scale. Depersonalization therefore took the shape of a mental disturbance whose aetiology was to be referred not only to psychological factors but also-and, on some occasions, primarily-to environmental reasons.

The attention that Italian psychoanalysis devoted to the social genesis of psychological disorders was therefore not limited to theoretical discussion.

The opening of the discipline toward a collective dimension took the shape of a concrete project to be carried out outside psychoanalytical circles and private spaces. The promotion of a "social way" for psychoanalysis envisaged the project increasing the number of people who could benefit from this kind of treatment. In particular, the goal was to bring the talking cure to workers. This was a revolution, considering that the working class was usually excluded, for financial and cultural reasons, from the privilege of receiving a type of psychological help that was radically different from institutional psychiatry in its approach to the patient. If, as we have seen, alienation was the malady of the boom, psychoanalysis in Italy was not just a fashionable cure for middle-class neuroses triggered by the new consumerist - and neo-capitalist - habits. On the contrary, the practice of psychoanalysis also explored, and aimed to mitigate, the so-called "industrial alienation" of workers who were overwhelmed by factory shifts and piecework exhaustion. "Putting Italy on the couch" meant, in sum, giving everyone-beyond class boundaries - the possibility of working through the mental state of alienation, challenging the prejudice of psychoanalysis as a cure for wealthy bourgeois individuals.

Ivrea, the central hub of the economic boom, was the northern city in which opening up psychoanalysis to the working class first started as a pioneering experiment. The Italian psychoanalyst Cesare Musatti was the protagonist-together with Adriano Olivetti-of the revolutionary introduction of psychology and psychoanalysis into the factory. According to Olivetti, tools borrowed from the field of psychological and psychoanalytical studies, adapted to the industrial dimension, were crucial to fulfill his dream of a more human, dealienated, factory. Although Olivetti died in 1959, aged fifty-eight, the project of bringing psychoanalysis into the industrial dimension had started before the war and, despite his premature death, found its full development in the years of the boom.

The employment of analysts within the factory, and the application of analytical instruments to the industrial world, were regarded by clinicians as a form of political commitment, perceived as an active "impegno nella 
lotta che la classe operaia conduce per sottrarsi allo sfruttamento del padronato e per modificare il sistema entro il quale tale sfruttamento si compie" (Musatti 1976, p. 326). At the same time, the awareness that industrial alienation was a pathological, rather than ideological, issue was explicit: "Il problema della nevrosi nell'industria [è] un problema tecnico, che va risolto sul piano tecnico e non su quello ideologico" (Musatti 1976, p. 326). Although the employment of psychoanalysts within the factory was ideologically connoted and described as a contribution to the workingclass struggle, Musatti explicitly stresses the difference between social and mental alienation. In so doing, he makes it clear that psychoanalysis primarily treats the psychological side of this condition only, without ignoring, however, the economic and social factors fueling this pathological state in workers:

Circa il problema dell'alienazione nel lavoro, va tenuta presente la plurivocità del termine.

Altro è l'alienazione in senso economico, il fatto cioè che il lavoratore vende la propria attività di lavoro, e lavora per il profitto altrui, ed altro è l'alienazione in senso psicologico, per cui l'operaio anzi che identificarsi col proprio lavoro, eseguisce [sic] il lavoro stesso in forma meccanica, automatizzandolo, e rimanendo spiritualmente estraneo e assente. La alienazione in senso psicologico è indubbiamente dannosa, in quanto schizofrenizzante. Favorisce cioè una impostazione per cui il soggetto si immerge in un'atmosfera di sogno e di fantasia, restando distaccato dalla realtà. Se questa impostazione si prolunga al di là del periodo di lavoro, si instaura una condizione psicotica. (Musatti 1976, p. 327)

Psychoanalysis was employed in various ways as an aid to mitigate and cure the disorders related to the state of alienation caused by factory labor.

First, it was used for the evaluation of workers within the area of human resources. Psychoanalysts and psychologists were called upon to elaborate interview strategies and psychometric tests, used to understand candidates' skills and ambitions in order to match them with the best possible roles within the factory. The aim of this process was to make workers aware of the importance of their own qualities, thereby dismantling the feeling of being tools at the service of the industrial system. Moreover, distributing jobs according to workers' skills, and, when possible, their desires, improved their performance-which meant both happier employees and a more productive factory. 
Second, clinicians were asked to evaluate the space of the factory itself, the organization of work within that space, workers' daily schedules, and their relationships with colleagues and bosses. This was meant to identify those aspects of the industrial environment that might negatively affect employees' mental health and, consequently, their productivity. In Musatti's own words:

Individuare e segnalare gli elementi tecnici, da un punto di vista psicologico, suscettibili di migliorare le condizioni di vita e di lavoro dell'operaio. [...]

È del tutto inutile dichiarare genericamente responsabili delle nevrosi industriali, la fabbrica, o lo sfruttamento di cui il lavoratore è oggetto nel nostro sistema economico. Occorre invece determinare i fattori specifici che agiscono come cause scatenanti della nevrosi. E non si può a tale proposito usare un linguaggio impreciso, mescolando insieme semplici stati di sovraffaticamento e tipiche forme di psiconevrosi. [...] E le circostanze attuali scatenanti vanno ricercate, oltre che nelle modalità tecniche del lavoro (lavoro ripetitivo, tempi eccessivamente stretti, frustrazioni di ogni specie ecc.) nei rapporti con i compagni di lavoro, o con i capi intermedi, che riproducono le situazioni infantili di conflitto, vero o immaginato, con i fratelli, con i genitori, o con coloro che comunque ne hanno esercitato le funzioni. (Musatti 1976, pp. 326-327)

Individuating psychological and environmental factors that triggered the state of alienation, clinicians provided psychological support for workers, a service that was part of the innovative idea of welfare aziendale (company welfare) that Olivetti pursued. ${ }^{2}$

The entrance of psychoanalysis as an evaluation instrument within the space of the factory, and the introduction of a system of psychological care provided by the company, were far from being unproblematic, however.

What Parker observes on work psychology can also be applied to the relationship between psychoanalysis and the factory in the 1960s: "There are many instances in the history of psychology that reveal the class interests of the discipline. It sides with the employers and the drive for the maximization of profit, and against workers and the possible democratic collective ownership of production" (Parker 2007, p. 64). The suggestions that clinicians made with the aim of creating a more human factory only had a chance of being approved when the proposed changes did not clash with the logic of profit, production, and performativity, as Musatti himself makes clear: 
Qualunque sia la sua posizione ideologica, lo psicologo deve parlare il linguaggio dell'azienda, che-nel nostro mondo-è per forza il linguaggio del profitto. [...] Per migliorare le condizioni dell'operaio lo psicologo non può che rivolgersi alla direzione aziendale, e se vuole ottenere qualcosa da questa deve dimostrare, col linguaggio dei costi, che un tale miglioramento può significare: una flessione dell'assenteismo, un allungamento del tempo di permanenza nell'azienda, una minore incidenza dei tempi di apprendimento del lavoro, una riduzione della morbilità, sia nei confronti di malattie organiche che di disturbi nevrotici. (Musatti 1976, p. 327)

As a result, although psychoanalysts involved in the project saw employment in factories as a form of political commitment, attempts that were made to mitigate the feeling of alienation stemming from labor and to make the factory a welcoming space could also be interpreted as a conservative, and even repressive, use of psychoanalysis. In other words, "curing alienation" might have the effect of suppressing those feelings of discomfort and unease that eventually turned workers against the system that was provoking them. The aim of bringing psychoanalysis into the factory would therefore be adapting the working class to industrial necessities: "Even the moments of unhappiness that could lead us to reflect on what is wrong with the world are turned into signs of pathology that must be blotted out; alienation in psychological culture is thus reinforced and any awareness of it is suppressed" (Parker 2007, p. 111). Attempting a parallel with Basaglia's critique of the asylum, in this context psychologists and psychoanalysts can become "funzionari del consenso" (Basaglia 1975, p. 241), who on the one hand aim to improve work conditions but on the other contribute to making workers accept the objectification they are subjected to in factories. As Rozzi put it, when entering the factory, psychoanalysis "ha per scopo l'adeguazione di una sovrastruttura (soggettiva) ad una struttura (oggettiva)" (Rozzi 1977, p. 33).

The collaboration between psychoanalysts and industrialists therefore risked producing a different kind of alienation, more ambiguous in its being a more subtle and concealed oppression: a form, in sum, of gratitude and dedication toward the factory now seen-again borrowing a Basaglian notion-as a "golden cage" (Basaglia 1964).

Industrial literature lucidly depicts the more ambiguous aspects of an institution - the factory - that provokes and, at the same time, aims to cure the sentiment of alienation in its workers. 
Employed at Olivetti's branch in Pozzuoli as a psicotecnico (psychology technician), Ottieri recounts and fictionalizes this experience in Donnarumma all'assalto (1959). Although hired to recruit workers, he clearly describes the role of psychoanalyst that he ends up taking, every day meeting desperate people who need to be listened to, rather than evaluated and assessed as workers or potential employees. By exploring the psyche of workers and applicants, Ottieri gradually understands that, by providing a service of care and even protection, the factory is idolized as a space of salvation:

Sulla collina, sopra il paese, esce, sorge la fabbrica: come un castello orizzontale di vetro, fluorescente di luci fredde. C'è il neon dietro i vetri. Gli abitanti della costa, i pescatori, possono vederla così irraggiungibile da ogni punto del golfo. La collina sterposa non è più uno di quei bozzi, foruncoli coni vulcanici esplosi in una notte, che salgono e scendono in mezzo ai laghi di dei crateri, meravigliando i turisti e lasciando a bocca asciutta gli indigeni, ma un palazzo proibito. Ci si lavora sicuri, alla meccanica pulita. (Ottieri 1963, p. 88)

On the one hand, Ottieri makes it clear in his later book La linea gotica (1962) that efforts to turn the factory into a more human, non-alienating, environment were effective, to the extent that the equivalent industrial work alienation seems to have been fully dismantled:

Tutti i termini del mondo industriale sono, da principio, stravolti. Si agogna a lavorare in fabbrica come ad una salvezza totale. La fabbrica è un luogo di delizie, in confronto alla disoccupazione, a tutti gli pseudo-mestieri, all'antichissimo 'arrangiarsi'; luogo di dignità, onore, ricchezze. Fa ridere parlare di alienazione a chi darebbe l'anima per diventare operaio. (Ottieri 1962, p. 169)

On the other hand, he describes the ambiguous effects of turning the factory into a domestic environment, a process that deprives the workplace of its subversive potential and ideological connotations:

Forse negli ultimi tempi la fabbrica era troppo una casa. Moriva il significato politico di essa, come esperimento di industria moderna del mezzogiorno, come accensione di una nuova vita operaia: non la giudicavo più, non mi sdegnavo più, preso dal suo giro, affondato nel suo fascino quotidiano. (Ottieri 1963, p. 224) 
Enzo Morpurgo, psychoanalyst and psychiatrist, tried to overcome these controversial aspects affecting the project of working-class psychoanalysis. In 1969 he opened the first consultorio popolare (affordable counseling service) in Niguarda, a working-class district in Milan. Whereas Musatti's centro di psicologia del lavoro (center for work psychology) at Olivetti developed a project of assistance and support in collaboration with the company, Morpurgo's center had no connection whatsoever with the factories where the worker-patients were employed. The Niguarda counseling center was able to offer free analytical sessions to workers and their families living in the area. The center's goals were, however, broader, in that Morpurgo's team aimed, through analytical lenses, to examine labor organization, social structures, and economic conditions as crucial factors in understandingand curing - the problem of alienation in contemporary society. As Mirella Curi Novelli, Morpurgo's collaborator, put it, the objective was not only "proporre soluzioni terapeutiche, ma [...] esplorare il modello di organizzazione sociale riconoscendo, nella divisione in classi e nell'organizzazione del lavoro, le cause dell'alienazione e della malattia mentale" (Voltolin 1996, p. 53). This goal mirrors Morpurgo's understanding of the encounter between psychoanalysis and Marxism. Whereas, for Musatti, the two were to be treated as two different "rivoluzioni copernicane" (Musatti 1976, p. 133), and psychoanalysts working in factories had to keep separate their clinical practice and ideological beliefs, Morpurgo disagrees with this view. For him, "marxismo e psicoanalisi non sono discorsi ma prassi trasformative [che] funzionano in modo convergente e sinergico" (Spiweb 2013). According to Morpurgo, putting psychoanalysis at the service of the working class therefore means turning it into a crucial instrument of the Marxist revolution, an instrument that acts on individual consciousness to empower class consciousness. The talking cure becomes fundamental to making workers aware of the condition of alienation that they suffer, both as a psychological disorder and as a social malady.

\subsection{Conclusion}

Analysis of the attention that Italian psychoanalysis devoted to alienation - in the twofold understanding of the notion, subjective and collective-has allowed us to understand, on the one hand, the development of the discipline in the peninsula, and on the other hand, has revealed the controversial aspects of the economic boom, perceived at the same time as a miraculous time for Italy and as an alienating metamorphosis of society. 
The focus on alienation hereby discussed should primarily be related to the coincidence between the boom of psychoanalysis in Italy and the country's economic boom. This demonstrates the significant impact of Italy's sociopolitical situation on the practice of analysis, whose development in the country was profoundly affected by political and ideological factors. As a result, the attention of psychoanalysis, since the early phases of its postwar rebirth, turned to society, and care was taken not to separate the analysis of personal suffering from the examination of collective manifestations of psychological discomfort. Clearly, alienation was, par excellence, the bridge between private and public forms of an altered mental state. Addressing alienation therefore enabled Italian psychoanalysis to develop a peculiar "committed character," which allowed the discipline not to clash with the imperative to impegno dominating Italian culture and society at the time. The focus on alienation on the part of psychoanalysis can therefore be related to what Benvenuto describes as the tendency to "extroversion" of Italian culture, a context in which "the highest model for an Italian intellectual was and is, even today, political commitment in the agora" (Benvenuto 1997, par. 2). Debating alienation with its psychological and social implications allowed psychoanalysts to turn from being clinicians only, whose action was limited to the private space of setting, to organic intellectuals who could make their voice heard publicly.

This also signals that the Marxist resistance to psychoanalysis in the early postwar years did not jeopardize the diffusion of the discipline in the country in the following decades. On the contrary, this context impressed a peculiar shape onto the diffusion of the practice of analysis, which adapted itself to this ideologized sociocultural context.

The result of this process of adjustment is the original development of a psychoanalysis of work, as well as a working-class psychoanalysis, whose most paradigmatic examples are-as we have seen-Olivetti's psychological center in Ivrea and Morpurgo's counseling service in Milan.

Despite the risk of normalization and even repression that a clinical approach to social alienation may carry, the debate on the matter from an analytical angle has brought to light the social character of Italian psychoanalysis, its interest in the environmental aspects of psychological development, and the struggle to overcome its bourgeois heritage.

Although, as David claimed in 1970, "la malattia mentale [è] ancora meno sentita in Italia di quella sociale" (David 1970, p. 17), the work on alienation that psychoanalysis carried out in the 1960s must be read as a concrete-and, in some of its aspects, revolutionary-attempt to bridge the gap between private neuroses and social discontent. 


\section{Notes}

1. The absence of the term in Laplanche's and Pontalis's dictionary of psychoanalysis, translated into English as The Language of Psychoanalysis (1973), confirms the lack of a systematization of the term in Freudian and postFreudian psychoanalysis.

2. The Olivetti company offered to employees a variety of services that supported them and their families (accommodation, nurseries, holiday camps for children, an enhanced maternity leave). For more on this theme see Ciuffetti and Trisoglio (2017).

\section{REFERENCES}

Basaglia, Franco. (1964) 2017. La distruzione dell'ospedale psichiatrico come luogo di istituzionalizzazione. In Basaglia, Franco. Scritti 1953-1980, 261-270. Milan: ilSaggiatore.

- (1975) 1981. Crimini di pace. In Basaglia, Franco. Scritti 1953-1980, 707-790. Milan: ilSaggiatore.

Benvenuto, Sergio. 1997. Italy and Psychoanalysis. Journal of European Psychoanalysis 5 (Spring Fall). http://www.psychomedia.it/jep/number5/ benvenuto.htm

Castronovo, Valerio. 2010. L'Italia del miracolo economico. Bari: Laterza.

Chang, Natasha. 2015. The Crisis-Woman: Body Politics and the Modern Woman in Fascist Italy. Toronto: University of Toronto Press.

Ciuffetti, Augusto and Fabrizio Trisoglio, eds. 2017. Welfare aziendale nell'Italia del secondo dopoguerra: Riflessioni e testimonianze. Milan: Egea.

Conci, Marco. 2008. Italian Themes in Psychoanalysis: International Dialogue and Psychoanalytic Identity. International Forum of Psychoanalysis 17 (2): 65.

Conrotto, Francesco. 2006. Statuto epistemologico della psicoanalisi e metapsicologia. Rome: Borla.

David, Michel. 1970. La psicoanalisi nella cultura italiana. Turin: Boringhieri.

de Mijolla, Alain. 2005. International Dictionary of Psychoanalysis. Detroit: Macmillan Reference.

Di Renzo, Gordon, and Leon Warshay. 1991. National Character and Psychological Modernity in Italy. International Social Science Review 66 (4): 158-168.

Eagle, Morris. 1989. The Epistemological Status of Psychoanalysis. Social Research 56 (2): 383-419.

Evans, Dylan. 2006. An Introductory Dictionary of Lacanian Psychoanalysis. London: Routledge.

Fachinelli, Elvio. (1970) 2011. Lo psicoanalista deve definire la sua posizione nella società. Aut Aut 352: 11-20. 
Freud, Sigmund. (1930) 2002. Civilization and Its Discontents. Trans. James Strachey. London: Penguin.

Geyer, Felix, and David Schweitzer, eds. 1976. Alienation Theories and De-alienation Strategies: Comparative Perspectives in Philosophy and the Social Sciences. Leiden: Martinus Nijhoff Social Sciences Division.

Ginsborg, Paul. 1990. A History of Contemporary Italy: Society and Politics, 1943-1988. London: Penguin Books.

Gundle, Stephen. 2000. Between Hollywood and Moscow: The Italian Communists and the Challenge of Mass Culture. Durham/London: Duke University Press.

Hollingshead, August, and Fredrick Redlich. 1958. Social Classes and Mental Illness. New York: Wiley.

Jervis, Giovanni. 1965. Introduzione. In Classi sociali e malattie mentali, ed. August Hollingshead and Fredrick Redlich, xi-lv. Trans. Giovanni Jervis. Turin: Einaudi.

Lacan, Jacques. (1955-56) 1977. Seminar XI: The Four Fundamental Concepts of Psychoanalysis. Trans. Alan Sheridan. London: The Hogarth Press and the Institute of Psycho-Analysis.

Laplanche, Jean, and Pontalis, Jean-Bertrand. 1973. The Language of Psychoanalysis. Trans. Donald Nicholson-Smith. London: Hogarth Press and the Institute of Psycho-Analysis.

Lupo, Giuseppe. 2016. La letteratura al tempo di Adriano Olivetti. Ivrea: Edizioni di Comunità.

Mafai, Miriam. 1997. Il sorpasso: Gli straordinari anni del miracolo economico, 1958-1963. Milan: Mondadori.

Mecacci, Luciano. 2012. Cinquant'anni di psicologia in Italia. Giornale Italiano di Psicologia 39 (4): 729-741.

Miklitsch, Robert, ed. 1998. Psycho-Marxism: Marxism and Psychoanalysis Late in the Twentieth Century. Special Issue, South Atlantic Quarterly. Vol. 9. 2nd ed. Durham: Duke University Press.

Musatti, Cesare. 1976. Riflessioni sul pensiero psicoanalitico. Turin: Boringhieri.

Muzzarelli, Andrea. 2014. Il guaritore ferito. Rome: Armando.

Ottieri, Ottiero. (1959) 1963. Donnarumma all'assalto. Milan: Garzanti.

- 1962. La linea gotica. Milan: Bompiani.

Parker, Ian. 2007. Revolution in Psychology: Alienation to Emancipation. London/ Ann Arbor: Pluto Press.

Perrotti, Nicola. 1948. Problemi psicologici del popolo italiano. Psiche 1: 11-23.

Rozzi, Renato. 1977. Psicologi e operai: Soggettività e lavoro nell'industria italiana. Milan: Feltrinelli.

Saibene, Alberto. n.d. L'Italia nel miracolo economico (1958-1963). http://www. doppiozero.com/materiali/made-in/l-italia-del-miracolo-economico-1958-1963. Accessed 14 Aug 2018.

Sofroniou, Andreas. 2015. Therapentic Psychology. London: Lulu. 
Spiweb. 2013. Enzo Morpurgo: Attualità e inattualità del suo pensiero. https:// www.spiweb.it/eventi/enzo-morpurgo-attualita-e-inattualita-del-suo-pensiero/. Accessed 3 Aug 2018.

Sterba, Richard. 2013. Dictionary of Psychoanalysis: A Gift for Sigmund Freud's 80th Birthday. Trans. Peter Hoffer. London: Karnac Books.

Voltolin, Adriano, ed. 1996. Elogio della psicoanalisi. Milan: Franco Angeli. 


\title{
Psychoanalysis in Milan in the Age of Dis-alienation: The Case of Elvio Fachinelli
}

\author{
Pietro Barbetta
}

\subsection{INTRODUCTION}

In this chapter I outline the problem of alienation (Barbetta 2015a) in relation to psychoanalysis in Italy during the 1960s, 1970s, and 1980s, with particular reference to Elvio Fachinelli (1928-1989), a leading figure amongst the psychoanalysts who critically revised the classic psychoanalytic setting. According to Fachinelli, this was a space of alienation. He was particularly concerned about the relationship between the psychoanalyst and the person who attends the therapy (i.e. the patient/client). Fachinelli sees the classic setting as a kind of expropriation of the patient's knowledge/power from their body and life by the analyst, who uses expertise and the privilege of supposed knowledge (e.g. the Oedipal Triangle) as a paradigm through which the patient's words, dreams, lapses, and so forth are interpreted as symptoms. ${ }^{1}$ In orthodox Freudian psychoanalysis, symptoms and Ego-structure are ultimately reduced to sexual desire framed within the classic Oedipal Triangle. Fachinelli's critique was focused on the Oedipus complex. He regarded it as a theory that turned rapidly

P. Barbetta $(\bowtie)$

University of Bergamo, Bergamo, Italy

e-mail: pietro.barbetta@unibg.it

(C) The Author(s) 2019

A. Diazzi, A. S. Tarabochia (eds.), The Years of Alienation in Italy, https://doi.org/10.1007/978-3-030-15150-8_8 
into a dogma that reduced therapeutic practice to a kind of bourgeois confession of incestuous desires. For this reason, he proposed a new setting for the psychoanalytical encounter, where desire is connected to the social world and the subject is seen as a collective being rather than as monadic individual independent from social structures. Factories, schools, public spaces, hospitals, family homes, and even streets, became an enclave where psychotherapy could work, empowering the so-called patients in the process of enabling them to reshape their own lives within their community. Whilst remaining a psychoanalyst, Fachinelli, I claim, was one of the most radical reformers of psychoanalysis.

Elvio Fachinelli was born in 1928 in Luserna (Trentino-Alto Adige), home to the Cimbri ethnic group, whose language, the Cimbro, is a variant of early Germanic or Celtic. ${ }^{2}$ When Fachinelli was a child, his family temporarily moved from Luserna to Melun, near Paris. He therefore had three mother tongues: Cimbro, Italian, and French. His family later returned to Luserna and, after attending a high school in Merano, Fachinelli went to Pavia to study medicine and ended up living in Milan.

The poverty in which the family lived is described by Elvio's brother, as is Elvio's brilliance as a student. He documents Elvio's rise from humble beginnings in an isolated village in an Italian province to become one of the most important Italian psychoanalysts.

When Fachinelli arrived in Milan, he started his analytical training with Musatti (1897-1989), one of the fathers of Italian psychoanalysis and a founding member of the Committee of the Italian Psychoanalytical Society, established in 1935. Fachinelli's analysis with Musatti lasted three years. In Fachinelli's own words:

Probabilmente, con i criteri attuali sarebbe giudicata un'analisi selvaggia come del resto le analisi fatte dalle prime generazioni di psicoanalisti. Eppure secondo me è stata una buona analisi: ho ricevuto sorprese, e questo per me è fondamentale in ogni analisi. Ho imparato e mi sono anche divertito. (Fachinelli 2016, p. 6)

Possibly owing to his brief "wild analysis" ("un'analisi selvaggia”), rather than focusing in the traditional manner on overcoming the resistance of the patient Fachinelli shaped his analytical method around the notion of "welcoming the subject who attends analysis." He thus rethought the analytical setting, accepting that psychoanalysis could be practiced beyond the couch, in public environments, in political and social groups, in 
factories, prisons, slums, and hospitals. Psychoanalysis was rethought as a social practice, rather than as a medical profession.

Fachinelli was, however, also a recognized leading expert on Freud's writings. Musatti entrusted him and his first wife, Herma Trettl, with the translation into Italian of Freud's Traumdeutung in 1966. Fachinelli also translated other works by Freud, including the work on Negation (Verneinung) (Freud 2005).

After Herma Trettl, Fachinelli's long-term companion was Lea Melandri, an important voice of the libertarian and feminist movement. Melandri worked with him during the years of L'erba voglio-1971-1977. L'erba voglio was at the same time a publisher, the name of a journal, ${ }^{3}$ of a kindergarten where innovative anti-authoritarian practices were used, and of a book dedicated to these practices. L'erba voglio therefore constituted a significant part of Fachinelli's social engagement, particularly during the 1970s.

\subsection{The Interweaving of Political, Social, and Personal Contexts in Milan During the 1970s}

Fachinelli lived and worked in Milan, a city which played a central role during the protests of the late 1960s, being a very lively city but also a city laden with social problems. In Milan there was a high density of blue collar workers; there were the most important national newspapers and cultural industries; the theater scene was very lively-Fo at the Palazzina Liberty and Strehler at the Teatro Lirico and Piccolo, to mention just the two most important examples, amongst a myriad of others. The music scene was likewise at a peak-jazz bands such as the Giorgio Gaslini quartet, the almost permanent presence of Gerry Mulligan at the jazz club Capolinea, La Scala for classical music, and folk singers such as Gaber and Jannacci. Milan also hosted a number of political refugees (particularly from Chile and Argentina); was home to a strong student movement; and was the first city in Italy to witness the eruption of feminism and the explosion of selfhelp practices among women.

Besides the left wing protests, however, the 1960s and 1970s also saw the rise of neo-fascist reactionary terrorism. On December 12, 1969, in Piazza Fontana, in the heart of Milan, the first terrorist bomb exploded at the Banca dell'Agricoltura, causing a massacre. With the escalation of violence, the protest movement became more and more fragmented, splitting into a myriad of branches with different ideological orientations. 
From 1973, a branch of the student movement called Gruppo Gramsci started to explore a new way of rethinking Marxism in the light of psychoanalysis. During this period, Madera, Arrighi, and other members of the Gruppo Gramsci decided to abandon political activism. The same happened in 1976 with the most popular group from the extreme left wing, Lotta Continua, a group that held particular fascination for Fachinelli. Within this group of young people, there were many tendencies: from Woodstock and libertarian admirers-who organized the Parco Lambro Festival Re Nudo in Milan-to those who advocated for armed struggle, and eventually joined the terrorist clandestine group Prima Linea. Lotta Continua dissolved at its last congress in Rimini in 1976 (Voli 2006).

At this point, several Marxist militants felt that their political praxis was becoming dogmatic: instead of fighting alienation, Marxism had itself become a kind of social alienation. They also felt that psychoanalysiswith its idea of the infallibility of the analyst - was a form of personal alienation. Many left-wing men, confused by the irruption of feminism into the left-wing movement, consulted Fachinelli and talked to him about their political and personal crises. A new sensibility in which politics was intertwined with the world of intimate feelings was spreading.

A new form of criticism was also arising in many different cultural areas. Left-wing militants started psychoanalytical training, and criticism of the alienating setting of classical psychoanalysis became stronger and stronger. Many psychoanalysts began to change their approach to therapy: group therapy, family therapy, and corporeal therapies, for instance, became relevant approaches to "new" mental disorders, such as anorexia and bulimia.

These two aspects converged in the practice of "wild psychoanalysis" among women without a formal training, which was started, not by chance, by the Milanese women's movement (which included Lia Cigarini, Luisa Muraro, and Lea Melandri). Fachinelli supported their claim that they did not need to be formally analyzed (Madera 2014), and also maintained that male political and personal crises had to be dealt with on a social basis. The issue at stake for Fachinelli was changing society by changing our feelings and views of the society we live in, and doing this through psychoanalysis.

For this to happen, Fachinelli reformed psychoanalysis in two main ways: the first was to broaden its traditional upper-class target (e.g. neurotic patients who talked about their own sexual aversions, obsessions, anguish, manias, or fixations) to a more varied social context in which people could talk about life conditions, salary, politics, religion, work, and 
so on. Far from being a moralist regarding sexuality, Fachinelli considered this in wide terms, shifting from the mainstream psychoanalytical idea of sexual repression to the libertarian movement for sexual liberation, which was coming to the foreground in the cultural climate of the time. More than just criticizing, he was transforming the setting from private to public, and the subject from individual to collective. Differently from the individual subject, the collective subject is asked to deploy an auto-analysis of his or her own practice. Social antagonism is no longer central: the issue at stake is to analyze the preconditions that make the collective into a subject, its perception of being involved in the wider community, and the effects of its actions in social terms. Two such "collective subjects" that reflect on and forge their own analytical path can be found in feminism and democratic psychiatry. Feminism deploys self-help practices, while democratic psychiatry deploys community and systemic therapy, where patients, relatives, psychiatrists, and nurses discuss the rules of domestic partnership together and as equals.

The slogan was: "Il personale è politico" (Voli 2006).

\subsection{Fachinelli, Ferenczi, Lacan}

The second reform of psychoanalysis introduced by Fachinelli was the rehabilitation of Ferenczi's (Dupont 1995; Ferenczi 1994) idea of transference as the core of the therapeutic relationship, replacing the psychoanalytical obsession with resistance with the practice of welcoming, thus proposing the notion of reciprocal analysis. Ferenczi was the first psychoanalyst who dared to talk about this, which inverts the traditional analyst/analysand setting, where the therapist tends to disappear, in favor of an analytical relation composed of two parties.

The most widespread criticism of psychoanalysis focused on the classic setting imposed by the International Psychoanalytical Society (IPS). ${ }^{4}$ Until the 1970s, psychoanalysis was considered the privilege of rich intellectuals. The frequency of meetings between analyst and patient, the use of the couch, the forty-five-minute sessions, the silence of the analyst as the supposed professional position, the enormous amount of money to be paid, the idea of the patient's resistance-and particularly the idea of transference as a subtle resistance-were the benchmarks of psychoanalytical treatment. Freudian psychoanalysis became an institution of power rather than a method for treating mental disorders. 
Some psychoanalysts began to show their discontent with the institutional setting, and when they tried to change the rules of this setting they were isolated, censured, and eventually expelled from the IPS. ${ }^{5}$ Ferenczi's psychoanalysis was starting to be seen as outrageous by the IPS (Barbetta 2015a), precisely because of his notion of reciprocal analysis. His essays (Ferenczi 1994; Dupont 1995) concerning the idea of transference as the core of the psychoanalytical encounter were banned and forgotten, and reciprocal analysis - which Ferenczi considered to be the only way of disentangling the patient from the power of the therapist-became scandalous.

Fachinelli, however, was also critical of Lacan, whose anti-mainstream ideas were being imported into Milan at this time by Verdiglione, Contri, and Drazien. Among other reasons, Fachinelli criticized Lacan for designating the patient with the active term analysant, for which Fachinelli preferred the term "subject who attends the analysis" (soggetto che frequenta l'analisi).

Sciacchitano (2014, pp. 75-76), a Lacanian psychoanalyst who was active in the 1970s and knew Fachinelli well, writes:

Era successo che Lacan si era messo a fare una corte spietata a Fachinelli, perché entrasse nella sua impresa [...]. Nel progetto originario della spaghettipasse Lacan designò tre passeur, scegliendoli tra i propri analizzanti: Muriel Drazien, Giacomo Contri e Armando Verdiglione, un insieme noto tra i lacaniani con il nome collettivo di 'tripode.' Lacan però spasimava per optare come quarto Elvio Fachinelli, forse perché non era uno dei suoi analizzanti (quindi avrebbe potuto dire che non faceva le cose in famiglia) e all'epoca era un bel nome della psicoanalisi. Elvio rispose semplicemente: 'No, grazie.'

Ferenczi and Lacan represent two different developments of Freud's clinical vision. Ferenczi emphasizes transference and countertransference as a practice of welcoming the subject who attends therapy. This involves a rehabilitation of corporeal touch during the session-hugs, caresses, kisses, movements inside the setting, going outside the therapy room-as well as steps towards reciprocal analysis: the possibility for the analyst to disclose their own thoughts, feelings, even dreams. This practice is far removed from Lacan's teachings.

Ferenczi's therapeutic approach focuses mainly on everyday life, its pains and griefs. Lacan instead focuses on the transmission of analysis to the analyst (le désir de l'analyst) (Lacan 1973). Ferenczi's purpose was to take care of his patient's "hidden wounded child" (Ferenczi 1994); 
Lacan's purpose was to shape a new structuralist theory of psychoanalysis, reading Freud in the light of general linguistics. Certainly, Lacan's perspective is more endearing and enchanting from a literary point of view. Nevertheless, Fachinelli was more involved in changing the clinical practice of psychoanalysis.

Fachinelli engaged directly with Lacan's teaching. The final part of his last book (Fachinelli 1989), "Lacan and the Thing," is dedicated to criticizing Lacan's linguistic reading of the unconscious. In brief, according to Lacan the unconscious is structured like a language and psychosis is a "hole" in language, in the very structure of the unconscious. It is as if one were unable to accede to something that is proper to oneself, which Lacan calls "The-Name-of-The-Father" and which is the very foundation of the Symbolic Order. According to Fachinelli, Lacan ultimately wants to read the taboo of incest-the Oedipal Triangle-in terms of linguistic structure. This, in Fachinelli's view, cannot work:

Se tra la Cosa e il soggetto si alza la barriera dell'incesto, allora ogni avvicinamento a essa acquista il significato della trasgressione della legge $[\ldots] \mathrm{e}$ allora eccoci davanti alla psicosi. Sono le conclusioni di Lacan. Se invece la Cosa è caratterizzata come madre primordiale divenuta 'vuoto centrale,' irraggiungibile di per sé, allora il rapporto può avere il senso di un movimento asintotico verso di essa, non interrotto, nel suo procedere, da ostacoli o preclusioni (forclosures) esterne e soprattutto non connotato esclusivamente in senso patologico. (Fachinelli 1998, p. 193)

In concluding a conference in Milan in 1974, Lacan asks Fachinelli, who was present, to help him:

Lacan: Ah, Fachinelli, mi dimostri che ha capito qualcosa...

Fachinelli: Voglio porle una domanda...

Lacan: Cioè? È tutto quel che chiedo...

Fachinelli: Si tratta anche di una famosa disputa...

Lacan: Dica, mio caro....allora...

Fachinelli: L'ho già fatto. [Ha compinto il gesto di passare il dorso delle dita sotto il mento]. (Contri 1978, p. 138)

Fachinelli's response is a typical Neapolitan gesture that means "I don't care." He was reproducing an exchange that took place between Sraffa, an Italian economist working in Cambridge, and Wittgenstein. Sraffa once told Wittgenstein that after he had read the Tractatus Logico-Philosophicus, 
his objection to Wittgenstein's work could be expressed in the gesture of passing the back of his fingers under the chin.

Fachinelli argues that such gestures belong to a corporeal language-in this case not Italian but Neapolitan-that emerges within a cultural framework and a corporeal context. Lacan's opinion, expressed in the continuation of this conversation, is that body language "sta dal lato dell'ostacolo. Il che fa sì che uno dei più grandi ostacoli all'amore sia proprio il corpo" (Lacan in Contri 1978, p. 139).

On the contrary, according to Fachinelli (in Contri 1978, p. 139), the body is not an obstacle: "vi è un simbolico, una lingua del corpo [...] l'ostacolo, insomma, la lingua che parla è ben quella del corpo." Fachinelli's criticism of Lacanian psychoanalysis refers to the use during the session only of verbal language, in a kind of language game (à la Wittgenstein) in which the body does not matter.

The Lacanian cut, interrupting the session on a particular word spoken by the analysant, expresses a kind of "artificial inversion" in which language itself is supposed to be "the subject who talks" (ça parle). The analyst has the power to sever the conversation on a particular word or locution when such a word or locution is regarded as the metonymy, or metaphor, of the analysant's symptom.

\subsection{Fachinelli's Passion for Freud}

Somewhat ironically, we could compare the continuity between Freud and Lacan with the continuity conceived by the Catholic Church between the Old and the New Testament, a continuity endorsed only by the supporters of the New Testament, but not recognized by those who belong to the Jewish tradition. This issue was raised more particularly by Meghnagi, a Jewish psychoanalyst with whom Fachinelli interacted during the last years of his life:" "Meghnagi ci ha detto che in fondo la psicoanalisi è la battuta di spirito di un ebreo nei confronti della società occidentale" (Fachinelli 2012, p. 109).

Fachinelli always declared his loyalty to Freud's texts, although he did not consider them as a consistent doctrinal corpus, but as a panoply of different fragments (clinical, literary, philosophical, neurological, etc.). According to Fachinelli, this panoply is not a philosophical system but contains contradictory ideas, stratified according to Freud's life history. From Fachinelli's point of view, Freudian thought must be considered as a melting pot of observations that trace a fragmentary path towards 
singularity, marginality, and idiosyncrasy. In The Interpretation of Dreams, Freud writes:

We have given equal attention, in the interpretation of dreams, to every nuance of verbal expression found in them; indeed, whenever we were confronted by a senseless or insufficient wording, as though we had failed to translate the dream into the proper version, we have respected even these defects of expression. In brief, what other writers have regarded as arbitrary improvisations, concocted hastily to avoid confusion, we have treated like a sacred text. (Freud 1997, p. 357)

The concept of "sacred text" for Freud seems to refer to a process of reading according to the Jewish tradition. It is worth recalling at this point that Fachinelli, together with his first wife Herma Trettl, translated The Interpretation of Dreams into Italian, this being a text that arguably presents an alternative approach to psychoanalysis, being rather different from, if not in opposition to, mainstream psychoanalytical trends:

Thus I perceive the nature of the relation between the dream-content and dream-thoughts: Not only are the elements of the dream determined several times over by the dream-thoughts, but the individual dream-thoughts are represented in the dream by several elements. Starting from a content of the dream, the path of the association leads to a number of dream-thoughts; and from a single dream-thought to several elements of the dream. (Freud 1997, p. 175)

Treating the dream as a "sacred text" should mean neither revealing dogmas coming from a transcendent project of salvation, as in the Christian tradition, nor revealing hidden symptoms; it is rather a never-ending investigation with a plurality of meanings. The way a dream is recounted, depending on how it is phrased, can completely change the meaning of the dream. According to Freud, psychoanalysis is neither about the length of the therapeutic process nor the intensity of the encounters; it is about a "never-ending analysis" (Freud 1999a). In the Freudian palimpsest, it is quite clear that the above quotation contradicts the central statement of psychoanalysis "Wo Es war, soll Ich werden," when this is translated as "Where Id was, there Ego shall be" (Freud 1979, p. 112; see also Lavagetto 1997). The notion of the Ego, as a stable instance of selfcontrol, has nothing to do with the genuine psychoanalytical tradition; it is rather an attempt of mainstream psychoanalysis to be recognized by the 
psychiatric institutions of the 1950s and 1960s, dominated as they were by what has been called Ego-Psychology.

However, if the statement "Wo Es war, soll Ich werden" is translated as "Where it was, I shall become," the psychoanalytic panorama changes completely. This second translation appealed to those psychoanalysts who, during the 1970s and 1980s in Italy, were influenced by what orthodox Freudians derogatorily termed "wild psychoanalysis," which was the outcome of a libertarian influence on psychoanalysis.

The second translation is also the one Lacan accepted, thus arguably confirming that the influence of Lacanianism on new trends in psychoanalysis from the 1970s to the present is strong. However, the social and political roots of Lacan's and Fachinelli's psychoanalyses are rather different. Since Fachinelli was a libertarian Marxist, his main interest was far from putting the patient on the couch; he was engaged in applying psychoanalysis within the social environment, dealing with the working class, with salary, poverty, and unemployment, prisons and institutional violence, schools and authoritarianism, madness and psychiatric power.

As a matter of fact, the translation "Where it was, I shall become" relocates the psychoanalytical interest from Being (Ego shall be) to Becoming (I shall become); from the alienating status of the Ego, cured by the knowledge/power of the analyst (Human Being), to the subjectivation of those who "attend analysis" (Human Becoming).

\subsection{Reciprocity and Social Criticism}

To sum up, there were two main influences on Fachinelli's ideas and practices: the first is Ferenczi's criticism of the Freudian idea that transference is a kind of resistance, which prompted Ferenczi to propose that transference should be turned into the core of therapy; and Ferenczi's proposal of reciprocal analysis, where patient and analyst freely exchange their roles, which Fachinelli embraced in the wake of post-1968 criticism of psychoanalysis. In 1975, during a conference entitled Sexuality and Politics (Fachinelli 1975), Fachinelli gave a talk entitled "Il denaro dello psicoanalista." During the talk, Fachinelli proposed a correspondence between psychoanalysis and prostitution; in both cases the client pays (works) for the provision of a service (sexuality):

Nell'analisi, qualcuno, l'analista, offre a pagamento una prestazione, un servizio, un'assistenza, chiamatelo come volete, qualcosa che nella sostanza è 
dell'ordine del lavoro, mentre qualcun altro, l'analizzando, chiede contro denaro qualcosa che è sempre dell'ordine di eros e della sua storia. (Fachinelli 1975, p. 311)

At first glance, the "contract" established between patient and analyst is an exchange: the analysis of incestuous desire in exchange for a salary. This situation recalls Hegel's dialectic of the Master/Slave, where alienation is not just the process of exploitation of the Slave by the Master, but rather a reciprocal experience of alienation. In fact, classic analysis has one more trick up its sleeve: The Master - the one who pays the money-is the Patient, and the Slave - the one who is supposed to possess the knowledge-is the Analyst. At first glance, it seems that the alienated part of the therapeutic process is the analyst, the subject supposed to know. It is, in fact, the other way around.

The question posed by Fachinelli is why, during classic analysis, the money issue is discussed as "economic condition" only at the outset of an ongoing process, while during the following sessions everything is related back to Oedipal sexuality, which is considered the basis of the symptom. So, during this kind of analytical process, paradoxically, alienation is discussed only inasmuch as it relates to topics "allowed" during the talking cure. It seems that the Master (the analysand) is giving a salary to the Servant (the analyst) for her/his own "profit." But the one who becomes economically richer during this process is the Servant not the Master. This is the trick unveiled by Fachinelli: a double-sided alienation, as in the joke "heads I win, tails you lose" (Freud 1999b, p. 257).

The social status of the client is only mentioned at the beginning as part of a contract that cannot be discussed during the course of the treatment. With regard to politics, it is of no importance whether the client is democratic or totalitarian in outlook, as if totalitarianism would not be a socially dangerous ideology that should be fought; similarly, with regard to religion, the analyst has no interest in whether the client is a fundamentalist or an atheist, for instance-these matters are never raised; with regard to work, factory workers, peasants, and unemployed people are excluded for financial reasons; art is simply a sublimation of psychic symptoms; marriage is something to be "saved" or, if the patient is single, a "happy ending" to aim for, where gender orientation is relevant/discussed only if the patient is homosexual, in which case this "condition" is symptomatic. Friendship is a forbidden topic, because it could involve friendship between the analyst and client, which is considered dangerous; other everyday life issues are considered to be mere epiphenomena of Oedipal symptomatology. 
Supposed "Ego strength," in this version of psychoanalysis, involves the maturation of a self-controlled sexuality, with no regard for other areas of social interaction. The mature individual who emerges from such a process is, in the male version, the professional breadwinner who runs a functional family; in the female version, the professional home-maker who raises children and possibly gets a part-time job, frequents charity groups, or goes to women's institutes.

Fachinelli is concerned with how to transform this reciprocal alienation, concealed within the asymmetrical relationship between analyst and analysand/analysant, into a different and more welcoming reciprocity. It is quite clear that Fachinelli's point of view involves a kind of social deconstruction of the psychoanalytical setting. Psychoanalysis must be liberated from a rigorous and obsessive setting, and the patient freed from the couch, so that the roles of the two parties are transformed from asymmetry to reciprocity.

\subsection{L'ERBA VOGLIO: SOCIAL Psychoanalysis}

During the 1970s, Fachinelli published-together with feminist pedagogues and teachers - a cultural review and a book both entitled L'erba voglio (Fachinelli et al. 1971). ${ }^{7}$ The book traces the history of a libertarian kindergarten opened in Milan Porta Ticinese (a working-class area) with the idea of freeing children from an authoritarian process of education that transmitted upper-class ideals. L'erba voglio also published a number of books, including L'uomo col magnetofono (Abrahams 1977, see also Conserva et al. 2017) in 1977.

This was published together with the comments that Sartre, Pontalis, and Pingaud made after it had been published in France by the journal Les Temps Modernes in 1969 (Abrahams et al. 1969). To these, Fachinelli added his own comments. L'uomo col magnetofono was born from a reallife event. Jean-Jacques Abrahams, a young Jewish patient, wanted to force his analyst to explain all the jargon and the "techniques" used during the very long and intense period of analysis. He carried a magnetophone, an audio recording device, into the analytical session. The psychoanalyst refused to talk into the recorder, so the young patient took him hostage in the studio for the whole duration of the session.

After this event, Abrahams was sent to a mental asylum, but fled by rappelling down from the third floor of the hospital using the bedsheets, and broke one of his hands in the process. Eventually, Abrahams sent the recorded tape to Sartre, who wrote it down and published it in Les Temps 
Modernes. L'homme au magnetophone is a theatrical play, although it is also the record of the argument that the author had with his psychoanalyst, Dr. Van Nypelseer.

The text may be understood in different ways:

- An unreasonable harassment, rather than a rebellion, that degenerated into the forcible confinement of the psychoanalyst, which was carried out by Abrahams himself in Dr. Van Nypelseer's studio;

- The forceful rebellion of a patient against a psychoanalyst, after many years of obsessive/paranoid treatment;

- An attempt to readjust a strongly asymmetrical doctor/patient relationship using the "democratic" magnetophone, so as to call others to witness what happens in the professionally secret sanctum of the analyst.

The conversation is a crescendo of altercation, and the text makes it clear that a physical fight is taking place. Abrahams blocks the door of the analyst's studio, preventing the doctor from leaving. While reading the pages that detail this quarrel, one might, on the one hand, side with the doctor-in which case one will feel increasing anxiety; or one might side with the patient-in which case one will probably feel an aggressive thirst for revenge.

The Italian translation published by L'erba voglio (1977) includes as a postscript the argument between Sartre, who published the text in 1969, and Pontalis and Pingaud, who were against its publication. The Italian edition also includes a thirteen-page commentary written by Fachinelli (in Abrahams et al. 1977). Says Fachinelli:

Ora, se qualcuno-dopo aver rotto col suo analista, essere stato ricoverato con la violenza in ospedale psichiatrico una settimana dopo, esserne evaso rompendosi una mano-se qualcuno se ne viene fuori con un testo di questa forza, che spedisce alla persona giusta, in grado di pubblicarlo, ebbene bisogna pur ammettere che in questa persona è avvenuto uno scatto, una invenzione nella realtà che dovrebbe porre seri interrogativi a un analista. (Fachinelli in Abrahams et al. 1977, p. 59)

And further on:

Il senso più urgente di questa 'scatola nera' piombata nella 'caverna' dell'analista è precisamente la sua capacità tecnologica di afferrare e ricreare- 
come l'attività teatrale, e forse meno ambiguamente - una (parziale) presenza fisica delle persone assenti. (Fachinelli in Abrahams et al. 1977, p. 65)

Fachinelli views the magnetophone as a technological device that potentially imposes democracy on the asymmetrical setting of analysis. It is clear that the theatrical performance acts out a violent redemption of the patient from an orthodox psychoanalyst, who is also an orthodox psychiatrist and who has the power to hospitalize the "patient" as part of psychoanalytical treatment. The magnetophone plays a role in unveiling the hidden violence beneath conformist and orthodox analytical methods.

\subsection{Psychoanalysis as a Modern Practice}

In the 1980s, Fachinelli developed a psychoanalytical framework based on new key concepts, such as "claustrophilia" and "ecstatic mind" (Fachinelli 1989). In Claustrofilia, Fachinelli returns to some of the issues raised in his 1975 presentation "Il denaro dello psicoanalista," developing a more sophisticated criticism of the classic psychoanalytical setting, with an analysis of the terms onorario (fee) and salario (salary). The word onorario is envisaged, according to traditional use, as a una tantum sum, paid by the person receiving a service to the practitioner who "honors" the commitment. "Salary" (which derives from the allowance of salt paid to soldiers during the Roman Empire) is a fixed amount of money paid to workers in the modern machine-age society:

Con l'introduzione su larga scala delle prime generazioni di macchine, le 'mansioni' dell'operaio addetto si modificarono rispetto all'attuazione di un compito preciso ben definito. Si spostarono verso la sorveglianza del lavoro fatto dalle machine, che a sua volta era ripetitivo, sempre uguale, con pochi 'tempi morti' e così via. Ora, è del tutto notevole che Freud, passando al tipo definitivo di psicoterapia, sia andato incontro, senza esserne consapevole, a modificazioni analoghe della sua attività $[\ldots]$ In questo senso l'attività psicoterapeutica $[\ldots]$ diventa, per la prima volta nella storia, un lavoro proto-industriale, dove il 'lavoro' è formalmente separato dalla 'vita,' ma dove la 'vita' è inglobata dal 'lavoro' [...] la costanza del tempo macchinico si riflette in una durata programmaticamente indefinita del 'trattamento.' Eliminando i 'tempi morti,' viene eliminata tendenzialmente anche la morte. (Fachinelli 1998, pp. 24-25) 
Fachinelli's premature death in 1989, aged sixty, at the peak of his career, prevented him from establishing a school of psychoanalysis. Nevertheless, he left a legacy for the next generation of psychotherapists: how to deal with dis-alienating practices. Far from considering so-called mental disorder as a mere neurological issue, or as an intimate issue related to the Oedipal Triangle, he transmitted to us the necessity to work within the social field and cultural climate as a way of discovering a never-ending process of developing psychotherapy in connection with the zeitgeist of the present.

His ideas were uncomfortable for mainstream psychoanalysis of his time. To some extent he was on his own, and it was easy, during the massive transformation of the Italian zeitgeist between the Sixties and the Seventies, for others to amend his thought, concealing the social aspect of his practice, denying the social criticism implied in his contribution to psychotherapy. If we exclude the publication by Adelphi of Fachinelli's work and the book written in 1998 by Benvenuto, who insists on the joyfulness of Fachinelli's practice, nothing particularly important happened until the last five years.

The irony Fachinelli directed towards Freudian official psychoanalysis and his critique of the new wave of linguistic Lacanian "transmission" of psychoanalysis have evidently been rejected or ignored by the Freudian and Lacanian orthodoxies. Nevertheless, these criticisms must not be confused with those advanced by the enemies of psychoanalysis. Both are a consequence of Fachinelli's heretical, and anti-orthodox, spirit. They must be considered as an effort to change the practice of psychoanalysis, as well as other new practices in psychotherapy that were implemented in Milan during the 1970s, such as the Milanese school of systemic therapy (Selvini et al. 1985; Barbetta 2017).

Fachinelli was truly rediscovered twenty years after his death. Italian psychoanalysis has finally begun to appreciate his importance as a clinician and social philosopher (Melandri 2014; Fachinelli 2016). Fachinelli was a brilliant scholar, although he did not come from a rich and culturally sophisticated environment. This was pivotal in making him take the heretical position of refusing to belong to any specific family or branch of psychotherapy. 


\section{Notes}

1. I refer here to Lacan's notion of "subject supposed to know:" "The term 'subject supposed to know' does not designate the analyst himself, but a function which the analyst may come to embody in the treatment. It is only when the analyst is perceived by the analysand to embody this function that the transference can be said to be established. When this occurs, what kind of knowledge is it that the analyst is presumed to possess? [...] The analyst is often thought to know the secret meaning of the analysand's words, the significations of speech of which even the speaker is unaware." (Evans 1996, p. 199).

2. Although many Italian scholars are currently studying Fachinelli's activity as a psychoanalyst and political militant (among them see Fachinelli 2016; Benvenuto 1998; Melandri 2014; Madera 2014; Sciacchitano 2014; Janigro 2014; Dotti 2016; Barbetta 2013, 2015b), an exhaustive biography of Fachinelli has not yet been published. Giuditta Fachinelli, Elvio's daughter and curator of her father's archive, has provided some unpublished conversations, including one with Elvio's brother.

3. Now digitized at: https://www.inventati.org/apm/archivio/320/ERB/ lerbavoglio.php.

4. For an introduction to the official rules of the psychoanalytic setting see the official IPA website at http://www.ipa.world/en/Psychoanalytic Treatment/About_Psychoanalysis.aspx, accessed on August 8, 2018.

5. It happened among others to Ferenczi himself, whose Clinical Diary remained for years untranslated into English; to Melanie Klein, whose work with children put her at risk of being expelled from the Psychoanalytical Society (Kristeva 2001); to Wilhelm Reich who was expelled for being a Marxist; and to Jacques Lacan for changing the length of the session. See for instance Steiner (2011).

6. See Fachinelli (2012) and Meghnagi (2004).

7. The name L'erba voglio comes from an Italian proverb: "L'erba voglio non cresce neppure nel giardino del Re" ("Not even in the King's garden does the 'I want' herb grow"). The idea that l'erba voglio might actually exist and grow somewhere seems to go beyond the concept of Nature as an unkind mother that limits your desires and to foster a libertarian concept of unfettered development of human faculties, regardless of rank, status, or social, cultural, and economic position.

\section{REFERENCES}

Abrahams, Jean-Jacques, et al. 1969. L'Homme au magnétophone. Les Temps modernes, 274.

- 1977. L'uomo colmagnetofono. Trans. Elvio Fachinelli. Milan: L'erba voglio. 
Barbetta, Pietro. 2013. Il Freud di Fachinelli. TYsm, Literary Review 1 (2). http://tysm.org/il-freud-di-fachinelli/. Accessed 3 Aug 2018.

- 2015a. The Outrageous Discourse of Psychoanalysis for Present Day Academic Institution. Open Journal of Social Sciences 3 (3): 133-138.

- 2015b. Elvio Fachinelli, il clinico che ridefinì l'osceno. http://www.doppiozero.com/rubriche/336/201508/elvio-fachinelli-il-clinico-che-ridefinilosceno. Accessed 3 Aug 2018.

- 2017. Milan Systemic Family Therapy. In Encyclopaedia of Couple and Family Therapy, ed. Jay Lebow, et al. New York: Springer International Publishing. https://www.springer.com/la/book/9783319494234. Accessed 3 Aug 2018.

Benvenuto, Sergio. 1998. La "gioia eccessiva" di Elvio Fachinelli. In Elvio Fachinelli, intorno al '68: Un'antologia di testi, ed. Marco Conci and Francesco Marchioro, 249-278. Rome: Massari Editori.

Conserva, Giacomo, Pietro Barbetta, and Enrico Valtellina, eds. 2017. Un singolare gatto selvatico: Jean-Jacques Abrahams, l'uomo col magnetofono. Milan: Ombre Corte.

Contri, Giacomo, ed. 1978. Lacan in Italia 1953-1978. Milan: La Salamandra.

Dotti, Marco. 2016. Non si ridicolizza il reale: La lezione di Elvio Fachinelli. Vita. http://www.vita.it/it/article/2016/03/06/non-si-ridicolizza-il-reale-lalezione-di-elvio-fachinelli/138535/. Accessed 3 Aug 2018.

Dupont, Judith, ed. 1995. The Clinical Diary of Sandor Ferenczi. Cambridge, MA: Harvard University Press.

Evans, Dylan. 1996. An Introductory Dictionary of Lacanian Psychoanalysis, London Routledge.

Fachinelli, Elvio. 1975. Il denaro dello psicoanalista. In Psicoanalisi e sessualità, ed. Armando Verdiglione, 308-315. Milan: Feltrinelli.

- 1977. La parola contaminata. In Abrahams, Jean-Jacques et al. L'uomo col magnetofono, Milan: L’erba voglio.

- 1989. La mente estatica. Milan: Adelphi.

- 1998. Claustrofilia. Milan: Adelphi.

- 2012. Su Freud. Milan: Adelphi.

- 2016. Al cuore delle cose: Scritti politici (1967-1989), ed. Dario Borso. Roma: Derive e approdi.

Fachinelli, Elvio, et al. 1971. L'erba voglio. Turin: Einaudi.

Ferenczi, Sandor. 1994. Confusion of Tongues Between Adults and the Child. In Ferenczi, Sandor. Final Contributions, 156-167. London: Hogarth.

Freud, Sigmund. 1979. An Outline of Psychoanalysis. London: Hogarth Press. 1997 (1899). The Interpretation of Dreams. Ware: Wordsworth. 1999a. Analysis Terminable and Interminable. In The Standard Edition of the Complete Psychological Works of Sigmund Freud, ed. James Strachey. 24 volumes. New York: Vintage. 
1999b. Construction in Analysis. In The Standard Edition of the Complete Psychological Works of Sigmund Freud, ed. James Strachey. 24 volumes. New York: Vintage.

- 2005. The Unconscious. London: Penguin.

Janigro, Nicole. 2014. La stanza d'analisi tra cielo e terra. In L'attualità inattuale di Elvio Fachinelli, ed. Lea Melandri, 49-57. Milan: IPOC.

Kristeva, Julia. 2001. Melanie Klein. New York: Columbia University Press.

Lacan, Jacques. 1973. Le Séminaire, Livre XI: Les quatre concepts fondamentaux de la psychanalyse. Paris: Seuil.

Lavagetto, Mario. 1997. Palinsesti freudiani, Arte Letteratura e linguaggio nei Verbali della Società psicoanalitica di Vienna 1906-1918, Torino: Bollati Boringhieri.

Madera, Romano. 2014. Chissà dove, chissà quando. In L'attualità inattuale di Elvio Fachinelli, ed. Lea Melandri, 69-72. Milan: IPOC.

Meghnagi, David. 2004. Il padre e la legge: Freud e l'ebraismo. Venice: Marsilio.

Melandri, Lea, ed. 2014. L'attualità inattuale di Elvio Fachinelli. Milan: IPOC.

Sciacchitano, Antonello. 2014. La psicoanalisi chiede asilo. In L'attualità inattuale di Elvio Fachinelli, ed. Lea Melandri, 73-87. Milan: IPOC.

Selvini, Palazzoli Mara, et al. 1985. Paradox and Counterparadox. Lanham: Aronson.

Steiner, Riccardo. 2011. In All Questions, My Interest Is Not in the Individual People but in the Analytic Movement as a Whole. It Will Be Hard Enough Here in Europe in the Times to Come to Keep It Going. After All We Are Just a Handful of People Who Really Have That in Mind.... The International Journal of Psychoanalysis 92 (3): 505-591.

Voli, Stefania. 2006. Quando il privato diventa politico: Lotta Continua (1968-1976). Rome: Edizioni Associate. 


\title{
From the Factory to the Asylum... and Back: A Lacanian Perspective on the Cinematic Representation of Alienation in Elio Petri's La classe operaia va in paradiso
}

\author{
Luca Di Gregorio
}

One has to admit that there is a lot of this alienation about nowadays. Whatever one does, one is always a bit more alienated, whether in economics, politics, psycho-pathology, aesthetics, and so on. It may be no bad thing to see what the root of this celebrated alienation really is. May 27, 1964. Lacan $(1998$, p. 210)

\subsection{The Alienation of the Working Class Between Subjectivity and Social Reality}

Cinematic representations of alienation in factories or asylums are not common in Italian films from the 1950s and 1960s, contrarily to Italian literary works of the same period (Rigola 2015). However, during the

\footnotetext{
L. Di Gregorio (欧)

University of Winchester, Winchester, UK

University of Southampton, Southampton, UK

e-mail: Luca.DiGregorio@winchester.ac.uk

(C) The Author(s) 2019

A. Diazzi, A. S. Tarabochia (eds.), The Years of Alienation in Italy, https://doi.org/10.1007/978-3-030-15150-8_9
} 
1970s, a decade of intense economic, social, and industrial transformations, Italian cinema shifted its focus onto sociopolitical issues, addressing and documenting previously unrepresented realities, such as those of factory workers and asylum inmates (Uva 2015; Lombardi and Uva 2016). La classe operaia va in paradiso (Petri 1971), aka Lulù the Tool, is one of the first mainstream films in postwar Italian cinema to focus on controversial issues that had previously been systematically overlooked by Italian cinema (Spagnoletti 2012, p. 67), such as class conflict, the workermachine relationship, and the impact of factory work on mental health (Miccichè 1980; Mondella 2012; Williams 2013; Rigola 2015). ${ }^{1}$ More importantly, this film revolves entirely around those Foucauldian spaces, namely the factory and the asylum, which epitomize the very notion of alienation.

The film focuses on the "figura alienata del protagonista" (Spagnoletti 2012, p. 69), Ludovico Massa (Gian Maria Volonté), nicknamed Lulù, a piece worker in his early thirties employed at the BAN factory, ${ }^{2}$ who suffers a mental breakdown and forms a friendship with a former colleague confined in an asylum. The film depicts Lulù's alienation, caused by factory overwork, and its impact on his self-perception and interpersonal relations, showing "how values and mentality, including sexuality, are structured by factory discipline, work habits and consumerism" (Portis 2010b, p. 46). In so doing, the film addresses both the social (the working-class struggle in Italian capitalist society during the early 1970s) and the individual (the protagonist's mental breakdown) dimensions of alienation. As such, the film combines, on the one hand, "social criticism and political commitment" and, on the other, an "exploration of existential subjectivities" (Portis 2010a, p. 18), ${ }^{3}$ which results in a unique portrait of the "class struggle in the singular" (Williams 2013, p. 53). Petri focuses on the vicissitudes of the protagonist (Rugo 2015, p. 106) to challenge the perception of the working class as an anonymous entity, which was particularly common in the leftist political discourse of the period (Portis 2010b, p. 47). At the same time, however, Petri succeeds in rendering the figure of the protagonist relatable and universal, representing alienation as a widespread condition in contemporary Western capitalist society. As Petri (quoted in Portis 2010 b, p. 46) puts it, "the workers are the first victims, but $[\ldots]$ anyone who works in the capitalist system, based on the need to produce as much as possible, suffers from the same tensions, from the same alienation."

In this chapter, I will contend that, more effectively than Marxist and Freudian theory, Lacanian theory makes it possible to tackle this twofold dimension of alienation portrayed in Petri's film as both a fundamental 
condition of human subjectivity and a sociohistorical manifestation of capitalism. By furthering Marx's conception of alienation as something contingent upon a specific socioeconomic system (Musto 2010, p. 82) and by expanding upon Freud's notion of the unconscious as something transindividual and historically determined (Dean 2000; McGowan 2004, 2016), Lacan establishes a connection between the fundamental alienation of the subject and the peculiar sociohistorical form of alienation that characterizes contemporary Western society (Tomšič and Zevnik 2015, p. 3), ultimately bringing together subjectivity and social reality. Drawing from Lacan, I also argue that the political kernel of Petri's film rests not simply on the representation of class struggle (Portis 2010a, b; Spagnoletti 2012; Williams 2013), but rather on a conception of alienation as a possible force of transformation. As Tomšič (2015a, p. 10) puts it, Lacan's notion of alienation "also appears as constitutive of the subject and of society, a process that no longer stands merely for deprivation but also and above all for transformation." For Lacan, alienation is indeed only conceivable as something coupled with "separation" (from the Other in which the subject is alienated) and, therefore, it is not the "unsurpassable horizon of our existence" (Žižek 2017, p. 455). Petri's film, however, ends with the protagonist's hopeless return to the assembly line, which signals his failure to become a subject, namely to be separated from the Other qua factory and, ultimately, from the capitalist mode of production.

\section{2 “L'individuo è UGUALE ALLA FABBRica!"}

Petri's film depicts Marx's conception of alienation (Brunetta 2009, p. 234; Portis 2010 b, p. 43 ) by portraying the protagonist as an "utterly dehumanized and subjugated individual" (Vighi 2006, p. 100) who has devoted his life to the BAN factory. Through the technique of the closeup, Petri's "cinematic trademark" (Antonello 2016, p. 296), and by means of a "caricatural and slightly hysterical style" (Moliterno 2008, p. 249), in several scenes Lulù is represented working frantically and obsessively at the machine to increase the factory's productivity. According to Marx, " $t]$ he alienation of the worker in his product means not only that his labor becomes an object, an external existence, but that it exists outside him, independently, as something alien to him, and that it becomes a power on its own confronting him" (1988, p. 72; original emphasis).

Following Marx's classical conception of alienation (Entäusserung), the factory is not merely depicted as a physical space where workers carry out 
their duties, but rather as a mental space from which the protagonist cannot escape, or better still as a state of mind that has already pervaded the protagonist's life, marking his everyday routine and, ultimately, upsetting his entire existence. For instance, the factory makes its first appearance in the film by means of auditory and visual elements that upsettingly disrupt Lulù's sleep. Indeed, the film begins with a sinister noise that resembles that of factory machines and soon fades into the ticking of an alarm clock in the bedroom where Lulù and his partner Lidia (Mariangela Melato) are sleeping. Immediately after that, a disquieting series of letters, which form the factory's name, disturb Lulù during the night, making him feel completely helpless and trapped in a meaningless routine upon awakening the following morning.

Interestingly, at the same time as the release of the film, Lacan's teaching was characterized by a "systematic reference to Marx" (Tomšic 2015b, p. 151) ${ }^{5}$ which culminates in the notion of the discourse of the Capitalist. ${ }^{6}$ Bluntly put, Lacan suggests that since the 1970s we have entered a new historical constellation characterized by radical psychosocial transformations. He contends that Freud's social theory, according to which human society is built upon the imperative to sacrifice individual enjoyment for the greater good, is no longer valid (Contri 1978; Lacan 2007a, b). Lacan maintains instead that it is the discursive regime of the capitalist that permeates society today, fostering the superegoic injunction to "enjoy!" in relation to potentially unlimited object consumption (Lacan 1960, 1990). In the discourse of the capitalist, every commodity appears as a remedy that promises to fill the lack inherent in human nature, thus promoting a notion of subjectivity as a field totalized by its production and consumption of economic value and, ultimately, fostering the idea of self-realization beyond limits (Lacan 2017).

This is evident in the first part of the film, when the protagonist is portrayed as "il perfetto prototipo dell'uomo colonizzato dal capitalismo" (Spagnoletti 2012, p. 69). Lulù behaves selfishly and is particularly interested in earning more money to buy material goods for himself and his family, exemplifying "the bodily and psychological register of a specific moment in Italian capitalism" (Williams 2013, p. 56). From this perspective, the film "laid bare the psychic troubles affecting working-class consciousness, caused by alienated work and consumerism" (Portis 2010b, p. 48). During a protest, one of the students affirms: "il proletario medio è sfruttato in fabbrica però si modella sugli esempi che gli vengono dati dalla televisione, dai quotidiani, dai rotocalchi, dal cinema. Vive da povero, 
da miserabile, però imitando sempre il suo sfruttatore." According to Lacan (2017), the discourse of the capitalist undermines social bonds, dismisses the idea of love, and promotes an extreme individualization that results in a "radical shift in social relations" (Sforza Tarabochia 2016, p. 8). As others have already noted (Rossi 1979; Williams 2013), the protagonist's surname, Massa, might refer to the mass factory worker, thus becoming the "simbolo di un uomo massificato, segno di carne di un'impossibilità all'aggregazione, alla riunione in chiave rivoluzionaria" (Spagnoletti 2012, p. 69). At the beginning of the film, Lulù is completely uninterested in politics, the worker-student movement, or workers' rights. $\mathrm{He}$ is also unable to develop meaningful relationships with his fellow workers, whom he blames for not being sufficiently productive, with his partner Lidia or with his lover Adalgisa, a factory worker with whom he has casual sex on one occasion. After they engage in sexual intercourse in Lulù's car, Adalgisa (Mietta Albertini) wonders "ma è amore questo qua?," to which the protagonist bluntly replies "amore, amore... amore si fa e quando è fatto è fatto e uno ritorna in sé," to which she comments, sadly, "Già, come le bestie..."

From the beginning of the film, the protagonist is aware of his miserable condition as an exploited factory worker, performing an unskilled and repetitive job. For example, in one of his rants, he shouts "l'individuo è uguale alla fabbrica. Fabbrica di merda!" or, later on in a public debate with other factory workers, "noi siamo come le macchine: io sono un bullone, io sono una vite, io sono una cinta di trasmissione, io sono una pompa." Nevertheless, Lulù appears to be subjugated to the capitalist superego and its unsatisfiable imperative to "produce." Lulù behaves like an exemplary Stakhanovite worker, centering his life on "hyperproductivity on the assembly line" (Bondanella 2009, p. 244) and succeeds in becoming a record champion of piecework. Lulù's obsession with productivity ensures that he maintains a frantic pace of work, which makes him particularly appreciated by the foremen and factory managers but strongly disliked by his fellow workers. When one of his colleagues comments "senti Lulù, te non muori mica nel tuo letto sai, te muori qua, sulla macchina," Lulù immediately answers "indifferente! [...] io c'ho la forza lavoro, solo quello." In capitalism, "everyone is 'translatable' into labour-power, a quantifiable subjectivity" (Tomšič 2015b, p. 152). Labour power is the only value Lulù thinks he possesses, to the extent that he becomes a mere commodity in the factory. As the American release title highlights, the protagonist is literally reduced to nothing more than one factory tool amongst others. 
At this point, it is time to raise what I consider to be the crucial question presented by the film: why is Lulù so devoted to the factory and to the (unsustainable) capitalistic mode of production, despite being fully aware that he is being exploited and that his physical condition is deteriorating? A Marxist perspective seems insufficient to address this paradox, which rests on the "painful pleasure and pleasurable pain" (Evans 1998, p. 14) Lulù seems to feel when working at the machine. This paradox takes place not despite of, but rather because of, the painful/pleasurable excess Lulù experiences through his work at the factory, which is strongly connected with his libidinal economy. As opposed to Marx, Lacan "proposes a more complex reading of the relation between the social structures (institutions such as law, family, church, etc.), the subject of the unconscious, and the libidinal economy" (Tomšič and Zevnik 2015, p. 3). From a Lacanian perspective, the paradox of Lulù's attachment to his exploiting work at the factory rests on his libidinal attachment to his alienation, which "prevents [him] from fully subjectivizing the absurdity of his condition" (Vighi 2016a, p. 75).

The first scene shot in the factory clearly shows that this libidinal attachment is conveyed and encouraged by the factory. Every working day begins with an anonymous voice making the following announcement through the loudspeakers:

Lavoratori $[\ldots]$ trattate la macchina che vi è stata affidata con amore, badate alla sua manutenzione. [...] La vostra salute dipende dal vostro rapporto con la macchina, rispettate le sue esigenze e non dimenticate che macchina più attenzione uguale produzione. Buon lavoro.

The symbiotic relationship the protagonist has developed with the factory machine literally replaces his love for his partner Lidia. This is epitomized by a scene in which Lidia complains about her unsatisfactory sexual life and Lulù, rather angry, replies that "a me la voglia mi viene solo al mattino quando sono in fabbrica. La sera niente. Al mattino, quando sono in fabbrica, me ne farei anche tre." In addressing their sexual life, Petri explores the sexual alienation of the main character, who literally diverts his libido "from the bedroom to the factory" (Vighi 2016a, p. 75). The protagonist channels all his energies into the workplace and, in so doing, his libido is disinvested from his love relationship with Lidia and misplaced in the factory work at the machine. As Matošević points out, "he is vital and accomplished in the solipsism of his own work success, and at home he is apathetic, constantly complaining and fighting, obsessed with the 
factory and profit" (2013, p. 21). Ultimately, his condition as an alienated factory worker is what primarily defines Lulù, providing him with a socially recognized identity.

\subsection{From a Tool to a Fool}

The protagonist is split between his conscious knowledge that he is being exploited by the factory and his unconscious libidinal attachment to the factory's capitalist mode of production. Although the notion of alienation "does not constitute part of Freud's theoretical vocabulary" (Evans 1996, p. 9), Freud's theory of the subject articulates precisely this Spaltung [splitting] between conscious thoughts and unconscious desires. ${ }^{7}$ To take this into account, "a purely economic or material explanation of the origin of alienation is inadequate" (Churchich 1990, p. 53) as it overlooks the inherent split of the subject, as posited by Freudian and Lacanian psychoanalysis. In particular, Lacan's notion of alienation is "more estranging than classic Marxist alienation, for it implies a fundamental impossibility of self-coincidence" (Valente 2003, p. 161), which ultimately results in the inability to "escape from this division" (Evans 1996, p. 9). Following Freud, Lacan states that alienation "resides in the subject's division" (Lacan 1964, p. 713) and considers it as the "fundamental" (Lacan 1950, p. 120) condition of human subjectivity. Nevertheless, Lacan also considers alienation as "constitutive" (Lacan 1957, p. 372; 1964, p. 712) of human subjectivity itself insofar as alienation contributes to, and is part of, the very process of subjectivation. For Lacan, the subject "comes into being as caught up in a constitutionally alienating situation" (Sforza Tarabochia 2013, p. 129). The subject is "alienated" inasmuch as it can at first identify and experience itself only through the Other (Lacan 1946, p. 148), which is represented and embodied by family members, society, culture, law, and institutions. For this reason, Lacan notoriously defines the unconscious as "the discourse of the Other" (Lacan 1998, p. 131).

From a Lacanian perspective, the first part of the film portrays the protagonist's alienation in his "historical Other" (Vighi 2016b, p. 417); that is to say, the Other as factory and, ultimately, the capitalist norm of production. The Other guarantees Lulù an identity, namely that of the alienated and exploited factory worker even if in so doing it "takes the subject away from its being" (Verhaeghe 1998, p. 180), totally subjugating his life. As Verhaeghe (1998, p. 180) contends, "[t]he subject wants to be loved/desired by the Other and models/alienates him or herself on the 
image of what s/he thinks is desirable for this Other." In Lulù's case, this is epitomized by his willingness to constantly increase the factory's productivity. At the beginning of the film, Lulù takes pride in being considered by his foreman as a model for his fellow coworkers and is extremely satisfied when the factory managers congratulate him for his extraordinarily good performance. According to Tomšič (2015a, p. 103), this is exactly what happens in capitalism, where the subject is placed "in the position of the object that satisfies the Other's demand for production." Lulù does not care about the unionists' protests and is not interested in joining the student-worker movement. ${ }^{8}$ Despite being exploited, he remains loyal to the factory, which gives him an identity and provides him with a sense of wholeness, and his only aim is to increase its productivity and, consequently, his salary. After all, he also believes that his devotion to the factory and his hard work will ultimately be recognized and rewarded.

However, according to Lacan's theory, beyond an initial (constitutive) alienation the process of subjectivation requires another phase that entails a separation from the Other (Lacan 1998, pp. 203-229). Only through such a separation can the subject ultimately be brought into existence. In Lacan's terms, the overlaps between alienation and separation are what define subjectivity. As Recalcati (2010, p. 154) claims: "Lacan definisce il soggetto come alienazione e separazione, dunque come agganciato fatalmente ai significanti che lo hanno determinato e che lo identificano e, al tempo stesso, come movimento di separazione da questa identificazione."

The turning point of the film occurs when Lulù cuts his finger off in an incident at work. This traumatic event causes a rupture in Lulù's relation with the factory/Other. The loss of his finger obliges him to realize not only that the factory will not provide any compensation but also that the factory managers are not interested in his psychophysical condition. Indeed, the protagonist is approached by a factory psychologist, who is solely interested in restoring his performance so that production can be reestablished. In the factory, there is no space for Lulù's subjectivity, and his body is merely considered as a machine which must become functional again as quickly as possible. It is at this point that "[a] lack is encountered in the field of the Other" (Lacan 1998, p. 214) and, consequently, Lulù begins to reassess his whole life, including his devotion to the factory.

Lulù decides to pay a visit to Militina (Salvo Randone), an old revolutionary Communist who has been ousted by the party and confined to an asylum. Although the asylum inmates are portrayed in a very stereotyped manner, at this point of the film "la questione della salute mentale e delle 
risorse da sfruttare per il recupero dei malati si intreccia strettamente [...] con quella della classe operaia" (Uva 2015, p. 60). Afraid of losing his mind, Lulù wants to know how and when Militina realized he was going mad. Militina mentions that he started noticing a psychic change owing to some mannerisms, for example when he placed cutlery on the table in a specific way. This scares Lulù since he recognizes himself in such behavior. The visit ends with Militina straightforwardly asking Lulù "cazzo fabbrichiamo noi nella fabbrica?" Lulù is unable to provide a proper answer to this question, and Militina concludes by remarking that "questa Lulù non è pazzia perché un uomo ha il diritto di sapere quello che fa, a che cosa serve."

After this meeting, a sequence almost identical to the opening scene shows a mass of workers going through the factory gates, as Lulù routinely does every day, with the anonymous voice repeating the usual announcement through loudspeakers in the background. On this occasion, however, something has changed and Lulù appears to be lost and hesitant. After the traumatic incident, Lulù has slowly begun to change his perspective, no longer interested in contributing to the production of the factory. When some foremen complain that he is underperforming, Lulù angrily states "non è che non posso, è che non ho voglia," and he shouts that they must give him back everything he has lost through his factory work, including his amputated finger. As Žižek $(2017$, p. 456) aptly points out, "[s]eparation takes place when the subject takes note of how the big Other is in itself inconsistent, lacking [...]: the big Other doesn't possess what the subject is lacking." The traumatic experience of the mutilated finger triggers Lulù's psychic breakdown, which leads him to a radical change: "from a top worker to a fierce opponent" (Matošević 2013, p. 32) of the factory and a fierce anticapitalist militant. Indeed, in the second part of the film the protagonist joins the picketers, encourages a strike, and also becomes a member of an extremist group in a violent insurrection against factory managers. The protagonist's radical mutation does not occur simply because, as Spagnoletti (2012, p. 70) argues, Lulù suddenly realizes how alienating his life is. As previously pointed out, the protagonist is already aware of his condition as an alienated and exploited worker. On the contrary, it is because he experiences first hand the "inconsistencies of the values around which [his] identit[y] [was] structured" (Vighi 2016a, pp. 73-74) by means of a bodily loss that disentangles the protagonist's libidinal attachment to the factory. There is, therefore, an "interdependency of subjectivation and alienation" (Tomšic 2015a, p. 14), and it is only by undergoing a separation from the Other that "the subject receives an element of choice" (Verhaeghe 1998, p. 182). 


\subsection{Breaking Down the Wall: Is There a Way Out?}

The final part of the film addresses Lulù's contradictory reaction to receiving this very element of choice; that is, the possibility of becoming a subject. Despite his having embraced activism, the student-worker movement is not interested in Lulù as a subject, similarly to the anonymizing factory system that produces only mass workers. This is epitomized by the harsh words that one of the protesters addresses to Lulù during a strike: "il tuo è un caso individuale, personale e non è questo che ci interessa. Noi vogliamo un discorso di classe." After receiving a dismissal notification from the factory, owing to his actions and behavior, and being denied access to the workplace, the protagonist is completely lost: there is no space for Lulù's subjectivity either in the factory or in the student-workers' movement. However, without his (alienating) job the protagonist is now utterly deprived of his identity as an (alienated) factory worker, which was the main justification for his entire existence. Indeed, during an emotional scene at the factory gates, the protagonist shouts in despair: "Dove vado? Dove andiamo noi [lavoratori disoccupati]? Andiamo a scuola? Andiamo a teatro? Al cimitero?" For Lulù, the only viable option is to return to the factory assembly line and regain that secure, albeit alienated, identity.

During another visit to the asylum, Militina discourages the protagonist from returning to the factory and claims that: "se vuoi diventare matto credi a me devi tornare in fabbrica. Io sono diventato matto in fabbrica." After this comment, Militina begins to shout "giù il muro! Il muro ... giù ... giù!" with all the other asylum inmates repeating the same sentence. Lulù leaves the asylum rather upset and, once home, starts estimating all the objects there in terms of the working hours he had to accumulate to buy them. This scene is followed by an angry outburst, when the protagonist destroys an inflatable Scrooge McDuck toy, possibly a subtle reference to the capitalist world (Vighi 2016a, p. 81), and to the cry of "cosa controlli?! Ma cosa controlli?!" When Lidia and her son find him in the living room, he is uncannily repeating the word "il muro, il muro, il muro," exactly as Militina did in the asylum. Clearly, Lulù is torn between accepting his new uncertain condition and his previous life at the factory. In the scene that follows, Lulù is finally informed by some colleagues that he has been granted readmittance to the factory. Surprisingly, he appears rather shocked and not particularly happy about the news. At this point, for the third time, the camera shows the beginning of a working day at the factory, the crowd of workers entering the gates, the picketers shouting their slogans, and the workers starting up their machines. 
The protagonist is back on the factory assembly line, exactly where he was at the beginning of the film, wearing his factory uniform and totally absorbed in the repetitive routine at the machine. Undoubtedly, this signals Lulù's refusal to become a (separated) subject and his complete identification with the semblant of the (alienated) factory worker. In the final scene, Lulù tells his fellow workers about a dream he had the night before, which revolves around a wall that was pulled down and a thick fog that surrounded him. When they ask him what was there, Lulù replies that "prima niente poi ho incominciato a guardare e ci ho visto venir su il Militina. Poi ho visto un manovale, ho visto un pirla con un dito di meno e ho detto "ma chi è quello lì?" e penso ma quello li sono io! Uno a uno siete venuti avanti tutti. C'eravamo noi altri." Finally, his coworkers ask "ma cosa vuol dire?" The protagonist enigmatically replies "vuol dire che se c'è un muro da buttar giù si butta giù."

The radically pessimistic ending (Fofi 1977, p. 246; Spagnoletti 2012, p. 67; Williams 2013, p. 56; Vighi 2016a, p. 78) raises several questions: to which wall are Militina and Lulù referring? Is it the actual wall of the asylum where Militina is confined or the factory wall where Lulù and his fellow workers are secluded? Does it represent the wall of capitalist ideology (Bondanella 2009, p. 245; Vighi 2016a) or the wall of alienation itself? Ultimately, can it be pulled down? The protagonist, along with the spectator, is left without a proper answer. As Williams (2013, p. 59) puts it,

The film won't say, or even hint at, how this vicious cycle might be broken. It ends, horrifically, with a return to work, a slog back to the factory where a new arrangement of production (the deafening assembly line) awaits, as though 'victory' was nothing more than a minor modification of the intolerable.

Petri's pessimism rests on the lack of a viable alternative to the assembly line and the depiction of the working class as being irremediably compromised by capitalism. Nevertheless, I have contended that a Lacanian perspective reveals the potentially transformative power of alienation and therefore sheds a different light on the ending of the film. Indeed, Lacan's account of alienation draws a distinction between individual constitutive alienation, which partakes in the process of subjectivation, and constituted alienation, which refers to the sociohistorical form of alienation. If we try to retrieve the subject from its fundamental (and constitutive) alienation, as in Lulù's dream, we will get nowhere and be lost in the same thick fog as Lulù in his dream. Ultimately, "the subject is nothing but this very 
split" (Fink 1997, p. 45); that is to say, alienation is also a fundamental part of the subject. In this respect, constitutive alienation cannot be reduced to the capitalist form of (social) alienation. The latter prevents the individual from becoming a subject as it encourages its subjection to the Other as Market. According to Lacan (2017), the discourse of the capitalist rejects the constitutionally and fundamentally alienated condition of human subjectivity and forecloses the fundamental division inherent in all human beings. If Lacan defines the discourse of the capitalist as "pazzescamente astuto" (Contri 1978, p. 48), this is precisely because it "rejects the paradigm of negativity, castration: the symbolic operation that constitutes the subject as split and decentralised" (Tomšič 2015a, p. 152). The discourse of the capitalist is pervasive and unstoppable as it promises to disalienate human beings without undergoing separation by making us believe that the subject's lack is purely contingent and, as such, can be filled by any commodity available from the market.

In conclusion, from a Lacanian perspective, the actual political kernel of this film is not simply the representation of the exploited, miserable condition of the factory workers but rather Petri's cinematic representation of the potentially transformative force of (individual) alienation and its link with the constitution of the subject. ${ }^{9}$ As Vighi (2016a, p. 86) contends, "[b]ecoming aware of this gap separating socially-determined alienation from the ontological division of the subject is perhaps the true political lesson of Petri's film." To rephrase one of the most well-known statements by Lacan, ${ }^{10}$ I would claim that Petri's film clearly shows that alienation is politics. Constitutive alienation offers a transformative opportunity by playing a central role in enabling an individual to become a subject, pushing the individual towards separation and, thus, subjectivation. According to Lacan's theory, the capitalist form of (social) alienation "is not our ultimate destiny, it can be overcome, but not in the triumphalist humanist sense" (Žižek 2017, p. 456). Lacan's position is neither the "naïve Marxist idea of sexual and economic liberation which allows us to break out of alienation nor [the] psychoanalytic dismissal of every revolutionary project as imaginary illusion" (Žižek 2017, p. 452). Lacan's third way rests on a conception of the subject as the actual agent of a real revolutionary process. In Lacan's words, alienation "leaves it up to the subject to butt up against the question of his essence" (Lacan 1960, p. 690) and, consequently, to find "self-realization beyond alienation" (Tomšič 2015a, p. 91). Arguably, this is the "way out of the capitalist discourse" (Lacan 1990 , p. 16), the only way to break down the wall of historically determined alienation without letting the subject disappear into the thick fog. 


\section{Notes}

1. Despite its success, the film was harshly criticized by the Italian left (Matošević 2013, p. 36; Marrone 2016, p. 24) and, especially in early twenty-first-century, overlooked and neglected (Veltroni 2012, p. 11). A reappraisal of this "controversial" film (Vighi 2016a, p. 74) is thus not only beneficial for promoting Petri's cinema, particularly in Anglophone scholarship, but also for appreciating its topicality in post-millennial society (Williams 2013).

2. The film was shot in a factory in northern Italy (Novara) occupied by workers on strike, who ended up working as extras. Interestingly, that factory was the only one, amongst several selected as potential sets for the film, to grant Petri permission to shoot his film on the alienation of factory workers (Rossi 1979; Portis 2010b).

3 . This approach was severely criticized. For example, Allonge and Rivero (1971) contend that the focus on the existential crisis is entirely unrelated to the context of the working-class struggle, and Fofi $(1977$, p. 246) claims that the film does not go deeply enough on either a sociological or a psychological level.

4. As Matošević (2013, p. 36) points out, the film was characterized by an "indifferent and almost critical reception $[\ldots]$ on the part of the Italian left." In particular, Spagnoletti $(2012$, p. 67$)$ underlines that "il film scontentava tutti coloro che in teoria avrebbero dovuto apprezzarlo e/o sostenerlo: il partito comunista, il sindacato, la sinistra extraparlamentare, la critica ispirata al brecht-godardismo." Criticisms from the left culminated in the reaction of Jean-Marie Straub who, during the premiere of the film at the Porretta Festival in 1971, "called for La classe operaia to be burned" (Brunetta 2009, p. 235). Amongst the reasons for these criticisms, scholars have identified: the portrait of extremely negative traits of the protagonist, which shed a negative light on the working class as a whole (Spagnoletti 2012); a "confused pro-labour ideology" (Moliterno 2008, p. 249); the controversial depiction of unionists and the student movement (Spagnoletti 2012); the controversial ending that conveys the impossibility of a proper revolution and, therefore, not a real intention on Petri's part to promote social change (Uva 2015, pp. 24-26); and "an excessive spectacularity [which] called for emotional rather than intellectual spectatorial investment" (Lombardi and Uva 2016, pp. 7-8) and ultimately contributed to the perception of this film as "strongly compromised with [...] capitalist values" (Lombardi and Uva 2016, p. 8).

5. For a discussion on Marx's influence on Lacan's theory see: Žižek (1989, 1996), Valente (2003), Flower MacCannell (2006), Pavón-Cuéllar (2011), Bianchi (2012), Tomšič $(2012,2015 a, b)$, Feldner and Vighi (2015), Vighi (2016b, 2018). 
6. For Lacan (2007a), all human social relations can be reduced to four fundamental discursive models: the discourse of the Master; the discourse of the University; the discourse of the Analyst; and the discourse of the Hysteric. In Seminar XVIII (Lacan 2007b) and in the conference paper "Du discours psychanalytique," delivered in Milan on May 12, 1972 (Contri 1978, pp. 32-55), Lacan adds a fifth discourse that he denominates the Discourse of the Capitalist.

7. According to Vighi, this Freudian stance is the "overriding cipher of Petri's cinema, manifesting itself in a number of variations on the theme of neurosis" (2016a, p. 72). Unsurprisingly, La classe operaia va in paradiso is the second film of the so-called trilogia della nevrosi, which focuses on neurosis in relation to work. The other two films of the trilogy are Indagine su un cittadino al di sopra di ogni sospetto (1970), which focuses on neurosis in relation to power, and La proprietà non è più un furto (1973), which focuses on neurosis in relation to money (Di Giammatteo 1994, p. 356).

8. In this respect, Spagnoletti $(2012$, p. 71$)$ claims that the film is rather premonitory of the trajectory from the "impegno pregno di ideologia utopista del Sessantotto" to the "progressivo disimpegno degli anni a seguire, sino all'individualismo esasperato del presente."

9. The issue of Petri's political commitment in his films has always been highly disputed amongst scholars. For instance, Fofi considers Petri's cinema as "non-political" $(1977$, p. 246). On the contrary, scholars such as Rossi (1979), Bondanella (2009), and Lombardi and Uva (2016) regard Petri's cinema as predominantly political and consider La classe operaia as the "best example of the Italian political film" (Bondanella 2009, p. 242), a factory film (Williams 2013, p. 54), and a political film (Rossi 1979, p. 25), which is characterized by a "political-popular style" (Rugo 2015, p. 106).

10. I am referring here to the renowned Lacanian statement "the unconscious is politics" (Lacan 1967).

\section{REFERENCES}

Allonge, Roberto, and Roberta Rivero. 1971. La classe operaia va in paradiso. Cinema nuovo 20 (213): 373.

Antonello, Pierpaolo. 2016. Il divo: Paolo Sorrentino's Spectacle of Politics. In Italian Political Cinema: Public Life, Imaginary, and Identity in Contemporary Italian Film, ed. Giancarlo Lombardi and Christian Uva, 291-304. Bern/ Oxford: Peter Lang.

Bianchi, Pietro. 2012. From Representation to Class Struggle. S: Journal of the Circle for Lacanian Ideology Critique 5: 114-126.

Bondanella, Peter. 2009. A History of Italian Cinema. New York: Continuum. 
Brunetta, Gian Pietro. 2009. The History of Italian Cinema: A Guide to Italian Film from Its Origins to the Twenty-First Century. Princeton: Princeton University Press.

Churchich, Nicholas. 1990. Marxism and Alienation. Madison: Fairleigh Dickinson University Press.

Contri, Giacomo, ed. 1978. Lacan in Italia/En Italie Lacan: 1953-1978. Milan: La Salamandra.

Dean, Tim. 2000. Beyond Sexuality. Chicago: University of Chicago Press.

Di Giammatteo, Ferdinando. 1994. Lo sguardo inquieto: Storia del cinema italiano (1940-1990). Florence: La Nuova Italia.

Evans, Dylan. 1996. An Introductory Dictionary of Lacanian Psychoanalysis. London: Routledge.

- 1998. From Kantian Ethics to Mystical Experience: An Exploration of Jouissance. In Key Concepts of Lacanian Psychoanalysis, ed. Dany Nobus, 1-28. New York: Other Press.

Feldner, Heiko, and Fabio Vighi. 2015. Critical Theory and the Crisis of Contemporary Capitalism. London: Bloomsbury.

Fink, Bruce. 1997. The Lacanian Subject: Between Language and Jouissance. Princeton: Princeton University Press.

Flower MacCannell, Juliet. 2006. More Thoughts for the Times on War and Death: The Discourse of Capitalism in Seminar XVII. In Jacques Lacan and the Other Side of Psychoanalysis: Reflections on Seminar XVII, ed. Justin Clemens and Russel Grigg, 195-215. Durham: Duke University Press.

Fofi, Goffredo. 1977. Capire con il cinema: 200 film prima e dopo il '68. Milan: Feltrinelli.

Lacan, Jacques. 1946. Presentation on Psychical Casuality. In Lacan, Jacques. Écrits: The First Complete Edition in English, 123-158. Trans. Bruce Fink. London: W.W. Norton \& Co.

- 1950. A Theoretical Introduction to the Functions of Psychoanalysis in Criminology. In Lacan, Jacques. Écrits: The First Complete Edition in English, 102-122. Trans. Bruce Fink. London: W.W. Norton \& Co.

- 1957. Psychoanalysis and Its Teaching. In Lacan, Jacques. Écrits: The First Complete Edition in English, 364-383. Trans. Bruce Fink. London: W.W. Norton \& Co.

- 1960. The Subversion of the Subject and the Dialectic of Desire in the Freudian Unconscious. In Lacan, Jacques. Écrits: The First Complete Edition in English, 671-702. Trans. Bruce Fink. London: W.W. Norton \& Co.

- 1964. Position of the Unconscious. In Lacan, Jacques. Écrits: The First Complete Edition in English, 703-721. Trans. Bruce Fink. London: W.W. Norton \& Co.

- 1967. La logique du fantasme. Unpublished seminar. 
1990. Television/A Challenge to the Psychoanalytic Establishment (1973).

Trans. Rosalinde Krauss and Annette Michelson. London: W.W. Norton \& Co.

- 1998. The Four Fundamental Concepts of Psychoanalysis: The Seminar of Jacques Lacan, Book XI, 1963-1964. Trans. Alan Sheridan. London: W.W. Norton \& Co.

- 2007a. The Other Side of Psychoanalysis: The Seminar of Jacques Lacan, Book XVII, 1969-1970. Trans. Russell Grigg. London: W.W. Norton \& Co.

- 2007b. Le Séminaire. Livre XVIII: D'un discours qui ne serait pas du semblant. Paris: Seuil.

- 2017. Talking to Brick Walls: A Series of Presentations in the Chapel at Sainte-Anne Hospital. Trans. Adrian Price. Cambridge: Polity Press.

Lombardi, Giancarlo, and Christian Uva. 2016. Italian Political Cinema: Definitions and Goals. In Italian Political Cinema: Public Life, Imaginary, and Identity in Contemporary Italian Film, ed. Giancarlo Lombardi and Christian Uva, 3-13. Bern/Oxford: Peter Lang.

Marrone, Gaetana. 2016. Italian Political Cinema: The Early Masters. In Italian Political Cinema: Public Life, Imaginary, and Identity in Contemporary Italian Film, ed. Giancarlo Lombardi and Christian Uva, 17-29. Bern/Oxford: Peter Lang.

Marx, Karl. 1988. Economic and Philosophic Manuscripts of 1844. Trans. Martin Milligan. New York: Prometheus Books.

Matošević, Andrea. 2013. “This Is a Matter of Numbers, Not of Heart:” Re-signing Shock Labor in 1970s Film. Narodna umjetnost 50 (1): 12-39.

McGowan, Todd. 2004. The End of Dissatisfaction? Jacques Lacan and the Emerging Society of Enjoyment. Albany: State University of New York Press.

- 2016. Capitalism and Desire: The Psychic Cost of Free Markets. New York: Columbia University Press.

Miccichè, Lino. 1980. Cinema italiano degli anni '70: Cronache 1969-78. Venice: Marislio.

Moliterno, Gino. 2008. Historical Dictionary of Italian Cinema. Toronto: The Scarecrow Press.

Mondella, Diego, ed. 2012. L'ultima trovata: Trent'anni di cinema senza Elio Petri. Bologna: Edizioni Pendragon.

Musto, Marcello. 2010. Revisiting Marx's Concept of Alienation. Socialism and Democracy 24 (3): 79-101.

Pavón-Cuéllar, David. 2011. Marx in Lacan: Proletarian Truth in Opposition to Capitalist Psychology. Annual Review of Critical Psychology 9: 70-77.

Portis, Larry. 2010a. The Director Who Must (Not?) Be Forgotten: Elio Petri and the Legacy of Italian Political Cinema, Part 1. Film International 8 (2): 17-29.

- 2010b. The Director Who Must (Not?) Be Forgotten: Elio Petri and the Legacy of Italian Political Cinema, Part 2. Film International 8 (4): 42-50. 
Recalcati, Massimo. 2010. L'uomo senza inconscio: Figure della nuova clinica psicoanalitica. Milan: Raffaello Cortina.

Rigola, Gabriele, ed. 2015. Elio Petri, nomo di cinema: Impegno, spettacolo, industria culturale. Rome: Bonanno Editore.

Rossi, Alfredo. 1979. Elio Petri. Florence: La Nuova Italia.

Rugo, Daniele. 2015. The Pedagogy of Political Film. Elio Petri's Todo Modo. Studies in European Cinema 12 (2): 106-117.

Sforza Tarabochia, Alvise. 2013. The Aphanisis of the Pirandellian Subject. Italian Studies 68 (1): 123-137.

. 2016. From the Obligation of Birth to the Obligation of Care: Esposito's Biophilosophy and Recalcati's "New Symptoms". Culture, Theory and Critique 58 (1): 1-15.

Spagnoletti, Giovanni. 2012. Una nota su La classe operaia va in paradiso. In L'ultima trovata: trent'anni di cinema senza Elio Petri, ed. Diego Mondella, 67-72. Bologna: Edizioni Pendragon.

Tomšič, Samo. 2012. Homology: Marx and Lacan. S: Journal of the Circle for Lacanian Ideology Critique 5: 98-113.

- 2015a. The Capitalist Unconscious: Marx and Lacan. London: Verso.

- 2015b. Psychoanalysis, Capitalism, and Critique of Political Economy: Toward a Marxist Lacan. In Jacques Lacan Between Psychoanalysis and Politics, ed. Samo Tomšič and Andreja Zevnik, 146-163. London: Routledge.

Tomšič, Samo, and Andreja Zevnik. 2015. Introduction. In Jacques Lacan Between Psychoanalysis and Politics, ed. Samo Tomšič and Andreja Zevnik, 1-11. London: Routledge.

Uva, Christian. 2015. L'immagine politica: Forme del contropotere tra cinema, video e fotografia nell'Italia degli anni Settanta. Milan: Mimesis.

Valente, Joe. 2003. Lacan's Marxism, Marxism's Lacan (from Žižek to Althusser). In The Cambridge Companion to Lacan, ed. Jean-Michel Rabaté, 153-172. Cambridge: Cambridge University Press.

Veltroni, Walter. 2012. Prefazione. In L'ultima trovata: Trent'anni di cinema senza Elio Petri, ed. Diego Mondella, 11-12. Bologna: Edizioni Pendragon.

Verhaeghe, Paul. 1998. Causation and Destitution of a Pre-ontological Nonentity: On the Lacanian Subject. In Key Concepts of Lacanian Psychoanalysis, ed. Dany Nobus, 164-189. New York: Other Press.

Vighi, Fabio. 2006. Traumatic Encounters in Italian Film: Locating the Cinematic Unconscious. Bristol: Intellect.

- 2016a. Belief as Fetish: The Religion of Capitalism in Elio Petri's Cinema. In Requiem for a Nation: Religion and Politics in Post-War Italian Cinema, ed. Roberto Cavallini, 71-87. Milan: Mimesis International.

- 2016b. Capitalist Bulimia: Lacan on Marx and Crisis. Crisis and Critique 3 (3): 415-432. 
2018. Crisi di valore: Lacan, Marx e il crepuscolo della società del lavoro. Milan: Mimesis.

Williams, Evan Calder. 2013. The Fog of Class War: Elio Petri's The Working Class Goes to Heaven, Four Decades On. Film Quarterly 66 (4): 50-59.

Žižek, Slavoj. 1989. The Sublime Object of Ideology. London: Verso. . 1996. The Fetish of the Party. In Lacan, Politics, Aesthetics, ed. Willy Apollon and Richard Feldstein, 3-29. Albany: State University of New York.

. 2017. The Politics of Alienation and Separation: From Hegel to Marx... and Back. Crisis and Critique 4 (1): 447-479.

\section{Filmography}

Petri, Elio, dir. 1970. Indagine su un cittadino al di sopra di ogni sospetto. Rome: Euro International Film. Film.

- dir. 1973. La proprietà non è più un furto. Rome/Paris: Quasars Film Company and Labrador Film. 


\section{The Asylum}




\section{Manicomiche: Madness, Language and the Dismantling of the Asylum in Gianni Celati's Comiche}

Michele Ronchi Stefanati

A un certo punto c'è stato un amico che lavorava all'ospedale psichiatrico di Pesaro che ha cominciato a portarmi questi fascicoli dei matti, in particolare di uno che io trovavo geniale. Poi ero molto amico di Basaglia e lui trovava che quello che facevo era essenziale, cioè capire cosa c'è in questa intensità dei matti quando scrivono. Basaglia non era un gran teorico, era proprio un uomo alla mano, l'ho amato davvero. Dopo sono stato militare e mi sono ammalato e poi mi è venuto da scrivere come $i$ matti, a titolo sperimentale

Barbolini (2009)

\subsection{INTRODUCTION}

Gianni Celati styled his debut book Comiche, published in 1971 after a long process of rewriting, on the diary of an inmate at the mental hospital in Pesaro. This choice reflects the different beliefs that informed Celati's

M. Ronchi Stefanati $(\bowtie)$

University College Cork, Cork, Ireland

(C) The Author(s) 2019

A. Diazzi, A. S. Tarabochia (eds.), The Years of Alienation in Italy, https://doi.org/10.1007/978-3-030-15150-8_10 
idea of literature from the beginning to the very end, such as the importance of non-literary texts as a model for his writing and the attention to language, which, in the first phase of his career as a writer, namely the 1970s, takes the form of linguistic experimentation and subversion of language. In this chapter, I propose an innovative reading of Celati's Comiche, suggesting that his use of comical effects, which recreates in writing the model of slapstick films, enables him to criticize the asylum and polemicize against it, showing aspects of this oppressive institution through the literary strategies he uses. First, I will demonstrate how Celati was involved in the debate on mental health in the 1970s, through direct contact with one of the main protagonists of the Italian radical psychiatry movement, Franco Basaglia, and how this deeply influenced his works. Then, I will analyze passages from Comiche to show why this text should be considered Celati's own contribution to the debate on mental health, within the wider criticism of violent institutions that characterizes all of his books from the 1970s. As West points out, all of Celati's novels that followed Comiche, namely Le avventure di Guizzardi (1972), La banda dei sospiri (1976a), and Lunario del paradiso (1978a) need to be seen as "semi-autobiographical works, in which anarchical young protagonists seek to make their way in a world dominated by repressive families and frightening authority figures," and they "reflect the rebellious mood of the late sixties" (West 2000 , p. XII). In his works from the 1970s, Celati mocks and undermines the institutions and authorities of the time, such as asylums, schools, universities, political parties, and also the army and the family.

\subsection{Origins of Comiche}

In the inmate's notebooks (unpublished, entitled by the author L'organo mazziniano dell'ospedale psichiatrico di Pesaro) that served as a model for Comiche, Celati found a perfect example of a form of writing that rejects plot and undermines the rules of standard Italian. At the time of writing Comiche, Celati was a schoolteacher and appreciated the "anarchic effect" of his pupils' essay writing:

A me interessa una lingua di pure carenze. Un po' ho capito la cosa quando insegnavo in campagna, alla scuola media. I ragazzini scrivevano il loro italiano, il loro abile (perché frutto di una esperienza ormai secolare) adattamento all'italiano, con una capacità di ironia e di tensione che mi sbalordivano; altroché infantilismo; i loro equivoci erano, voluti o no, dei 
capolavori di contestazione. L'insegnante di italiano poi interveniva a correggere proprio là dove l'effetto era più piacevolmente anarchico, dove la frase seguiva la curva del parlato, dove la frase si allungava straordinariamente per una specie di incontinenza affabulatoria; dove le ellissi saltavano necessità che l'italiano cartaceo conserva come forme atrofizzate. Il disadattamento della lingua è disadattamento al mondo cartaceo-paranoico-verbo delirante. (Celati 2016b) ${ }^{1}$

According to Celati, the language of his students' compositions recreated on paper the effect of spoken Italian, subverting grammar rules. The inmate's notebooks fascinated Celati because of a similar linguistic freedom, but also because of his long-standing interest in the topic of madness. During military service in 1962 Celati fell ill with hepatitis, and the following winter he was quarantined in his parents' house in the countryside. It was there that he read the inmate's notebooks and started to model his writing on them. When the poet Spatola visited Celati in quarantine, he found the first few pages of Comiche and decided to publish them in the journal Uomini e idee, in 1966. Sanguineti read them and submitted Celati's work to the publisher Einaudi. This was the starting point of Celati's long-lasting collaboration with Einaudi, for which he would be a key author, translator, and advisor from the mid-1960s to the end of the 1970s. The relationship between Celati and Einaudi involved other important figures of the Italian intellectual and literary landscape, such as Manganelli, Calvino, Davico Bonino, Fossati, and many others (Ronchi Stefanati 2017). The collaboration with Einaudi also enabled Celati to meet the psychiatrist Basaglia, with whom he shared a room during the summer meetings that Giulio Einaudi organized between the editorial board and the authors, held in Rhêmes-Notre-Dame, a mountain village in the Aosta Valley (Ferrero 2005, 2008).

In those years, Celati was also interested in slapstick comedy, particularly films starring Keaton, Chaplin, Langdon, Laurel and Hardy, Tati, Lloyd, and the Marx Brothers, and these films played a key role in the development of Celati's narratives. This crucial aspect of his oeuvre, not limited to the 1970s, has been widely investigated by scholars, and had already been made explicit at the time of publication of Comiche, not only through the title, but also thanks to Calvino's postface to the book, which highlighted aspects linked to slapstick comedies (Calvino 2008; Ottone 1972; La Polla 1972; Caesar 1986; Iacoli 2012). Celati's second book, Le avventure di Guizzardi (1972), featured the comedian Lloyd on the cover, 
and Celati wrote a long essay on comedy, significantly titled Harpo's Bazaar, using the name of his favorite Marx Brother (the same name returns in 1977 as the name of the group of documentarists of whom Celati is part; see Ronchi Stefanati 2015). The essay was partly published in Il verri in 1976 with the title "Il corpo comico nello spazio." At the beginning of the 1970s, Celati even discussed with Giulio Einaudi a project of comic strips, which should have included, as well as the abovementioned American actors and directors, the popular Italian comedian Totò (Palmieri 2016).

\subsection{Celati and the Antipsychiatric Movement}

Celati's interest in the writings of the insane began while he attended the University of Bologna, at the beginning of the 1960s. It was there that he met the philosopher Melandri and read his La linea e il circolo, a text that Celati often mentions was fundamental for his career (Palmieri 2016, p. LXXXIV). Through Melandri, Celati became acquainted with the study of mental illness and the art made by psychotic patients. He translated some writings of the painter Wölfli, who died in the psychiatric hospital in Waldau after more than thirty years of imprisonment, and to whom the psychiatrist Morgenthaler dedicated his book Ein Geisteskranker als Künstler (A Psychiatric Patient as Artist) in 1921. It is in this same period that Celati first read Freud's key texts, particularly Zur Psychopathologie des Alltagslebens (The Psychopathology of Everyday Life, 1904), Der Witz und seine Beziehung zum Unbewussten (Jokes and Their Relation to the Unconscious, 1905a), and Drei Abhandlungen zur Sexualtheorie (Three Essays on the Theory of Sexuality, 1905b). Celati was also influenced by case histories, such as Freud's Psychoanalytische Bemerkungen über einen autobiographisch beschriebenen Fall von Paranoia (Psycho-Analytic Notes on an Autobiographical Account of a Case of Paranoia, 1911). This work focuses on the case study of the German judge, Daniel Paul Schreber, who described his schizophrenia in the book Denkwürdigkeiten eines Nervenkranken (Memoirs of My Nervous Illness, 1903). Celati often mentions Schreber's case in his essays from the 1970s, included in his 1975 collection Finzioni occidentali (2001a), and it would later have extraordinary importance in the collective volume Alice disambientata (1978b), based on Celati's seminars at the Department of Music, Art and Theatre (DAMS) in Bologna (Celati 2007a) in 1977. 
Celati's essays from the 1970s reveal that his interest in the debate on mental health in all its aspects continues well beyond his readings. Comiche was born within a cultural climate deeply influenced by the debate on mental illness. A leading figure of Italian radical psychiatry and a protagonist of this debate was unquestionably Basaglia, whose thought and practices as a director of the asylums of Gorizia (1961-1969) and Trieste (1971-1979) led to the decommissioning of mental hospitals in Italy. Basaglia was convinced that the entire asylum system reduced inmates to "non-persons." In his view, there were no medical benefits to the way mental disorders were treated inside asylums. On the contrary, Basaglia thought that the inmates' behavior was caused by the institutions themselves. Basaglia saw asylums as places like prisons or concentration camps, that is to say "total institutions," according to Goffman's definition in Asylums (1961). Basaglia was also profoundly influenced by Foucault's Histoire de la folie à l'âge classique (History of Madness, 1961), which studies the history of the asylum institution as an instrument to contain deviance. Basaglia furthermore established an active dialogue with so-called antipsychiatrists, such as Cooper and Laing. As a director of mental hospitals, Basaglia put into practice a series of radical reforms aimed at improving the inmates' conditions: he introduced voluntary hospitalization, discontinued shock therapies, dismantled closed wards, barriers, and walls, and, above all, introduced general meetings involving patients in the decision-making processes of the hospitals themselves. Basaglia's ideas and practices had a central role in the 1968 protest movement, as he saw a direct connection between the reform of the mental hospitals and the revolutionary transformation of bourgeois society (Foot 2015).

Celati wrote Comiche over a period of roughly eight years, from 1963 to its publication in 1971: he thus worked on it simultaneously with Basaglia's activity. In the same period, some of the landmark texts of a new approach to madness and psychiatric thought were published: Laing's The Divided Self(1960), Goffman's Asylums (1961), Foucault's Histoire de la folie (1961), Derrida's L'écriture et la différence (1967), Basaglia's L'istituzione negata (1968), Wolfson's Le schizo et les langues (1970), with a preface by Deleuze. ${ }^{2}$ Celati was also one of the first enthusiastic readers of Deleuze and Guattari's Anti-CEdipe: already in 1972 he had suggested to Einaudi that the first volume of the book, Capitalisme et schizophrénie (1972), should be translated into and published in Italian. Celati makes constant references to all of these works in his writings from this period. 
In particular, these texts represent the cultural background of the essays included in Finzioni occidentali (2001a).

Celati's early interest in madness is confirmed by other texts that precede his debut novel Comiche. In 1968, Celati collaborated with Calvino, Melandri, the scholar of French literature Neri, and the historian Ginzburg on a new journal, Ali Babà. In his list of materials to be included, Celati mentioned tales linked to madness and the antipsychiatry movement, and quoted Laing's The Divided Self as one example of what he meant:

10) registrazioni di racconti orali (matti; visionari, per es. quel portiere milanese che ha visto i marziani; disgraziati d'ogni tipo; cittadini normalissimi e pendolari); o racconti tipo documenti, nel senso dei franchi narratori di Feltrinelli; [... 13) casi clinici (il modello può essere il cap. di L'io diviso di Laing intitolato 'Il giardino delle erbacce'). (Barenghi and Belpoliti 1998, p. 134)

When Celati wrote his key essay for the journal, "Il bazar archeologico," in which he discussed the topic of marginality, he referred to "madmen's tales" as examples of the reemergence of apparently minor texts previously excluded from the literary canon. Among these, there are many references to the texts above, such as Schreber's Memoirs of My Nervous Illness and Morgenthaler's monograph on Wölfi and Wolfson's writings. It is clear, therefore, that while writing Comiche, Celati was involved in the wider debate on madness that was raging during those years.

Celati, however, expressed his doubts on how to represent madness. This seems to be strictly connected to the writing of his debut book, as Comiche is indeed a representation of madness from the perspective of the insane man himself, using his own language. In Il bazar archeologico, Celati questions the very possibility of writing in the name of the insane, adopting Derrida's perspective in his response to Foucault's Histoire de la folie. Celati quotes Derrida's L'écriture et la différence to express how difficult it is to render irrational thoughts in a rational manner:

Il folle, come tutte le estraneità, non può farci da specchio, se non razionalizzando la nozione di follia e di estraneità, a tutto vantaggio di chi usa quella nozione come difesa, a tutto svantaggio di chi quella nozione designa. Su questo punto abbastanza importante, con cui anche l'antipsichiatria deve fare i conti, Derrida ha detto qualcosa da non dimenticare: 'La disgrazia dei folli, la disgrazia interminabile del loro silenzio, è che i loro migliori portaparola sono quelli che li tradiscono meglio; il fatto è che quando si vuol 
dire il loro silenzio in sé, si è già passati al nemico e dalla parte dell'ordine, anche se, nell'ordine, ci si batte contro l'ordine e lo si mette in questione alla sua origine. (Celati 2001b, p. 215)

This is what Celati wanted to avoid in his book, Comiche: through his manipulation of language he aimed at making a portrait of madness and the asylum without betraying the position of marginality of the insane. He shaped his use of language around the diary of an inmate in an asylum, and he did so to create an effect of bagarre. This enabled him to somehow "side" with disorder, subverting "normal" or everyday language. I argue that subverting language functions as criticism of the asylum itself, as it permits the author to give a representation of the intrinsic violence of the mental hospital, while at the same time mocking it. In line with Basaglia, Celati reveals in Comiche the violent institutional nature of the asylum, as it is concealed under the semblance of a medical establishment. Parody is the instrument Celati chose to undermine it. The language of the inmate criticizes the asylum as it represents its violence by means of slapstick comedy. I will return to this point later in the chapter in order to better explain this mechanism. The language Celati uses in this text enables him to uncover the pointlessness of asylums, even if his critique is conveyed through parody rather than through a realist account. In the second part of this chapter, I will give examples of how Celati's use of the inmates' language recreates comical situations, similar to the bagarre, and how these represent a subversion of hierarchies and values while they also enable Celati to let the insane speak, without assuming upon himself the role of spokesperson of madness.

Celati's interest in madness did not stop with the publication of Comiche. In 1976, he referred again to the debate on madness, this time in his letters to the Einaudi editorial board. Celati accused the publisher of having marginalized him because of his eccentricity, while at the same time promoting authors, suggested by Celati himself, with a radically different idea of literature. ${ }^{3}$ In a letter to Davico Bonino, a member of the Einaudi editorial board, Celati compares his situation to that of a collaborator of the bourgeois establishment who conspires in the imprisonment of the insane in mental institutions (Francioso 2009; Ronchi Stefanati 2017). Celati, along with Basaglia (1968) and antipsychiatry, compared the bourgeois order with psychiatry, a comparison that is rooted in Foucault's work: 
Come si collabora con la giustizia borghese dando pareri che portano alla chiusura dei malati di mente nel manicomio, così ora penso che si collabori egualmente con la giustizia borghese accettando che gli altri ti prendano per un matto, un deviante, uno strambo, e che come tale ti concedano una marginalità di sopravvivenza. Come gli omosessuali credo che sia ora di uscire dai cessi a fare le nostre pratiche 'sporche.' Perciò non accetto questa marginalità di sopravvivenza che mi è stata concessa mettendomi a dare pareri su questa collana. (Celati 1976c)

Besides giving another example of Celati's proximity to Italian radical psychiatry, the letter clearly conveys the influence of the climate of the 1977 protests and demonstrations. In particular, it demonstrates the close link between Celati's works and the transformation of society during those years. From autumn 1976 to the end of 1977, Celati taught a seminar on nonsense literature at the University of Bologna, one of the epicenters of the 1977 protests (Belpoliti 2001; Celati 2007b; Righi 2011). ${ }^{4}$ The book based on the seminar, Alice disambientata (Celati 1978b), once again made reference to the authors quoted above, particularly to Freud, Foucault, and Deleuze and Guattari's Anti-CEdipe (Celati 1978b, 2007a). In the same years, Celati was a friend and colleague of the poet, scholar, and performer Scabia, himself closely connected to Italian radical psychiatry. Scabia worked with Basaglia for the staging of Marco Cavallo, a play/ event organized at the mental hospital in Trieste in 1973, while Basaglia was the director of the institution. The final action of the play was to dismantle the barriers of the mental hospital and let the inmates escape. A blue papier-mâché horse (Marco Cavallo), followed by the patients, "invaded" the city of Trieste as a symbol of the liberation of the insane from the constraining world of the asylum. Marco Cavallo itself was initially Basaglia's idea, and it was the product of a group effort of the patients, who were both authors of the collective text and actors in the play (Scabia 2011). Marco Cavallo represents a key symbolic moment in Basaglia's struggle for the abolishment of asylums. Celati and Scabia were both teaching at DAMS, and they worked together on Scabia's Gorilla Quadrumàno (1974) and Fantastica visione (staged in 1979). In his 1976 brief text La bottega dei mimi, Celati spoke of his participation in Gorilla Quadrumàno, ironically talking about himself in the third person and referring again to slapstick movies and the Marx Brothers in particular: 
L'altro si è messo a seguire i percorsi del gruppo del Gorilla Quadrumàno facendo anche lui teatro di strada, progettando un itinerario dei comici assieme a Giuliano Scabia e cercando di fare uno spettacolo di strada ricavato dai fratelli Marx. (Celati and Gajani 2017, p. 172)

Finally, Celati personally met both Foucault and Derrida, while the three were lecturing at Cornell University (Ithaca, New York), at the beginning of the 1970s. Foucault had a profound influence on Celati. Foucault's L'archeologie du savoir (1969) informs the discussion within Ali Babà (see also Calvino's essay Lo sguardo dell'archeologo, initially written for the journal Barenghi and Belpoliti 1998) while Surveiller et punir (1975) is a key text for Alice disambientata. The Foucauldian influences on Celati fall beyond the remit of this chapter; suffice it to mention here some other moments in which Foucault's thought is clearly behind Celati's considerations. His influence is in fact even more evident if one considers that, in the first version of Finzioni occidentali (200la), Celati had in mind to include a study on madness involving Jonathan Swift, Erasmus of Rotterdam, and Foucault (the title was meant to be L'ospedale degli incurabili, previously published in the journal Il Caffe; see Ronchi Stefanati 2017). The preface to the third edition of Finzioni occidentali confirms the role of Foucault in Celati's works and career, and marks the difference between the two authors. Celati mentions here his meeting with Foucault and the ambivalent feelings of admiration and repulsion towards a man whom he saw both as extraordinary and controversial:

Ricordo anche l'effetto che ha avuto su di me un seminario con Michel Foucault a Ithaca (il paesino dove c'è la Cornell University), e Foucault stesso, i suoi atteggiamenti, la sua incomparabile eloquenza, la sua straordinaria intelligenza, traviate da una velenosità che trovavo insopportabile. Dopo quel seminario ho deciso che non ne potevo più di agonismi intellettuali, non credevo più così ciecamente all'intelligenza, oppure soltanto non era la mia vocazione. (Celati 2001a, p. XII)

I believe these references illustrate the deep influence that radical psychiatry and the debate on madness had on Celati's work, and how the discussion on institutional power and in particular the re-thinking of the mental asylum contributed to the shaping of Celati's writings in the 1960s and 1970s. 


\subsection{The Political Dimension of the Bagarre: Artaud, Bakhtin, Céline}

In his essays from the 1970s, particularly "Su Beckett, l'interpolazione e il gag" (Celati 2001c) and "Il corpo comico nello spazio" (Celati 1976b), Celati theorizes the rationale and origins of the main feature of his works in the 1970s, namely the attempt at recreating comical effects of slapstick movies in written form. Celati explains that he aimed to create an effect of bagarre, which he linked to Artaud's plague effect. Artaud saw in the plague a metaphor for his notion of theatre. According to Artaud, theatre should be like the plague: a moment of total crisis where all certainties collapse and nothing remains but death or extreme purification (Artaud 1938). Similarly, Celati saw in the bagarre a therapeutic moment and, above all, a moment of anarchy and the absence of power. In order to better explain what he meant by the concept of bagarre, Celati also mentioned the Bakhtinian carnival (Bakhtin 1984) as a form of anarchy, where the political and social order ends and no new order replaces it (Celati 1976b): Bakhtin described the carnivalesque as the overturning of social hierarchies during the carnival, especially at the time of the Renaissance. Hierarchies of everyday life were suspended and replaced by subjects who were normally marginalized. This newly established order is not, however, to be maintained, as one would expect in a revolution, when rising powers take the place of an ancient regime. In Bakhtin's theory, the carnival's peak was, in fact, the crowning-decrowning ritual, where the new power immediately collapses, expressing the instability and vacuity of all power relations as well as all ideologies and systems of thought. Celati stresses this concept in "Dai giganti buffoni alla coscienza infelice" (Celati 2001d), in which he states: "nelle 'Feste dei folli,' il re incoronato era un pazzo, il che equivaleva a uno 'scoronamento' parodico del re o dell'autorità ufficiale; ma a sua volta il pazzo era scoronato con risate o lancio di ortaggi" (Celati 2001 d, p. 102). Belpoliti highlights the political dimension of the carnival and he uses it to read the 1977 student movement in Bologna, in which Celati had a fundamental role, together with the historian Piero Camporesi, who worked on the carnival in the same period (Camporesi 1975; Belpoliti 2001).

In "Dai giganti buffoni alla coscienza infelice," immediately after referring to the topic of folly in the Renaissance ceremony of the Feast of Fools, Celati once again alludes to his readings on psychiatry, particularly to the Schreber case. This confirms that Celati considers "madness" as a 
privileged perspective from which to analyze contemporary society. In this essay, Celati expounds on the social dimensions of the history of laughter: "[una] storia d'un rituale che si lega sempre all'ordinamento sociale, all'amministrazione degli spazi e dei corpi" (Celati 200ld, p. 55). By stressing the subversive nature of laughter in history, Celati reveals his own take on comedy, especially on its political value: the history of laughter is a "storia di proscrizioni compiute dalla cultura delle classi alte, contro un'attitudine alla parodia generalizzata che mal si concilia con il sapere assertivo e teologico" (Celati $2001 \mathrm{~d}$, p. 56). In the same essay, Celati significantly mentions Céline as the main example of a modern approach to folly through humor, satire, and caricature, of which Rabelais is the main ancestor.

Sembra che siano i relitti di antiche metafisiche che informano il delirio dei folli psicotici; come nel delirio del presidente Schreber [...] Forse esiste un modello nevrotico che funge da norma nella nostra cultura [...] Il nevrotico è l'uomo contro se stesso, che è invaso da fantasmi nella misura in cui si sente diverso dagli altri; ed è l'uomo critico per eccellenza, il decodificatore di segni ormai disgiunti dai sintomi, con cui coltiva la propria infelicità. Perciò il nevrotico ritiene i fantasmi nella mente, ma rifugge con orrore dalle gigantesche cosmologie della psicosi [...] Forse non è un caso se l'unico tipo di comicità moderna in cui emerge fortissimo questo delirio persecutorio, sia quella di chi, come L. F. Céline, ritrova in Rabelais il più sicuro antenato. (Celati 2001d, p. 107)

Madness and comedy are inextricably linked in Celati's thought, and the comedic style seems to him the most appropriate way to describe madness in all its facets without silencing the voices of the insane and speaking on their behalf. Bagarre and folly also appear to be, in Celati's view, two parts of an anarchic rebellion against a system of power and order imposed by violent and hierarchical institutions throughout history.

\subsection{A New Reading of Comiche}

Through Comiche, Celati gives a representation of the psychoses of the patients and the violent environment of the mental hospital, and, at the same time, he parodies life in the mental hospital in all its aspects, undermining the institution of the asylum. As I have previously mentioned, Celati's main tool to achieve a parodic effect is the use of language that he 
learnt from the inmate's notebooks. This enables him to recreate comical situations, much like the bagarre in silent films, which Celati sees as a persistent subversion of all hierarchies and values.

Comiche is, in fact, set in an oneiric mental hospital, which sometimes resembles a holiday camp by the sea, and sometimes a school. The superimposition of these places allows Celati to merge three different spaces of constraint and control (the holiday camp is itself depicted as an open-air prison rather than a place of rest or amusement: even by the sea, inmates are still subject to prohibitions, orders, and restrictions). The original title of the novel was actually Comiche al mare. In addition, Celati rewrote Comiche in 1972 and 1973, more explicitly satirizing the school while downplaying references to madness and the asylum (Celati 2016a, pp. 131-72). The parody of the school is already present in the 1971 version, which is the object of my analysis: many characters are schoolteachers or professors ("il maestro elementare Bevilacqua," "l'altro maestro Mazzitelli," "il terzo maestro Macchia;" "il professor Biagini"), there is also a headmistress (Lavinia Ricci, "direttrice di scuole di magistero"), a school janitor ("il bidello Ramella"), and the narrator himself is often called "professore." All characters in Comiche seem to be stuck in a period immediately following the unification of Italy, and often refer to outdated political ideologies and events, creating an effect of estrangement in the reader and a comical situation: "io ho fatto l'Italia" (Celati 2016a, p. 15); "E molti confondevano la mente elevando grida stravolte del tipo: - viva il re. In varie lingue con risposta: - viva" (p. 20); "V'era anche chi gli gridava in risposta: - viva l'Italia libera. E a parte: - abbasso gli Austriaci” (p. 37). Comiche describes many inmates who consider themselves monarchists, while the narrator is accused of being an anarchist. This is in line with the notebook Celati used as his model, L'organo mazziniano dell'ospedale psichiatrico di Pesaro, which features a direct reference to one of the political and intellectual leaders of the Risorgimento, Giuseppe Mazzini. The temporal gap between the references made by patients and the time in which the novel is written and seems to be set contributes to a feeling of separation and detachment from reality.

Aspects of mental disorders and paranoia, such as violent outbursts, persecution complexes, delusions of (historical) grandeur, and confusion between dreams and reality emerge in the description of the characters. The narrator, Professor Aloysio, appears to be conscious of what he calls "my disease," as the following quotes demonstrate: "strascichi della malattia" (p. 66); "sono stato sempre malato" (p. 113); "Con $[. .$.$] pericolo di$ 
danni alla mia salute malferma né mai intieramente [sic] riacquistata" (p. 119). Throughout the novel, Aloysio writes in his notebook while other patients push him to tear it up, accusing him of being a spy. The persistent questions are: "hai diffuso? Hai sparlato?," and then comes the order: "strappa," and the threat: "pagherai" (p. 126). Comiche also describes the asylum as a place of punishment and coercion, where nurses and doctors chase patients and force them to take drugs in order to calm them down:

La dottoressa invece: - domani facciamo una puntura. Rispondevo: - ah questo poi no. Conseguenze del mio rifiuto [...] sono arrivati correndo in due tre apparentemente infermieri di ospedale chiamati per farmi puntura. Da me cacciati con grida acute e improperi poco piacevoli reagivano: - è agitato provvederemo. In ispecie un infermiere Somà che guida gli altri in simili attacchi come ho appreso mentre segnavo il suo nome sul quaderno. È uno violento che all'ospedale sputa in testa ai malati per disprezzo [...] il giardiniere Cardogna ha chiamato proprio questo Somà capace di agire con il nessun scrupolo dimostrato in altri tempi da certi che mi facevano uscire il sangue dalle vene. (p. 76)

Gli infermieri d'ospedale Somà Malservigi mi rincorrono per vialetti col fine di catturarmi farmi la puntura. Promettendo: - con questa puntura noi ti vacciniamo. E l'invito: - così diventi socievole e onesto. Io scappavo ovunque in risposta dico: - non sono mica matto $[\ldots]$ inseguendomi Somà Malservigi infermieri essi due si sono separati di vialetto. Per accerchiarmi nella caccia con siringa. (p. 113)

Like other institutions that appear in Celati's oeuvre, his depiction of the asylum in Comiche is dominated by absurd prohibitions and orders, often coming from the director Lavinia Ricci or from a mysterious night guard: "Essendo il Guardiano notturno vietava: - proibito stare sulla spiaggia di notte. Io però spiegavo [...]. E lui: - proibito stare sulla pineta di notte $[\ldots]$, nel cesso di notte è proibito" (p. 26). In a further passage, the protagonist is completely banned from the beach, where part of the action is set, and this time the prohibition comes from the inmates themselves:

Già che i fastidi qui sono cosa d'ogni momento. Nella casa come sulla spiaggia. Dove tra l'altro è proibito persino farsi vedere. Avendo qualcuno scritto sul retro delle cabine a grossi caratteri di vernice rossa: - VIETATO L'INGRESSO AI CANI E AL PROFESSORE. (p. 77) 
The asylum in Comiche shares several characteristics of the concentration camp, as described by Levi (1947; see also Gordon 2012), such as the loss of one's name: everyone calls the protagonist Professor Aloysio, but this is not his name, as he explains: "Donde viene l'usanza pessima di farmi chiamare Aloysio che vuole dire cioè senza camera fissa come uno spirito vagante" (Celati 2016a, p. 76). The use of forced nudity to humiliate patients and the lack of solidarity among inmates confirm this description of the asylum:

Il Bagnino e il Guardiano Notturno adesso minacciosi: - deve spogliarsi. Devo spogliarmi nudo. Dopo dicevano agitando una lunga frusta: - deve correre intorno. Devo correre intorno al tavolo. E perché io lo facessi mi colpivano ancora sulla mano insanguinata. (p. 55)

The inmates also mock and abuse each other. This increases the effect of paranoia and self-punishment inside the asylum/school/holiday camp:

Ma presto con stupore indescrivibile sul mio volto scorgo da basso Cardogna che con chi sa quale trucco butta in aria la mia cartella [...]. E lui inveiva: vuole farsi vaccinare? vuole farsi monarchizzare? sì? no? allora sta condannato. Sì? no? allora sta punito. (p. 78)

This ferocious description of the asylum as a concentration camp is framed within a comical situation, modeled on slapstick films. Celati reproduces scenes taken from silent comedy, such as chases and other gags, and also delivers the comic effect through the use of the experimental language inspired by the inmate's notebooks. There are several examples of this, such as the episode in which the influence of slapstick films is most evident, featuring elements from the final scene of Laurel and Hardy's You're Darn Tootin' (1928). In the film, an argument between the protagonists creates a bagarre that involves many other bystanders, and the scene ends with all of them in their underwear. Almost the same happens in Comiche, where the inmate Fantini uses the gardener Fioravanti's scissors to cut the other characters' belts:

Presi i forbicioni correva a me dietro per tagliarmi qualcosa. Nel momento stesso giungevano al galoppo veloce due indiani Sioux col Barbieri che insegue furibondo: - ve lo do io gli indiani. Siccome erano i suoi figli Salvino e Malvino mentre lui aveva cappello trafitto da una freccia. Fantini trovatolo sul proprio cammino osserva: - intralcia questo babbeo. E: - giù le braghe 
per punizione. Gli taglia la cintura. Calavano i calzoni del Barbieri subito. Procurando capitombolo al possessore. Aggravato da faccia battuta al suolo. Tre denti persi. Esulta Fantini annusando odore d'abuso. Risorge Barbieri idrofobo contro Fioravanti legittimo proprietario dei forbicioni: come hai osato servo? Preso l'annaffiatoio lo irrora. Replica Fioravanti: - adesso stai fresco tu. Preso un barattolo di vernice gli imbiancava la faccia [...]. Passa Barbieri biancato insegue Fioravanti per biancare. Portinaio Marani impensieri: - ma che succede qui? [...] Villeggiane Graziosi: - to' un fantasma. Fantini stralunato accorso: - non permetto non permetto. Credendo si parli di lui. Taglia cintura a Graziosi: - giù le braghe. (pp. 125-126)

In conclusion, I claim that the novel Comiche should be read as Celati's contribution to the debate on mental health in the 1960s and 1970s, and represents a strong critique of the asylum. The evidence of Celati's involvement in the debate on madness that was raging in the 1960s and 1970s can be found across his oeuvre, in the numerous references he makes to the leading figures in this debate (e.g. Laing, Basaglia, Derrida, Foucault, Deleuze and Guattari), and to the sociopolitical implications of the notion of mental illness. These are a natural development of Celati's initial interest in madness, which originated in his encounter with the philosopher Melandri and in his reading of Freud's masterpieces. Celati's contribution is shaped through an experimental language, inspired by that of an inmate in a mental hospital. Celati's language in Comiche recreates the comical device of the bagarre, which has the effect of undermining the institution of the asylum where the novel is set, both uncovering its violent institutional nature and parodying it. I have also highlighted the political dimension of Celati's idea of bagarre as it emerges in his references to Artaud and Bakhtin: bagarre is a situation of disorder similar to that of the plague and the carnival, namely a state in which no hierarchy or value can be imposed or is even possible. Through this experimental, subversive language and through the effect of the bagarre Celati can represent madness, giving voice to it in the first person rather than speaking on its behalf.

\section{Notes}

1. See also Calvino (2008).

2. Celati read all these texts, as his essays in Finzioni occidentali confirm (Celati 2001a). Celati's interest thus anticipates the translation and diffusion in Italy of most of these works. Wolfson is diagnosed with schizophrenia in his childhood and placed in a psychiatric hospital, where he undergoes violent 
treatments such as electroconvulsive therapy. His book is a tale of the refusal of his mother tongue and the development of a method of immediate translation of every sentence into a foreign language.

3. In his letters to the Einaudi editorial board, Celati mentions authors such as Consolo, Morante, and Sciascia as the most representative of Einaudi's publishing policy and the most opposite to his own idea of literature (Ronchi Stefanati 2017).

4. The seminar focused mainly on Lewis Carroll's Alice in Wonderland and Alice Through the Looking Glass, and Edward Lear's Book of Nonsense.

5. During the 1970s, Celati translated Céline's Guignol's Band (1944; Italian translation published with Einaudi in 1982), Entretiens avec le professeur $\Upsilon$ (1955; Einaudi 1971), and Le pont de Londres (1964; Einaudi 1971).

\section{REFERENCES}

Artaud, Antonin. 1938. Le théâtre et son double. Paris: Gallimard.

Bakhtin, Mikhail. 1984. Problems of Dostoevsky's Poetics. Trans. Caryl Emerson. Minnesota: University of Minnesota Press.

Barbolini, Michele. 2009. A passeggio con un rabdomante: Michele Barbolini intervista Gianni Celati. Zibaldoni e altre meraviglie, February 11. http:// www.zibaldoni.it/2009/02/11/celati/. Accessed 3 Aug 2018.

Barenghi, Mario, and Marco Belpoliti, eds. 1998. Riga 14. Ali Babà: Progetto di una rivista 1968-1972. Milan: Marcos y Marcos.

Basaglia, Franco, ed. 1968. L'istituzione negata: Rapporto da un ospedale psichiatrico. Turin: Einaudi.

Belpoliti, Marco. 2001. Settanta. Turin: Einaudi.

Caesar, Michael. 1986. Caratteri del comico nelle “Avventure di Guizzardi". Nuova Corrente 33: 33-46.

Calvino, Italo. 2008. Nota a "Comiche”. In Riga 28. Gianni Celati, ed. Marco Belpoliti and Marco Sironi, 168-169. Milan: Marcos y Marcos.

Camporesi, Piero. 1975. Carnevale, cuccagna e giuochi di villa. Studi e problemi di critica testuale 10: 57-97.

Celati, Gianni. 1971. Comiche. Turin: Einaudi.

1972. Le avventure di Guizzardi. Turin: Einaudi.

1976a. La banda dei sospiri. Turin: Einaudi.

- 1976b. Il corpo comico nello spazio. Il Verri 3: 22-32.

- 1976c. 'Gianni Celati to Guido Davico Bonino,' Autumn 1976. Giulio Einaudi Editore Archive.

-1978a. Lunario del paradiso. Turin: Einaudi.

, ed. 1978b. Alice disambientata: Materiali collettivi (su Alice) per un manuale di sopravvivenza. Milan: L'erba voglio. 
2001a. Finzioni occidentali: Fabulazione, comicità e scrittura. Turin: Einaudi.

- 2001b. Il bazar archeologico. In Celati, Gianni. Finzioni occidentali: Fabulazione, comicità e scrittura, 197-227. Turin: Einaudi.

- 2001c. Su Beckett, l'interpolazione e il gag. In Celati, Gianni. Finzioni occidentali: Fabulazione, comicità e scrittura, 165-194. Turin: Einaudi.

- 2001d. Dai giganti buffoni alla coscienza infelice. In Celati, Gianni. Finzioni occidentali: Fabulazione, comicità e scrittura, 53-110. Turin: Einaudi.

- 2007a. Alice. In Annisettanta: Il decennio lungo del secolo breve, ed. Marco Belpoliti, Gianni Canova, and Stefano Chiodi, 33-35. Milan: Skira.

$\longrightarrow$, ed. 2007b. Alice disambientata: Materiali collettivi (su Alice) per un manuale di sopravvivenza. Florence: Le lettere.

- 2016a. Comiche. In Celati, Gianni. Romanzi, cronache, racconti, 5-128. Milan: Mondadori.

- 2016b. Caro Calvino, non sono d'accordo: Celati's Letter to Italo Calvino. Doppiozero, February 15. http://www.doppiozero.com/materiali/ meridiano-celati/caro-calvino-non-sono-d-accordo. Accessed 13 Nov 2017.

Celati, Gianni, and Carlo Gajani. 2017. Animazioni e incantamenti: "Il chiodo in testa", "La bottega dei mimi" e altri testi sul teatro e sulle immagini. Rome: L'orma.

Céline, Louis-Ferdinand. 1944. Guignol's Band. Paris: Denoël.

- 1955. Entretiens avec le professeur $\Upsilon$. Paris: Gallimard.

- 1964. Le pont de Londres. Paris: Gallimard.

- 1982. Guignol's Band. Trans. Gianni Celati. Turin: Einaudi.

Deleuze, Gilles, and Félix Guattari. 1972. L'Anti-CEdipe: Capitalisme et schizophrénie. Paris: Minuit.

Derrida, Jacques. 1967. L'écriture et la différence. Paris: Seuil.

Ferrero, Ernesto. 2005. I migliori anni della nostra vita. Milan: Feltrinelli.

- 2008. Rhêmes o della felicità. Courmayeur: Liaison.

Foot, John. 2015. The Man Who Closed the Asylums: Franco Basaglia and the Revolution in Mental Health Care. London/New York: Verso.

Foucault, Michel. 1961. Folie et déraison: Histoire de la folie à l’âge classique. Paris: Librarie Plon.

- 1975. Surveiller et punir: Naissance de la prison. Paris: Gallimard.

Francioso, Monica. 2009. La forza della coerenza: La grammatica celatiana e l'Einaudi. In Letteratura come fantasticazione, ed. Laura Rorato and Marina Spunta, 291-303. New York/Lampeter: Edwin Mellen Press.

Freud, Sigmund. 1904. Zur Psychopathologie des Allagslebens. Berlin: S. Karger.

- 1905a. Der Witz und seine Beziehung zum Unbewussten. Leipzig/Wien: Franz Deuticke.

- 1905b. Drei Abhandlungen zur Sexualtheorie. Leipzig/Wien: Franz Deuticke. 
1911. Psychoanalytische Bemerkungen über einen autobiographisch beschriebenen Fall von Paranoia. In Jahrbuch für psychoanalytische und psychopathologische Forschungen, ed. Carl Gustav Jung and Sigmund Freud, 239-320. Leipzig/Wien: Franz Deuticke.

Goffman, Erving. 1961. Asylums: Essays on the Social Situation of Mental Patients and Other Inmates. New York: Anchor Books.

Gordon, Robert. 2012. The Holocaust in Italian Culture 1944-2010. Stanford: Stanford University Press.

Iacoli, Giulio. 2012. Atlante delle derive: Geografie da un'Emilia postmoderna. Gianni Celati e Pier Vittorio Tondelli. Reggio Emilia: Diabasis.

La Polla, Franco. 1972. Comiche letterarie e tecniche cinematografiche. Paragone letteratura 23: 94-98.

Laing, Ronald David. 1960. The Divided Self: An Existential Study in Sanity and Madness. London: Penguin.

Levi, Primo. 1947. Se questo è un uomo. Turin: De Silva.

Morgenthaler, Walter. 1921. Ein Geisteskranker als Künstler. Bern/Leipzig: Bircher.

Ottone, Giuseppe. 1972. Celati e le comiche. Italianistica: 221-222.

Palmieri, Nunzia. 2016. Cronologia. In Gianni Celati, romanzi, cronache, racconti, ed. Marco Belpoliti and Nunzia Palmieri, LXXV-CXXIV. Milan: Mondadori.

Righi, Andrea. 2011. Biopolitics and Social Change in Italy: From Gramsci to Pasolini to Negri. Basingstoke: Palgrave Macmillan.

Ronchi Stefanati, Michele. 2015. Dal cinema alla letteratura e ritorno: Il documentario nell'opera di Gianni Celati. In Lingue e linguaggi del cinema in Italia, ed. Marco Gargiulo, 357-379. Rome: Aracne.

- 2017. "Intonare lo strumento di un altro italiano": Il carteggio tra Gianni Celati e l'Einaudi (1966-1979). Italian Studies 72 (3): 309-322.

Scabia, Giuliano. 2011. Marco Cavallo: Da un ospedale psichiatrico la vera storia che ha cambiato il modo di essere del teatro e della cura. Meran: Alphabeta Verlag.

Schreber, Daniel Paul. 1903. Denkwürdigkeiten eines Nervenkranken. Leipzig: Mutze.

West, Rebecca. 2000. Gianni Celati: The Craft of Everyday Storytelling. Toronto: University of Toronto Press.

Wolfson, Louis. 1970. Le schizo et les langues. Paris: Gallimard. 


\title{
Mental Social, and Visual Alienation in D’Alessandro's Photography
}

\author{
Alvise Sforza Tarabochia
}

In this chapter I turn my attention to photography, and in particular to the first of several photobooks that accompanied the process of the reform of psychiatric health care in the 1960s and 1970s: Luciano D'Alessandro's 1969 Gli esclusi (D'Alessandro and Piro 1969). ${ }^{1}$ According to Sekula, a photograph is an "incomplete' utterance, a message that depends on some external matrix of conditions and presuppositions for its readability" (Sekula 1982, p. 85). If the "meaning of any photographic message is necessarily context-determined" (Sekula 1982, p. 85), the aim of this chapter is to establish the philosophical, sociopolitical and cultural context within which D'Alessandro's photographic message becomes readable. The "readability context" I will unravel is determined by the notions developed by those psychiatrists who were fighting against the regressive system of Italian psychiatry, chief among them Franco Basaglia.

Luciano D'Alessandro (1933-2016) was a Neapolitan photographer who dedicated his life to photojournalism, working with major Italian and international magazines and newspapers, such as L'Espresso, Europeo,

\footnotetext{
A. S. Tarabochia $(\bowtie)$

Department of Modern Languages, School of European Culture and Languages, University of Kent, Canterbury, UK

e-mail: A.Sforza-Tarabochia@kent.ac.uk

(C) The Author(s) 2019

A. Diazzi, A. S. Tarabochia (eds.), The Years of Alienation in Italy, https://doi.org/10.1007/978-3-030-15150-8_11
} 
Corriere della Sera, Life, Stern, and Le Monde. D'Alessandro immediately accepted when Sergio Piro, director of the Materdomini mental asylum in Nocera Superiore (Salerno), invited him and film director Riccardo Napolitano to document the abysmal conditions in the institution. This was part of Piro's anti-institutional strategy, similar to that of Basaglia in Gorizia with Berengo Gardin and Cerati. ${ }^{2}$ Piro was in fact a phenomenological psychiatrist and an outspoken supporter of Basaglia's reformism. He was second only to Basaglia in introducing the therapeutic community into Italy.

An initial selection of twenty-one of D'Alessandro's photographs was published in 1967, in the 117th issue of Popular Photography Italiana, under the title "Il mondo degli esclusi" (D'Alessandro 1967). The images were accompanied by a short presentation by D'Alessandro and an article by Piro, entitled "Fotografia e alienità" (Piro 1967). In 1969, some days after Piro was fired from his post because of his reformist impetus, Il diaframma published the photobook Gli esclusi: Fotoreportage da un'istituzione totale, consisting of ninety-eight pictures by D'Alessandro, accompanied by a longer introduction by Piro.

D'Alessandro's photographic work in the Materdomini has so far received limited scholarly attention, overshadowed by the (arguably) more impactful photobook of the same year, Morire di classe, commissioned and edited by Franco Basaglia and his wife Franca Ongaro. Gli esclusi was well received by critics. Grassi $(1969$, p. 3), in the newspaper Roma, sees in it the sign that "la contestazione è giunta nel campo psichiatrico [...] con estrema intelligenza e raffinatezza" and Stefanile (1969, p. 3), in Il Mattino, regards D'Alessandro's first photobook as a "grossa conquista, da salutare con rispetto e con amore." According to Cesareo (1981, p. 29), "le immagini elaborate da Luciano D'Alessandro [...] sono strumenti di indagine dell'istituzione, strumenti di denuncia e di analisi, di mobilitazione e di lotta." Manzoli (2004, p. 4) maintains that D'Alessandro, and other photographers, such as Berengo Gardin and Cerati, "entrano negli ospedali psichiatrici per documentarne l'orrore." Schinaia (2004, p. 467) sees in Gli esclusi the shift from the "non detto o [...] dire scandalistico" of the previous (rare) reportage on asylums, to the "tentativo di raccontare delle storie e di avvicinare emotivamente l'“altro';" Russo (2011, p. 314) counts it among the "fotoreportage umanitar[i]" of the 1960s-1970s in Italy; D'Autilia (2012, p. 342) borrows Schinaia's words in regarding Gli esclusi as part of a trend "estetico-emotivo" in the representation of psychiatric matters. Babini (2009, pp. 252-254) includes Gli esclusi in her history 
of Italian asylums. Carli (2014, p. 106) notes how its images "esplorano e-al tempo stesso-accusano." Foot (2015, pp. 29-30) mentions D'Alessandro's photos only in passing, as coinitiator, with Morive di classe, of the wave of "asylum photography." Forgacs (2014) analyzes Gli esclusi in a section of the chapter "Asylums," tellingly named "Limits of vision." He claims that photography is limited in its "capacity to record any kind of complex social information" (Forgacs 2014, p. 233) and that photos in Gli esclusi, as much as those in Morive di classe, are taken by photographers "from the outside [who are] perhaps inevitably, intrusive" (Forgacs 2014 , p. 239).

Despite numerous scholars having mentioned D'Alessandro's photos, at least in passing, no one to date has highlighted the individuality of D'Alessandro's Gli esclusi: all scholars who mention Gli esclusi count it together with Morive di classe, certainly because both were published in the same year. In this chapter I will analyze Gli esclusi as an independent cultural product, framing it within the dominant theoretical strains that I believe influenced it. Among the most prominent notions there is certainly that of alienation. Through Sartre, existentialism, and the work of phenomenological/existentialist psychiatrists, Basaglia developed a stance that recognized both the ill-effects of social alienation and its inevitability in terms of development of the individual self. Such a conception feeds into the photographic language of the reform, as I will show. To this extent, in the next section I will discuss the notion of alienation as it was received and elaborated by Italian reformist phenomenological psychiatrists, in particular Franco Basaglia.

\subsection{Alienation According to Basaglia}

Basaglia's notion of alienation is very much indebted to existentialism, especially to Sartre, whose complexities cannot be untangled in this chapter. I will limit my analysis to a brief outline of Sartre's notion of alienation as he sets it out in Being and Nothingness. According to Sartre (1978, p. 263) the "alienation of myself" is "the act of being-looked-at"; it is the look of the Other that "alienates [my possibilities] from me": "I grasp the Other's look at the very center of my act as the solidification and alienation of my own possibilities." Alienation is also a fall, in that, continues Sartre (1978, pp. 274-275), "my being for-others is a fall through absolute emptiness toward objectivity. And since this fall is an alienation, I can not make myself be for myself as an object for in no case can I ever alienate 
myself from myself." Alienation is at the core of the experience of being oneself; it is a constitutional and constitutive alienation in the Other; it corresponds to being in a relationship with the Other, an object of the other's look. For this very reason alienation is reciprocal, in that as much as I am defined by the look of the Other, which alienates me, I am the Other to someone else, and my look causes the very same alienation I undergo to others. "By the very fact of my own self-assertion I constitute him [the Other] as an object and as an instrument, and I cause him to experience that same alienation which he must now assume" (Sartre 1978, p. 410). Ultimately, according to Sartre, alienation is unavoidable:

The very meaning of our free choice is to cause a situation to arise which expresses this choice, a situation the essential characteristic of which is to be alienated; that is, to exist as a form in itself for the Other. We can not escape this alienation since it would be absurd even to think of existing otherwise than in situation. (Sartre 1978, p. 526)

While such a "reciprocal" alienation is unavoidable according to Sartre, according to Basaglia it is where the encounter between the self and the Other, the establishment of a relationship, can become pathological. In "Corpo, sguardo, silenzio," Basaglia (1965a) posits that there are two modes of being in a relationship with others. He calls them alterità (alterity/being other) and alienità ("alienity" / being alien). In a state of alter$i t a$, the subject accepts the presence of the other and its necessity: there is no self, other than what others see. Otherwise, one could attempt to remove oneself completely from being exposed to the determining presence of the other. In this case, one would fall into a state of alienità. According to Basaglia, this indeed echoes Sartre:

I thereby recognize and affirm not only the Other but the existence of my Self-for-others. Indeed this is because I can not not-be the Other unless I assume my being-as-object for the Other. The disappearance of the alienated Me would involve the disappearance of the Other through the collapse of Myself. [...] But as I choose myself as a tearing away from the Other, I assume and recognize as mine this alienated Me. (Sartre 1978, p. 285)

Reciprocal alienation is played out on the body. According to Basaglia (1965a, p. 304), "è qui, nel mio costituirmi come persona che il mio corpoaperto e vulnerabile - si staglia in mezzo agli altri e alle cose." The body, 
"thrown" in a Heideggerian sense into the Other, at the mercy of its look, is the subject's "facticity," everyone's quality of being a factual existence. There must however be an "intervallo," an "interval," a "gap"-made of physical space and silence-between bodies, for them to "salvaguardare ciascuno la propria intimità dall'altro” (Basaglia 1965a, p. 307). This interval enables me to "trovare il tempo ed il luogo dove poter accettare il mio corpo visto dagli altri, prima di accettarmi nel rapporto con gli altri" and gives me the "possibilità di avere sull'altro lo stesso potere che egli ha su di me" (Basaglia 1965a, p. 305). The state of alienità is the "perdita dell'intervallo dove appropriarmi del mio stesso corpo [...] l'alienità è il rifiuto della propria fattità" (Basaglia 1965a, p. 304). I have shown elsewhere (Sforza Tarabochia 2014) how this mechanics of unavoidable alienation/establishment of a gap in Basaglia maps well onto Lacan's theory of the ontogenesis of the self (as caught up in the pair alienation/separation), despite Basaglia's aversion to psychoanalysis.

For the purpose of this chapter, it suffices to note that according to Basaglia alterità corresponds to the non-pathological mode of existence of every human being-we could venture to call it, with due caution, “subjectivity." "L’uomo," writes Basaglia (1965a, p. 305),

Non può attuare questo atto di riflessione su di sé se non attraverso lo sguardo altrui: è lo sguardo d'altri [...] che mi rende cosciente di me perché solo attraverso lo sguardo d'altri io posso essere la mia oggettività, avvertendo contemporaneamente la soggettività dell'altro che mi determina $\mathrm{e}$ mi domina.

It is only in maintaining a distance from the other that I can acknowledge myself as, in turn, other. This intervallo, this gap between the other and myself, enables me to establish the unavoidable relationship with the other: this is a state of alterità. Yet this distance cannot be a complete fracture with otherness, because that would cause a state of alienità: by refusing to be in a relationship with the other (that paradoxically I would refuse precisely to safeguard to the utmost my distance from the other, to make it insurmountable, to protect myself from the other), I would lose the intervallo and fade into the other. According to Basaglia (1965a, p. 309), "nel momento in cui l'uomo perde l'occasione di vedersi, di accettarsi nella propria fattità attraverso l'oggettivazione datagli dalla presenza dell'altro [...] l'uomo perde la propria alterità e si aliena." 
When in his anti-institutional "manifesto" Basaglia (1964, p. 267) defines the asylum as a "luogo di istituzionalizzazione e di alienazione indotta," I believe he is referring to the condition of alienità he develops in the same years (1964-1965): alienità is not, or at least not only, part of the pathogenesis of a mental disorder, it is caused by the institution itself that forces the inmates to lose the intervallo, the empty space and silence, which enables the subject to establish a reciprocally and not univocally alienating relationship with the other. In the psychiatric institution, inpatients lose the gap, "dove poter appropriarmi del mio stesso corpo, abbandonato in una promiscuità in cui l'altro mi urge senza tregua, da tutti i lati e mi invade" (Basaglia 1965a, p. 304).

Hence, alienation in Basaglia describes the pathological outcome of the constitutional and constitutive encounter with the other. While on the one hand in the 1965 paper "Corpo, sguardo, silenzio" he regards it as a pathological process that is at the basis of mental disorders, in his 1964 antiinstitutional manifesto he specifies that it is the institution of the asylum that causes alienation in its inmates. In this double understanding of the notion, the social and psychological acceptations of alienation effectively converge. Not incidentally, this bridges Sartre's analysis of alienation with Foucault's theory of power, another pivotal source of influence for Basaglia. The institutional power wielded in the psychiatric hospital is not a form of sovereign power, an external imposition alien to the subject. Power does not come as an external imposition. Institutional power exploits the very psychological structures of subjectivity, it is exerted not only at the level of the bodies but also of their most intimate thoughts. In other words, it is a form of disciplinary power (see Foucault 2008).

\subsection{Mental Alienation: "Il mondo Degli esclusi”}

The first visual representation of such a multilayered conception of alienation in psychiatry emerges in D'Alessandro's initial selection of images in "Il mondo degli esclusi." More than half (twelve) of the pictures published in Popular Photography Italiana are details of inmates' hands. The remaining nine images are portraits of the inmates: two are sleeping, three are in a straitjacket, two are close-up portraits, two show groups of inmates in the courtyard of the asylum.

In his presentation, the photographer remarks that he accounts his work in the Materdomini asylum one of his most interesting works of reportage "diretti tutti a scavare nella realtà dell'uomo, colto nel suo 
lavoro, nel rapporto con gli altri, insomma nelle situazioni relazionali che nascono dal suo trovarsi, volente o nolente, in questo mondo" (D'Alessandro 1967, p. 52). Significantly, D'Alessandro seems to be pointing to a visual exploration of Heidegger's "being-in-the-world," the constitutional state of being of every person that signifies the unavoidability of always being in a situation, in a place, in a relationship with others. His initial work, however, was confused, as it produced "un materiale informe che non riusciva a prendere vita a sé, ad esprimersi attraverso un discorso preciso" (D'Alessandro 1967, p. 53). The key, according to D'Alessandro, was to understand his own work as a visual exploration of the "solitudine del malato mentale, rispetto al suo mondo di provenienza, rispetto agli altri, una solitudine che nasce dalla malattia" (D'Alessandro 1967 , p. 54). The initial purpose of these pictures was thus to represent an existential solitude that he believed to be the product of the mental disorder itself-mental alienation. Already in his first theoretical writings in 1953, Basaglia (1953, p. 57) refers to the existential condition of those suffering from a mental disorder as a rimpicciolimento, a "shrinking" of the existential structure. In discussing the case of a patient, Basaglia (1953, p. 57) says that "il mondo esterno veniva dunque a convergere su di lei e a comprimerla così da impedirle di espandersi e di esplicarsi $[. .$.$] nel tenta-$ tivo di liberarsi dalle strettoie del processo di 'rimpicciolimento' finisce invece con il precipitare più rapidamente in esso." In the 1966 paper "Ideologia del corpo come espressività nevrotica," Basaglia (1966, p. 353) repeats, borrowing the words of the phenomenological psychiatrist Haffner, that in those suffering from mental disorders the "esistenza di una facciata monolitica [...] è espressione di un rimpicciolimento della struttura interiore tale da non poter sostenere giudizi, confronti e contestazioni." According to Basaglia, in order to defend oneself from the determining presence of the other, that is to say instead of sustaining one's own alterità, those suffering from a mental disorder fall into a state of alienità: the other is no longer the mirror in which subjects can find themselves, as it were.

D'Alessandro's initial selection of pictures therefore focuses on individual solitude, what he regards as the mental alienation caused by the disorder itself. The predominance of details of hands, one of which occupies the entire title page of the article, while the remaining eleven are grouped together in the following two pages (pp. 52-53), is very telling. The camera dwells on the intimate dimension of silent gestures: in no picture are there hands that belong to different people. The hands portrayed carry 
food, play with a scrap of paper, rub each other, are joined in prayer, or are brought to the face perhaps to emphasize an emotion. They are not portrayed in actions of exchange; they don't seem to reach out for the other. In the article that accompanies the pictures, Piro affirms that "le mani $[\ldots]$ sono un fattore importante spiritualmente perché permettono di manipolare il mondo" (Piro 1967, p. 88). D'Alessandro, however, is portraying the hands of those suffering from a mental disorder: "le mani dell'uomo che vive la sua alienità sono mani abbandonate, inerti, contratte, violentemente aduncate $[\ldots]$ esse parlano, nel loro modo occulto, il linguaggio della solitudine, dell'isolamento, dell'abbandono, dell'impotenza a vivere, dell'incertezza, della furia, della macerazione, della resa totale" (Piro 1967, p. 88). D'Alessandro's selection of pictures indeed can be said to be an exploration into "il mondo degli esclusi," as he understood it. He presents it as a shrunken, impoverished, world and he symbolizes it through intimate portraits of hands, captured in non-expressive, at times meaningless, gestures. The remaining pictures capture this shrunken world more literally, in the form of idle moments spent on the floor of a run-down courtyard, in a straitjacket, in despair, or contemplating the emptiness. The contextual origins of this exclusion and of the shrinking of the world are omitted from the visual datum, however, and D'Alessandro's commentary points in the same direction: the solitude he portrayed is born of the mental disorder.

If there is a visual recognition of the institutional context in which the solitude of the mentally ill is isolated it is rather limited, especially when compared with the famous photobook that D'Alessandro published in 1969.

\subsection{Social Alienation: Gli esclusi}

Two years later, in 1969, D'Alessandro published a larger selection of pictures (ninety-eight) taken during his work in the Materdomini, including most of the twenty-one published in Popular Photography Italiana. Gli esclusi: Fotoreportage da un'istituzione totale, published by Il diaframma, with an introduction by Piro, is the first Italian photobook on the asylum and D'Alessandro's first photobook. The title already points in a different direction compared to the article: it is no longer the "shrunken" world of the excluded that will be portrayed, but it will be the excluded themselves. The subtitle adds that this is a photoreportage from a "total institution," a concept and term coined by the sociologist Goffman, which gained cur- 
rency in discussions on mental asylums in Italy during the reform. "Total institutions" are, according to Goffman, all those places, such as schools, prisons, and hospitals, in which the totality of the lives of those who reside in them is regulated and dictated by institutional rules (Goffman 1961). Chief among these total institutions is the asylum. Basaglia himself repeatedly referred to the asylum as a "total institution" (not for the first nor for the last time) in his introduction to the Italian translation of Goffman's Asylums, published by Einaudi in 1975 (Basaglia 1975). The subject of Gli esclusi is thus no longer the shrunken world of those suffering from a mental alienation, but the excluded themselves, with the implication that their existences have been shrunk into the asylum by society and the institution. "Il lavoro fotografico gli è cambiato fra le mani"-comments Babini (2009, p. 253)—“ora l'unica strada che gli si apre davanti è quella della denuncia in termini sociali, politici e anche umani."

The photobook not only includes a wider selection of pictures, but it also provides a visual exploration of a wider conception of alienation that brings it even closer to Basaglia's. While the driving theme is still that of alienation understood as existential solitude, detachment from the other, the underpinning message is different and seems to indicate more clearly an external point of origin for this solitude. In "Il mondo degli esclusi," D'Alessandro speaks of an alienation caused by the mental disorder. In the photobook, on the other hand, a more visibly political take emerges, in parallel to the blossoming of the reformist movement in Italian psychiatry in the momentous final years of the 1960s. Piro, in his introduction to Gli esclusi, acknowledges that, while D'Alessandro had initially attributed the solitude portrayed to mental alienation, the solitude was not, in fact "il risultato di una malattia, essa era la testimonianza diretta della violenza" (D'Alessandro and Piro 1969, no page). According to Piro, psychiatrists were the perpetrators of this violence, the cause of the alienation of those suffering from a mental disorder and he counted himself amongst them: "io ero lì, paternalisticamente buono e mistificatamente comprensivo, quale strumento di fatto di quella violenza $[\ldots]$ costantemente impegnato in un ruolo che implicava il potere, la sopraffazione, la violenza, l'autoritarismo. Allora la solitudine che Luciano mi mostrava era l'effetto della mia violenza" (D'Alessandro and Piro 1969, no page). Regardless of the intentions of the photographer, Piro sees in D'Alessandro's pictures a well-deserved "dito puntato dell'accusatore."

Some kind of reform, however, was already underway in several psychiatric hospitals, as Foot $(2015$, p. 24$)$ argues in order to contend that the 
other famous photobook of the reform, Morive di classe, was "a little bit of a fake product" in that the photos did not take into account these ongoing changes. Gli esclusi likewise portrays the state of decay of the institution and the abandonment of the patients rather than the reforms. Piro was aware of this_- "potrà qualcuno obiettare che dal 1965 ad oggi in molti Ospedali psichiatrici [...] le condizioni dei malati mentali sono migliorate" (D'Alessandro and Piro 1969, no page) - and contended that on the one hand "negli Ospedali più arretrati le cose non sono cambiate" while, on the other, even if they had changed, "la storia della solitudine rimarrebbe identica." Piro concludes that "la violenza rimane e le immagini sono sostanzialmente attuali" (D'Alessandro and Piro 1969, no page). Whether as a place of violence and constraint or as a "gabbia d'oro," "dove tutti i bisogni sono soddisfatti," the psychiatric hospital remains a "luogo di alienazione" (Basaglia 1964, p. 267), perhaps even more so as a "golden cage" in that "il nuovo clima ospedaliero può produrre ora $[\ldots]$ uno stato di soggezione ancora più alienante, perché frammisto a sentimenti di dedizione" (Basaglia 1964, p. 267).

It is not therefore the alienation of the mental disorder that emerges in D'Alessandro's pictures in Gli esclusi, but the alienation that the institution produces. "Il vuoto è stato pienamente colto nelle immagini," continues Piro, "ma questo non è il vuoto della malattia come ineluttabile condanna biologica, è invece il vuoto che l'apatia, l'inerzia e l'abbandono hanno creato in coloro che sono esclusi da qualunque movimento e da qualunque dinamica" (D'Alessandro and Piro 1969, no page). This of course does not exclude the effects of the mental disorder itself. The violence of the institution, its coercion, stacks up with the effects of mental alienation, continues Piro: "se già lo spazio dell'uomo era ristretto dalla sua alienità, esso viene ulteriormente ristretto dalla violenza e dall'abbandono" (D'Alessandro and Piro 1969, no page). Piro is echoing Basaglia here. According to Basaglia (1965b, p. 271) mental disorders and effects of coercion overlap in "institutionalization," understood as the "complesso di 'danni' derivati da un lungo soggiorno coatto quale quello nell'ospedale psichiatrico.” Institutionalization is

Un comportamento legato al processo di "rimpicciolimento" dell'io cui il malato mentale è sottoposto dal momento del suo ingresso nell'asilo. Tale processo si sovrapporrebbe, in soggetti già psichicamente fragili, all'iniziale malattia mentale così da costruirne un complesso sindromico che spesso può venir confuso coi sintomi della malattia stessa: inibizioni, apatia, perdita di iniziativa, di interessi, ecc. (Basaglia 1965b, p. 271) 
The psychiatric institution therefore imposes a further alienation on psychiatric patients, turning them into inmates. However, continues Piro, it would be incorrect to see in D'Alessandro's pictures only the solitude caused by the mental disorder, just as it would be incorrect to see in them only the alienation caused by the institution. Neither is independent from the other, and "in fondo è la solitudine dell'uomo (la grande solitudine ontologica) quella che [D'Alessandro] scopriva." It is an ontological solitude that is exploited and brought to its extremes in the psychiatric hospital, as an effect "della violenza, dell'esclusione, dell'abbandono," which originate in the family and in society and that "l'Ospedale $[\ldots]$ prolunga $e$ [...] rende definitiva."

With these considerations we have come full circle in the discussion of the notion of alienation: the shrinking of existence that the institution imposes on the psychiatric patient is nothing but the symptom of the shrinking and weakening of society itself. According to Basaglia (1965c, p. 291), "questa necessità di isolare il malato di mente, di scrollarselo di dosso, è espressione dello stato di debolezza e di rimpicciolimento di una società che tende ad eliminare tutto ciò che turba la sua espressione senza tenere conto della parte di responsabilità che in questi processi essa pure gioca."

The constitutional and constitutive alienation that characterizes the very ontogenesis of the self does not develop logically and ontologically into a negotiated alterità and the subject suffering from a mental disorder falls into a state of alienità, an alienation which finds no distance from the other, no space for subjectivation. The family, society, and eventually the psychiatric institution latch onto this mechanism and reduce the intervallo even further, making alterità more difficult to achieve and precipitating the subject further into a state of alienation. But this is nothing more than a symptom of a society that is unable itself to achieve alterità. It is a symptom of a society that fears difference and, instead of negotiating a distance from it, it attempts to tear away from it by alienating it into the asylum, at the same time alienating itself.

\subsubsection{Hands}

These considerations find visual representation in Gli esclusi. The photobook can be divided into two sections of similar length: images of men and images of women. Each section begins with an "establishing shot:" a twopage spread wide angle photo of the courtyard. The male establishing shot 
(pp. 2-3) is followed by fifty-two pages of images of male inmates. The female establishing shot (pp. 56-57) is followed by forty-eight pages. As was already clear in "Il mondo degli esclusi," D'Alessandro is a keen observer of hand gestures. Of the ninety-eight pictures in Gli esclusi, twenty-seven are details of hands, eighteen are portraits that feature hand gestures prominently, and nine are portraits in which the subjects seem to hide their hands on purpose. Piro indeed notices that "D'Alessandro fa parlare le mani," interpreting the inmates' language since "se la comunicazione è altrimenti bloccata, le mani parleranno, quasi contro il desiderio dell'uomo, e racconteranno la storia della violenza, dell'esclusione, della discriminazione, della segregazione e dei soprusi." Hands and their gestures are not captured as potential symptoms of mental disorders, "quali segni convenzionali di una mostruosità," but they will be, according to Piro, "illuminati dal loro più generale significato, nell'insieme della loro completezza espressiva" (D'Alessandro and Piro 1969, no page).

\subsubsection{Idleness}

The dominant feeling that emerges from D'Alessandro's selection of photographs is one of idleness. Hands and gestures are often used to convey this feeling. The very first image after Piro's introduction is a vertical shot of a courtyard wall. The whole left third of the image is occupied by an inmate standing, slightly out of focus. The remaining two-thirds of the frame are occupied by the wall. The top right quadrant features an out-offocus inmate standing; the viewer's eyes are led to him by the vanishing point of the wall. The inmate in the foreground has his eyes closed, head tilted upwards, possibly basking in the sun. The arms meet each other at the hands. The left hand holds the back of the right hand. It is a peaceful posture, but also a very inert, passive one. The photo on p. 5 features an inmate sitting on the floor of the courtyard, ankles locked, legs stretched, looking at his shoes. He keeps his hands between his thighs in a humble, self-restraining, posture. The image does not suggest serenity but inertia, idleness, boredom. In the background of the image, where the lead lines of the tiles direct the viewer's gaze, other inmates lie on the floor, idle. A very powerful sequence starts at p. 17. The picture is a close-up, plongeé, of a crouched inmate in the courtyard. His left hand, slightly motion-blurred, reaches out for something on the floor. The following pages reveal that he was reaching for a used matchstick. The detail of his hand taking the matchstick at p. 18, is followed by two smaller pictures featuring the detail of 
both hands handling the stick; pp. 20 and 21 feature a spread with the detail of both hands playing with the matchstick, which is concealed by the fingers. These images insist on a trivial gesture: by proposing a sequence of very similar pictures it seems to mimic a film reel, giving the viewer a sequential sense of movement. The movements, however, are minor: they describe an unimportant, unassuming and purposeless activity that suggests the boredom, idleness, and ultimately the meaninglessness of time.

In the following pages other details of hand gestures and inmates' postures give similar impressions. An inmate holds his hands in his trousers, in a very asexual posture, seemingly to warm them up (pp. 23 and 24-25); on p. 28 an inmate looks at his hands; on the same page the picture is followed by two close-ups of hands rubbing. The spread on pp. 30-31 details two wrinkled hands handling a crumpled piece of newspaper, establishing strong visual similes (wrinkled-crumpled; old-wasteful; abandonedthrown), almost a visual iteration of the Heideggerian thrownness that characterizes all human existences, but affects, redoubled, those abandoned in the asylum.

D'Alessandro conveys idleness not only through details of hands. Already the two establishing shots portray inmates either sitting or standing, but not engaged in any activity. Most other group or individual portraits feature idle subjects. The male establishing shot is followed by seven pages of idle subjects, interrupted by a possible conversation on p. 11 and by the images of the patient writing on the wall, discussed later. The female establishing shot is followed by nine pages of idle subjects, interrupted at p. 67 by the detail of a hand with a piece of bread.

\subsubsection{Interaction and Action}

Only twice does D'Alessandro portray hands involved in communicative interactions, capturing arguably significant gestures. First, p. 11 features the subject half-covered by the face of another inmate, in the foreground and out of focus. The subject looks to the left, with a very present look. $\mathrm{He}$ is probably taking active part in a conversation with someone outside the frame. The hands are joined at chest height, fingers spread, seemingly a variant of the Italian gesture for skepticism, doubt. Secondly, p. 32 shows a gesture that is possibly part of a communicative exchange (thumb and index finger touching, forming an $\mathrm{O}$ as in the OK gesture); this is, however, followed by two details of hands rubbing. The same subject writing on the wall (possibly using a small sharp object to scratch the paint/plaster) is featured on p. 13 and the pp. 14-15 double spread. The words are 
illegible, but it appears to be a rather long paragraph in very small handwriting. The person looks intently at the writing: in the first picture his hand is writing; in the second he seems to be polishing the writing with the little finger. The photographer is very close to the subject; the shot is intimate. Yet, despite looking over the inmate's shoulder, we don't have a feeling of voyeurism, possibly suggested by the use of the wide angle, which implies a closeness to the subject rather than the distance of a telephoto. The frame includes the back of the subject's head and part of his profile-we are not spying on his actions, we are participating in the writing and in his focused look. In three other instances, the images of hands involve food. At p. 53 a male hand handles an apple core, at p. 71 a female hand holds a sliced loaf of bread, and at p. 67 an elderly female hand seems to offer a piece of bread to someone, perhaps the photographer, though the image is too close for this to be clear.

\subsubsection{Intimacy, Abandonment, and Despair}

The postures and gestures featured in the images show abandonment and at times despair. On pp. 6 and 7, for instance, two inmates are portrayed sitting. The first picture is taken from behind, slightly above the inmate's left shoulder, and reveals that he might be tied to the gutter drainage pipe on which he is leaning. The second shot is a full-body right profile; the inmate's look points downwards, lost. He is also sitting on a low step; his hands are, significantly, concealed in his crotch. On p. 22, a strong plongeé frames an inmate crouched on the floor, sleeping with his hands and head between his knees. On pp. 42, 44, and 45 inmates in straitjackets are portrayed. The first is a full frontal, looking intently at the camera, possibly wriggling in the constraints. On p. 44 the inmate is sleeping, crouched on a bench. On p. 45 the inmate in the foreground is sleeping with his head down, while in the background another inmate in a straitjacket, slightly out of focus, seems to be looking at the back of the head of the first inmate, as if he were watching over him. On p. 47 there is the detail of a pair of hands joined in prayer, followed by a close-up plongeé portrait of an inmate whose head is covered by his jacket, hands joined in a gesture of prayer, a monk-like figure seemingly pleading, the "monaco scontroso della alienità" Piro (1967, p. 67) mentions in Popular Photography Italiana. The monk-like figure returns in the spread on pp. 50 and 51, where he is pictured from an even higher-angled point of view, eyes not visible under the jacket/hood, the head out of focus, the hands joined in 
prayer-the only detail in focus in the picture. Among the women's portraits, pp. 86-87 bear a large picture featuring three inmates crouching on the floor, the one in the foreground on the right with her eyes squeezed shut and head resting on the left hand, crying. In the middle ground, the woman has her right hand on her forehead, face entirely in the shade, expressionless. In the background, out of focus, a third inmate is sitting cross-legged seemingly looking at the others in the foreground. The picture is followed on p. 87 by the portrait of a woman wearing an expression of dismay, looking past the camera, hands brought to her face.

\subsubsection{Visual Alienation}

We can certainly identify several main tropes in Gli esclusi (hands, gestures, idleness, limited interaction, abandonment, despair, etc.). However, in stark contrast with the variety of images presented in the almost legendary photobook Morire di classe, the corpus of pictures presented in Gli esclusi is remarkably coherent and univocal. The photos are exclusively of patients; there is little to no interest for the facilities, the objects, or the medical staff. The leitmotif of the photobook is their alienation.

All patients are presented as alienated from the world (they are, after all, the excluded) and from their own selves. This is not so much (or at least not only) because of the mental disorder itself, as D'Alessandro initially thought (see also Forgacs 2014, p. 239), but also and especially because of the institution and society itself. The intimate focus on the hands and their humble, trivial, gestures presents us with individualized and atomized activities, devoid of human connection. It shows us individuals closed in on themselves, deprived of a voice, who seem to entrust their hands with the task of communicating in silence. Inmates are shown as idle, abandoned, in a state of despair and dismay or unconsciousness: they are alienated from society, made aliens to it. The only actions portrayed are very limited interactions and eating. Their physical presence is visually shrunk: inmates hide under their jacket ("Il vestito copre tutta la testa ed esclude l'uomo dal mondo degli altri, come una bara;" Piro 1967, p. 88), hunch their shoulders, and crouch. The most extreme example of this comes at p. 97 where a woman is portrayed crouched, with her legs huddled under her vest. Quite often, the photographer uses different degrees of high-angle shots (twenty-four pictures can be counted as plongée to different degrees, being more than a third of all images that are not details of hands). In contrast, there is only one picture in Morive di classe that can count as slightly plongeé. 
All these elements are a visual translation of alienation understood as a shrinking, the rimpicciolimento that the mental disorder initially causes but that is amplified by institutionalization.

\subsection{Conclusion}

With his work in the Materdomini asylum, D'Alessandro captured the multilayered notion of alienation as it was received in the struggle against institutional psychiatry. His photography contributed to the strategy of communication that would lead, in 1978, to the passing of the reform of mental health care and the beginning of the closure of asylums. Far from having a scopophiliac gaze, D'Alessandro's camera captured the alienation of inpatients, showing it both in terms of mental disorder and of social abandonment and marginalization. At the same time, he also captured an existential condition, the state of alienation in which we all live as human beings and which the processes of institutionalization leverage. Seen today, forty years after the ratifying of Law 180, his photographs show not only the inhumanity of the mental asylum of old, but also that the destruction of the mental asylum was certainly necessary and, quite simply, "obvious" (Basaglia 1964, p. 263).

\section{Notes}

1. The hard copy of the book has never been reprinted. A free online scanned version of the book was available until D'Alessandro's death in 2016. A cached version of the scanned book is available through Archive.org's "Wayback Machine." Piro's presentation is available at https://web.archive. org/web/20090207170253/http://www.lucianodalessandro.com/ esclusi/prespiro.html, accessed on August 3, 2018, while the scanned photobook is available at https://web.archive.org/web/20090205174019fw_/ http://lucianodalessandro.com:80/esclusi/esclus01.html, accessed on August 3,2018. The original printed photobook does not have page numbers. For ease of citation I have employed a custom page numbering whereby the first page with a photo is numbered 1 . The pages follow sequentially.

2. In 1968 Basaglia invited the photographer Carla Cerati to take pictures in Gorizia and other asylums. Cerati in turn asked Gianni Berengo Gardin to accompany her. A selection of their pictures was initially published by Einaudi in 1969, some months after Gli esclusi, in the photobook Morire di classe: La condizione manicomiale fotografata, edited by Basaglia and his wife, Franco Ongaro (Basaglia and Ongaro 1969). 


\section{REFERENCES}

Babini, Valeria. 2009. Liberi tutti. Manicomi e psichiatri in Italia: Una storia del novecento. Bologna: Il Mulino.

Basaglia, Franco. (1953) 2017. Il mondo dell'incomprensibile schizofrenico attraverso la Daseinanalyse: Presentazione di un caso clinico. In Basaglia, Franco. Scritti 1953-1980, 47-70. Milan: ilSaggiatore.

_ (1964) 2017. La distruzione dell'ospedale psichiatrico come luogo di istituzionalizzazione. In Basaglia, Franco. Scritti 1953-1980, 261-270. Milan: ilSaggiatore.

- (1965a) 2017. Corpo, sguardo e silenzio: L'enigma della soggettività in psichiatria. In Basaglia, Franco. Scritti 1953-1980, 301-14. Milan: ilSaggiatore.

_ (1965b) 2017. La "Comunità Terapeutica" come base in un servizio psichiatrico: Realtà e prospettive. In Basaglia, Franco. Scritti 1953-1980, 271-290. Milan: ilSaggiatore.

_. (1965c) 2017. Potere ed istituzionalizzazione: L'esclusione come categoria socio-psichiatrica. In Basaglia, Franco. Scritti 1953-1980, 291-300. Milan: ilSaggiatore.

- (1966) 2017. L'ideologia del corpo come espressività nevrotica: Le nevrosi neurasteniche. In Basaglia, Franco. Scritti 1953-1980, 345-332. Milan: ilSaggiatore.

-. (1975) 2017. Introduzione ad Asylums. In Basaglia, Franco. Scritti 1953-1980, 533-544. Milan: ilSaggiatore.

Basaglia, Franco, and Franca Ongaro Basaglia, eds. (1969) 2008. Morive di classe: La condizione manicomiale fotografata da Carla Cerati e Gianni Berengo Gardin. Trieste: Editore Duemilauno Agenzia Sociale.

Carli, Maddalena. 2014. Testimonianze oculari: L'immagine fotografica e l'abolizione dell'istituzione manicomiale in Italia. Memoria e ricerca 47:99-113.

Cesareo, Giovanni. 1981. Follia ed informazione nella stampa italiana. In Inventario di una psichiatria, ed. Carlo Pirovano, 29. Milan: Electa.

D’Alessandro, Luciano. 1967. Il mondo degli esclusi. Popular Photography Italiana 117: 51-54.

D'Alessandro, Luciano, and Sergio Piro. 1969. Gli esclusi: Fotoreportage da un'istituzione totale. Milan: Il Diaframma.

D'Autilia, Gabriele. 2012. Storia della fotografia in Italia: Dal 1839 a oggi. Turin: Einaudi.

Foot, John. 2015. Photography and Radical Psychiatry in Italy in the 1960s: The Case of the Photobook Morire di classe (1969). History of Psychiatry 26 (1): 19-35.

Forgacs, David. 2014. Italy's Margins: Social Exclusion and Nation Formation since 1861. Cambridge: Cambridge University Press. 
Foucault, Michel. 2008. Psychiatric Power: Lectures at the Collège de France, 1973-1974. Trans. Graham Burchell. New York: Picador.

Goffman, Erving. 1961. Asylums: Essays on the Social Situation of Mental Patients and Other Inmates. New York: Anchor Books.

Grassi. 1969. L’obiettivo penetra nel mondo degli “esclusi:” Eccezionale inchiesta nella "fossa dei serpenti". Roma, March 11.

Manzoli, Federica. 2004. La follia per immagini: Storia fotografica della fine dei manicomi. JCOM 3 (2): 1-7.

Piro, Sergio. 1967. Fotografia e alienità. Popular Photography Italiana 117: 55-88.

Russo, Antonella. 2011. Storia culturale della fotografica italiana: Dal neorealismo al postmoderno. Turin: Einaudi.

Sartre, Jean-Paul. 1978. Being and Nothingness: A Phenomenological Essay on Ontology. Trans. Hazel E. Barnes. New York: Pocket Books.

Schinaia, Cosimo. 2004. Fotografia e psichiatria. In Storia d'Italia. Annali 20: L'immagine fotografica 1945-2000, ed. Uliano Lucas, 459-476. Turin: Einaudi.

Sekula, Allen. 1982. On the Invention of Photographic Meaning. In Thinking Photography, ed. Victor Burgin, 84-109. Basingstoke/London: Macmillan.

Stefanile, Mario. 1969. Un reportage fotografico di Luciano D'Alessandro. Il Mattino, March 6.

Sforza Tarabochia, Alvise. 2014. Lacking Subjects and the Subject of Lack: Basaglia and Lacan. In Lacan and Philosophy: The New Generation, ed. Lorenzo Chiesa, 221-238. Melbourne: re.Press. 


\title{
"L'alienato nella cella è libero." Mario Tobino Between Le libere donne di Magliano and Per le antiche scale
}

\author{
Wissia Fiorucci
}

\subsection{INTRODUCTION}

A psychiatrist as well as a prolific author, Mario Tobino (1910-1991) gained literary recognition with Le libere donne di Magliano in 1953. This is a collection of narrative fragments, in diary form, which fictionalize his experiences as a psychiatrist in the asylum of Maggiano (Lucca), during the years 1950-1952. ${ }^{1}$ The theme of madness recurs throughout Tobino's oeuvre, being central to the aforementioned text as well as to Per le antiche scale (1972), Gli ultimi giorni di Magliano (1982), and Il manicomio di Pechino (1990). In these works, Tobino puts the asylum "al vertice di una gerarchia di valori, una sorta di emblema da difendere ad oltranza," even depicting it "come una realtà che si può amare" (Andreoli 2008, p. 172). By looking at Le libere donne di Magliano and Per le antiche scale, in this chapter I will offer a critical insight into Tobino's conception of the asylum as a response to mental illness: framing his thought in between those

\footnotetext{
W. Fiorucci $(\bowtie)$

University of Kent, Canterbury, UK

e-mail: W.fiorucci@kent.ac.uk
}

(C) The Author(s) 2019

A. Diazzi, A. S. Tarabochia (eds.), The Years of Alienation in Italy, https://doi.org/10.1007/978-3-030-15150-8_12 
two works is fundamental to understanding his position regarding Law 180 of May 13, 1978, ${ }^{2}$ and thus the debate surrounding it during the socalled years of alienation. To this end, looking at the 1953 text will allow me to demonstrate that, despite the many changes in psychiatry during the period studied in the present volume, Tobino's position never changed.

Firmly averse to the "nuova psichiatria," in Antiche, Tobino (1972, pp. 11-12) wrote: "I medici giovani, psichiatri innovatori" believe that mental illness "non esiste." 3 Attacking Law 180 and its implementation, he also engaged in a harsh dialogue with Basaglia himself (see De Vecchis 2010).

In the first section of this chapter, I will examine Basaglia and Tobino's dispute, focusing on three main points that informed it: the nature of mental disorders; institutionalization in the asylum as an answer to them; and the role of the psychiatrist within the asylum, and thus his relationship with patients. Drawing on these issues I will then proceed, in the second section, to examine Tobino's representation of alienation in Libere. I will demonstrate that, in conceiving of his work as "un appello morale alla coscienza dei sani" (Bresciani Califano 2011, p. 26) in an effort to raise awareness of inmates' conditions in asylums, Tobino lets emerge, in his texts, his conviction that madness is intrinsically incompatible with society. That is, he showed in his writings that, for reasons of social decorum and containing danger, confinement was to him the best option-and it was so for society rather than for the madwoman. This is evident in what he chooses to reveal in his descriptions of madness and in how he goes about this. Focusing on the author's portrayals of his female patients, and comparing these fictional renderings with a number of clinical folders on the real-life cases from Maggiano, I will show how Tobino, rather than instigating pity and compassion in readers, patently wanted to make them avert their gaze. His grotesque and detailed depictions of female patients, especially when they engage in sexual acts, reveal both his intention to show to the "sane" why the "insane" should be locked up, and his belief that female madness goes hand in hand with unrestrained sexuality (and thus dangerousness). At the same time, I will also demonstrate how his attitude towards madwomen took the standpoint of the privileged perspective of his (male) gaze, in a blatantly chauvinistic attitude. 


\subsection{Tobino and Basaglia: What Is Madness?}

On April 18, 1978, in La Nazione, ${ }^{4}$ Tobino claimed that "quello che nettamente mi divide da [Basaglia] è che io [...] ho partecipato, ho sofferto della follia, $[\ldots]$ lui $[\ldots]$ dice che non esiste, sono i padroni che hanno tirato su i manicomi per tirarvi dentro i diversi, i disturbatori del loro dominio." 5 He had previously conveyed this point through the words of his alter ego Dr. Anselmo in Antiche: "Per i giovani la follia è solo un misfatto della società, $[\ldots]$ non una solenne misteriosa tragedia" (Tobino 1972 , p. 125). It is anything but easy to trace a consistent "linea di pensiero" in Tobino's works, in that "non sempre si mostra coerente nelle sue affermazioni." Much like Szasz (1960), Tobino (2012, p. 114) goes so far as to ask himself: "La pazzia è davvero una malattia?" He will never answer this question, and in both books herein analyzed he refers to it in various ways that often have little or nothing to do with psychiatry. More specifically, Tobino's romanticized conception of madness stands at an implausible intersection between beastliness and divinity. For him, madness could be "una delle misteriose e divine manifestazioni dell'uomo [...] una sublime felicità che noi chiamiamo patologica e superbamente rifiutiamo" (Tobino 2012, p. 114; my emphasis). In Antiche, however, he writes: "Gridò il suo orrore [per] essere stata tanti anni vicina a questi malati senza percepire la maledizione che portavano nel sangue" (Tobino 1972, p. 113; my emphasis). At the end of the book Anselmo even refers to his work as "l'altezzosa ricerca di una logica," which would ultimately amount to "costringere la sua fantasia," that is the inmate's imagination, "alla nostra misura” (p. 247; my emphasis).

Overall, despite the many oscillations, we can grasp an "idea fondamentale" that brings Tobino close to Lombroso through "il concetto di una fatalità della follia" (Andreoli 2008, pp. 169-170). This is apparent, for instance, when Tobino (2012, pp. 30 and 57) refers to madness as something intrinsic, innate, to a person's "nature:" “È costretta dalla sua natura a comportarsi così;" or "non trovava nell'ambiente alcun alimento per la sua natura." In stark contrast with these somewhat insubstantial positions, Basaglia never stopped seeing madness as a pathological condition that makes human beings suffer: famously in Conferenze Brasiliane (1979) he said that madness exists as an illness in much the same way as flu does. That is to say, for him there was nothing innate, mysterious or godlike about the condition of madness: "La follia esiste ed è presente come lo è la ragione. [...] Il problema è [...] superare la follia istituzionale 
e riconoscere la follia là dove essa ha origine: nella vita" (Basaglia 2000, p. 34). Madness is a condition that the physician must treat, and must do so outside the asylum, because the latter is a total institution, to use Goffman's term (2007); that is, a "prigione in cui l'inferiorità morale del recluso era scientificamente sancita, e la reclusione scientificamente giustificata" (Basaglia 1967, p. 449). Conversely, Tobino (2012, p. 40) went so far as to say that "l'alienato nella cella è libero." Thus, when he wrote this sentence in 1953, he was not only defending the asylum itself, but also the practice of confining the agitate in a cell-a practice he never questions and actually even justifies by pointing to the danger posed by inmates and their beastliness: "Il manicomio si divide in maschile e femminile. Ciascuna divisione è ordinata e disposta secondo il grado di agitazione e pericolosità. Si parte dai tranquilli e si arriva agli agitati, tutti hanno deliri, alcuni come bestie ruminano e respirano" (Tobino 2012, p. 22; my emphasis). In his 1963 preface to Libere, he explained what had prompted him to write it: "Il mio scopo fu ottenere che i malati fossero trattati meglio, meglio nutriti, meglio vestiti, si avesse maggiore sollecitudine per la loro vita spirituale, per la loro libertà" (p. 112)—thus restating his faith in the institution whose circumstances, however, he wanted to improve for the sake of the mentally ill. His position, if read through Basaglia's critical viewpoint, may seem as ineffective as those positions held by anti-psychiatrists (a term that needs to be used with caution, as discussed in Foot 2015), an apparent comparability due in part to his wavering conception of madness. Ultimately, for anti-psychiatrists, it is society that is ill, and what we define as mental illness is the individual's process of healing from it; in fact, madness may even be seen as a liberation from societal constraints. ${ }^{6}$ According to Tobino, this liberation can only happen in institutionalized confinement. The title of Tobino's 1953 text is rather self-explanatory: for him, the asylum allows the insane to express their insanity in a protected environment. When Tobino $(2012$, p. 40$)$ describes the agitate, their confinement is explained as a condition for which, paradoxically, "l'alienato [...] sbandiera, non tralasciandone alcun grano, la sua pazzia, la cella [è] il suo regno dove dichiara se stesso, che è il compito della persona umana." This position is totally incompatible with Basaglia's perspective. For the latter, the walls of the asylum had to be taken down, regardless of what was going on inside: whatever the degree of humanization achieved in terms of individual experiences, Basaglia warned that society would always have a convenient place to segregate its deviants so long as mental institutions existed (see Basaglia 1964). In this connection, the role of the psychiatrist 
as the guard of the inmates, invested with this task by the political powers that governed the asylum, was crucial to Basaglia's understanding of this institution and of the power dynamics at work within it.

In the context of institutional psychiatry (i.e. in the asylum) there seems to be a strict hierarchy at work: the director (a psychiatrist) is the unquestioned master of the institution, followed by other psychiatrists, nurses, support workers, and finally the inmates who are, allegedly, at the bottom of this pyramid of command. Yet for Basaglia institutional psychiatry does not actually work as a medical discipline that aims at treating mental disorders, but as an instrument of social control that forces the psychiatrist into the role of master and the inmates into the role of slaves (to use the classic Hegelian dialectics). ${ }^{7}$ This is one of Basaglia's (1975, p. 710) main tenets: psychiatrists are "funzionari del consenso." They work for society by contributing to the maintenance of the social order, rather than acting primarily as medical professionals specializing in the treatment of mental disorders. This was already a central consideration in one of his "manifesto" publications, his 1968 L'istituzione negata: "Nel momento in cui neghiamo il nostro mandato sociale, noi neghiamo il malato come malato irrecuperabile e quindi il nostro ruolo di $[. .$.$] tutori della tranquillità della$ società" (Basaglia 2012, p. 70; my emphasis). The awareness of being a "guarantor of social order" is absent in Tobino, and he never seems aware of that mechanism of power of which he is a pawn, just as he never questions "quel ruolo di presa sul paziente da parte dello psichiatra," denounced by Basaglia, which in turn traps patients in their passivity (Colucci 2011, p. 26). This passivity, for Basaglia, is primarily responsible for negating the "spazi di espressione riguardo alla sua esperienza di follia" (Colucci 2011, p. 26), an idea that is in patent contrast with Tobino's view that the madwoman is free in her cell.

Tobino's lack of awareness with regard to institutional power led to a number of consequences that are evident in both works herein analyzed. First, there is no critical questioning, on Tobino's part, of the laws that governed the asylum. In Antiche, for instance, he mentions Article 4 of the Legge Mariotti of March 18, 1968, ${ }^{8}$ which introduced voluntary admission to the asylum. This allowed for a possible loophole: patients could convert their stay into voluntary. In the section "Anselmo ha paura e si sbaglia," the latter struggles in applying this article, which is "di difficile e rischioso maneggio" (Tobino 1972, p. 120). Yet the doctor sets out to do as told, as if his task as a medical professional were merely that of obeying institutional power without ever questioning it. Though Anselmo seems 
to approve of the new regime of relative freedom that has brought "felicità," it is obvious that the law itself is still "nuova, da discutere" (pp. 119-120) and that he does not really know how to handle it and its consequences. But he accepts it without ever criticizing the passivity implied in his role that, as is evident in this episode, ultimately amounts to mediating between the framework laid out in the law and its practical implementation. Even at the beginning of the book, when Dr. Bonaccorsi and his colleagues decide to retire following Mussolini's ascent to power, on the author's part we find a very feeble response to the way "il fascismo, che prima aveva circondato il manicomio, poi era soffiato dentro." The narrator merely comments that "di questo nuovo mondo loro erano alieni, diversi. Alzare il braccio nel saluto sembrava loro ridicolo [...] Decisero di andare $[\ldots]$ in pensione" (p. 53)..$^{9}$ This reflects Tobino's own passive attitude. Although he claimed to be a first-hand witness of madness- "I have seen it," he said (1978) — "sul piano scientifico [...] il suo contributo come psichiatra è stato praticamente nullo [...], limitandosi a gestire l'esistente" (Piazzi in Maggiorelli 2010).

Another evident consequence of Tobino's lack of awareness is the way he conceived of the asylum's hierarchy as somehow both normal and incontrovertible. This is in turn strictly linked with his view that, as mentioned above, madness is "fatalmente immutabile" (Andreoli 2008, p. 179). Seen from Tobino's perspective, the mentally ill woman-doomed to her destiny of madness - is never a protagonist in his books. Relegated to the bottom of the pyramid of power, "non ha storia" and, as I will further explain in the next section, "rimane relegato al suo ruolo di puro e semplice lusus naturae" (Andreoli 2008, p. 186). Conversely, for Basaglia:

Non è che noi prescindiamo dalla malattia, ma $[\ldots]$ nel momento in cui io dico: $[\ldots]$ è uno schizofrenico $[\ldots]$ io mi rapporto con lui sapendo $[\ldots]$ che la schizofrenia è una malattia per la quale non c'è niente da fare. [...] Per questo è necessario avvicinarsi a lui mettendo fra parentesi la malattia perché la definizione della sindrome ha assunto ormai un giudizio di valore, di un etichettamento che va oltre il significato reale della malattia stessa. (Basaglia 2012, p. 70)

Thus, while for Basaglia it was central to establish a relationship with patients that transcended their illness, Tobino would not look past their diagnoses: this is especially the case in Libere, where he treats his patients as being one with the illness from which they suffer. ${ }^{10}$ In Antiche, on the 
other hand, we have one instance in which "il dottor Anselmo fu soltanto amico di quei malati, si scordò $[\ldots]$ di essere psichiatra" (Tobino 1972, p. 186). This is possible within the context of the café inside the asylum, which is basically run by patients (in real life, this was part of the "humanization" of the asylum that Tobino wanted to carry out in Lucca), ${ }^{11}$ but also by the fact that the patients in question were all men, and with them Anselmo/Tobino shared the experience of World War II. This is a rather isolated episode, dictated mostly by Anselmo's need to forget, even if only momentarily, his being a psychiatrist (though it is interesting to notice that before going to the bar "si infilava il camice" (Tobino 1972, p. 187), and it will be remembered how Basaglia "discontinued the use of the white coat" to reduce "the distance between doctor and patient" (Sforza Tarabochia 2013, pp. 98-99). In order for Anselmo to take a break from his role, it is necessary that his (male) patients are freed of their diagnoses too, and "mai aveva ricercato le loro cartelle cliniche" (Tobino 1972, p. 189), otherwise there would be no possibility for him to be a "friend of those sick people." Yet even on this occasion Tobino does not call patients simply "people," without qualifying this by stressing that they were sick. Later on in the same text, he writes: "Desideravo, preferivo intrattenermi con lui come un buon conoscente, quasi come un amico, non volevo assolutamente ricordargli che era marcato col timbro della maledetta dea" (Tobino 1972, p. 213; my emphasis). He is unable to see mentally ill patients as human beings suffering from a medical condition that, as a physician, he should try to cure just like any other illness. For Tobino, madness indeed exists but he never figures out whether or not it is to be considered a proper illness (though he does refer to inpatients as "malati," see, for example, Tobino 1972, p. 186). This in turn leads him to look at his patients not as fully fledged humans but as creatures whose condition he sees as something ineffable, and perhaps even divine ("a damned goddess"), which as such should not be tamed. He writes in 1963 that the "psicofarmaci $[\ldots]$ hanno talmente cambiato i manicomi che $[. .$.$] non si$ riconoscono più, le urla sono taciute, i delirî rotti, le allucinazioni con i vetri affumicati" (Tobino 2012, p. 112; my emphasis). These new tools are seen by Tobino $(1972$, p. 41 ) as a constriction, as they make mental illness "ovattata, dissimulata, intontita, mascherata, camuffata." Overall, he rejects any attempt that is aimed at handling outbursts of madness: "Quando un malato si illumina di fantasia, lo rinchiudi. Facile [...] hai avuto paura della follia e invece di [...] comprenderla le hai messo le manette" (Tobino 1972, p. 127; my emphasis). Thus, for him, trying to 
tame madness, whatever the method, is the easy way out-and yet he is an advocate of the asylum, a contradiction that should itself undermine his viewpoints. Yet critics of Tobino-both now and around the time of publication of Libere - tend to comment positively on his views, ${ }^{12}$ often taking his side in the dispute with Basaglia. For instance, Marabini (1969, p. 243) comments that in Libere "l'amore Cristiano e la pietà si esaltano per un inno alla vita," while De Vecchis $(2012$, p. 182) goes as far as to say that "il tempo $[\ldots]$ comincia a dare ragione alle intuizioni di uno psichiatra, ch'era principalmente [...] uomo," in a comment that is as groundless as it is meaningless. I find these affirmations not merely questionable but actually misleading. Though in 1953 the reform was still far away in time, Tobino's authoritarian relationship with his patients (for instance, he uses the word "interrogatorio" when he asks them questions; see e.g. Tobino 2012 , pp. 57-78) was in no way moderated by his alleged "compassion" or "Christian love." 13 Moreover, in the 1972 text Tobino (1972, p. 115) describes a restraining practice that he actually justifies by explaining it: "Quando un malato [...] compie qualcosa di insolito [...] viene trasferito $[\ldots]$ in Vigilanza, dove sarà osservato, studiato;' this is the 'reparto chiuso, dal quale non si può uscire."

Certainly, the use of repressive methods such as isolation cells, interrogations, and force-feeding, is partly mitigated in Libere by "qualche atteggiamento che ricorda il trattamento morale alla Pinel," which seems however to be mostly dictated by personal feelings towards individuals, rather than by strong and far-reaching ideological convictions (Andreoli 2008 , p. 163). Tobino never stops seeing himself as the master of the asylum, and thus his patients as patients. Rather tellingly, his descriptions of inmates in Libere were drawn from, and inspired by, their medical folders. ${ }^{14}$

\subsection{The Captive Human Beasts of Magliano}

Tobino did not follow a consistent criterion in choosing which and how much data from medical folders to transpose into his literary text, or in interpolating invented data. But what emerges from a comparison between folders and fiction is that, for him, inmates are completely alienated in the role assigned to them by institutional psychiatry. For instance, in Berlucchi's case, Tobino omits the episode believed to be the root of her mental ailments (which is, however, included in the medical folder), as he focuses instead on her attempted suicide. We read in the folder that "Da giovane fu ammalata di polmoni. [...] Furono contagiati da essa un fratello, una 
cognata ed una sorella, i quali morirono di tubercolosi. Ora prova un forte rimorso $[\ldots]$ che non le dà pace." In the fictionalized text no mention is made of this, and Tobino $(2012$, p. 28$)$ gives instead graphic details of the suicidal gesture: "Un ferro da calza dalla parte del cuore, se lo è conficcato tutto sì che una punta affiorava appena nella pelle della mammella sinistra, l'altra punta emergeva nel dorso." He leaves the reader in the dark as to the guilt that had caused Berlucchi first to lose her mental health and then to attempt suicide in a rather significant way: devoured by guilt for having infected her family with a lung disease, she tries to kill herself by inserting a needle through her chest. With topo pallido Tobino follows a similar procedure; that is, he extracts one element from the folder, and expands it until the character is built exclusively around it, and in it she is alienated. Topo pallido, we read in the folder, is afraid of having passed on pleurisy to her children, but this worry is reduced to a meaningless obsession in the fictional text. It is meaningless, because we do not know where it came from: "Questa donna non è che abbia uno scopo [...]: ha solo quel pensiero della pleurite e non avendo altri pensieri, [...] ripete quell'unico pensiero" (Tobino 2012, p. 26). In the case of Professoressa Galli (or of le cucitrici), Tobino opts for inserting fictional elements, rather than omitting real ones: "Crede $[\ldots]$ che io sia suo marito e da questo connubio siano nati due figli, $[\ldots]$ odia Suor Giacinta $[\ldots]$ perché è sicura che sia la mia amante $[. .$.$] In queste lussurie io sono il crudele e amato protagonista"$ (p. 42). In the folder, the various references to her sexuality do not include Tobino and can be summarized, in terms of its content, in the last note he wrote: "Vivissime allucinazioni $[. .$.$] a contenuto sessuale e persecutorio$ [...]. È dichiaratamente lesbica." Hence, Tobino includes invented elements to picture himself as the woman's object of sexual desire, which leads us to a crucial aspect of his descriptions of inpatients in Libere.

It is rather surprising that, in making claims about Tobino's alleged pietas and mercy, the majority of critics completely and systematically disregard the insistent eroticization in his descriptions of female patients, which indicates an attitude that we may define as voyeuristic: "Bella e furente nella chioma nera e nell'espressione del volto, il petto sodo e gonfio, il ventre liscio, le cosce robuste, affusolate le gambe" (Tobino 2012, p. 46). In Andreoli's words, "sembra quasi che le matte facciano spettacolo per un osservatore privilegiato qual è lo psichiatra" $\left(2008\right.$, p. 181). ${ }^{15}$ The examples are many, and Tobino's focus on the inmates' attractiveness does not end with descriptions of their bodies. Not coincidentally, summer is the dominant season in Libere. ${ }^{16}$ This is the period of the year when, 
according to the author, the erotic character of female madness manifests itself more freely: "La bava, la lussuria estiva, le donne che si toccano, si abbracciano, la saliva, gli occhi languidi lucidi: [...] nei reparti femminili, senza pudicizia si scarica la sensualità. È d'estate" (Tobino 2012, p. 185). Tobino's descriptions of his patients' sexual behaviors betray a morbid attention on his part, at times even leading him to some questionable conclusions: "Viene il sospetto che le matte sian guidate dall'odorato più che dalla vista, e ciò che più sa di bestia sia perseguito, oppure le sessuali per soddisfarsi ... si avvicinano a quelle più facili [...] perché senza senno $e$ morale, il soddisfacimento essendo soltanto lo scopo: far gemere quelle mucose sensibili" (p. 107; my emphasis). This problematic nexus between female madness and sexuality is reiterated in Antiche: "Nel silenzio della notte arrivavano i lamenti $[\ldots]$ dalla parte degli uomini, e $[\ldots]$ nella divisione femminile $[\ldots]$ in più gemeva la miseria del sesso" (Tobino 1972, p. 41).

As mentioned above, Tobino claims in the preface to the 1963 edition of the Libere that his goal in writing has been to unveil the conditions of the insane in the asylum, in order to urge their improvement. Yet what he does instead is offer his readers grotesque representations of patients as seen through his privileged gaze:

Alle 'agitate-donne' $[\ldots]$ ha spesso furore il tribadismo-lesbismo $[\ldots]$. È solo stupefacente che una bruttezza ne ami un'altra con tale spudorato abbandono, sembra che siano solo le mucose che si cercano gemendo; donne anziane sdentate, gli occhi cisposi e strabici, [...] ragazze dementi, imbecilli che scolano saliva dalle labbra pendenti; bruttissime, goffe, zoppe.

(Tobino 2012, p. 105)

Furthermore, "le donne" are depicted not only as "oscene," but also as "cattive," as Basaglia (quoted in Castelli 1978) commented. Tobino frequently insists on their violence and dangerousness, which justifies their imprisonment in his eyes: "Arrivò in manicomio con tale agitazione che si dovette subito rinchiuderla in cella, dove nuda fece dell'alga dei raggi sensuali e semidivini" (Tobino 2012, p. 46). In his Lombrosian description of la Benni, Tobino (p. 57) associates female madness not only with sexuality and danger, but also with criminality: "È una criminale $[\ldots]$ viveva con la prostituzione che esercitava come una diavolessa e i suoi coraggiosi frequentatori forse non valutavano il pericolo che correvano." 
When the book was written, psychiatrists did not have effective therapeutic tools at their disposal. The first antipsychotic drug, chlorpromazine, was in fact only introduced in 1952. The point is thus not to question Tobino's choices as a psychiatrist, which at the time of writing Libere would have been limited, but to highlight that he did not unveil the inhumane conditions of life in the asylum. Rather, it appears evident that Tobino was advocating the view that the madwoman had to be separated and removed from the eyes of sane society for reasons of containing danger while upholding social decorum. In the 1972 text, descriptions of patients are not as laden with grotesque details, owing to the fact that the introduction of antipsychotic drugs had radically changed their behaviors - and Tobino also focuses at length on other inhabitants of the asylum (especially Dr. Bonaccorsi and Dr. Anselmo). Yet references to the dangers inherent in madness are also found here: "Oggi è di moda [...] sdrammatizzare la pazzia, dichiararla non pericolosa" (Tobino 1972, p. 111; my emphasis). We also find a clear equation of female madness with sexuality and dangerousness: "A dodici anni portò alla malora un ferroviere, lo costrinse alle sue voglie; fu poi lui condannato per costrizione di minorenne" (p. 213). Tobino here speaks of a twelve year old, stating that this child was so dangerous because of her mad sexual appetite that she made an older man go to prison for her:

La 'bionda' $[\ldots]$ mi guarda con gli occhi brillanti-lieti di sicura futura voluttà $[\ldots]$. Ogni mattina mi aspetta; mi affaccio allo spioncino della cella, subito i suoi occhi brillanti mi fasciano; $[\ldots]$ mi sembra di essere $[\ldots]$ un novello sposo che dopo una notte d'amore, allontanatosi per pochi minuti, torna presso di lei e la ritrova ancora tutta calda di lui. (Tobino 2016, pp. 78-79)

There is a clear moral judgment in the way this situation is described, besides the obviously problematic implications of the statement itself, which accuses a minor of sexual predation. Overall, Tobino's descriptions are clearly aimed at explaining why madness must be dealt with far from the eyes of the sane, in light of its intrinsic dangerousness and obscenely sexual character: "Come bestie nelle tane le malate infreddolite dentro le celle," where "l'erotismo si fa più selvaggio e gradatamente aumenta l'acuto rancido della bestia umana" (Tobino 2012, pp. 24 and 28). 


\subsection{Conclusions: The Psychiatrist's Gaze}

Tobino's moralistic attitude towards his patients' sexual mores is evident from the very beginning of Libere, in its first fragment: "Aveva la camicia aperta sì che si vedeva comodamente un seno. Non aveva alcun pudore, neppure la finzione del pudore" (Tobino 2012, p. 22). Furthermore, as mentioned above with reference to Elsa Galli, in Libere he goes so far as to depict himself as the object of his patients' fantasies: "Alle 'agitate' dai letti, in camicia, nude, si lanciavano verso di me, che fuggivo" (p. 28). The idea of being an unwilling victim of the women's unbridled sexuality is explicit in this quote, where Tobino draws an image of predatory female sexuality to which, in this case, the male responds by running away. In the case of la bionda, conversely, Tobino's male gaze openly addresses its object through the peephole that allowed the psychiatrist to look undisturbed at his incarcerated patients.

Freud (1962, p. 23) defined scopophilia as the pleasure in looking. Scopophilia thus implies attaining sexual stimulation through sight by subjecting people "to a controlling and curious gaze": an example of this is a "peeping Tom" (Mulvey 1999, p. 835), whose sexual satisfaction completely derives from this activity. Drawing on Mulvey, we can say that la bionda - visible through the peephole-plays a "traditional exhibitionistic role;" that is, her body is reduced to a passive sexual object by and for Tobino's gaze, so that his fantasies can be projected unto her. She thus signifies "to-be-looked-at-ness" (Mulvey 1999, p. 837). Tobino describes la bionda (and also la Campani; Tobino 2012, p. 41) as a willing participant in this game where she plays the passive object, yet in reality her "tobe-looked-at-ness" cannot be a choice, because she has not chosen her condition of reclusion. Conversely, Tobino is an agent of the look, enjoying displaced control and possession of the madwoman through the peephole. Additionally, in this interaction between agency and passivity where the latter is an inflicted condition and not a choice, the viewer's agency is also reinforced by the factual control he has over the woman's imprisonment. As her doctor, ${ }^{17}$ he could free her from the cell: he does not merely enjoy agency through looking, he has the power to end her imprisonment and thus her "to-be-looked-at-ness."

The voyeuristic element is an aspect of Tobino's work that critics (except for Andreoli) have surprisingly failed to address. In fact, Martinucci (1995, pp. 132-133) says that "è abbastanza lineare il passaggio che rende il medico/narratore, unico uomo fra tante donne, oggetto dell'amore di 
queste ultime." Furthermore, the women in question are “'matte,' o meglio, $[\ldots]$ 'libere,' svincolate quindi da tutte quelle regole $[\ldots]$ che potrebbero inibire l'aperta manifestazione delle passioni $[\ldots]$ erotico-amorose." That is, while uncritically accepting Tobino's description of his patients, she also endorses his view that the madwomen were, in fact, free to express their desire-hence upholding a problematic and century-old connection between unbridled female sexuality and madness (e.g. in the midnineteenth century, "Western psychiatric medicine" regarded women as "far more prone to insanity than men;" they were believed to be sexless by nature and thus "sexual excess" was "offered as explanation for the preponderance of women in asylums" Brown 1986, p. 372).

More generally, critics tend to fall prey to Tobino's nostalgic and romanticized renderings of the asylum and of madness, so much so that Bresciani Califano (2011, p. 62) even seems to be mimicking his decadent lyricism: "Il farmaco $[\ldots]$ mette dunque a tacere il magma ribollente che viene così tenuto a freno $[\ldots]$. La materia nera diventa un tessuto plumbeo, un grumo che non prende forma e la malinconia che dentro ribolle viene soffocata." She even declares that "l'interesse partecipe alle vicende femminili si carica a volte di toni tenerissimi anche se mai esplicitati e tutti sobriamente affidati a un linguaggio asciutto" (Bresciani Califano 2011, p. 68). Tobino's language cannot be defined as "dry" (it is, on the contrary, very elaborate and laden with metaphors and similes) and his gaze, I have shown, is certainly not sober and it is very explicit.

To conclude, I endorse Andreoli's claim that Tobino should be held responsible for the unprofessional and uncritical representation of the asylum and, consequently, also of mental illness that he has given in his books. Madness is not an immovable concept - as shown by Foucault, the notion of mental illness changes with history, and cultural products are vehicles through which madness has been portrayed for the general public across the centuries. Being one of the few who described life in an Italian asylum, Tobino "ha senza dubbio contribuito a trasferire nella cultura e nell'opinione pubblica una certa immagine del mondo manicomiale e [...] della psichiatria contemporanea" (Andreoli 2008, p. 173). Unfortunately, he did so by transmitting conventional and outdated ideas which have no place in modern psychiatry, celebrating a notion of asylum that he draws from old stereotypes, including the idea that madness "si adatta molto più facilmente al mondo della donna" (Andreoli 2008, p. 188) in light of her dangerous and obscene sexual instincts. In so doing, Tobino also continued to endorse the century-old view that the mad person, whose beastliness requires confine- 
ment, is at the same time a creature "beyond the human"-close to God perhaps, but not really a person: "In lei tutto ormai [era] confuso: bestia e dea" (Tobino 1972, p. 46). Moreover, Tobino's sexualized and sexualizing gaze instigates an objectifying voyeuristic process that is all the more objectionable because these women were both suffering from a mental disorder and institutionalized: thus, their "to-be-looked-at-ness" could by no means be considered voluntary. Tobino projects on them erotic fantasies, freely observing them with what can only be described as a morbid and voyeuristic curiosity. His voice should thus have no further weight in the debate that continues to surround Law $180:^{18}$ he was a psychiatrist with wavering ideas who took advantage of his position, "compiace[ndosi] della sofferenza" of those women he depicted as both obscene and dangerous, spying on them in "quei camerini dove $[\ldots]$ erano state recluse $[\ldots]$ perché non dessero fastidio a nessuno" (Basaglia quoted in Castelli 1978).

\section{Notes}

1. Before Tobino, only Corrado Tumiatti in his Tetti rossi (1931) had described the experiences of a psychiatrist working in an asylum.

2. Law 180 dealt with the "Accertamenti e trattamenti sanitari volontari e obbligatori," and opened with the line: "Gli accertamenti e i trattamenti sanitari sono volontari." Law 180 was soon incorporated into Law 833, which established the National Health Service (23 December 1978). Law 180 banned long-term residential facilities for psychiatric health care (such as asylums, psychiatric hospitals, and psychiatric wards in general hospitals), and regulated the Trattamento Sanitario Obbligatorio (involuntary hospitalization), repealing the main articles of Law 36 of February 14, 1904, "Disposizioni sui manicomi e sugli alienati: Custodia e cura degli alienati."

3. He was here referring to "those 'alternative' psychiatrists" that include Basaglia, thanks to whose political activism "the general population was made aware of the backwardness of Italian psychiatry [catching] the attention" of the psychiatrist Bruno Orsini (b.1929), the Christian Democrat Senator who formulated Law 180 and successfully campaigned for its approval (Sforza Tarabochia 2013, p. 2). For Tobino, “[s]mantellare le strutture ospedaliere e rispedire i malati a casa [...], in funzione di un modello astratto che prescinde da qualunque valutazione specifica del singolo individuo e dalla gravità del suo male", was "una scelta $[. .$.$] semplicistica"$ (Bresciani Califano 2011, p. 71).

4. According to Vecchis $(2010$, p. 183), the article, titled "Lasciateli in pace, è casa loro," would have influenced the formulation of Article 8 of Law 180. 
5. Basaglia (quoted in Castelli 1978) replied: "Il rapporto [...] fra informazione e disinformazione si squilibra a vantaggio della seconda quando si affidi alla penna cechoviana di uno scrittore l'analisi di un ambiente che è in realtà la tesi dell'ideologia dominante. Oggettivamente il suo scritto rende un grosso servizio al potere."

6. For a detailed account of "anti-psychiatry" see Sforza Tarabochia (2013, pp. 68-74).

7. In a comic vignette produced by the art collective Arcobaleno, created in 1972 and led by artist Ugo Guarino (1927-2016) in the asylum of Trieste, we read: "Noi degenti e lavoratori dell'ospedale psichiatrico di TS siamo tutti nella stessa pentola [...]!” This exclamation is uttered by four sketched people who pop out of a pot: these are the inmates of the asylum but also the workers (a cook and, it seems, a nurse). What this poster suggests is that all the elements of the pyramid are equally subordinated to the institution itself.

8. This was the Legge 18 marzo 1968, n. 431 Provvidenze per l'assistenza psichiatrica published in the Gazzetta Ufficiale no. 101 on April 20, 1968.

9. Tobino (1972, pp. 155 and 171) returns to Fascism later on, but never engages in a discussion on the ways the regime had instrumentalized the asylum.

10. As a matter of fact, he does not focus on the asylum itself nor on psychiatry as it was practiced therein: the confinement "all'alga" is the only practice that is described in some detail. Electroshock (Tobino 2012, pp. 87 and 99) as well as force-feeding (p. 33) are only referred to in passing (on Tobino's view of electroshock see De Vecchis 2010, pp. 176-177, n. 14).

11. See De Vecchis (2010, pp. 175-178).

12. For instance, Tobino's nephew Zappella (2010, p. 159) comments on the debates that preceded the formulation of Law 180. Throughout the essay, strong accusations and sarcasm (he calls the ideological movement that culminated with the closure of asylums "la Moda" with a capital "M;" Zappella 2010, p. 161) are reinforced by rhetorical reflections (e.g. he writes that the government that passed Law 180 was the same that "faceva morire Aldo Moro" Zappella 2010, p. 159). The problems in this essay are repeated in several works by supporters of Tobino's. They laud his alleged good intentions, which frequently results in an unsubstantiated and blind defense of his viewpoints on Law 180.

13. Tobino also referred to former prostitutes in patently judgmental tones: besides Benni in Libere, we read in Una vacanza romana: "Ben povera di senso morale, di buon senso, di giudizio" (1992, p. 155). This was the seventeenth of twenty-four clinical folders from Maggiano that Tobino included in an appendix to this text. Other clinical folders have been transcribed by Martinucci (1995) in her thesis: pp. 108-110 (Benni); pp. 112-113 (Canti); 
pp. 115-117 (Chiromante); pp. 121-124 (Berlucchi); pp. 127-29 (Galli Elsa); pp. 134-137 (Cucitrici). She also included a selection in appendix, pp. 145-154 (Lella, Signora Alfonsa, Sbisà, Marzi, Signora Maresca, Fratesi).

14. On Tobino's method in writing his patients' stories, see Del Beccaro (1967, p. 25).

15. Explicit descriptions are more conspicuous in Libere, but we find such references also in Antiche: "Una bellissima donna [...]. Si ricordava Anselmo [che] sotto le vesti, sotto la camicia, continuava la bellezza" (Tobino 1972, p. 122).

16. The passing of time in Libere is signaled by references to the seasons: the first section covers a period of time that goes from spring to summer, the second a subsequent period covering the months from the autumn to the summer of the following year, and the third goes from summer to autumn.

17. In the Professoressa's fragment we find another voyeuristic element: "In queste lussurie [...] né manca di apparire Suor Giacinta, a dirigere tutto ciò" (Tobino 2012, p. 42).

18. See for instance Battistini (2018).

\section{REFERENCES}

Andreoli, Vittorino. 2008. Il matto di carta: La follia nella letteratura. Milan: Biblioteca Universale Rizzoli.

Basaglia, Franco. (1964) 2017. La distruzione dell'ospedale psichiatrico come luogo di istituzionalizzazione. In Basaglia, Franco. Scritti 1953-1980, 261-270. Milan: ilSaggiatore.

- (1967) 2017. La soluzione finale. In Basaglia, Franco. Scritti 1953-1980, 443-450. Milan: ilSaggiatore.

—. (1975) 2017. Crimini di pace. In Basaglia, Franco. Scritti 1953-1980, 707-790. Milan: ilSaggiatore.

- 2000. Conferenze Brasiliane. Milan: Raffaello Cortina.

- 2012. Intervista a Franco Basaglia. In Cronaca di una liberazione: Da matti a cittadini d'Europa, ed. Luigi Attenasio et al., 70-71. Rome: Armando Editore.

Battistini, Francesco. 2018. Alberta Basaglia: "I dubbi sulla legge? Dove è stata applicata ha funzionato". Corriere della Sera, April 30. https://www.corriere. it/buone-notizie/18_aprile_30/alberta-basaglia-dubbi-legge-dove-stataapplicata-ha-funzionato-c7 lf4b28-4c83-11e8-99ac-c9986d6134ff. shtml?refresh_ce-cp

Bresciani Califano, Mimma. 2011. Tobino: Il recupero della follia a dignità dell'esistenza. In Piccole zone di simmetria: Scrittori del Novecento, 61-74. Florence: Firenze University Press. 
Brown, Julie Vail. 1986. Female Sexuality and Madness in Russian Culture: Traditional Values and Psychiatric Theory. Social Research 53 (2): 369-385.

Castelli, Lorenzo. 1978. Da Pisa Franco Basaglia replica a Tobino: I manicomi esistono, ma possono essere distrutti. Paese Sera, May 4.

Colucci, Mario. 2011. Lo scandalo Basaglia. In Franco Basaglia: Un laboratorio italiano, ed. Federico Leoni, 21-33. Milan: Bruno Mondadori.

De Vecchis, Primo. 2010. Tobino medico di manicomio attraverso il Diario. In La sabbia e il marmo: La Toscana di Mario Tobino, ed. Giulio Ferroni, 171-184. Rome: Donzelli Editore.

- 2012. Tobino, Basaglia e la legge 180: Storia di una polemica. In Il turbamento e la scrittura, ed. Giulio Ferroni, 171-188. Rome: Donzelli Editore.

Del Beccaro, Felice. 1967. Tobino. Milan: Il Castoro.

Foot, John. 2015. The Man Who Closed the Asylums: Franco Basaglia and the Revolution in Mental Health Care. New York/London: Verso.

Freud, Sigmund. 1962. Three Essays on the Theory of Sexuality. Trans. James Strachey. New York: Avon.

Goffman, Erving. 2007. Asylums: Essays on the Social Situation of Mental Patients and Other Inmates. New Brunswick: Transaction.

Maggiorelli, Simona. 2010. Riaprono le stanze di Tobino a Maggiano. https:// simonamaggiorelli.com/2010/05/10/riaprono-le-stanze-di-tobino-a-maggiano/. Accessed 31 Aug 2018.

Marabini, Claudio. 1969. Tobino. In Gli anni sessanta, narrativa e storia, ed. Claudio Marabini, 239-258. Milan: Rizzoli.

Martinucci, Silvia. 1995. Gli "umani documenti" della follia: Lettura de Le libere donne di Magliano di Mario Tobino. Dissertation, University of Florence.

Mulvey, Laura. 1999. Visual Pleasure and Narrative Cinema. In Film Theory and Criticism: Introductory Readings, ed. Leo Braudy and Marshall Cohen, 833-844. Oxford: Oxford University Press.

Sforza Tarabochia, Alvise. 2013. Psychiatry, Subjectivity, Community: Franco Basaglia and Biopolitics. Bern/Oxford: Peter Lang.

Szasz, Thomas Stephen. 1960. The Myth of Mental Illness. American Psychologist 15: 113-118.

Tobino, Mario. 1972. Per le antiche scale. Milan: Mondadori.

- 1990. Il manicomio di Pechino. Milan: Mondadori.

- 1992. Una vacanza romana. Milan: Mondadori.

—. (1982) 2009. Gli ultimi giorni di Magliano. Milan: Mondadori.

_. (1953) 2012. Le libere donne di Magliano. Milan: Mondadori. Adobe Digital Editions.

Tumiatti, Corrado. 1931. Tetti rossi. Milan: Treves.

Zappella, Michele. 2010. Mario Tobino e i novatori. In Il turbamento e la scrittura, ed. Giulio Ferroni, 189-192. Rome: Donzelli Editore. 


\section{INDEX $^{1}$}

A

Antonioni, Michelangelo, 17

Autunno caldo, see Hot autumn

B

Basaglia, Franco, 21-27, 30, 35n6, $44,45,69,128 \mathrm{n} 3,147$, 195, 197, 199, 200, 211-217, $219,220,226 \mathrm{n} 2,230-235$, $242 \mathrm{n} 3$

Basaglia's law/Basaglia law, see Law $180 / 1978$

C

Calvino, Italo, 13, 68, 69, 91, 128n2, $195,198,201$

Communism/Communist

Party, 5, 139
D

De Andrè, Fabrizio, 18

Depersonalization, 28, 61, 97, 103, $108,142-144$

Disney, 31
$\mathrm{E}$

Economic boom, see Economic miracle Economic miracle, 4, 7, 10, 13, $16,45,80,112 \mathrm{n} 2,140-144$, 149,150

Entfremdung, 3, 100, 103, 143

F

Fascism, 20, 46, 53, 64, 137, 138, $140,234,243 n 9$

Feminism, 157-159

Ferenczi, Sandor, 159-160, 164, 170n5

${ }^{1}$ Note: Page numbers followed by ' $n$ ' refer to notes.

(C) The Author(s) 2019

A. Diazzi, A. S. Tarabochia (eds.), The Years of Alienation in Italy, https://doi.org/10.1007/978-3-030-15150-8 
Fiat, 17

Franchi Narratori, 17, 30, 198

Freud, Sigmund, 57n18, 100, 101, $104,136,137,140,143,157$, 159-164, 175, 176, 179, 186n7, $200,207,240$

G

Gaber, Giorgio, 32

Goffman, Erving, 24, 44, 45, 52, 197, 218,232

$\mathrm{H}$

Hegel, Georg Wilhelm Friedrich, 98-100, 165

Heidegger, Martin, 98, 215, 217

Hot autumn, 6, 17, 18

I

Industrial literature, 9, 10, 13, 17, 28, 115,147

L

Lacan, Jacques, 160-162, 164, 170nl, 170n5, 174-180, 183-184, $185 \mathrm{n} 5,186 \mathrm{n} 6,215$

Law 36/1904, 20, 22, 44, 45, 50, $55 \mathrm{n} 2,57 \mathrm{n} 17,242 \mathrm{n} 2$

Law 180/1978, 22, 23, 27, 33, 44-46, 52, 53, 69, 226, 230, $242,242 \mathrm{n} 2-4,243 \mathrm{n} 12$

Legge Basaglia, see Law 180/1978

Literature of the factory, see Industrial literature
M

Marx, Karl, 3, 8, 98, 100, 101, 112n2, $175,185 \mathrm{n} 5$

Marxism, 2, 7, 24, 47, 72, 88, 136, $139,143,149,158$

Miracolo economico, see Economic miracle

O

Olivetti (factory), 80, 81, 99, 112n3, $119,120,148-150,15 \ln 2$

Olivetti, Adriano, 7, 14, 35n2, 79-86, 88-94, 112n3, 119, 120, 144, 146

Operaismo, 5
$\mathbf{P}$

Partito Comunista Italiano (PCI), 5, 80, 138

Pasolini, Pier Paolo, 4, 33, 35n3, 45, $62,64,93,113 \mathrm{n} 8,125$

$S$

Sartre, Jean-Paul, 24-26, 98, 166, $167,213-214$

$\mathrm{T}$

Tafuri, Manfredo, 45-48, 50, 52

V

Verfremdung, 15, 100

Y

Years of lead, 45, 62 